\title{
Dace Žentiṇa
}

\section{Bioķimisko un onkoloğisko marķieru diagnostiskā nozīme malignu pleiras eksudātu diferencēšanā no citas etioloğijas šḳidruma pleiras dobumā}

Promocijas darbs zinātniskā doktora grāda "zinātnes doktors (Ph.D.)" iegūšanai

Nozare - medicina Apakšnozare - pneimonoloğija

$$
\text { Rīga, } 2020
$$




\title{
RĪGAS STRADINA
UNIVERSITĀTE
}

Dace Žentiņa

ORCID 0000-0002-5148-7010

\section{Bioķīmisko un onkoloğisko marḳieru diagnostiskā nozīme malignu pleiras eksudātu diferencēšanā no citas etiolog̣ijas šķidruma pleiras dobumā}

\author{
Promocijas darbs zinātniskā doktora grāda \\ "zinātnes doktors (Ph.D.)" iegūšanai
}

\author{
Nozare - medicīna \\ Apakšnozare - pneimonologiija \\ Darba zinātniskie vadītāji:
}

Dr. med., LZA īstenais loceklis, profesors Aivars Lejnieks

Dr. med. asociētais profesors Alvils Krams 


\begin{abstract}
ANOTĀCIJA
Šķidrums pleiras dobumā ir bieža dažādu slimību komplikācija. Atkarībā no patoǵenētiskā mehānisma šķidrumus iedala transudātos un eksudātos. Biežākais transudāta cēlonis ir sirds mazspēja. Biežākie eksudātu veidi ir parapneimonisks pleirīts un maligns pleiras eksudāts. Dažādas etiologijias šķidrumu pleiras dobumā ārstēšana un prognoze būtiski atšķiras, tāpēc ir svarīga precīza diagnoze. Maligna pleiras eksudāta (MPE) diagnostika ne vienmēr ir vienkārša, tāpēc joprojām tiek meklēti papildu diagnostiskie marḳieri.

Darba teorētiskajā daḷā tika apkopoti un analizēti literatūras dati par šķidruma pleiras dobumā epidemiolog̣iju, diagnostiku un ārstēšanu. Oriǵinālā pētījuma mērkisis bija noskaidrot, vai iespējams uzlabot malignu pleiras eksudātu diagnostiku, izmantojot onkologiskos vai bioķīmiskos marķierus.

Lai noskaidrotu esošo situāciju un problēmas aktualitāti, retrospektīvi tika analizētas to pacientu medicīniskās kartes, kuri no 2010. gada 1. janvāra līdz 2010. gada 31. decembrim ārstējušies un izrakstīti no Rīgas Austrumu Klīniskās universitātes slimnīcas stacionāra “Gaiḷezers” iekšķ̣̄go slimību profila nodaḷām vai šajā slimnīcā miruši. Tika atlasītas un analizētas tās medicīniskās kartes, kurās izrakstǐšanās diagnozē bija norādes par šḳidrumu pleiras dobumā.

Lai noskaidrotu papildu bioķīmisko un onkoloǵisko marķieru nozīmi maligna pleiras eksudāta (MPE) diagnostikā, prospektīvi tika analizēti no 2011. gada 8. augusta līdz 2014. gada 13. jūnijam Rīgas Austrumu klīniskās universitātes slimnīcas stacionāra "Gaiḷezers" Iekšḳīgo slimību klīnikas Pulmonoloǵijas nodạ̣ā secīgi stacionēti pacienti ar šķidrumu pleiras dobumā. Papildus rutīnas izmeklējumiem šiem pacientiem pleiras šķidrumā un serumā tika noteikti B tipa nātrijurētiskais faktors (BNP), plazminogēna aktivatora inhibitors 1 (PAI-1), karcinoembrionālais antigēns (CEA) un vēža karbohidrāta antigēns 125 (CA 125).

Retrospektīvi analizējot medicīniskās dokumentācijas datus, tika konstatēts, ka 741 $(4,6 \%)$ pacientam no gada laikā stacionārā "Gaiḷezers" ārstētiem, izrakstītiem vai mirušiem pacientiem diagnozē minēts šķidrums pleiras dobumā. $47 \%$ no tiem diagnosticēts maligns pleiras eksudāts, $29 \%$ - kardiāls hidrotorakss un $19 \%$ - parapneimonisks pleirīts. Mirstība pacientiem ar šḳidrumu pleiras dobumā bija 3 reizes augstāka nekā visiem ārstētajiem pacientiem kopā (attiecīgi 14,1\% un 4,4\%). Tika konstatēts, ka aplūkotajā laika posmā izmeklēšanas metodes pacientiem ar šḳidrumu pleiras dobumā bija nepietiekamas, salīdzinot ar medicīnas literatūrā rekomendētajām.
\end{abstract}


Prospektīvi tika analizēti 144 pacienti ar šķidrumu pleiras dobumā. Tika konstatēts, ka CA 125 pacientiem ar malignu pleiras eksudātu ir statistiski ticami augstāks gan pleiras punktātā, gan serumā. Tas liecina, ka CA 125 var kalpot kā papildu marḳieris malignu pleiras eksudātu diagnostikā.

Būtiska nozīme dažādu pleiras šḳidrumu patoǵenēzē ir fibrinolītiskajai sistēmai. Parapneimonisku pleirītu gadījumā fibrinolīze ir kavēta un veidojas norobežotas šḳidruma kolekcijas, savukārt malignu pleiras erksudātu gadījumā parasti norobežošanās nenotiek. Iespējams, ietekmējot fibrinolītisko sistēmu, varētu uzlabot dažādas etiologijas pleiras eksudātu ārstēšanu. Tāpēc darbā pētīts viens no fibrinolīiskās sistēmas markiieriem - protrombīna aktivētāja inhibitors 1 (PAI-1). Tika konstatēts, ka PAI-1 līmenis malignos pleiras eksudātos bija statistiski ticami zemāks nekā parapneimonisku pleirītu gadījumā. Tas var liecināt par procesa tendenci izplatīties ḷaundabīgu slimību gadījumā pretēji parapneimonisku pleirītu tendencei norobežoties ar fibrīna septām.

Darbā konstatēts, ka kardiāla hidrotoraksa diferencēšanai informatīvs marḳieris ir BNP asins serumā, taču BNP pleiras punktātā papildu diagnostisku informāciju nesniedz. 


\section{SUMMARY}

Pleural effusion is a frequent complication of different diseases. Depending on pathogenetic mechanism, the effusion is divided into transudates and exudates. The most often cause of transudate is cardiac failure. The most frequent forms of exudates are parapneumonic pleuritis and malignant pleural effusion (MPE). Treatment and prognosis in pleural effusion of different etiology is different so definitive diagnose is very important. Diagnostics of malignant pleural effusion is not always simple, so additional diagnostics markers are still searched for.

The theoretical part of the doctoral thesis summarizes and analyses the literature data in epidemiology, diagnostics and treatment of pleural effusion. The aim of the original study was to find out whether it is possible to improve the diagnostics of malignant pleural effusion by using of tumor or biochemical markers.

To clarify the current situation and significance of the poblem, patients diagnosed with pleural effusion from 01.01.2010 to 31.12.2010 at Internal Diseses Departments of Riga East University Hospital were retrospectively reviewed.

To find out the importance of additional biochemical and tumor markers in the diagnostics of MPE, patients with pleural effusion sequentially stationed from 08.08.2011 to 13.06.2014 in the Pulmonology Department of Internal Diseases Clinic of Riga East Clinical University Hospital "Gailezers" were prospectively analysed. In addition to routine examinations, B type natriuretic peptide (BNP), plasminogen activator inhibitor - 1 (PAI-1), carcinoembryonic antigen (CEA) and cancer carbohydrate antigen 125 (CA 125) levels in the pleural effusion and serum were analysed.

Pleural effusion was diagnosed in $741(4.6 \%)$ of retrospectively analysed patients. $47 \%$ of them were diagnosed with MPE, 29\% - with cardiac hydrothorax and 19\% - with parapneumonic pleuritis. The mortality rate of patients with pleural effusion was 3 times higher than mortality rate of all treated patients total ( $14.1 \%$ and $4.4 \%$ respectively). It was established that the examination methods for patients with pleural effusion were insufficient during the analysed period.

144 patients with pleural effusion were analysed prospectively. It was established that CA 125 level in patients with MPE is statistically higher both in pleural effusion and in serum hence CA 125 can serve as additional marker in diagnostics of MPE.

Fibrinolytic system has significant role in pathogenesis of different pleural effusions. In case of parapneumonic pleuritis, fibrinolysis is delayed and loculated effusions occur, but in case of MPE loculation commonly doesn't appear. Probably the treatment of pleural effusion of 
different etiology could be improved by influencing the fibrinolytic system. It was established that the level of PAI-1 in malignant pleural effusion was statistically significant lower that in case of parapneumonic pleuritis. This may indicate the trend of process spread in case of malignant diseases unlike the trend to loculate in case of parapneumonic pleuritis.

An informative marker of cardiac hydrothorax is BNP in serum, but BNP in pleural effusion doesn't provide any additional diagnostic information. 


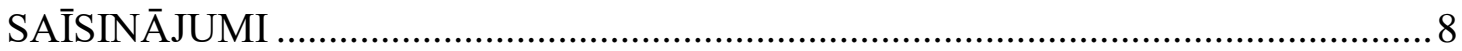

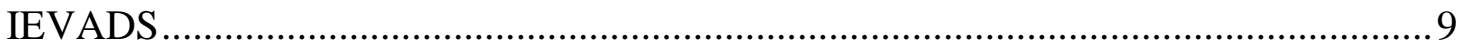

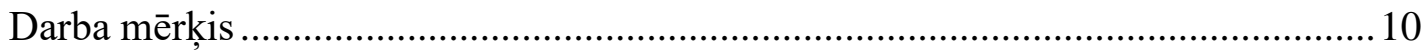

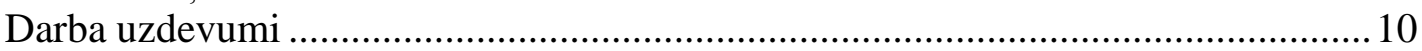

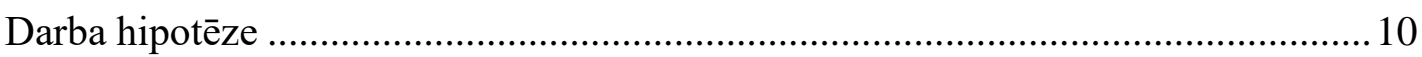

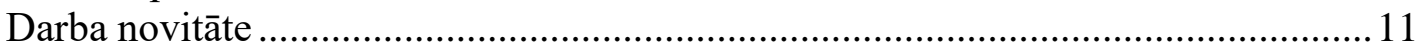

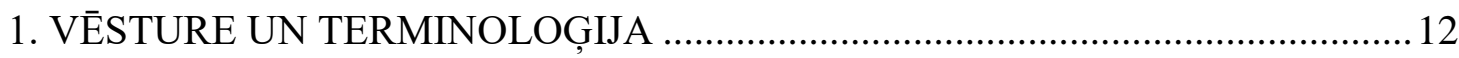

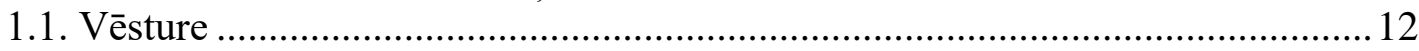

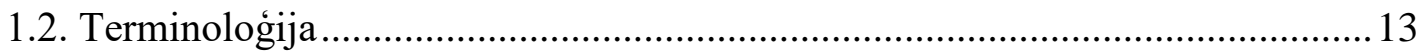

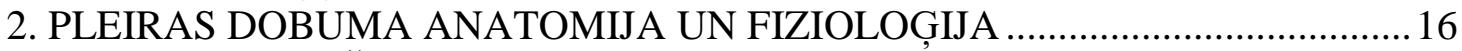

3. PATOLOG̣ISKS ŠĶIDRUMS PLEIRAS DOBUMÁA …........................................ 19

3.1. Pleiras patoloğijas epidemiologija un incidence ............................................. 21

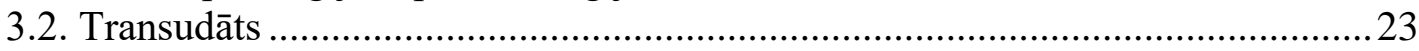

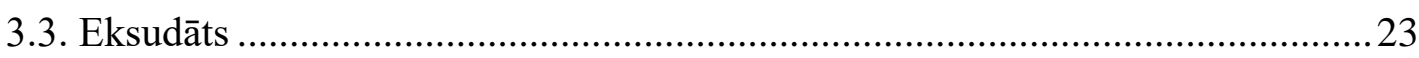

3.3.1. Pleiras dobuma infekcija, parapneimonisks pleirīts un pleiras empiēma.... 23

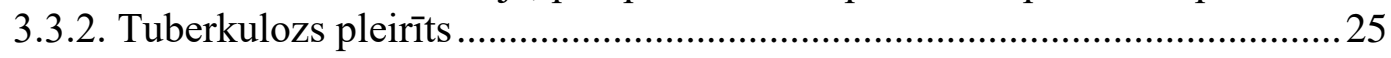

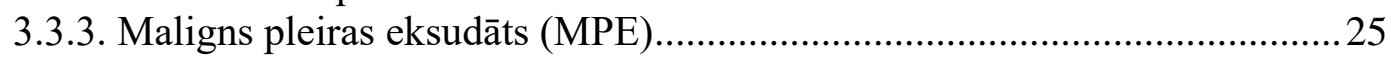

3.3.4. Pleiras eksudāts plaušu artērijas trombembolijas (PATE) gadījumā ...........27

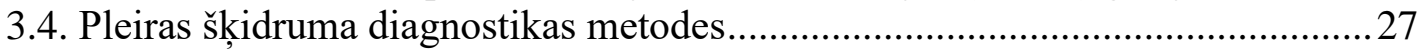

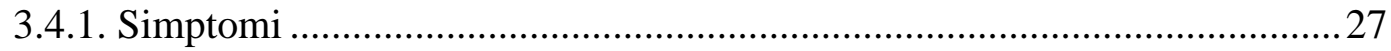

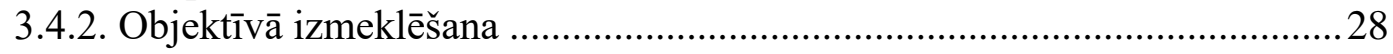

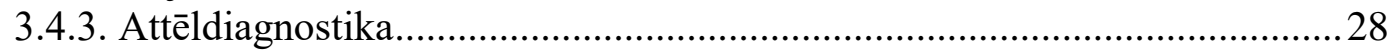

3.4.4. Invazīvas pleiras dobuma izmeklēšanas metodes .................................... 30

3.4.5. Laboratoras pleiras šķidruma izmeklēšanas metodes ................................ 34

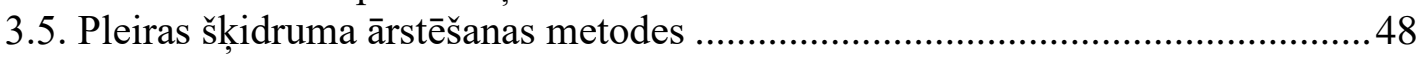

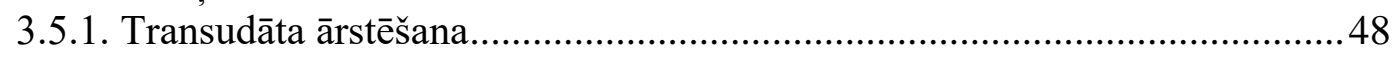

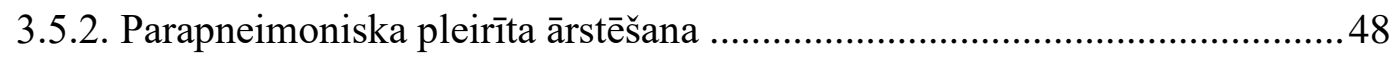

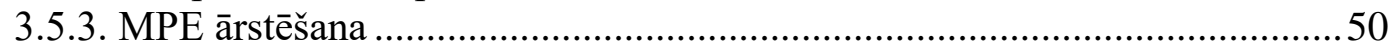

3.6. Maligna pleiras eksudāta aktualitāte no veselības aprūpes sistēmas viedokḷa...54

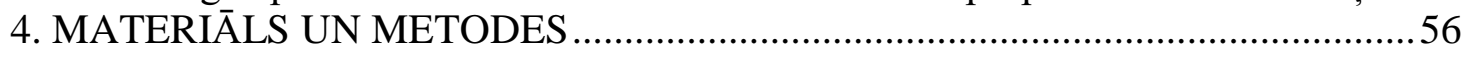

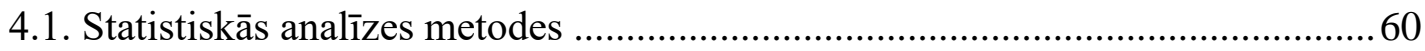

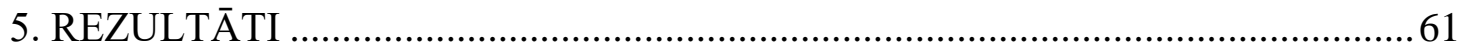

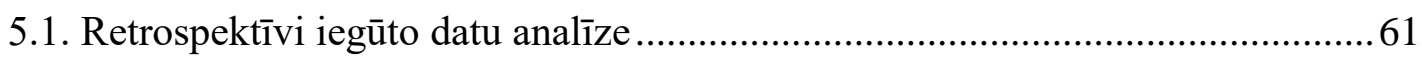

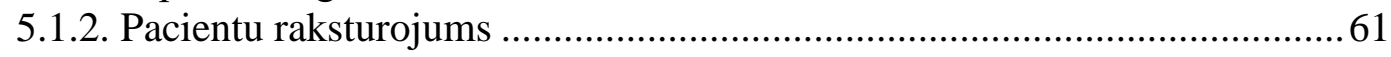

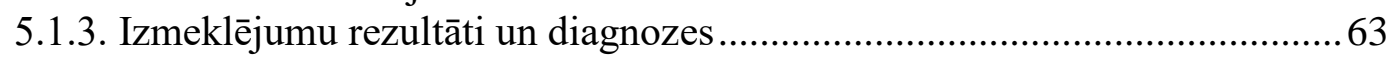

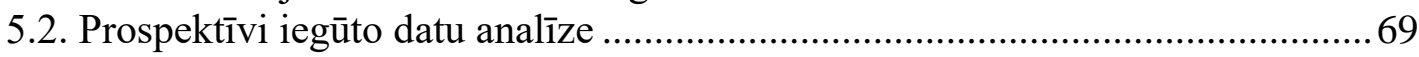

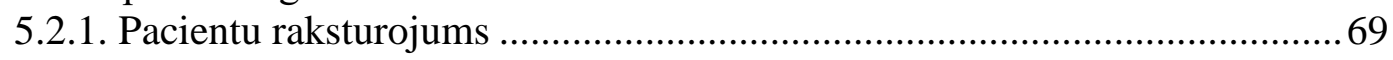

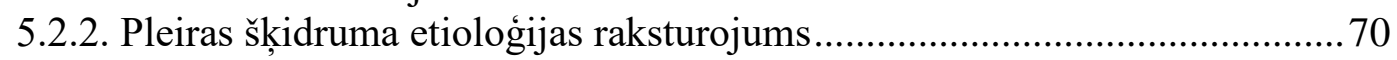

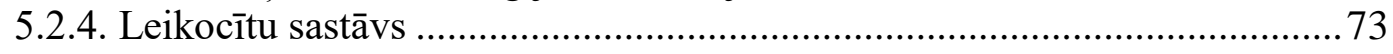

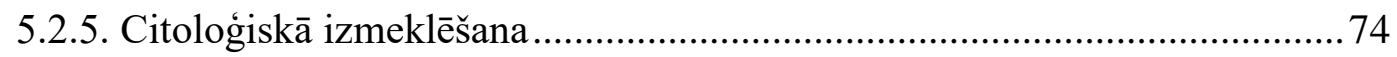

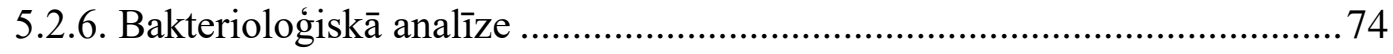

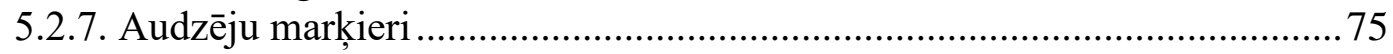

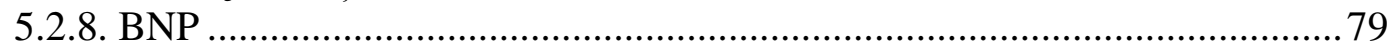

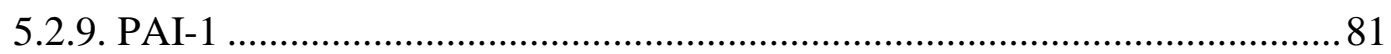

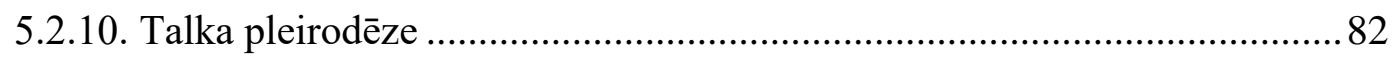

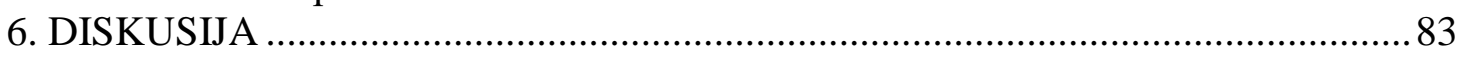




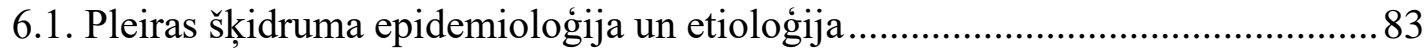

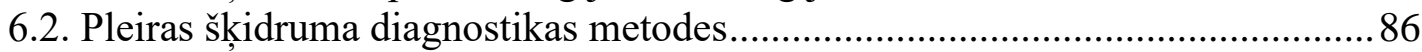

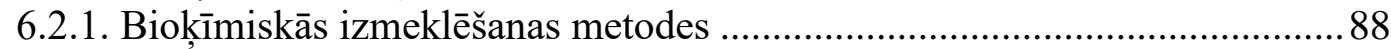

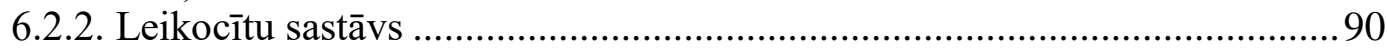

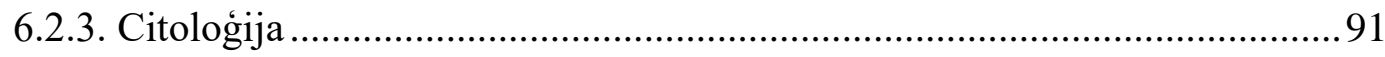

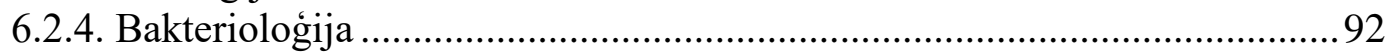

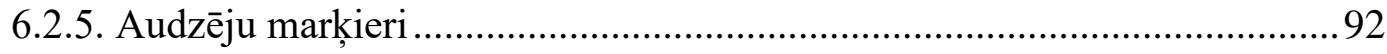

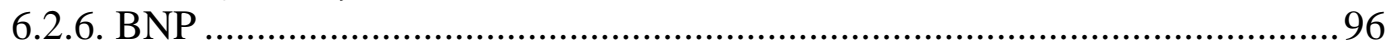

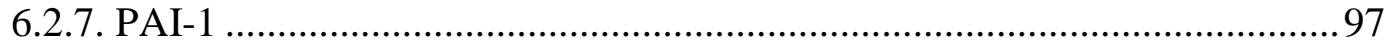

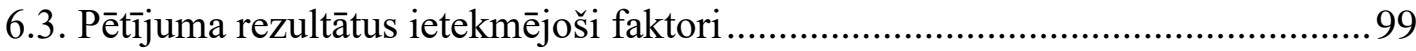

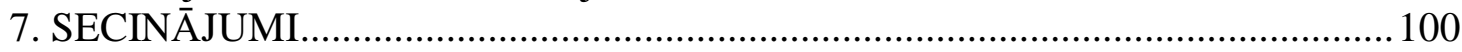

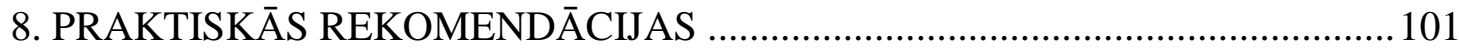

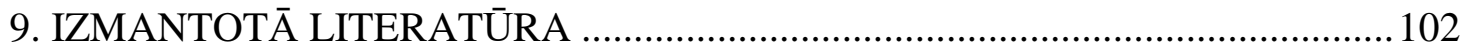

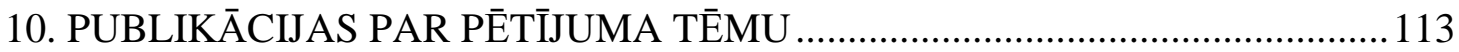

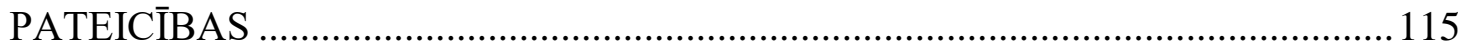

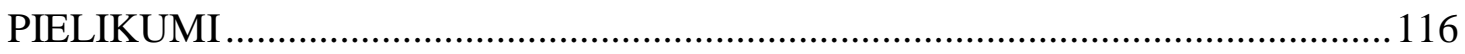




\section{SAĪSINĀJUMI}

ADA adenozīndezamināze

BNP smadzeṇu nātrijurētiskais peptīds (angl. brain natriuretic peptide)

CA 125 vēža karbohidrāta antigēns 125

CA 19-9 vēža karbohidrāta antigēns 19-9

CA 15-3 vēža karbohidrāta antigēns 15-3

CEA karcinoembrionālais antigēns

DT datortomogrāfija

HU Hounsfilda vienības

LDH laktātdehidrogenāze

MPE maligns pleiras eksudāts

MMN monomorfas nukleārās šūnas

NT-proBNP N termināla pro-nātrijurētiskais peptīds (angl. $N$-terminal pro-brain natriuretic peptide)

NT-proBNP N termināla pro-nātrijurētiskais peptīds (angl. $N$-terminal pro-brain natriuretic peptide)

PAI1 plazminogēna aktivatora inhibitors 1

PATE plaušu artērijas trombembolija

PET pozitronu emisijas tomogrāfija

PMN polimorfonukleārās šūnas

RAKUS Rīgas Austrumu klīniskā universitātes slimnīca

ROC līkne receiving operating characteristics līkne

US ultrasonogrāfija

VATS videoasistēta torakoskopija 


\section{IEVADS}

Pleiras eksudāts - saturs pleiras dobumā, kas rodas iekaisuma, malignu šūnu proliferācijas un/vai patologiiski izmainītas kapilāru caurlaid̄̄bas dēḷ, - ir bieža dažādu slimību komplikācija. Tā iemesli galvenokārt ir ļaundabīgi audzēji, pneimonija un tuberkuloze. Kaut gan plaši epidemioloǵiskie pētījumi nav pieejami, tomēr pēc literatūras datiem var spriest, ka visbiežākie cēloṇi tam, ka pleiras dobumā krājas šḳidrums, ir kardiāls hidrotorakss un maligns pleiras eksudāts, bet trešais biežākais iemesls ir parapneimonisks pleirīts (Marel et al., 1993; Zablockis et al., 2002; Valdes et al., 1996; Broadus et al., 2016). Dažādas etioloǵijas pleiras šķidrumu ārstēšana un prognoze būtiski atšķiras, tāpēc ir svarīgi katrā gadījumā precizēt etiologiju. Kardiāla hidrotoraksa diagnostika klīniskajā praksē grūtības parasti nesagādā, bet malignu pleiras eksudātu (MPE) diagnosticēt var būt sarežğīti, īpaši tādēḷ, ka ne visur ir pieejama torakoskopija patologiisko audu materiāla iegūšanai un tālākai histologisiskai analīzei. Tāpēc ne tikai pasaulē, bet arī Latvijā ir svarīgi meklēt citus pieejamus, relatīvi lētus marḳierus šo pleiras eksudātu diagnostikai.

Visbiežāk ar malignu eksudātu komplicējas plaušu vēzis vīriešiem un krūts vēzis sievietēm (Roberts et al., 2010). Latvijā precīzu datu par malignu pleiras eksudātu biežumu nav, bet pēc Slimību profilakses un kontroles centra datiem 2015. gadā reǵistrēti 11123 pacienti ar no jauna diagnosticētu vēzi, no kuriem 1001 konstatēts plaušu un bronhu vēzis un 1167 - krūts vēzis (Veselības ministrijas slimību profilakses un kontroles centrs, 2015). Plaušu slimību speciālistu klīniskajā praksē maligni pleiras eksudāti ir bieži sastopama un ne vienmēr viegli risināma problēma. Šobrīd pasaulē nav daudz rekomendāciju, kā rīkoties pleiras šķidruma gadījumā, - pēdējās ir 2014. gada spāṇu vadlīnijas 2014. gada (Villena Garrido et al., 2014) un 2010. gada Britu torakālās asociācijas publicētās vadlīnijas, ko izstrādājusi Pleiras slimību vadlīniju grupa (Du Rand I., Hooper C., MuccDuff A., Roberts M. E., Davies H. E., Rahman N. M., Havelock T. et al., 2010). Latvijā vadlīnijas nav izstrādātas un, kaut arī ar šādu patologiju ikdienas praksē var saskarties ikviens ārsts, kas strādā slimnīcā un arī ambulatorā praksēe šī tēma dažādos tālākizglītības pasākumos tiek aktualizēta reti. Konvencionālās metodes - pleiras dobuma satura klīniska, bioķīmiska un citoloǵiska izmeklēšana - ne vienmēr ir pietiekami informatīvas, lai ātri un ticami precizētu pleiras eksudāta etioloğiju un izvēelētos turpmākās diagnostiskas un ārstēšanas metodes, tāpēc Eiropas Respiratorās savienības (European Respiratory Society) un Amerikas Torakālās asociācijas (American Thoracic Society) 2001. gada ziņojumā par malignu pleiras eksudātu ārstēšanas taktiku kā viens no izpētes virzieniem šajā jomā tiek rekomendēta jaunu maligna eksudāta marķieru identifikācija 
(Antony et al., 2001). Pleiras eksudāta diferenciāldiagnostikā tiek piedāvātas citas bioloǵiski aktīvas vielas - interferons gamma, interleikīns 6, vaskulārais endotēlija augšanas faktors, tumora nekrozes faktors alfa u. c. (Daniil et al., 2007; Thomas et al., 2016; Fafliora et al., 2016; Li et al., 2016), bet pagaidām nav noskaidrota intrapleirālās fibrinolītiskās sistēmas aktivitāte (Philip-Joet et al, 1995; Chung et al., 2003). Zināms, ka fibrinolītiskās sistēmas aktivitāte plazmā ir saistīta ar iekaisuma aktivitāti, turklāt plazminogēna inhibitora 1 (PAI-1) aktivitāte malignos eksudātos varētu būt augstāka nekā iekaisīga rakstura eksudātos (Chung et al., 2003). Ir pētījumi par audzēju markịieru CA 125 un CEA koncentrāciju pleiras eksudātā un to atkarību no audzēja histoloǵiskā tipa. N̦emot vērā visu iepriekš minēto, promocijas darbā meklēta atbilde uz jautājumiem, vai ar papildu bioḳīmisko un onkoloǵisko marḳieru palīdzību varētu uzlabot MPE diagnostiku.

\section{Darba mērḳis}

Noskaidrot, vai, izmantojot papildu bioḳīmiskos un onkologiskos marḳierus, ir iespējams uzlabot malignu pleiras eksudātu diagnostiku.

\section{Darba uzdevumi}

1. Izanalizēt pieejamo literatūru par šķidrumu pleiras dobumā, tā diagnostiku un diferenciāldiagnostiku.

2. Noskaidrot dažādas etioloǵijas pleiras šķidruma, tostarp malignu pleiras eksudātu, pacientu skaitu SIA RAKUS “Gaiḷezers” iekšķı̄go slimību nodaḷās viena gada laikā.

3. Izpētīt klīniskajā praksē lietotās pleiras eksudātu diagnostiskas metodes.

4. Noskaidrot, vai, izmantojot papildu bioḳīmiskos (PAI-1, BNP) un onkologiskos (CEA un CA 125) marḳierus, palielinās pleiras punktāta laboratoro izmeklēšanas metožu jutība malignu pleiras eksudātu diferencēšanā.

5. Formulēt rekomendācijas šķidruma pleiras dobumā diagnostikai.

\section{Darba hipotēze}

Papildus nosakot bioḳīmisko un onkoloǵisko marḳieru koncentrāciju pleiras dobuma šķidrumā, var būtiski uzlabot malignu pleiras eksudātu diferencēšanu no citas etioloǵijas šķidruma pleiras dobumā. 


\section{Darba novitāte}

Līdz šim dati par pacientiem, kam stacionārā konstatēta pleiras patoloǵija, analizēti reti. Darbā pētīta fibrinolītisko parametru (PAI-1) un audzēja marķieru koncentrācijas serumā un pleiras eksudātā līdz šim neskaidrā nozīme pleiras patoloǵijas diagnostikas un ārstēšanas algoritmā. 


\section{VĒSTURE UN TERMINOLOĢIJA}

\subsection{Vēsture}

Ļoti ilgi pleira kā anatomiska vienība nebija pazīstama. Senajiem grieķiem vārds pleuron apzīmēja sānu, bet to parasti neattiecināja uz cilvēkiem, bet gan lietoja mitoloǵijā, zoologijāà, ǵeometrijā un botānikā.

Pirmais membrānas jēdzienu ieviesa Aristotelis (384-322. g. p. m. ē.), kurš rakstīja, ka visiem dzīvniekiem, kuriem ir asinis, ir arī membrānas, kas aptver gan kaulus, gan orgānus. Līdzīgi domāja Erasistratus (310-250. g. p. m. è.) no Aleksandrijas skolas, kurš atšḳīa slimību, kas skar plaušu, no slimības, kas skar hymen hypezocota, kas apṇem plaušu. Galēns (120.-200. g. m. ē.) turpināja šo uzskatu, aprakstot membrana succingens, kas pārklāj krūšu kurvja orgānus līdzīgi kā vēdera dobuma orgānus pārklāj peritonejs. Viņš uzskatīja, ka š̄̄ membrāna ir paredzēta plaušu aizsardzībai no berzēšanās pret ribām elpošanas laikā. Tikai renesanses laikā, kad plaši tika veiktas autopsijas, Mondino de Liuzzi (1274.-1326.) pleiras dobumu aprakstīja samērā precīzi, turklāt piebilstot, ka pleiras dobums aizkavē tajā radušos strutu izplatīšanos uz citiem orgāniem un membrānā, kas izklāj krūšu kurvja dobumu, ir daudz nervu struktūru, tāpēc tā ir ḷoti jutīga un iekaisuma rezultātā cilvēkam ir stipras sāpes. Vistuvāk mūsdienu priekšstatam par pleiras dobumu nonāca Fracois Xavier Bichat (1771.-1802.), kurš aprakstīja ne tikai pleiras pārklājošo funkciju, bet arī konstatēja, ka pleira pastāvīgi izdala un reabsorbē serozu šķidrumu, turklāt piedalās orgānu kustības nodrošināšanā (Tassi et al., 2008).

Pirmā pleiras slimība, kas tika aprakstīta, ir pleirīts. Hiopkrāts Aforismos (400. g. p. m. è.) to piemin kā slimību, kuras simptomi ir klepus, sāpes sānā, ortopnoe un drudzis. Pēc Hipokrāta vārdiem, pleirīts, kas neizzūd 14 dienās, kḷūst par empiēmu. Empiēmas ārstēšanā Hipokrāts ieteica empiēmas drenēšanu caur muti, izraisot vemšanu, vai arī caur taisno zarnu, izraisot caureju, tomēr viņš arī pirmais aprakstījis atvērto drenāžu, kad jāizdara slīps grieziens zemākajā interkostālajā spraugā un jāperforē riba vai jāizṇem tās fragments, lai strutas varētu drenēties uz āru. Prognozi Hipokrāts novērtēja pēc šķidruma, kas izdalās - ja tās ir strutas, tad pacients dzīvos, bet, ja strutas ir sajauktas ar asinīm, gḷotām un ir smirdošas, cilvēks mirs. Mirstība no pleiras infekcijas tiešām bija ḷoti augsta: tiek lēsts, ka no 400 g. p. m. ē. līdz 1500 g. m. è. tā sasniedza $80 \%$, līdz pat 1900. gadam mirstība bija $50 \%$ gadījumu, savukārt līdz 1950. gadam mirstība bija $30 \%$ gadījumu un tikai pēc tam pakāpeniski samazinājās līdz mūsdienu līmenim (Tassi et al., 2008).

Pleiras audzēji rakstos pirmo reizi minēti 1767. gadā (Joseph Lietaud), savukārt Laennec 1819. gadā publicēja darbu L'Auscultation Mediate, kurā pirmo reizi pleirītu iedalīja 
akūtā un hroniskā. Damuazo (Damoiseau) 1828. gadā un Eliss (Ellis) 1874. gadā aprakstīja, ka perkutoram pieslāpējumam ir lokveida robeža, ko mēs joprojām pazīstam kā Elisa-Damuazo līniju. Pamatus mūsdienu izpratnei par pleiras punkciju lika Bostonas iekšķīgo slimību ārsts Henry Bowditch, kurš 1852. gadā publicēja rezultātus par 65 viṇa veiktajām paracentēzēm, pamatojot, ka punkcija ir viegli veicama invaziva procedūra un nav jāuzskata par ekstrēmi bīstamu manipulāciju, kā tika uzskatīts 2 gadu tūkstošus pirms viṇa. 1882. gadā Ehrlic pirmo reizi konstatēja l̦aundabīgas šūnas pleiras punktātā. Pirmo torakoskopiju Samuel Gordon aprakstīja 1866. gadā, tomēr sistemātiski torakoskopiju pleiras patologiijas gadījumos sāka izmantot Hans Christian Jacobaeus 1910. gadā, bet pirmo torakoskopijas laikā diagnosticēto mezoteliomas gadījumu aprakstīja tikai 1939. gadā Sergent un Kaurilsky. Zemūdens drenāžas sistēmas ieviesa 19. gadsimtā - 1877. gadā, kad Gothards Bīlavs (Gotthard Bülau) to sāka izmantot empiēmas drenāžai. Zemūdens drenāžas sistēmas līdz šai dienai dažkārt dēvē par Bīlava sistēmām (Tassi et al., 2008).

L,oti strauji pleiras dobuma slimību ārstēšana sāka attīstîties 20. gadsimta otrajā pusē, attīstoties antibakteriālai terapijai un dažādām invazīvām manipulācijām.

\subsection{Terminoloğija}

Latviešu valodā dažādu zinātnē izmantojamo terminu lietošanu nosaka Latvijas Zinātṇu akadēmijas terminolog̣ijas komisija, kuras Medicīnas Terminologijas apakškomisiju vada profesors Māris Baltiņš un kura nodarbojas ar medicīnas terminiem latviešu valodā. Termini tiek publicēti brīvpieejas Akadēmiskā Terminu datubāzē AkadTerm. Saistībā ar vārda sakni "pleir-” šajā datubāzē atrodami divi šķirkḷi - "pleira” un "pleiras bojājums”, bet pleiras slimību termini pagaidām šeit nav atrodami.

Kristapa Rudzī̌sa Terminologia Medica (Rudzītis, 2005.) latīṇu termins Pleuritis tulkots kā pleirīts ar skaidrojumu "pleiras iekaisums", turpat sīkāk izšķirot pleuritis adhesivaadhezīvais pleirīts, kad veidojas saaugumi starp plaušu un parietālo pleiru; pleuritis cholesterinica - eksudatīvais pleirīts, kura šķidrumā ir holesterīns; pleuritis chylosa - hilozais pleirīts; pleuritis circumscripta - norobežotais pleirīts; pleuritis costalis - krūšu plēves iekaisums, pleuritis diffusa - pleirīts, kas skar visu pleiru; pleuritis exudativa, sinonīms humida, serofibrinosa - eksudatīvais jeb slapjais pleirīts, kas rada serofibrinoza šķidruma uzkrāšanos pleiras dobumā, tā cēlonis visbiežāk ir tuberkuloze vai akūts reimatisms; pleuritis fibrinosa sausais pleirīts ar fibrinoziem aplikumiem uz pleiras, pleuritis haemorrhagica - eksudatīvais pleirīts ar asiņainu šķidrumu, pleuritis metapneumonica - pleirīts, kas radies pēc pneimonijas, 
pleuritis parapneumonica - pleirīts, kas radies pneimonijas laikā, pleuritis purulenta vai pleuritis suppurativa, sinonīms empyema pleurae, pleuritis seroza - pleirīts ar serozu eksudātu.

Šķirklim Hydrothorax (sinonīms hydrops pleurae) tulkojums ir hidrotorakss, serozs šķidrums pleiras dobumā. Šķirklim Hydrops tulkojums ir ūdenssērga, šķidruma (transudāta) uzkrāšanās audos vai ķermeṇa iekšējos dobumos. Izskaņa -itis norāda uz iekaisuma procesu (Rudzītis, 2005).

Latviešu valodā pleiras patologijas jomā šobrīd nav stingru norāžu, kādi termini kādos gadījumos jālieto. Praksē ḷoti bieži tiek lietots jēedziens "pleiras izsvīdums". Akadēmiskajā terminu datubāzē termins "izsvīdums" netiek saistīts ar terminu "pleira”, savukārt latviešu valodas skaidrojošajā brīvpieejas vārdnīcā "Tēzaurs" šim vārdam ir vairākas nozīmes: pirmā - kā rezultāts darbības vārdam "izsvīst" - izdalīt no organisma sviedrus vai izdalīties šḳidruma veidā (par augiem). Otrā - pārklājuma atsevišķu sastāvdaḷu (krāsvielu, pildvielu, plastifikatoru) migrācija uz pārklājuma virsmas, mainot tā vizuālo kvalitāti un ekspluatācijas īpašības. Jādomā, ka termins "pleiras izsvīdums" ir krievu valodas termina плевральныцй bbınom kalks latviešu valodā. Šobrīd šis termins tiek lietots tādā pašā nozīmē kā anglu termins pleural effusion, kas nozīmē jebkuras etiologijas šķidrumu pleiras dobumā. N̦emot vērā iepriekš aprakstīto, šajā darbā nolemts vārdu "izsvīdums" nelietot, aizstājot to ar vārdu "šķidrums".

Attīstoties izpratnei par pleiras šḳidruma veidošanās diviem dažādiem ḷoti būtiski atšķirīgiem mehānismiem, kuru rezultātā rodas vai nu transudāts, vai arī eksudāts, arī terminologijijā būtu nepieciešams atspoguḷot šīs divas būtiski atšķirīgās slimības.

Latviešu valodā bieži nepamatoti tiek lietots termins "hidrotorakss", arpzīmējot jebkuras etiolog̣ijas šḳidrumu pleiras dobumā. Rudzī̌sa vārdnīcā hydrotorax ir sinonīms terminam hydrops pleurae, kas nozīmē transudāta uzkrāšanos pleiras dobumā. Jātzīmē arī, ka temins "serozs" netiek lietots kā sinonīms vārdam "transudatīvs". Tāpēc šo terminu vajadzētu lietot tikai tad, kad runa ir par transudāta uzkrāšanos pleiras dobumā (piemēram, kardiāls hidrotorakss, hepātisks hidrotorakss). Tāpat arī dažkārt nepamatoti tiek lietots termins “eksudāts", ar to apzīmējot jebkuras izcelsmes šķidrumu. Termins "eksudāts" būtu jālieto gadījumos, kad šḳidrums pleiras dobumā patiešām ir eksudāts pēc izcelsmes mehānisma un bioḳīmiskajām īpašībām. Terminu "pleirīts" ir grūti attiecināt uz visiem eksudātu gadījumiem (piemēram, karcinomatozs pleirīts), tā kā iekaisīga procesa patoǵenēza atšķiras no ḷaundabīga procesa patoǵenēzes. Tāpēc šajā darbā tiek izmantots termins "maligns pleiras eksudāts", apzināti lietojot vārdu "maligns" (latīniski malus - l̦auns, slikts), kas ir termins, kuru tradicionāli pieņemts lietot galvenokārt saistībā ar ḷaundabīgiem audzējiem pretstatā latviešu vārdam "ḷaundabīgs", kuru var lietot arī tad, ja slimībai nav saistības ar ḷaundabīgu šūnu 
proliferāciju, piemēram "ḷaundabīga hipertensija". Ja eksudāts pleiras dobumā radies pneimonijas dēl, tad to sauc par parapneimonisku pleirītu, kura sinonīms ir parapneimonisks eksudāts. 


\section{PLEIRAS DOBUMA ANATOMIJA UN FIZIOLOG̣IJA}

Pleiras dobums ir sprauga starp pleiras lapiṇām un fiziologisiskos apstākḷos ir vidēji 10$20 \mu \mathrm{m}$ plats. To izklāj viscerālā pleira, kas pārklāj plaušu un parietālā pleira, kas pārklāj krūšu kurvja sienu no iekšpuses un diafragmu. Abas pleiras lapiņas savienojās pie plaušu saknes, bet pleiras dobumā viscerālā un parietālā pleira normālos apstākḷıs saskaras minimāli, tāpēc pleiras dobums ir reāls nevis potenciāls dobums (Albertine et al., 1991). Pleiras dobumā ir neliels daudzums šķidruma - vidēji 0,1-0,2 ml/kg ķermeņa svara (Lai-Fook et al., 2004). Šis šķidrums pārklāj visu pleiras virsmu apmēram $1000 \mathrm{~cm}^{2}$ laukumā.

Histoloǵiski pleiru veido 5 slāṇi:

1) vienkārtains mezotēlija šūnu slānis;

2) plāns virspusējais saistaudu slānis, kas ietver arī bazālo plātnīti;

3) virspusējais elastīgais slānis;

4) irdens saistaudu slānis;

5) dziḷais, fibroelastīgais slānis.

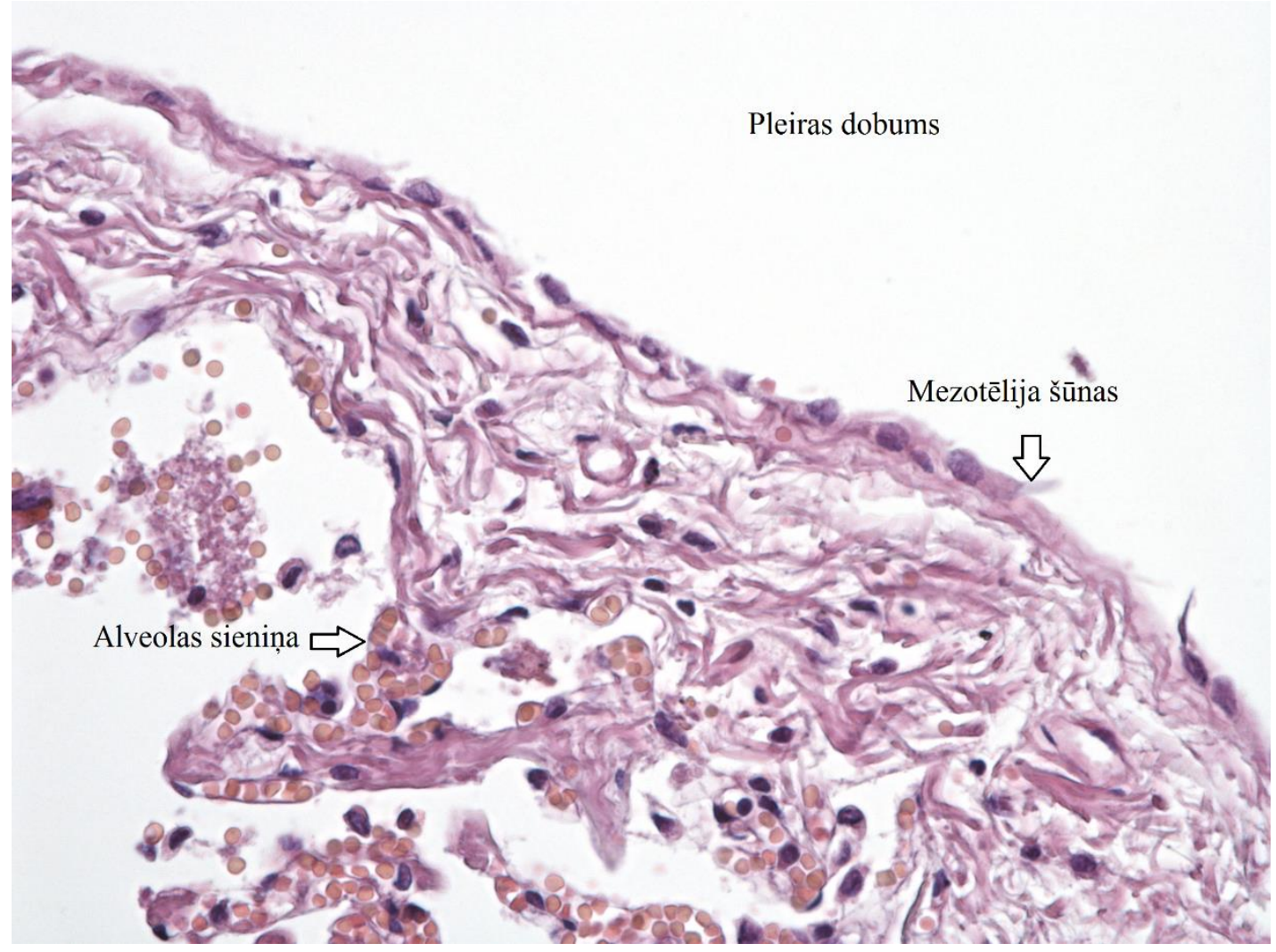

2.1. attēls. Viscerālās pleiras histoloğiskā uzbūve (Foto no Māra Spergas (RAKUS) arhīva)

Robeža starp virspusējo saistaudu slāni un elastīgo šķiedru slāni nav noteikta. Irdenajā saistaudu slānī atrodas taukaudi, fibroblasti, tuklās šūnas un citas mononukleāras šūnas, 
asinsvadi, nervi un limfvadi. Dziḷais fibroelastīgais slānis cieši saistīts un bieži vien saplūst ar plaušu parenhīmu, videni, diafragmu, krūšu kurvja muskuḷiem un ribām (Light et al., 2003).

Pleiru veido viens mezotēlija šūnu slānis. Mezotēlija šūnām ir 3-5 $\mu \mathrm{m}$ mikroskropstinas (Broaddus et al., 2016). Dažādām zīin̄tāju sugām viscerālās pleiras biezums ir dažāds. Cilvēkam, tāpat kā aitām, zirgiem, cūkām un govīm ir "bieza" viscerālā pleira $(25-100 \mu \mathrm{m})$ (Albertine et al., 1982, McLaughlin et al., 1961), bet, piemēram, suṇiem, trušiem, pelēm un žurkām ir "plāna" viscerālā pleira - no 5 līdz $20 \mu \mathrm{m}$ (Oldmixon et al., 1982). Pleiras biezums atkarīgs no saistaudu slāṇa biezuma zem mezotēlija šūnām. Sugām ar "biezu" viscerālo pleiru tās asinsapgādi nodrošina lielais asinsrites loks caur bronhiālām artērijām, bet sugām ar "plānu" viscerālo pleiru asinsapgādi nodrošina mazais asinsrites loks caur plaušu artērijām. Šādu atšķirību iemesls pagaidām nav zināms (Broaddus et al., 2016). Parietālai pleirai zem mezotēlija ar skropstiṇām klātā šūnu slāṇa visām zīdītāju sugām ir plāns saistaudu slānis, kas satur lielā asinsrites loka asinsvadus, nervus un limfvadus (Albertine et al., 1984). Parietālās pleirā starp mezotēlija šūnām galvenokārt kaudālā rajonā daudzām zīdītāju sugām, t.sk., cilvēkam ir konstatētas atveres ar diametru 2-10 $\mu \mathrm{m}$ - stomas, kuras nodrošina limfvadu un pleiras dobuma savienojumu, caur kuru virzienā uz limfvadiem virzās šūnas un makromolekulas (Agostoni et al., 2007).

Parietālās pleiras asinsapgāde notiek caur lielā loka artērijām un venozās asinis plūst uz lielā loka vēnām. Viscerālo pleiru arī apgādā lielā asinsrites loka artērijas, kas atdalās no bronhiālām artērijām, bet, atškịirībā no parietālās pleiras, venozās asinis aizplūst uz mazā loka venozo sistēmu. Limfa nonāk dažādos reǵionālos limfmezglos, tomēr kopumā uz labo limfătisko vadu vai $d$. thoracicus (Weinberger et al., 2013).

Parietālā pleira satur daudz sensoro nervgalu, kas ir interkostālo vai diafragmālo nervu zaru nobeigumi, tāpēc parietālā pleirā var veidoties spēcīgi sāpju impulsi. Sāpju lokalizācija interkostālo nervu kairinājuma gadījumā ir krūšu kurvja siena, bet diafragmālā nerva kairinājuma gadījumā sāpes var irradiēt arī uz plecu (Broaddus et al., 2016). Arī viscerālā pleirā ir atklāti sensorie nervgali, kas arī var radīt sāpju vai elpas trūkuma sajūtas (Pintelon, 2007). Pleiras saaugumi var saturēt nervu šķiedras, kas izskaidro sāpes pēc torakotomijas un talka pleirodēzes (Montes et al., 2006).

Pēdējos 20 gados tiek uzskatîts, ka normā pleiras dobuma şḳidrums drenējas no lielā asinsrites loka asinsvadiem abās pleiras lapiņās un aizplūst no pleiras caur parietālās pleiras limfātisko sistēmu (Broaddus et al., 2016). Fiziologiski pleiras dobuma šķidrums ir plazmas ultrafiltrāts. Tā filtrāciju ietekmē dažādi spēki - hidrostatiskais un osmotiskais spiediens 
kapilāros un perikapilārā telpā. Šo spēku iedarbību pieņemts aprakstīt ar Stārlinga likumu, kas raksturo šḳidruma kustību starp vaskulāro un ekstravaskulāro telpu visās ķermeņa daḷās:

$$
\text { Šķidruma kustība }=\mathrm{K}[(\mathrm{Pc}-\mathrm{Pis})-\sigma(\mathrm{COPc}-\mathrm{COPis})] \text {, }
$$

kur $\mathrm{K}=$ filtrācijas koeficients (pleiras virsmas permiabilitātes rādītājs), $\mathrm{P}=$ hidrostatiskais spiediens, COP - kolō̄dosmotiskais spiediens, $\sigma$ - kapilāru olbaltumvielu caurlaidības lielums, c = kapilārā telpa, is = intersticiālā telpa.

Šin̄̄ gadījumā intersticiālā telpa ir pleiras dobums un koloīdosmotiskais spiediens pleiras šķidruma spiediens. Hidrostatiskais spiediens pleiras dobumā ir negatīvs, t. i., - $5 \mathrm{mmH}_{2} \mathrm{O}$, plaušām aizņemot funkcionālās reziduālās kapacitātes tilpumu un - $30 \mathrm{mmH}_{2} \mathrm{O}$ - totālas plaušu kapacitātes tilpumu. Galvenais faktors, kas ietekmē šķidruma filtrāciju no kapilāriem uz pleiras dobumu, ir spiedienu starpība starp pozitīvo hidrostatisko spiedienu asinsvados un negatīvo hidrostatisko spiedienu pleiras dobumā (Broaddus et al., 2016; Weinberger et al., 2013).

Pleiras škidruma un tā sastāvā esošo šūnu un proteīnu resorbcija notiek caur parietālās pleiras stomām limfātiskajos vados. Tiek uzskatīts, ka šķidruma kustību caur limfvadu vārstuḷiem nodrošina elpošanas kustības (Broaddus et al., 2016). 


\section{PATOLOG̣ISKS ŠĶIDRUMS PLEIRAS DOBUMĀ}

Fiziologiski pleiras šķidruma filtrācija uz pleiras dobumu un resorbcija no pleiras dobuma ir līdzsvarā, tāpēc palielināts šķidruma daudzums neveidojas. Tomēr daudzu slimību gadījumos ir traucēta vai nu šķidruma filtrācija vai resorbcija , bet visbiežāk abi divi procesi, kā rezultātā pleiras dobumā uzkrājas lieks šḳidrums. Pleiras dobumā dažādu patoloǵiju rezultātā var nonākt arī cits šķidrums, piemēram, limfa, cerebrospinālais šķidrums, urīns, asinis. Pierādīts, ka resorbcijas traucējumi rodas limfvadu un stomu obstrukcijas rezultātā, galvenokārt tuberkulozes un malignu pleiras slimību gadījumos (Broaddus et al., 2016).

Izmaiņas jebkurā no Stārlinga likuma lielumiem var izraisīt šḳidruma apmaiṇas traucējumus. Praksē šos traucējumus iedala divās grupās: pirmā - izmaiņas pleiras caurlaid̄̄bā, t.i., izmainās filtrācijas koeficients K un kapilāru olbaltumvielu caurlaidības koeficients $\sigma$. Šinī gadījumā caur pleiru izfiltrējas lielāks šḳidruma daudzums un lielākas molekulmasas asins sastāvdaḷas, tostarp olbaltumvielas. Otrā - izmaiṇas hidrostatiskā un osmotiskā spiediena izmaiṇas parietālās un viscerālās pleiras kapilāros bez pleiras caurlaidības izmaiṇām. Pirmajā gadījumā patologiskais pleiras šķidrums satur daudz olbaltumvielu un to sauc par eksudātu. Otrajā gadījumā patologiiskais šķidrums pleiras dobumā joprojām ir plazmas ultrafiltrāts un to pieņemts saukt par transudātu (Broaddus et al., 2016).

Transudāti ir dažādi zemas olbaltumvielu koncentrācijas šķidrumi, lielākajā to daḷā cēlonis ir sirds mazspēja. Šajos gadījumos šķidrums vispirms nokḷūst plaušu interstīcijā un tālāk paaugstināta hidrostatiskā spiediena rezultātā pleiras dobumā (Wiener-Kronish et al., 1993). Transudāts nefrotiskā sindroma gadījumā pleiras dobumā nokḷūst samazināta osmotiskā spiediena rezultātā, bet transudāts aknu cirozes gadījumā vai peritoneālās dialīzes šķīidums no vēdera dobuma pleiras dobumā caur makroskopiskām diafragmas atverēm nokḷūst subatmosfēriskā pleiras dobuma spiediena dēḷ.

Transudāti novērojami šādu patologiiju gadījumos (Broaddus et al., 2016):

- sirds mazspēja;

- aknu mazspēja ar portālu hipertensiju un ascītu;

- nefrotisks sondroms;

- peritoneālā dialīze;

- urinotorakss;

- miksedēma;

- V.cava kompresijas sindroms;

- subarahnoidālapleirāla fistula. 
Eksudāti rodas pleiras, plaušas vai citu blakus esošo audu kapilāru sienas caurlaidības paaugstināšanās rezultātā. Eksudāti, kas saistīti ar iekaisumu plaušas audos (pneimonija, plaušu artērijas trombembolija - PATE), iespējams, rodas no augstas olbaltumvielu koncentrācijas šķidruma tūskas plaušu audos. Eksudāti var rasties arī pleiras lapiṇu bojājuma dēl (iekaisums, infekcija, malignitāte). Eksudāts pleiras dobumā var nokḷūt arī no videnes (barības vada ruptūra vai hilotorakss), retroperitoneālās telpas (aizkuṇǵa dziedzera pseidocista) vai no vēdera dobuma (ascīts ar spontānu bakteriālu peritonītu vai Meigsa sindroms). Tā kā šķidruma absorbcijas ātrums limfātiskajā sistēmā neizmaina olbaltumvielu koncentrāciju, tad tā dod informāciju tikai par šḳidruma veidošanās nevis absorbcijas mehānismiem un limfvadu stāvokli (Broaddus et al., 2016).

Eksudāti novērojami šādu slimību gadījumos (Broaddus et al., 2016):

- L,aundabīgas slimības:

○ Mezotelioma;

○ Metastātiski audzēji;

○ Limfomas;

- Infekcijas slimības:

○ Bakteriālas infekcijas (visbiežāk pneimonija);

○ Aktinomikoze un nokardioze;

○ Sēṇu infekcijas;

○ Vīrusu infekcijas;

○ Tuberkuloze;

○ Parazītu invāzijas;

- Gastrointestinālas slimības:

○ Barības vada perforācija;

○ Intraabdomināls abscess;

○ Iekaisuma procesi vēdera dobuma orgānos;

- Saistaudu slimības:

○ Reimatoīdais artrīts;

○ Sistēmsikā sarkanā vilkēde;

- Šegrēna sindroms;

○ Imunoblastiskā limfadenopātija;

- Granulomatoze ar poliangītu (Vegenera sindroms);

○ Eozinofilā granulomatoze ar poliangītu (Čērdža-Strosas sindroms);

- Pleirīts pēc sirds operācijām; 
- Azbestoze;

- Sarkoidoze;

- Urēmija;

- Meigsa sindroms;

- Olnīcu hiperstimulācijas sindroms;

- Dzelteno nagu sindroms;

- Medikamentu izraisīti pleirīti:

○ Nitrofurantoīns;

○ Dantrolēns;

○ Bromkriptīns;

○ Amiodarons;

- Staru terapija;

- Hemotorakss;

- Hilotorakss.

Primāra pleiras patologija ir tikai divas no minētajām slimībām - tuberkulozs pleirīts un mezotelioma, pārējos gadījumos šķidrums pleiras dobumā rodas kā komplikācija kāda cita orgāna patolog̣ijai.

Visbiežāk sastopamās etiologijas šķidrumi pleiras dobumā ir kardiāls hidrotorakss, parapneimonisks pleirìts un maligns pleiras eksudāts (MPE) (Broaddus et al., 2016).

\subsection{Pleiras patoloğijas epidemioloǵija un incidence}

N̦emot vērā faktu, ka šķidrums pleiras dobumā visbiežāk nav primāra pleiras slimība, bet gan kādas citas slimības komplikācija vai izpausme, tad epidemioloǵiskos datus par šīs patologijas incidenci savākt ir grūti. Pētījumos par šķidrumu pleiras dobumā vislielākā vērība parasti tiek pievērsta diagnostikas un ārstēšanas taktikai. Eksistē pavisam nedaudzi maza slimnieku skaita pētījumi, kuru mērḳis ir noskaidrot pleiras patologijas incidenci.

Līdz šim vislabākā dizaina pētījumu publicējis Marel ar kolẹgiem. Viṇi 1993. gada laikā stingri definētā Bohēmijas reg̣ionā, kurā ir 44000 iedz̄ivotāju, identificēja visus pacientus ar šķidrumu pleiras dobumā un konstatēja, ka gada laikā šādu pacientu bija 142 (93 - dzīviem pacientiem, 49 - autopsijās), t. i., pleiras šḳidruma incidence šajā reǵionā bija 0,32\%. Visbiežāk šķidrums pleiras dobumā bija sirds mazspējas dēl, (46\%), 22 \% konstatēja MPE, $17 \%$ - parapneimonisku eksudātu, 5,6\% - PATE. Citas etiologijas šḳidrumu pleiras dobumā bija mazāk - intraabdominālus procesus konstatēja 4 pacientiem, urēmiju - 2, miksedēmu - 1, 
reimatoīdo pleirītu - 1 un citas etiologijas šķidrumu pleiras dobumā, tostarp hemotoraksu, 6 pacientiem (Marel et al., 1993).

Arī pētījumi par dažādu etioloǵisko faktoru izraisīta pleiras dobuma şķidruma incidenci nav viegli veicami. Jādomā, ka etioloǵiskie faktori dažādos reǵionos atšḳirās. Tā, piemēram, reǵionos ar augstu tuberkulozes izplatību samērā lielu dạ̧u no visiem šķidrumiem pleiras dobumā aizṇem tuberkulozie pleirīti. Valdes un kolēgi 1996. gadā publicētajā rakstā ziṇoja par 5 gadus ilgu prospektīvu daudzcentru pētījumu, kurā iekḷauti 642 pacienti ar šķidrumu pleiras dobumā. Starp šiem pacentiem visbiežākais pleiras dobuma eksudāta iemesls bija tuberkuloze (25\%), MPE konstatēja 22,9 \% pacientu, hronisku sirds mazspēju - 17,9 \% pacientu. Sīkāk analizējot MPE grupu, konstatēja, ka visbiežākais cēlonis ir plaušu vēzis $(32,6$ \%), krūts vēzi konstatēja 11,5\%, limfomu - 10,8 \% un nezināmas lokalizācijas audzēji - 14,3\% gadījumu no visiem MPE (Valdes et al., 1996). Liam ar kolēgiem retrospektīvi pētīja eksudātu etioloǵiskos faktorus 4 gadu ilgā laika posmā reǵionā ar izplatītu tuberkulozi un konstatēja, ka starp 186 pacientiem 44,1\% diagnosticēja tuberkulozu pleirītu, bet $29 \%$ pacientu - MPE. Arī Ziemeḷlibānā pētījumā ar 165 pacientiem ar dažādas etiologiijas pleiras eksudātu konstatēts, ka 43,7\% pacientiem eksudātā cēlonis bija tuberkuloze, bet 32,1 - MPE (Kalaajieh, 2001). Savukārt Kauņā veiktā pētījumā analizēta 200 pacienti ar šķidrumu pleiras dobumā, no kuriem tuberkuloze bija tikai 6\% paientu, MPE - $16 \%$, parpapneimonisks eksudāts - $13 \%$, PATE $5,5 \%$ pacientu, bet $24 \%$ pacientu šķidrums bija transudāts.

Kaut gan nav pieejami epidemiologiski pētījumi par malignu pleiras eksudātu incidenci, tomēr ir aplēsts, ka ASV katru gadu saslimst 150 000-200 000 cilvēku (Antony et al., 2001), bet Lielbritānijā ir 50000 jaunu gadījumu gadā (Rahman et al., 2010). Apmēram 30 \% pacientu tā ir pirmā malignitātes manifestācija. Maligni pleiras eksudāti sastāda lielāko daḷu no visiem pleiras dobuma eksudātiem - 42 \%-77 \% (Marel et al., 1993., Valdes et al., 1996).

Vairāki pētījumi veikti par primārā pleiras audzēja mezoteliomas incidenci, kura ir atkarīga no azbesta ekspozīcijas intensitātes un ilguma uz iedzīvotājiem un tāpēc dažādās valstīs ir ḷoti dažāda. Tā, piemēram, Islandē 2014. gadā mezoteliomas incidence bija 21,4 / 1000000 vīriešu un 5,6 / 1000000 sieviešu gadā (Tomasson et al., 2016). Savukārt Montanaro un kolēǵu 2003. gadā publicētie dati par mezoteliomas incidenci Eiropā, kas iegūti, apkopojot datus no lokāliem vēža reǵistriem un datus par azbesta ekspozīcijas izmain̄ām 1986. līdz 1995. gados, parāda, ka saslimstība ar mezoteliomu variē no 8 gadījumiem uz 100000 iedzīvotāju gadā Skotijā, Anglijā un Nīderlandē līdz mazāk nekā 1 gadījumu uz 100000 Spānijā - incidence 0,96. Igaunijā mezoteliomas incidence bij 0,85, Polijā - 0,85, Dienvidslāvijāa -0,56. 


\subsection{Transudāts}

Transudāts pleiras dobumā var izveidoties dažādu slimību gadījumos - sirds mazspējas, nieru mazspējas un aknu mazspējas pacientiem. Kaut arī neeksistē plaši pārliecinoši pētījumi par transudāta incidenci dažādu patoloǵiju gadījumos, tomēr ir skaidrs, ka kardiāls hidrotorakss ir visbiežāk sastopamais transudātu veids. Lai gan piejamu pētījumu šajā jomā ir maz, tomēr ir skaidrs, ka hroniskas dekompensētas sirds mazspējas pacientiem hidrotoraksa incidence ir augsta. Pētījumā ar 60 dekompensētas sirds mazspējas pacientiem ultrasonoskopiski konstatēja, ka 50 pacientiem (83 \%) ir labās puses hidrotorakss, 46 pacientiem (77 \%) ir kreisās puses hidrotorakss (Kataoka et al., 2000).

Kardiāls hidrotorakss bieži ir abpusējs, bet, ja tas ir vienpusējas, tad lielākoties to konstatē labās puses pleiras dobumā, iespējams, tādēḷ, ka labā plauša ir lielāka apjomā, līdz ar to šeit ir lielāks kopējais asinsvadu tilpums. Biežāk kardiālu hidrotoraksu novēro pacientiem, kuriem ir arī rentgenoloǵiskas vai datortomogrāfiskas plaušu tūskas pazīmes (Broaddus et al., 2016).

Kardiāla hidrotoraksa patoǵenēzes pamatā ir paaugstināts spiediens kapilāru gultnē, kādēl notiek šķidruma filtrācija caur asinsvadu sieniņām un mezotēliju. Kardiāls hidrotorakss ir transudāts ar zemu olbaltumvielu un šūnu saturu (Broaddus et al., 2016).

\section{3. Eksudāts}

\subsubsection{Pleiras dobuma infekcija, parapneimonisks pleirīts un pleiras empiēma}

Iekaisīga rakstura šķidruma gadījumā asinsvadu sieniņas un mezotēlija membrānas caurlaidību palielina baktēriju, liposaharīdu, citokīnu un hemokīnu iedarbība. Baktēriju sieniņu ražotās vielas piesaistās pie mezotēlija šūnām un stimulē interleikīna 1, interleikīna 8, epitēlija neitrofîlo aktivācijas proteīna, tumora nekrozes faktora $\alpha$ un trombocītu aktivētājfaktora produkciju, kā rezultātā asinsvadu sieniņas caurlaidība palielinās un uz pleiras dobumu migrē neitrofîlie leikocīti un makrofāgi. Parapneimoniskā pleirìtā ir paaugstināta prokoagulantu un samazināta fibrnolītiskā aktivitāte, kas stimulē fibrīna izgulsnēšanos pleiras dobumā un paaugstinātu fibroblastu aktivitāti (Septimus et al., 2015).

Parapneimoniska pleirīta attīstību mēdz iedalīt trīs stadijās. Pirmajā - eksudatīvajā stadijā raksturīga ātra sterila eksudāta uzkrāšanās pleiras dobumā paaugstinātas asinsvadu caurlaidības dēḷ. Otrajā - fibrobpurulentā - stadijā eksudātā nokḷūst baktērijas un sākas arī pastiprināta citokīnu izdalīšanās un šūnu migrācija pleiras dobumā, uz viscerālās un parietālās pleiras lapiṇām izgulsnējas fibrīns un sāk veidoties norobežoti, ar eksudātu pildīti dobumi. 
Trešo stadiju sauc par organizācijas stadiju, tai raksturīga agresīva fibroblastu augšana, kā rezultātā uz pleiras lapiņām izveidojas neelastīga membrāna jeb aplikums. Eksudāts parasti ir biezs, duļ̧̣⿻inans vai arī ir izveidojušās noformētas strutas. Šin̄̄ gadījumā parapneimonisku pleirītu pieņemts saukt par pleiras empiēmu. Retāk iespējama arī baktēriju migrācija tieši no ārpusplaušu infekcijas perēkḷa ar asinsplūsmu - šin̄̄ gadījumā ḷoti ātri veidojas fibropurulentā stadija (Maskell et al., 2016).

Drošu epidemioloǵisku datu arī par parapneimonisku pleirītu incidenci pasaulē pēdējos gados nav. Ir zināms, ka ASV gadā ar pneimoniju saslimst apmēram 1000000 cilvēku, 60000 no tiem attīstās empiēma. ASV un Kanādā kopš 1996. gada empiēmu skaits ir pieaudzis pēdējo desmitgažu laikā, turklāt pieaug arī mirstība no empiēmas. Izskaidrojuma saslimstības un mirstības pieaugumam pagaidām nav (Maskell et al., 2016).

Ir zināms, ka ar parapneimonisku pleirītu un pleiras empiēmu divreiz biežāk slimo vīrieši nekā sievietes un riska faktors šīs komplikācijas attīstībai ir diabēts, alkoholisms, dentāla infekcija un aspirācija. Parapneimoniska pleirīta un pleiras empiēmas cēlonis var būt gan sadzīvē iegūtas pneimonijas, gan arī hospitālas pneimonijas. Tāpat infekcija pleiras dobumā var nokḷūt no vēdera dobuma, barības vada plīsuma, krūšu kurvja traumas rezultātā, kā arī jatrogēnā ceḷā (Maskell et al., 2016).

Vēsturiski pleiras empiēmas izaisītājs bija Streptococcus pneumoniae - $1 \overline{1} \mathrm{dz} 60 \%$ gadījumu. Šobrīd vērojama būtiska atšķirība starp sadzīvē iegūtu un intrahospitālu pleiras empiēmas izraisītājiem. Pētījumā ar 454 pleiras empiēmas pacientiem 60 \% gadījumu bija iespējams noteikt mikrobiologisku diagnozi un tika konstatēts, ka sadzīiē iegūtu empiēmu 30 \% gadījumu izraisa Streptococcus anginosus, $13 \%$ - Streptococcus pneumoniae, bet pārējo grupu streptokoki tikai $7 \%$ gadījumu. Anareobi mikroorganismi sadzīvē iegūtu empiēmu izraisa $16 \%$, bet stafilokoki - $11 \%$ gadījumu, savukārt intrahospitālo empiēmu stafilokoki izraisa 46 \% gadījumu. Pārējos gadījumos intrahospitāli pneimoniju izraisa Gr- mikroorganismi (Maskell et al., 2005). Taivānā veiktā pētîjumā ar 602 pleiras empiēmas pacientiem, no kuriem mikrobioloǵiskā diagnoze tika noteikta $43 \%$ gadījumu, konstatēts, ka $21 \%$ parapneimoniskas pleiras empiēmas gadījumu izraisītājs bija Klebsiella pneumoniae (Chen et al., 2014).

Iespējamo izraisošo patogēnu bieži var prognozēt pēc dažādiem predispozīcijas faktoriem. Visbiežākā patolog̣ija, kas komplicējas ar pleiras empiēmu, ir pneimonija. Piemēram, sekundāru bakteriālu infekciju pēc pārslimotas gripas sevišķi vecākiem cilvēkiem ar citām slimībām, izraisa Streptococcus pneumoniae, Staphylococcus aureus un Streptococcus pyogenes, savukārt ārpus gripas epidēmijas laika un citādi veseliem pieaugušajiem stafilokoki ir maz ticami pneimonijas un pleiras empiēmas izraisītāji. Cilvēkiem ar apziṇas traucējumiem, 
alkoholismu un zobu infekcijām bieži pleiras empiēmu izraisa anaeroba un polimikrobiāla infekcija. Legionellu un mikoplazmu izraisīti parapneimoniski pleirīti parasti ir nelieli un tiem ir tieksme spontāni resorbēties. Pacientiem pēc ķirurğiskām manipulācijām vai traumām pleiras šķidrumā bieži atrodami Staphylococcus aureus un Gr- mikroorganismi. Imūnkompromitētiem pacientiem pleiras empiēmu var izraisīt arī sēnes (Septimus, 2015). .

\subsubsection{Tuberkulozs pleirīts}

Tuberkulozs pleirīts tiek uzskatīts par ārpusplaušu tuberkulozes formu un tā sastopama biežāk vīriešiem kā sievietēm vecumā no 5 līdz 45 gadiem. HIV inficētiem pacientiem tuberkulozi pleirīti sastopami biežāk. Tuberkuloza pleirīta etiologija var būt divejāda tuberkulozes mikobaktērijas agrīnā inficēšanās fāzē var nokḷūt pleiras dobumā un izraisīt hipersensitivitātes reakciju. Šādos gadījumos pleirīts izzūd spontāni un bieži paliek nediagnosticēts, tomēr šiem cilvēkiem ir lielāks risks saslimt ar tuberkulozi nākošo 2 gadu laikā. Citiem pacientiem tuberkulozes mikobaktērijas izraisa akūtu slimību ar sāpēm krūšu kurvī, drudzi un elpas trūkumu (Hopwell et al., 2016). Pleiras šķidrumā izteikti dominē monomorfas nukleārās $(\mathrm{MMN})$ šūnas un eozinofilo leikocītu klātbūtne padara tuberkuloza pleirīta diagnozi maz ticamu. Pleiras šķidruma mikroskopijā acidorezistentās baktērijas atrod ḷoti reti, bet tā uzsējums ir pozitīvs 20-40 \% gadījumu. Visaugstākā diagnostiskā vērtība ir pleiras biopsijai torakoskopiska pleiras biopsija reti ir bez diagnostiskas vērtības, tomēr ne visur tā ir pieejama, bet slēgtā pleiras biopsijā diagnozi histoloǵiski un mikrobioloǵiski precizē 65-75\% gadījumu, atkārtotas slēgtas pleiraa biopsijas diagnostiskā vērtība ir 80-90 \% (Hopewell et al., 2016).

\subsubsection{Maligns pleiras eksudāts (MPE)}

Primārs pleiras audzējs ir vienīgi mezotelioma, pārējie MPE ir citas lokalizācijas audzēja diseminācijas rezultāts. Visbiežāk ar MPE komplicējas plaušu audzēji - 37,5 \%, krūts dziedzera audzēji - 16,8 \%, limfomas - 11,5\%, gastrointestinālā trakta audzēji $-6,9 \%$, uroǵenitālā trakta audzēji - 9,4 \% un citas zināmas lokalizācijas audzēji - 7,8\% no visiem MPE. 10,7 \% MPE primāro lokalizācija nav zināma (Roberts et al., 2010).

Maligni pleiras eksudāti dažkārt tiek iedalīti malignos un paramalignos eksudātos. Par paramaligniem var tikt uzskatīti pleiras eksudāti, kas rodas nevis pleiras metastāžu dēḷ, bet audzēja lokālas (postobstruktīva pneimonija, atelektāze, limfvadu obstrukcija) un sistēmiskas (PATE, hipoalbuminēmija) iedarbības rezultātā (Sahn, 1997 Antunes et al., 2003). Tomēr pēdējā laikā šāds iedalījums vairs netiek aktualizēts. 
Audzēja šūnas var nokḷūt pleirā gan caur asinsriti, gan limfătiskā ceḷā gan arī tieši ieaugot no blakus esošām struktūrām (piemēram, plaušas, krūšu kurvja sienas, diafragmas). Audzēja invāzijas patoǵenēze pleirā līdz šim ir maz pētîta. Malignā pleiras eksudātā ir daudz citokīnu, kas inhibē imunologiskās atbildes reakcijas, tajā ir daudz imunosupresīvo CD4 ${ }^{+}$ limfocītu, bet CD8+ limfocītu, kuriem ir citotoksisks potenciāls, ir maz. Makrofāgi, kuri atrodas malignā pleiras eksudātā, ne tikai uzrāda samazinātu citotoksisko aktivitāti, bet arī inhibē audzēja šūnu apoptozi (Psallidas et al., 2016).

Tiek uzskatīts, ka pleiras dobuma šķidruma drenāža notiek caur parietālās pleiras stomām un limfvadiem. Ja šīs struktūras infiltrē audzēja audi, tad šķidruma drenāža no pleiras dobuma ir apgrūtināta un tas ir viens no galvenajiem malignu pleiras eksudātu formēšanās mehānismiem. Tomēr, pēc dažu autoru domām (Psallidas et al., 2016; Stathopoulos et al., 2012; Sakr et al., 2011), parasti maligna pleiras eksudāta daudzums ir daudz lielāks nekā varētu sagaidīt, ja tā cēlonis būtu tikai resorbcijas traucējumi. Turklāt, lielākajā daḷā malignu pleiras eksudātu olbaltumvielu līmenis ir augstāks nekā transudātos, kas liecina par pleiras filtrācijas spēju izmain̄ām, tāpat malignu pleiras eksudātu novēro pacientiem, kuriem patologiskajā procesā parietālā pleira nav iesaistīta, turklāt tikai 55-60 \% pacientu ar pleiras metastāzēm ir arī eksudāts pleiras dobumā (Light et al, 1997). Tāpēc domā, ka malignu pleiras eksudātu gadījumos patoǵenētiskais mehānisms ir arī šķidruma ekstravazācija caur palielinātas caurlaidības viscerālās vai parietālās pleiras un/vai audzēja asinsvadiem (Psallidas et al., 2016).

Nav līdz galam skaidrs mehānisms, kāpēc pacientiem ar malignu pleiras eksudātu palielinās asinsvadu sieniņas caurlaidība. Sākotnēji uzskatīja, ka asinsvadu sieniṇu caurlaidības paaugstināšanās cēlonis ir vazoaktīvās vielas (vaskulārais endotēlija augšanas faktors), kuras izdala audzējs. Pēdējā laikā arvien biežāk tiek rakstīts par to, ka pastiprinātu šķidruma izdalīšanos pleiras dobumā nosaka ne tikai audzēja, bet arī saimnieka šūnas, respektīvi, iekaisuma, mezotēlija, mieolīdās, limfoīdās un endotēlija šūnas ar vazoaktīviem mediatoriem (vaskulārais endotēlija augšanas faktors, tumora nekrozes faktors, hemokīna ligands 2, osteopontīns u.c.) mijiedarbojas ar audzēja šūnām. Šīs mijiedarbības rezultātā aktivējas onkogēno signālu transkripcija audzēja šūnās, kas, savukārt, rada pastiprinātu saimnieka šūnu migrāciju uz pleiras dobumu. Tādejādi gan saimnieka, gan audzēja šūnu izdalītie vazoaktīvie mediatori prevalē pār iespējamām protektīvajām molekulām (piemēram, endostatīnu) un rada asinsvadu sieniņas palielinātu caurlaidību, iekaisumu un angioneoǵenēzi, kā rezultātā veidojas MPE (Psallidas et al., 2016, Stathopoulos et al., 2012). 50-65 \% gadījumu MPE ir plaušu vai krūts adenokarcinomas komplikācija. Pacientiem, kuriem ir plaušu vēzis, MPE attīstās 
apmēram $30 \%$ gadījumu, bet pacientēm ar krūts vēzi - 7-11\% gadījumu. 7-11 procentos primārā vēža lokalizācija netiek konstatēta (Penz et al., 2017).

MPE ir slimība vai slimības komplikācija ar sliktu prognozi - vidējā dzīvildze pēc diagnozes noteikšanas ir 3-18 mēneši (Psallidas et al. 2015; Sakr et al, 2011; Jimenez et al, 2005). Prognoze ir atkarīga no primārā audzēja lokalizācijas - krūts dziedzera un dzemdes kakla vēzi tā ir lielāka nekā pacientiem ar citām primārā audzēja lokalizācijām (Zamboni et al., 2015).

\subsubsection{Pleiras eksudāts plaušu artērijas trombembolijas (PATE) gadījumā}

Pleiras eksudāts PATE gadījumā, pēc dažu autoru domām, ir vissliktāk diagnosticētais eksudāta veids. Tā, piemēram, pēc Stein aprēķiniem, 30\% plaušu emboliju viens no simpotomiem ir pleiras eksudāts (Stein et al., 1998). N,emot vērā, ka ASV katru gadu ar PATE saslimst 500000 cilvēku, būtu jābūt diagnosticētiem 150000 pleiras eksudātu PATE dēl, tomēr šie eksudāti tiek aprakstīti mazāk kā MPE plaušu vēža gadījumos (Broaddus et al., 2016). Šķidrums PATE gadījumos pleiras dobumā visticamāk nokḷūst paaugstinātas kapilāru ceurlaidības dēl, ko izraisa iekaisuma mediatori (piemēram, asinsvadu endotēlija augšanas faktors), kurus savukārt izdala trombocīti (Cheng et al., 1999). PATE pleiras eksudāta gadījumos simptomi parasti ir sāpes krūtīs un asinsspḷaušana. un tas var būt gan abpusējs, gan vienpusējs. Pleiras punktāta analīzei parasti nav lielas diagnostiskas nozīmes - pleiras punktāts gandrīz vienmēr ir eksudāts un tā šūnu sastāvā var dominēt gan polimorfnukleāras, gan monomorfas nukleāras šūnas, gan eozinofilie leikocīti. Galvenā diagnostikas metode šādos gadījumos ir plaušu asrtēriju datortomogrāfiska angiogrāfija (Porcel, 2007).

\subsection{Pleiras šķidruma diagnostikas metodes}

\subsubsection{Simptomi}

Kopumā šķidrumam pleiras dobumā nav specifisku simptomu. Simptomi visbiežāk ir atkarīgi no pamatslimības un šķidruma daudzuma. Vadošais simptoms ir elpas trūkums fiziskas slodzes laikā un/vai miera stāvoklī. Tomēr konstatēts, ka elpas trūkuma izteiktība slikti korelē ar šķidruma daudzumu pleiras dobumā, tāpēc tiek uzskatīts, ka elpas trūkumu izraisa dažādi mehānismi, ne tikai mehāniska plaušas saspiešana šḳidruma ietekmē. Par to liecina arī dati, ka apmēram 15\% pacientu pēc pleiras dobuma punkcijas elpas trūkums nemazinās (Mishra et al., 2015).

Samērā bieža sūdzība ir dažāda rakstura sāpes. Iekaisīgu procesu gadījumā sāpes sākas pēkšṇi, mēdz būt durošas, dedzinošas, plēsošas. Krājoties šḳidrumam pleiras dobumā, sāpju 
intensitāte parasti mazinās. Sāpes pastiprinās, dziḷi elpojot, klepojot, šķaudot. Nereti tās ir mazāk intensīvas, guḷot uz slimā sāna. Ļaundabīga procesa gadījumā sāpes ir trulas, spiedošas vai velkošas, to raksturs var mainīties pēc pleiras punkcijas. Diafragmas sāpes izstaro uz plecu, dažkārt uz vēderu (Light et al., 2013).

Kā viens no pavadošiem simptomiem pleiras šķidruma gadījumā ir klepus, kas parasti ir sauss, biežāk saistīts ar augšējo vai dziḷāko elpceḷu iekaisumu. Asins piejaukums krēpās ir būtisks bronhokarcinomas simptoms maligna pleirīta gadījumā, bet var būt arī destrukīvas pneimonijas gadījumā vai sirds mazspējas pacientiem (Light et al., 2003).

\subsubsection{Objektīvā izmeklēšana}

Krūšu kurvja apskate pleiras šķidruma gadījumā parasti ir mazinformatīva. Masīva šķidruma daudzuma gadījumos var novērot bojātās puses ribstarpu paplašināšanos un izsp̄ilēšanos, var būt arī samazinātas elpošanas kustības bojātajā pusē.

Ja šķidruma daudzums ir pietiekami liels, lai radītu pleiras dobumā pozitīvu spiedienu, var sapalpēt palielinātu ādas pretestību ribstarpās. Uzliekot roku uz krūšu kurvja un liekot pacientam izteikt vārdus ar zemiem toṇiem ("trīs reiz trīs" vai "trīsdesmit trīs"), jūtama vibrācija - fremitus pectoralis. Ja pleiras dobumā ir šḳidrums, fremitus ir novājināts slimajā pusē.

Perkusija ir svarīgākā un informatīvākā fizikālās izmeklēšanas metode pleiras dobuma šķidruma gadījumos. Šì metode balstīta uz parastās plaušu perkutorās skaņas saīsināšanos, ja zem perkutējamās vietas nav gaisu saturošas, rezonējošas telpas, bet gan, piemēram, šķidrums pleiras dobumā vai plaušu infiltrāts. Ar perkusijas metodi var samērā precīzi noteikt šķidruma augšējo robežu.

Auskultatīvi virs šķidruma pleiras dobumā elpošana ir novājināta vai nav izklausāma vispār (Mccool, 2015).

\subsubsection{Attēldiagnostika}

Krūšu kurvja rentgenogrāfija parasti ir pirmā izmeklēšanas metode, ar kuru diagnosticē šķidrumu pleiras dobumā. Frontālā rentgenogrammā, pacientam stāvot, $75 \mathrm{ml}$ brīva šķidruma aizēno mugurējo kostodiafragmālo sinusu, $150 \mathrm{ml}$ - laterālo kostodiafragmālo sinusu, $500 \mathrm{ml}$ - diafragmu un ir redzami arī guḷus rentgenogrammās, $1000 \mathrm{ml}$ sasniedz 4. ribas līmeni priekšpusē. Mazākais brīva šķidruma daudzums, ko var redzēt rentgenogrammā, pacientam atrodoties guḷus uz sāna, ir $10 \mathrm{ml}$. Šḳidrums var izvietoties arī subpulmonāli un tādā gadījumā var konstatēt augstāku diafragmas kupolu slimajā pusē - diaframgas kupols ir novirzîts laterāli 
un veido asi konturētu virsotni, t.s. "Gibraltāra" simptomu. Šķidrums pleiras dobumā var veidot arī norobežotas kolekcijas sakarā ar fibrīna septu veidošanos. Šādas patologiskas kolekcijas parasti veido platus leņķus ar krūšu kurvja sienu un asu izliektu robežu ar plaušu (Stark, 2015). Šķidrums var sakrāties arī starpdaivu spraugās un tad to var redzēt kā abpusēji izliektu lēcu, kas var simulēt audzējus (Mccool, 2015).

Datorotmogrāfiskā (DT) izmeklēšana ir izvēles metode gadījumos, kad jādiferencē plaušu perifērus aizēnojumus no pleiras patoloǵijas. Brīvs šķidrums pleiras dobumā redzams kā sirpjveida aizēnojums zemākajā (parasti mugurējā) krūšu kurvja daḷā, bet norobežots šķidrums - kā labi norobežots lēcveida aizēnojums. Datortomogrāfiski var izmērīt šķidruma densitāti - parasti tā ir 10-20 Hounsfîlda vienības (HU). Salīdzinoši ūdenim ir 0 HU, bet mīkstajiem audiem - 100 HU. Datortomogrāfija pacientiem ar šķidrumu pleiras dobumā jāveic ar kontrastvielu, jo tādejādi var diagnosticēt arī pleiras sabiezējumus, mezglus un gūt vairāk informācijas par norobežotu šḳidrumu pleiras dobumā (Seely et al., 2008).

Ultrasonogrāfija (US) ir būtiska metode pleiras dobuma šķidruma diagnostikā. Lielākā daḷa šķidrumu pleiras dobumā ir hipoehogēni, labi norobežoti ar ehogēnu viscerālās pleiras līniju. Fibrīna septas ir labāk vizualizējamas ultrasonsoskopiski nekā datortomogrāfiski (Seely et al., 2008). Arī saaugumi pleiras dobumā (piemēram, pēc talka pleirodēzes) kuri rentgenoloǵiski var simulēt šķidrumu, ir labi atpazīstami, izmantojot US. Ultrasonoskopija ir relatīvi lēta un vienkārša metode, ko iespējams veikt gan sēdošam, gan guḷošam pacientam (Sely et al., 2008). Guḷoša pacienta krūšu kurvja rentgenogramma ir metode ar zemāku precizitāti nekā US (47 \% vs 93 \%), tā kā guḷus rentgenogrammā şķidrumu pleiras dobumā konstatēt var, ja tā daudzums ir lielāks par $200 \mathrm{ml}$, bet US var konstatēt arī $20 \mathrm{ml}$ lielu šķidruma daudzumu. Izšķir divas dažādas US tehnikas, kuras tiek izmantotas klīniskajā praksē: US izmantošana labākās punkcijas vietas konstatēšanai tieši pirms procedūras (tālāk tekstā - pirmsprocedūras US) un punkcijas veikšana US kontrolē, kad punkcijas laikā vizualizē adatu un seko tās gaitai (Prina et al., 2016). Tā kā pirmā tehnika ir salīdzinoši vienkāršāka un ātrāka, tad tā tiek izmantota biežāk. Pirmsprocedūras US, veicot jebkuru invazīvu manipulāciju pleiras dobumā, ievērojami samazina komplikāciju risku, tāpēc tā ir stingri rekomendējama. Netiek ieteikta iepriekšèja ultrasonoskopiska punkcijas vietas atzīmēšana, piemēram, attēldiagnostikas nodaḷā (Havelock et al., 2010). Ir veikti pētījumi, salīdzinot komplikāciju biežumu ar pirmsprocedūras US un bez tās. Tā piemēram, Raptopoulos et al. (1991) retrospektīvā pētījumā iekḷāva 324 pacientus, no kuriem 154 pleiras dobuma punkcija tika izdarīta vadoties pēc iepriekš veiktajiem izmeklējumiem, bet bez pirmsprocedūras US un 188 - ar pirmsprocedūras US. Pneimotorakss pēc punkcijas tika konstatēts $18 \%$ pirmās grupas pacientu un $3 \%$ otrās grupas pacientu. 
Savukārt Barnes et al. (2005) retrospektīvi izanalizēja 450 pacientu, kuriem bija veikta pleiras dobuma punkcija, medicīnisko dokumentāciju un konstatēja, ka 305 pacientiem punkcija tika izdarīta, veicot pirmsprocedūras US, bet 145 pacientiem šāda US netika veikta. Pirmās grupas pacientiem pneimotorakss tika konstatēts 4,9\% gadījumu, bet otrās grupas pacientiem - 10,3\% gadījumu. Arī punkcijas neizdošanās risks, veicot pirmsprocedūras US, ir mazāks nekā to veicot. Tomēr US izmantošana nemazina starpribu asinsvadu bojājuma risku - US šos asinsvadus nevar vizualizēt (Havelock et al., 2010).

Pozitronu emisijas tomogrāfija (PET) izmantojot fluordeoksiglikozi ir metode, ar kuras palīdzību var labi diferencēt malignus un ne-malignus pleiras šķidrumus ar jutību 88-100 \% un specifiskumu 67-94\% (Seely et al., 2008).

\subsubsection{Invazivas pleiras dobuma izmeklēšanas metodes}

\section{Pleiras dobuma punkcija}

Pleiras dobuma punkcija jeb torakocentēze ir metode, ar kuru no pleiras dobuma aspirē tajā esošo šķidrumu un/vai gaisu.

Pleiras punkcijas atkarībā no to mērķa dažkārt iedala diagostiskās (tiek aspirēts tikai neliels šķidruma daudzums laboratorai diagnostikai) un terapeitiskās - šķidrums tiek aspirēts, lai mazinātu pacienta sūdzības un evakuētu iekaisuma produktu.

Pleiras dobuma punkcijas indikācijas ir diezgan skaidras:

- neskaidras etiologijas šķidrums pleiras dobumā;

- liels šķidruma daudzums, kas rada elpošanas nepietiekamību;

- iespējams infekciozas dabas eksudāts;

- iespējams hemotorakss (Huggins et al., 2011).

Par kontrindikācijām ir dažādi viedokḷi. Huggins un kolēgii uzskata, ka absolūtas kontrindikācijas pleiras ir ārsta pieredzes trūkums, smaga koagulopātija (trombocīti < $25000 / \mu \mathrm{l} ;$ INR > 2,0), azotēmija > $530 \mu \mathrm{mol} / \mathrm{l}$, nelīdzestīgs pacients, bet relatīva kontrindikācija ir attēldiagnostikas kontroles trūkums, lai noteiktu drošu punkcijas vietu. Savukārt 2010. gada Britu Torakālās asociācijas pleiras slimību vadlīnijas par invazīvām pleiras manipulācijām un ultrasonoskopiju nosaka, ka INR līmenim pirms plāveida procedūrām jābūt $<1,5$ un trombocītu skaitam > $50000 \mu \mathrm{l}$, turklāt visiem pacientiem jāparaksta informētā piekrišana procedūrai (Havelock et al., 2010). Relatīvas kontrindikācijas ir infekciozi ādas bojājumi punkcijas vietā, hemodinamiska nestabilitāte, tāpat mākslīgā plaušu ventilācija un bullozas plaušu slimības saistītas ar paaugstinātu komplikāciju risku (Ruhl et al., 2011). 
Pleiras dobuma punkcijas visbiežākā komplikācija ir pneimotorakss, kā arī procedūras neizdošanās, sāpes un asiṇošana. Visnopietnākā komplikācija ir orgāna bojājums. Komplikāciju risks ir atkarīgs no ārsta pieredzes un ultrasonoskopijas pieejamības - visaugstākais pneimotoraksa risks ir tad, ja punkciju veic nepieredzējis ārsts bez pirmsprocedūras ultrasonoskopijas - 15\%, turklāt pleiras dobuma drenāža šajos gadījumos ir nepieciešama 4,7\%, šajos gadījumos ir arī visaugstākais punkcijas neizdošanās risks - 12,9\%. Viszemākais pneimotoraksa risks $-2,7 \%$ - ir tad, ja procedūru veic radiologs (Havelock et al., 2010). Interesantu pētījumu veikuši John un kolēǵi (2016), apsekojot slimnīcas, kurās notiek ārstu apmācība un slimnīcas, kurās tā nenotiek, konstatējot, ka apmācīttiesīgajās slimnīcās komplikāciju prevalence pēc pleiras dobuma punkcijām bija augstāka nekā slimnīcās, kuras apmācību neveica.

Pēcaspirācijas pneimotoraksam ir dažādi iemesli - daḷa no tiem noteikti ir saistīti ar plaušas bojājumu, tomēr iespējams arī cits mehānisms - t.s. “ex vacuo” pneimotorakss, kurš izveidojas spiediena samazināšanās ietekmē pacientiem, kuriem pariatālā pleira ir invadēta ar audzēja šūnām - un nav reeksponējama (trapped lung) (Havelock et al., 2010).

Pirms procedūras jābūt veiktam krūšu kurvja rentgenuzṇēmumam. Pēdējās desmitgadēs arvien vairāk tiek uzsvērta pleiras dobuma ultrasonoskopijas noz̄̄me komplikāciju skaita samazināšanā - 2010. gada Britu Torakālās asociācijas pleiras slimību vadlīnijas par invazīiām pleiras manipulācijām un ultrasonoskopiju, balstoties uz B pierādījumu līmeni, stingri rekomendē veikt pirmspunkcijas US vai arī pleiras punkciju veikt US kontrolē, nerekomendējot iepriekšêju "vietas atzīmēšanu" citā telpā vai nodaḷā. Svarīgi arī neveikt pleiras dobuma punkcijas vai citas invazīvas manipulācijas pēc darba laika, izņemot gadījumus, kad šḳidrums pleiras dobumā nosaka elpošanas nepietiekamību, jo ārpus darba laika, it sevišķi, naktīs veiktas manipulācijas ievērojami paaugstina komplikāciju risku (Havelock et al., 2010).

\section{Pleiras punkcijas tehnika}

Pleiras punkcija jāveic sterilos apstākḷos, lai izvairītos no pleiras dobuma infekcijas, kas ir nopietna un novēršama komplikācija. Diagnostiskiem nolūkiem pietiek ar $21 \mathrm{G}$ adatu un 50 ml šlirci parauga savākšanai. Lielāka apjoma satura evakuācijai ir pieejamas dažāda veida punkcijas sistēmas, kas sastāv no adatas, katetra, $50 \mathrm{ml}$ šlirces, trīsvirzienu vārsta un slēgta konteinera šḳidruma savākšanai. Pēdējās desmitgadēs liela izmēra adatas tiek aizstātas ar dažādu veidu katetriem, kurus var ievadīt caur troakāru vai arī izmantot adatu kā stileti, pārvelkot tam pāri katetru un adatu pēc tam evakuējot (Seldingera tehnika). Pleiras punkcija, 
izmantojot katetru, samazina komplikāciju risku un rada mazāku audu bojājumu (Havelock et al., 2010).

Ja vien tas ir iespējams, pacienta stāvoklis punkcijas laikā ir sēdus, rokām atbalstoties pret galdu vai krēsla atzveltni. Pirms punkcijas jāveic US pleiras dobumam un jānosaka vieta, kur ir šķidrums, vislabāk divas ribstarpas zem šḳidruma augšējās līmeṇa un 5-10 cm laterāli no mugurkaula. Āda jāapstrādā ar dezinfekcijas līdzekli. Punkciju sāk ar maza izmēra - 21 G adatu un šlirci ar lidokaīnu (vai citu lokālās anestēzijas līdzekli, ja pacientam ir alerğija pret lidokaīnu). Punkcija jāveic pa apakšējās ribas augšējo virsmu, adatas ceḷā infiltrējot audus ar lidokaīnu. Adata jāvirza uz priekšu, kamēr iespējams iegūt pleiras dobuma saturu. Lai iegūtu pleiras šķidruma paraugu diagnostiskos nolūkos, šliirces ir jānomaina, lai paraugā nebūtu lidokaīna atliekas, bet, ja plānots veikt lielāka daudzuma šķidruma aspirāciju, tad adata jāevakuē un pleiras dobumā anestezētā vietā jāievada aspirācijas sistēma (Ruhl et al. 2011; Havelock et al., 2010).

Joprojām tiek diskutēts par to, cik daudz šķidruma vienā reizē evakuēt ir droši. Kopumā tiek rekomendēts, ka punkcija jāpārtrauc, ja šķidrums vairāk neizdalās, pacientam sākas klepus vai diskomforts aiz krūšu kaula, vai arī ja ir evakuēts 1,5 1 šķidruma (Haveloc et al., 2010). Evakuējot vairāk nekā vienu litru, palielinās simptomātiskas reekspansijas plaušu tūskas risks un evakuējot vairāk kā 1,5 1 šķidruma - pneimotoraksa risks (Ault et al., 2015).

Krūšu kurvja rentgenogrāfija pēc vienkāršas pleiras dobuma punkcijas, kuras laikā nav bijušas komplikācijas vai grūtības, nav indicēta, bet tā noteikti jāveic, ja aspirētajam šḳidrumam ir pievienojies gaiss, bijuši vairāki neveiksmīgi mēginājumi punktēt pleiras dobumu vai ja pacientam pēc punkcijas parādās sūdzības par elpas trūkuma pieaaugumu, sāpēm un ja novēro hemodinamisku nestabilitāti (Havelock et al., 2010).

\section{Torakoskopija}

Torakoskopija ir minimāli invazīva metode, ar kuras palīdzību redzes kontrolē var veikt gan diagnostiskas (pleiras un plaušas biopisjas), gan ārstnieciskas (talka pleirodēze, plaušu daḷu rezekcija, pleiras dobuma sanācija) manipulācijas. Torakoskopija nav jauna metode, pirmo reizi 1910. gadā to veica zviedru internists H.C. Jacobeus pacientam ar eksudatīvu pleirītu, bet loti strauji šì metode kopā ar laparoskopijas metodi sāka attīstīties pēc 1990. gada (RodriguezPanadero et al., 2006).

Literatūrā tiek izşķirtas divu veidu torakoskopijas. Pirmā ir t.s. videoasistētā torakoskopija (VATS), kuru veic torakālie ķirurgi, manipulācijai notiekot vispārējā anestēzijā. Šīs manipulācijas laikā iespējams veikt daudzas dažādas diagnostiskas un ārstnieciskas 
torakālās ķirurǵijas manipulācijas, t.sk., limfmezglu biopsijas, pleiras dekortikācijas, lobektomijas u.c. operācijas. Otrs torakoskopijas veids ir medicīniskā torakoskopija jeb pleiroskopija, kuru var veikt ne tikai ķirurgi, bet arī pneimonologi endoskopiju nodaḷā vietējā anestēzijā ar eventuālu vieglu vispārēju sedāciju galvenokārt diagnostiskos nolūkos (pleiras biopsijas). Medicīniskās torakoskopijas laikā iespējams veikt arī talka pleirodēzi. Tomēr šis iedalījums kḷūst arvien nosacītāks - pneimonologi pēdējos gados arvien vairāk uzlabo savas invazīvo manipulāciju prasmes un veic torakoskopijas ne tikai lokālā anestēzijā un endoskopiju nodạ̣ā, bet arī vispārējā intubācijas narkozē operāciju zālē. Arī manipulāciju skaits, ko veic pneimonologi, ir paplašinājies (pleiras dobuma sanācija pleiras empiēmas gadījumos, simpatektomijas u.tml.). Videoasistētās torakālās ķirurǵijas manipulācijas gan joprojām ir torakālā ḳirurga kompetence (Loddenkemper et al., 2016; Rodriguez-Panadero et al., 2006).

Medicīniskās torakoskopijas indikācijas:

- Neskaidras etiologijijas šķidrums pleiras dobumā;

- Plaušu vēža stadijas precizēšana;

- Mezoteliomas stadijas precizēšana;

- Talka pleirodēze.

Pirmais neskaidras etioloǵijas pleiras šķidruma diagnostiskais solis ir pleiras punkcija ar sekojošu bioḳīmisku pleiras punktāta analīzi. Ja şķidrums ir eksudāts, 20 - 25\% gadījumu tā cēlonis pēc pleiras dobuma punkcijas nekḷūst skaidrs, bet torakoskopijas diagnostiskā precizitāte pēc dažāaiem pētījumiem ir augsta: 60 - 96\%, turklāt pēc biopsijām uzreiz ir iespējams veikt talka pleirodēzi pacientiem ar MPE (Loddenkemper et al., 2016).

Torakoskopijas kontrindikācijas pārsvarā ir relatīvas - stiprs klepus, drudzis, hipoksēmija, koagulācijas traucējumi, nestabila kardiāla patologiija - šie taucējumi iespēju robežās pirms torakoskopijas jānovērš. Absolūta kontrindikācija torakoskopijai varētu būt hroniska obstruktīva plaušu slimība ar elpošanas nepietiekamību un hiperkapniju - šie pacienti netolerē torakoskopijas veikšanai nepieciešamo plaušas kolapsu. Tāpat ḷoti uzmanīgi jāizsver riska un ieguvuma attiecība pacientiem ar pilnīgi obturētu pleiras dobumu, kā arī pacientiem ar intersticiālu plaušu fbrozi ar “bišu šūnu plaušām”. Ja šajos gadījumos izveidojas pneimotorakss pēc plaušas biopsijas, plaušas reekspansijas prognoze ir slikta (Loddenkemper et al., 2016; Rodriguez-Panadero et al., 2006).

Torakoskopijas kopumā ir droša procedūra. Mirstība torakoskopijas rezultātā ir līdzīga mirstībai pēc transbronhiālām plaušu biopsijām - 0,01-0,09\%. Komplikācijas ir retas (vidēji 7,5\% gadījumu) - persistējoša bronhopleirāla fistula, neliela asiṇošana, zemādas emfizēma, 
temperatūra, infekcija un malignu šūnu invāzija brūcē. Dzīvību apdraudošas asiņošanas torakoskopijas laikā vai pēc tās nav aprakstītas (Loddenkemper et al., 2016).

Torakoskopiju var veikt gan ar rigīdu, gan arī ar semifleksiblu torakoskopu caur vienu vai caur divām atverēm krūšu kurvja sienā. Pacienta pozīcija parasti ir guḷus uz sāna. Pirms torakoskopijas pacientam jāizveido arteficiāls pneimotorakss, lai atbrīvotu telpu pleiras dobumā, kurā veikt vajadzīgās manipulācijas - galvenokārt, biopsijas no izmainītiem audiem un talka izsmidzināšanu (Loddenkemper et al., 2016).

Slēgtā pleiras biopsija (closed pleural biopsy) *

Slēgta pleiras biopsija ir metode, kad transtorakāli tiek iegūts parietālās pleiras audu materiāls histologiskai izmeklēšanai. To var veikt ar dažāda veida adatām, piemēram, t.s., Abramsa adatām vai giljotīnas tipa adatām. Slēgta pleiras biopsija dažkārt tiek rekomendēta gadījumos, kad pirmā citologiskā izmeklēšana ir negatīva (malignas šūnas netiek atrastas) un ir būtiska patoloǵiskā procesa histoloǵiskā diagnoze, t.i., MPE un tuberkulozu pleirītu gadījumos (Antunes et al., 2003). Pēc Britu Torakālās asociācijas 2010. gada vienpusēja pleiras šķidruma izmeklēšanas un ārstēšanas vadlīnijām, Abramsa adatas biopsijas rekomendē tikai reǵionos ar augstu tuberkulozes incidenci, bet giljotīnas tipa adatas biopsiijai, it sevišḳi, kombinācijā ar DT ar kontrastvielu izmeklēšanu ir dodama priekšroka sakarā ar augstāko diagnostisko precizitāti (Hooper et al., 2010). Tomēr pēdējā laikā slēgtās adatas biopsijas tiek rekomendētas tikai slimnīcās, kur nav iespējama torakoskopija. Slēgtām adatas biopsijām ir lielāks komplikāciju (asiņošana, pneimotorakss) risks un torakoskopiskai biopsijai salīdzinot ar slēgto adatas biopsiju, ir augstāka diagnostiskā vērtība. Piemēram, histologiiskā diagnoze pēc torakoskopijas tiek noteikta $80 \%$ gadījumu (Valsecchi et al., 2016), bet acidorezistentās baktērijas slēgtās pleiras biopsijas materiālā izdodas izolēt 48\% gadījumu, savukārt torakoskopijas biopsijas materiālā - 76\% gadījumu (Broaddus et al., 2016).

\subsubsection{Laboratoras pleiras šḳidruma izmeklēšanas metodes}

Veiksmīgas pleiras dobuma punkcijas laikā iegūto saturu var novērtēt makroskopiski dzeltens, dzidrs šķidrums var liecināt par transudātu, bet, ja šķidrums ir duḷķains un tam ir brūna, tumši dzeltena, sarkana, zaḷa vai kāda cita krāsa, tas nozīmē, ka pleiras punktāts noteikti ir eksudāts. Tomēr tikai uz makroskopisko novērtējumu paļauties nedrīkst. Ja tiek veikta pirmreizēja pleiras dobuma punkcija, punktāts vienmēr ir jānosūta uz laboratoro izmeklēšanu, turklāt precīzākai diagnostikai ļoti vēlams ir vienlaicīgi ar pleiras punkciju paņemt arī venozo asiņu paraugu tālākai seruma izmeklēšanai. Primārais laboratoro izmeklējumu mērḳis ir atšķirt 
transudātu no eksudāta pēc Laita kritērijiem, tādejādi sašaurinot tālāko diferenciāldiagnostiku un atvieglojot visprecīzāko metožu izvēli.

Laboratoro izmeklējumu minimums ir:

- Laktātdehidrogenāze (LDH) un olbaltumvielas pleiras punktātā (tās jānosaka arī serumā);

- klīniskā izmeklēšana (šūnu skaits un procentuālā attiecība);

- citoloǵiskā izmeklēšana.

Papildus laboratorie testi:

- mikrobioloǵiskā izmeklēšana;

- $\mathrm{pH}$

- glikoze;

- amilāze, lipāze;

- triglicerīdi un holesterīns;

- hematokrīts;

- NT-proBNP (N-terminal pro-brain natriuretic peptide) vai BNP (brain natriuretic peptide)

- adenozīndezamināze;

- polimerāzes ķēdes reakcija Mycobacterium tuberculosis DNS identificēšanai (Broaddus et al., 2016; Hooper et al., 2010).

\section{Olbaltumvielas}

Olbaltumvielu koncenrācija pleiras šķidrumā atkarīga no asinsvadu sieninas un mezotēlija slāṇa caurlaidības - ja caurlaidība ir normāla, olbaltumvielu koncentrācija ir zema, ja tā ir paaugstināta, caurlaidība ir paaugstināta. Klasiski tiek uzskatīts, ka olbaltuma līmenis < $30 \mathrm{~g} / \mathrm{L}$ liecina par transudātu, bet $>30 \mathrm{~g} / \mathrm{L}$ - par eksudātu. Tomēr jāatceras, ka olbaltumvielu koncentrācija pleiras šḳidrumā ir atkarīga no tā koncentrācijas serumā - ja pacientam ir hipoproteinēmija, tad šis skaitlis vairs nav informatīvs. Tāpat olbaltumvielu koncentrāciju pleiras šķidrumā var ietekmēt diurētisko līdzekḷu lietošana - šin̄̄ gadījumā koncentrācija paaugstinās, tādejādi mald̄̄gi liekot uzskatīt šḳidrumu par eksudātu (Hooper et al., 2010). Olbaltumvielu koncentrācija pleiras šķidrumā arī precīzi nenorāda uz konkrētām patoloǵijām, tomēr, ja tā ir ļoti zema $<5 \mathrm{~g} / \mathrm{L}$, tad ir liela iespēja, ka šķidrums ir urinotorakss, peritoneālās dialīzes šḳīdums vai cerebrospinālais šḳidrums (Broaddus et al., 2016). Atšḳirībā no LDH, olbaltuvielu līmenis neko neliecina par procesiem, kas norit pleiras dobuma, tas liecina tikai par to, cik caurlaidīgas ir asinsvadu sieninas (Light R.W., 2013). 


\section{LDH}

LDH ir lielmolekulāra olbaltumviela - oksidoreduktāzes enzīms, kurš katalizē ūdeṇraža pārveidošanos ūdeņraža jonā. Tas satur cinku un piedalās glikolīzes procesā. LDH atrodams visu cilvēka organisma šūnu citoplazmā. Atkarībā no audu un šūnu veida, tajos var atrast dažādus LDH izoenzīmus. Lielākoties LDH aktivitāte audos ir 500-1000 reizes augstāka nekā serumā, bet LDH līmenis serumā būtiski paaugstinās pat neliela audu vai orgānu bojājuma gadījumā.

LDH līmenis serumā visaugstākais ir jaundzimušajiem un bērniem, pieaugušajiem tas nemainās atkarībā no vecuma un dzimuma.

Kopumā LDH ir nespecifisks tests, tā paaugstināts līmenis serumā nenorāda uz kāda konkrēta orgāna bojājumu un nevar kalpot par diagnostisku rīku (Carty et al, 2016), tomēr tā paaugstināts līmenis serumā jau zināmu slimību gadījumos var norādīt uz sliktāku prognozi. Tā piemēram, paaugstināts LDH līmenis serumā tiek minēts kā sliktas prognozes rādītājs nesīkšūnu plaušu vēža (Tuna et al, 2004; Wang et al., 2016), sīkšūnu plaušu vēža (Miao et al., 2016), dzemdes kakla vēža ( $L i$ et al, 2016), augšējo urīnceḷu uroepiteliāla vēža (Zhang et al., 2016), un aizkuṇǵa dziedzera vēža (Faloppi et al., 2015) gadījumos.

LDH seruma līmeṇa izmainas izmanto arī kā ārstēšanas efektivitātes rādītāju pacientiem ar melanomu (Diem et al., 2016) un ne-sīkšūnu plaušu vēzi (Fiala et al., 2016), kā arī kolorektālu vēzi (Passardi et al., 2015).

LDH pleiras dobuma šķidrumā nonāk no seruma filtrācijas ceḷā caur asinsvadu sieniṇu, tās līmenis tādejādi liecina par asinsvadu sieniņas caurlaidību. Tā kā LDH ir intracellulārs enzīms, tad tas var nonākt pleiras dobumā arī no šūnām, tādejādi liecinot par šūnu bojājumu (Broaddus et al., 2016). LDH pleiras šķidrumā šobrīd ir neaizstājams diagnostisks rādītājs pleiras eksudātu un transudātu diferenciāldiagnostikā, tomēr eksudātu etiologiskajā diferencēšanā tam ir maza nozīme. Tāpat arī LDH izoenzīmu noteikšanai ir maza nozīme eksudātu etiologijas noteikšanā. LDH līmenis atspoguḷo iekaisuma aktivitāti pleiras dobumā, tāpēc LDH pleiras punktātā iesaka noteikt katru reizi, kad tiek veikta pleiras dobuma punkcija. Ja LDH līmenis paaugstinās, tad iekaisums palielinās un nepieciešams izmantot agresīvākas ārstēšanas taktikas, savukārt LDH līmeṇa samazināšanās ir pacienta stāvokḷa uzlabošanās rādītājs (Broaddus V.C. et al., 2016).

LDH līmenis pleiras dobumā tiek izmantots arī kā prognostisks markieris malignu pleiras eksudātu diagnostikā - jo augstāks LDH, jo sliktāka prognoze. LDH augstāks par 1500 U/L ir īsākas dz̄ivildzes rādītājs un šiem pacientiem piemērota simptomātiska ārstēšana, savukārt, ja LDH ir zemāks par 1500 U/L, tad dažādu palliatīvu taktiku (pleirodēze, tuneḷa 
katetrs) efektivitāte ir lielāka (Verma et al, 2006). Bielsa et al. (2007) retrospektīvā pētījumā ar 284 iekḷautiem pacientiem konstatējuši, ka, ja LDH bija 140 U/L un 358 U/L robežās, vidējā dzīvildze pacientiem ar malignu pleiras eksudātu bija 11,3 mēneši, bet, ja LDH līmenis bija virs $1025 \mathrm{U} / \mathrm{L}$, vidējā dzīvildze bija vairs tikai 2,8 mēneši.

\section{Laita kritēriji}

Ja pleiras punktātā un serumā ir noteikta LDH un olbaltumvielu koncentrācija, ir iespējams aprēķināt 3 Laita kritērijus:

1. Olbaltums pleiras punktātā / olbaltums serumā $>0,5$;

2. LDH pleiras punktātā / LDH serumā >0,6;

3. LDH pleiras punktātā ir augstāks par 2/3 seruma LDH lokālās laboratorijas normas augšējās robežas.

Ja kaut viens no šiem kritērijiem ir pozitīvs, pleiras šķidrums uzskatāms par eksudātu.

Laita kritēriji pirmo reizi tika publicēti 1972. gadā (Light et al., 2007) un ir pleiras šķidrumu diagnostikas stūrakmens līdz šim brīdim. Pēc Laita kritērijiem diferencē transudātu no eksudāta. Līdz Laita kritēriju atzīšanai transudātu no eksudāta atšķ̄ira, izmantojot tikai olbaltumvielu koncentrāciju pleiras punktātā - $30 \mathrm{~g} / \mathrm{L}$, bet, kā jau minēts, šis līmenis ir atkarīgs no daudziem faktoriem un nevar būt izšķirošais diferenciāldiagnostikā. Oriǵinālajos Laita kritērijos kā trešais kritērijs sākotnēji bija pleiras šķidruma LDH > 200 U/L, tomēr sakarā ar to, ka pastāvēja atšķirības starp dažādām laboratorijām un LDH normālajām vērtībām, 3. kritērijs tika modificēts uz LDH līmeni 24/3 no laboratorijas augšējās LDH normas (Light et al., 2003).

Laita kritēriji ir viltus pozitìvi apmēram 25\% transudātu, tos maldinoši klasificējot kā eksudātus. Lielākoties viltus pozitīvi rezultāti ir pacientiem, kuri saṇem diurētiskos līdzekḷus. Ja pacientam tomēr ir zināma slimība, kuras komplikācija var būt transudāts pleiras dobumā un Laita kritēriji uz eksudāta pusi ir pārsniegti tikai nedaudz, tad jāaprēķina seruma - pleiras šķidruma olbaltumvielu gradients: seruma olbaltumvielu līmenis mīnus pleiras šķidruma olbaltumvielu līmenis. Ja šis gradients ir lielāks par $31 \mathrm{~g} / \mathrm{L}$, šķidrums ar lielāko varbūtību ir transudāts. Ja gradients ir mazāks par 31 g/L, jānosaka vai nu NT-proBNP serumā vai punktātā vai arī albumīna seruma - pleiras punktāta albumīna gradients. Ja Nt-proBNP ir lielāks par 1300 pg/L vai, ja albumīna gradients ir lielāks par 12 g/L, šķidrums ir transudāts (Porcel et al., 2004; Bielsa et al., 2012; Light R.W., 2013). 


\section{Pleiras šḳidruma leikocītu sastāvs}

Pleiras šķidruma šūnu sastāva diferencēšanai veic klīnisko punktāta analīzi, kurai materiāls jānosūta stobriņā ar antikoagulantu, lai novērstu šūnu salipšanu. Normāli pleiras

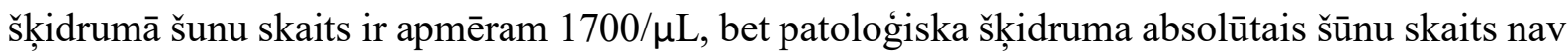
diagnostisks kritērijs. Normālā pleiras šķidrumā atrodas makrofāgi (75 \%) un limfocīti (25\%) (Noppen et al., 2010), bet patologiskā pleiras šķidrumā šūnu attiecības izmainās un tam ir klīniska nozīme diagnozes precizēšanā. Parasti dominē vai nu polimorfnukleārās šūnas (neitrofîlie leikocīti) vai monomorfas nukleārās šūnas (limfocīti). Pirmajā gadījumā vairāk jādomā par akūtu procesu, visbiežāk par parapneimonisku eksudātu, bet otrajā gadījumā parasti process ir hroniskāks (MPE, reimatoīds pleirīts, tuberkulozs pleirīts). Ja ir l̦oti augsts monomorfo nukleāro šūnu procents jauniem cilvēkiem, jādomā par tuberkuloza pleirīta diagnozi (Hooper et al., 2010). Eozinofilijai pleiras šķidrumā parasti nav lielas diagnostiskas nozīmes, un parasti tā ir saistîta ar asiņu vai gaisa (t.sk., jatrogēnas izcelsmes) klātbūtni pleiras šķidrumā (Broaddus et al., 2016).

\section{Citologiiskā pleiras šķidruma izmeklēšana}

Citologiskā izmeklēšana ir ātra un samērā lēta metode, ar kuras palīdzību salīdzinoši mazinvazīvi var konstatēt MPE, tāpēc visiem pacientiem, kuriem pirmo reizi punktēta pleira, pleiras punktāta paraugs jānosūta citologiskai izmeklēšanai. Pēc pētījumu datiem, vidēji $60 \%$ (40-85\%) malignu pleirītu citologiskā izmeklēšanā izdodas atrast malignas šūnas (Hooper et al., 2010). Sākotnēji bija pieņemts, ka, ja pirmais paraugs ir negatīvs, tad citolog̣iskai izmeklēšanai jānosūta vēl 2 paraugi no atkārtotām punkcijām (Jarvi et al., 1972), bet pēdējā laikā tiek uzskatīts, ka vairāki paraugi nepalielina metodes jutību (Hooper et al., 2010). Citoloǵiskās izmeklēšanas jutība ir atkarīga no paraugu lieluma, sagatavošanas un citologa pieredzes - metodes jutība uzlabojas, ja izmeklējamo preparātu sagatavošanai tiek nosūtīti $>60$ ml šķidruma (Swiderek et al., 2010), bet metodes jutîbu vēl vairāk uzlabo imūncitoḳīmiskās metodes, kas palīdz arī diferencēt dažādus audzēju veidus (Fetsch et al., 2001).

\section{Mikrobioloğiskā izmeklēšana}

Neskaidras etioloğijas pleiras šķidrumu iesaka izmeklēt mikrobioloǵiski - gan uz anaerobo, gan anaerobo floru. Vērtīgs izmeklējums ir arī pleiras šķidruma sedimenta krāsošana pēc Grama, kas ir lēts un ātrs, bet ar kura palīdzību var ātri iegūt informāciju par, piemēram, Gr- baktēriju klātbūtni, kas eventuāli varētu mainīt antibakteriālo terapiju. Pleiras šķidruma 
uzsējumu jutība paaugstinās, papildus parastajiem uzsējumiem paredzētiem paraugiem izmantojot asins uzsējumiem domātās barotnes gan aerobiem, gan anaeroiem mikrobiem, tomēr kopumā mikrobioloǵiskās izmeklēšanas jutība ir samērā zema (Broaddus et al., 2016). Pētījumā, kurā tika iekḷauti 259 pacienti ar parapneimonisku pleiras eksudātu, tikai 19,3\% (50 pacientiem) bija pozitīvs mikrobioloǵiskās izmeklēšanas rezultāts. Parauga krāsošana pēc Grama bija pozitīva tikai 14 pacientiem $(5,4 \%)$, turklāt 9 no tiem uzsējumā baktēriijas neauga. Uzsējums bija pozitīvs 41 pacientam (15,8\%). Šie dati ir salīdzināmi arī ar citiem veiktajiem pētījumiem (Jiménez et al., 2006). N̦emot vērā augstās izmaksas un zemo jutību, mikrobiologiisko izmeklēšanu nevajadzētu rutīnas veidā veikt visiem pacientiem ar šḳidrumu pleiras dobumā, it sevišķi, ja pacientam nav norādes par infekciozu procesu. Nākotnes virziens ir polimerāzes ḳēeses rekacijas izmantošana baktēriju identificēšani pleiras punktātā (Broaddus et al., 2016).

\section{pH}

pH samazināšanās pleiras dobuma šķidrumā, visticamāk, ir saistīta ar pienskābes un og̣̣skābās gāzes līmeņa paaugstināšanos.

$\mathrm{pH}<7,20$ var būt dažādu patoloǵiju gadījumā:

- komplicēts parapneimonisks eksudāts;

- barības vada ruptūra;

- reimatoīds pleirīts;

- tuberkulozs pleirīts;

- maligns pleiras seksudāts;

- hemotorakss;

- sistēmiska acidoze;

- sistēmas vilkēde;

- urinotorakss (Broaddus et al., 2016).

Tomēr ar pH mērījumu palīdzību nav iespējams diferencēt šīs slimības savā starpā. pH rekomendē lietot tikai infekciozu nepurulentu pleiras eksudātu gadījumos, lai monitorētu iekaisuma aktivitāti - jo zemāks $\mathrm{pH}$, jo augstāka iekaisuma aktivitāte, turklāt $\mathrm{pH}<$ 7,2 ir indikācija pleiras dobuma drenāžas uzsākšanai (Hooper et al., 2010).

MPE gadījumos zems pH parasti ir sliktas prognozes rādītājs. 417 MPE pacientu metaanalīzē konstatēts, ka vidējā dzīvildze bija 4,0 mēneši un pH ir neatkarīgs prognostisks rādītājs - ja $\mathrm{pH} \leq 7.28$, vidējā dzīvildze bija 2,5 mēneši, bet, ja $\mathrm{pH} \geq 7,28$, vidējā dzīvildze bija 4,5 mēneši (Heffner et al., 2000). 
pH noteikšanai ir ierobežojumi: pirmkārt, jābūt pieejamam arteriālo asiņu gāzu analizatoram tuvu punkcijas telpai, jo materiāls nekavējoties ir jānogādā analīzei. Otrkārt, analizējamais pleiras šķidrums nedrīkst saskarties nedz ar gaisu, nedz arī ar anestezējošo vielu (Hooper et al., 2010), ko ne vienmēr ir vienkārši nodrošināt. Ir konstatēts, ka pleiras šķidruma pH līmenis korelē ar glikozes līmeni - ja pH ir zems, tad arī glikozes līmenis ir zems, līdz ar to, ja nav iespējams nodrošināt kvalitatīvu paraugu paṇemšanu un analīzi, tad pH vietā iesaka lietot glikozi (Broaddus et al., 2016).

\section{Glikoze}

Normāli glikoze brīvi šḳērso asinsvadu sieniṇu un mezotēlija membrānu, līdz ar to glikozes līmenis pleiras šķidrumā ir tāds pats kā asinīs. Zems glikozes līmenis pleiras šķidrumā ir saistīts ar diviem faktoriem - pleiras iekaisuma infiltrātiem, kas neḷauj glikozei brīvi difundēt pleiras šķidrumā un paaugstinātu metabolo procesu (t.sk., baktērijās), kuram nepieciešama glikoze, pleiras šķidrumā (Broaddus et al., 2016).

Zems glikozes līmenis $(\leq 3,5 \mathrm{mmol} / \mathrm{l})$ raksturīgs komplicētiem parapneimoniskiem eksudātiem, empiēmai, reimatoīdam pleirītam, tuberkulozam pleirītam, malignam pleiras eksudātam un barības vada ruptūrai. Reimatoīdā artrīta un pleiras empiēmas gadījumos novēro ļoti zemu glikozes līmeni $\leq 1,6 \mathrm{mmol} / 1$ (Hooper et al., 2010). Parapneimonisku eksudātu gadījumā glikoze $\geq 2,2 \mathrm{mmol} / 1$ norāda uz pleiras dobuma drenāžas nepieciešamību. Pacientiem ar maligniem pleiras eksudātiem ar pozitīvu pleiras citologisko analīzi parasti ir arī zema glikoze (Broaddus et al., 2016).

\section{Amilāze, lipāze}

Amilāze pleiras šķidrumā mēdz būt paaugstināta pacientiem ar barības vada perforāciju, aizkuṇgáa dziedzera slimībām, kā arī MPE gadījumos. Barības vada perforācijas gadījumā amilāze izdalās no siekalu dziedzeriem un caur barības vada plīsumu nonāk pleiras dobumā, savukārt aizkungǵa dziedzera slimību gadījumos amilāze izdalās no aizkungǵa dziedzera. Apmēram 10\% MPE arī ir vidēji paaugstināts amilāzes līmenis, kaut gan primārais audzējs neatrodas aizkungǵa dziedzerī (Broaddus et al., 2016). Tā kā aizkungǵa dziedzera slimības un barības vada ruptūra ir samērā rets pleiras eksudāta cēlonis, tad rutīnas amilāzes izmeklējumi netiek rekomendēti. Lipāze pleiras eksudātā parasti nonāk tikai aizkuṇǵa dziedzera slimību gadījumos, tāpēc tās noteikšana var palīdzēt diagnosticēt šo patologijiju (Hooper et al., 2010). 


\section{Triglicerīdi un holesterīns}

Neskatoties uz to, ka bijuši mēginājumi ar holesterīns un triglicerīdu palīdzību diferencēt transudātu no eksudāta, tomēr ir pierādījies, ka lielas nozīmes šo lipīdu noteikšanai nav. Holesterīna līmenis pleiras šķidrumā ir atkarīgs no tā līmeņa serumā nevis no asinsvadu caurlaidības izmaiņām, turklāt lipīdi, difundējot caur asinsvadu sieniņu, maina struktūru, līdz ar to precīza to noteikšana ir sarežǵīta (Vaz et al., 2001; Light, 2013). Holesterīna noteikšana tiek izmantota hilotoraksa apstiprnāšanai ductus thoracicus plīsuma gadījumā, bet ir dati, ka lipīdu elektroforēze ir labāka diagnostikas metode šajos retajos gadījumos

\section{Hematokrīts}

Hematokrītu ir nozīme noteikt gadījumos, ja pleiras eksudāts ir sangvinozs. Par hemotoraksu liecina pleiras šķidruma hematokrīts, kas lielāks nekā 50\% perifēro asiņu hematokrīta. Hematokrītam, kas mazāks par $1 \%$, nav klīniskas nozīmes. Hematokrīts ir 150 \% mēdz būt MPE, parapneimoniskiem eksudātiem vai pēctraumatiskiem eksudātiem.

\section{NT-proBNP vai BNP}

BNP (brain natriuretic peptide) veidojas miokarda šūnās no prehormona proBNP, tam sadaloties aktīvā BNP un inertā NT-proBNP (NT - N terminal) ekvimolārās koncentrācijas, kas nokḷūst cirkulācijā. BNP un NT-proBNP atbrīvošanos veicina kambaru pildīšanās spiediena paaugstināšanās un sieniṇu iestiepums (Iwanaga et al., 2006; Kinnunen et al., 1993; BrunnerLa Rocca et al., 2001). Laboratoriski iespējams noteikt gan BNP, gan NT-proBNP gan serumā, gan pleiras šķidrumā, tomēr NT-proBNP noteikšana ir dārgāka (Long et al., 2010), bet pētījuma datu par to ir mazāk. Gan NT-proBNP, gan BNP ņemot vērā to rašanās mehānismu, ir jutīgs marḳieris transudātu diagnostikā, it sevišķi gadījumos, kad Laita kritēriji ir viltus pozitīvi par labu eksudātam, tāpat šiem marḳieriem ir augsta jutība kardiālu hidrotoraksu diferencēšanā no citas etiologijas hidrotoraksiem (Broadus et al., 2016; Light et al., 2013).

\section{Adenozīndeamināze (ADA)}

ADA ir aktivētu limfocītu produkts, kas katalizē adenozīna konversiju inozīnā. ADA līmenis pleiras šḳidrumā ir paaugstināts tuberkuloza pleirīta gadījumos, bet nav paaugstināts citu limfocitāru pleiras eksudātu gadījumos (Broaddus et al., 2016). Porcel un kolēǵu 2010. gada pētījumā konstatēja, ka ADA > 35 U/L ir 93\% jutība, 90\% specifiskums un 10,05 pozitīvās izredzes tuberkuloza pleirīta diagnozei limfocitāru eksudātu gadījumos. Tomēr arī vairāk kā 
pusē limfomas izraisītu un 40\% parapneimonisku eksudātu ADA līmenis arī bija augstāks par 35 U/L. Autori konstatēja, ka negatīvā paredzošā vērtība ADA līmeņa noteikšanai ir 99,9\%, kamēr pozitīvā paredzošā vērtība - tikai 7\%, kas nozīmē, ka ADA var izmantot kā jutīgu marḳieri tuberkuloza pleirīta izslēgšanai nevis apstiprināšanai (Porcel et al., 2010).

\section{Polimerāzes ķēdes reakcija Mycobacterium tuberculosis DNS identificēšanai}

Šobrīd ir pieejamas vairākas molekulāras metodes un visizplatîtākā no tām ir polimerāzes ķēdes reakcija mikobaktēriju DNS sekvenču identificēšanai pleiras šķidrumā vai pleiras biopsijas materiālā. Polimerāzes ķēdes reakciju klīniskajos paraugos tomēr limitē zema jutība, kuras izskaidrojums varētu būt DNS degradācija paraugu sagatavošanas gaitā, bet polimerāzes ḳēdes reakcijas specifiskums ir ḷoti augsts (98\%), tāpēc, izmantojot šo metodi, negatīvs rezultāts gan neizslēdz $M$. tuberculosis infekciju, bet pozitīvs rezultāts droši apstiprina M. tuberculosis klātbūtni (Pai et al., 2004).

\section{Audzēja marḳieri}

Audzēja marķieri ir bioḳīmiskas, šūnu, molekulāras vai ǵenētiskas novirzes no normas, kuras izraisa audzēja augšana. Informācija, ko šie marḳieri var sniegt, var būt diagnostiska (sevišķi klīniski nemanifestantiem audzējiem), kas ḷauj diferencēt ḷaundabīgu procesu no labdabīga. Audzēja marķieri var korelēt ar audzēja masu un būt kā prognostiski rādītāji, ḷaujot vadīt un novērtēt ārstēšanu. Dažiem audzēja marķieriem svarīga ir koncentrācija, savukārt citiem - to klātesamība dažādos audos vai šķidrumos.

Ideālam audzēja marḳierim vajadzētu atbilst trīs priekšnosacījumiem:

- marķieri būtu jāizdala tikai vienam konkrētam audzēja tipam;

- jābūt vienkāršai tā audu vai şķidruma parauga iegūšanai, kurā konkrēto marḳieri var noteikt;

- marķiera noteikšanai jābūt ātrai, atkārtojamai un lētai.

Diemžēl, šobrīd nav marḳiera, kas atbilstu visām trīs prasībām (Sanford et al., 2016).

Audzēja marķieri var būt jebkuras cirkulējošas vielas, t.sk., DNS, RNS, olbaltumvielas (enzīmi, seruma olbaltumvielas, metabolīti, receptori, karcinoembrionālās olbaltumvielas, audzēja olbaltumvielas, supresoru gēnu kodētas olbaltumvielas), audzēja šūnas. Audzēja marḳiera koncentrāciju dažādos šķidrumos nosaka audzēja proliferācija, lielums, proteolītiskās aktivitātes audzēja šūnās un nekrotisko šūnu daudzums (Jain et al., 2016).

Audzēja marķieru klasifikācijas var būt dažādas - atkarībā no izcelsmes, struktūras, biolog̣iskās funkcijas un sakarības ar audzēja attīstību vai augšanu (Sharma, 2009). Tā 
piemēram, var izdalīt onkofetālos antigēnus, kuri normāli atrodami augḷa attīstības stadijā, bet nav konstatējami bērnu vai pieaugušo audos vai šķidrumos (alfafetoproteīns, karcinoembrionālais antigēns (CEA); proteīnus, kas rodas epitēlija šūnās un kuri paaugstinās adenomu vai plakanšūnu audzēju gadījumos (CA 19-9; CA 125; CA 15-3), polipeptīdu hormonus, piemēram, horiongonadotropo hormonu un specifiskus enzīmus, piemēram, sārmaino fosfatāzi, kas paaugstinās specifisku audzēju gadījumos (Jain et al., 2016). Bet par audzēja marḳieriem var tikt uzskatītas arī jebkuras citas olbaltumvielas, kas saistītas ar audzēja augšanu, piemēram, laktātdehidrogenāze, C reaktīvais olbaltums, ferritīns, vimentīns u.c. (Sharma, 2009).

Audzēja marķierus var noteikt dažādās vidēs - audos, asinīs, urīnā un serozo dobumu šķidrumos. Pleiras šķidrums, kurš ir iegūstams un izmeklējams tikai patologiijas gadījumā, ir piemērota vide audzēja marķieru noteikšanai, turklāt tieši serozā dobuma šķidrumā marķiera koncentrācija var būt augstāka nekā serumā vai citā vidē. Audzēja markieriem dažādos pētījumos ir augsta jutība citologiski negatīvu MPE gadījumos, turklāt bieži tiek veidoti audzēja marķieru paneḷi, kuru noteikšana jutību paaugstina līdz 90 \% (Pamies et al., 1996). Pēdējos gados gan audzēja marḳieru diagnostiskā nozīme MPE gadījumos mazinās (Feller-Kopman et al., 2018).

\section{Karcinoembrionālais antigēns}

Karcinoembrionālais antigēns (CEA) ir šūnu adhēzijā iesaistīts glikoproteīns, kas tiek izstrādāts embrionālās attīstības laikā. Līdz ar dzimšanu CEA sintēze izzūd, tomēr paaugstinātu tā līmeni konstatē pacientiem ar kolorektālu, aizkungǵa dziedzera, plaušu un krūts dziedzera vēzi, smēḳētājiem, cirozes slimniekiem, ka arī citos gadījumos. CEA līmenis var paaugstināties 4-8 reizes pirms klīnisko simptomu parādīšanās (Nicholson et al., 2014). CEA samērā precīzi tiek noteikts ar imunoloǵiskām izmeklēšanas metodēm. Seruma normālais līmenis ir $\leq 2,5$ $\mathrm{ng} / \mathrm{mL} ; 2,5-5 \mathrm{ng} / \mathrm{mL}$ ir robežlīmenis, bet $\geq 5,0 \mathrm{ng} / \mathrm{mL}$ - paaugstināts līmenis.

Audzēju skrīningam CEA nav izmantojams sakarā ar zemo metodes jutību agrīnās stadijās. Monitorējot audzēju, tā līmenis korelē ar audzēja masu un izplatību. CEA ir neatkarīgs dzīvildzes rādītājs pirms audzēju operācijām - jo augtāks līmenis, jo īsāka dzīvildze un lielāks recidīvu risks (Sanford et al., 2016). 


\section{Vēža karbohidrāta antigēns 125}

Vēža karbohidrāta antigēns 125 (CA 125) ir lielas molekulmasas glikoproteīns. Tas ir atrodams embrijā un mezotēlija audos - vēderplēvē, pleirā, perikardā un amnija apvalkā. Normāli ne augḷa, ne pieaugušā olnīcu epitēlijs neizdala CA 125.

CA 125 nosaka ar imunoloǵiskām metodēm. Augšējā normas robeža ir 35 U/ml. $80 \%$ olnīcu vēža pacientu ir paaugstināts CA 125 līmenis. Tāpat CA 125 līmenis ir paaugstināts pacientiem ar endometrija, dzemdes kakla, plaušu, zarnu un aknu vēzi (Sanford et al., 2016).

CA 125 ir paaugstināts arī labdabīgu slimību gadījumos, piemēram, ascīts un endometrioze, iespējams, tāpēc, ka iesaistīti serozie apvalki un kairinātas mezotēlija šūnas (How et al., 2006).

Ir konstatēts, ka CA 125 līmenis ir atkarīgs arī no hroniskas sirds mazspējas izteiktības. Piemēram, pētîjumā ar 529 stacionētiem sirds mazspējas pacientiem un kontroles grupu - 181 ambulatoru pacientu ar kardiālu patologiju, bet bez sirds mazspējas visiem pacientiem tika veikta ehokardiogrāfija ar kreisā kambara izsviedes frakcijas noteikšanu un noteikts CA 125 līmenis serumā, turklāt pēc 6 mēnešiem pacienti tika atkārtoti apsekoti. Pacientiem ar sirds mazspēju vidējais CA 125 līmenis serumā bija 7 reizes augstāks nekā pacientiem bez sirds mazspējas (105,2 U/L vs 14,9 U/L). 6 mēnešu laikā nomira 89 pacienti un autori konstatēja, ka nāves risks starp 25 un 75 CA 125 līmena percentili pieaug 3 reizes (Núñez et al., 2013).

CA 125 ir zems specifiskums, tāpēc to nevar pilnvērtīgi izmantot olnīcu vēža skrīningam. Pacientiem ar augstāku CA 125 līmeni diagnozes atklāšanas brīd̄̄ ir sliktāka prognoze, bet absolūtie CA 125 līmeņi nekorelē ar audzēja stadiju. CA 125 var veiksmīgi izmantot ārstēšanas kontrolei - daļēja vai pilnīga ārstēšanas efektivitāte $95 \%$ gadījumu ir saistīta ar CA 125 līmeṇa pazemināšanos. CA 125 visbiežāk tiek mērīts asins serumā, bet serozo dobumu šḳidrumu līmeṇi mēdz būt informantīvāki. Normāls vēdera dobuma šḳidruma CA 125 lìmenis ir $\leq 200$ U/L (Korczynski et al., 2009; Sanford et al., 2016;).

Kalantri un kolēgii (Kalantri et al, 2007) analizēja CA 125 nespecifisku paaugstināšanos 38 pacientiem ar pleiras šķidrumu un 46 pacientiem ar ascītu (gan eksudātu, gan transudātu). Tika konstatēts, ka CA 125 bija statistiski nozīmīgi augstāks pacientiem ar jebkuras etioloǵijas ascītu, kas ḷauj izdarīt secinājumus, ka vēdera dobuma mezotēlija šūnām ir lielāka kapacitāte producēt šo vielu.

Literatūrā aprakstītas CEA mediānās vērtības serumā MPE no 3,26-24,9 mg/L, punktātā -7,71-129 mg/L, bet CA 125 mediānās vērtības punktātā - 642-1642 U/mL (Choi et al., 2013; Li et al., 2015; Antonangelo et al., 2015, Son et al., 2015) 


\section{Plazminogēna aktivatora inhibitors 1PAI-1)}

Lai nodrošinātu hemostāzi un nepiel̦autu ne pārāk aktīvu koagulāciju, kas noved pie trombu veidošanās, nedz arī asiņošanu, cilvēka organismā koagulācijas un fibrinolīzes sistēmām jābūt līdzvarā. Fibrinolīze ir fibrīna koagulu enzimātiska degradācija un tās galvenais enzīms ir plazmīns. Fibrinolīzi nosaka lokāla audu plazminogēna aktivatora produkcija endotēlija šūnās bojājuma vietā un plazmā cirkulējošie inhibitori. Fibrinolīzi kavē:

1) PAI-1;

2) $\alpha_{2}$ antiplazmīns;

3) trombīna aktivizējamā fibrinolīzes inhibīcija (TAFI) (3.1. attēls).

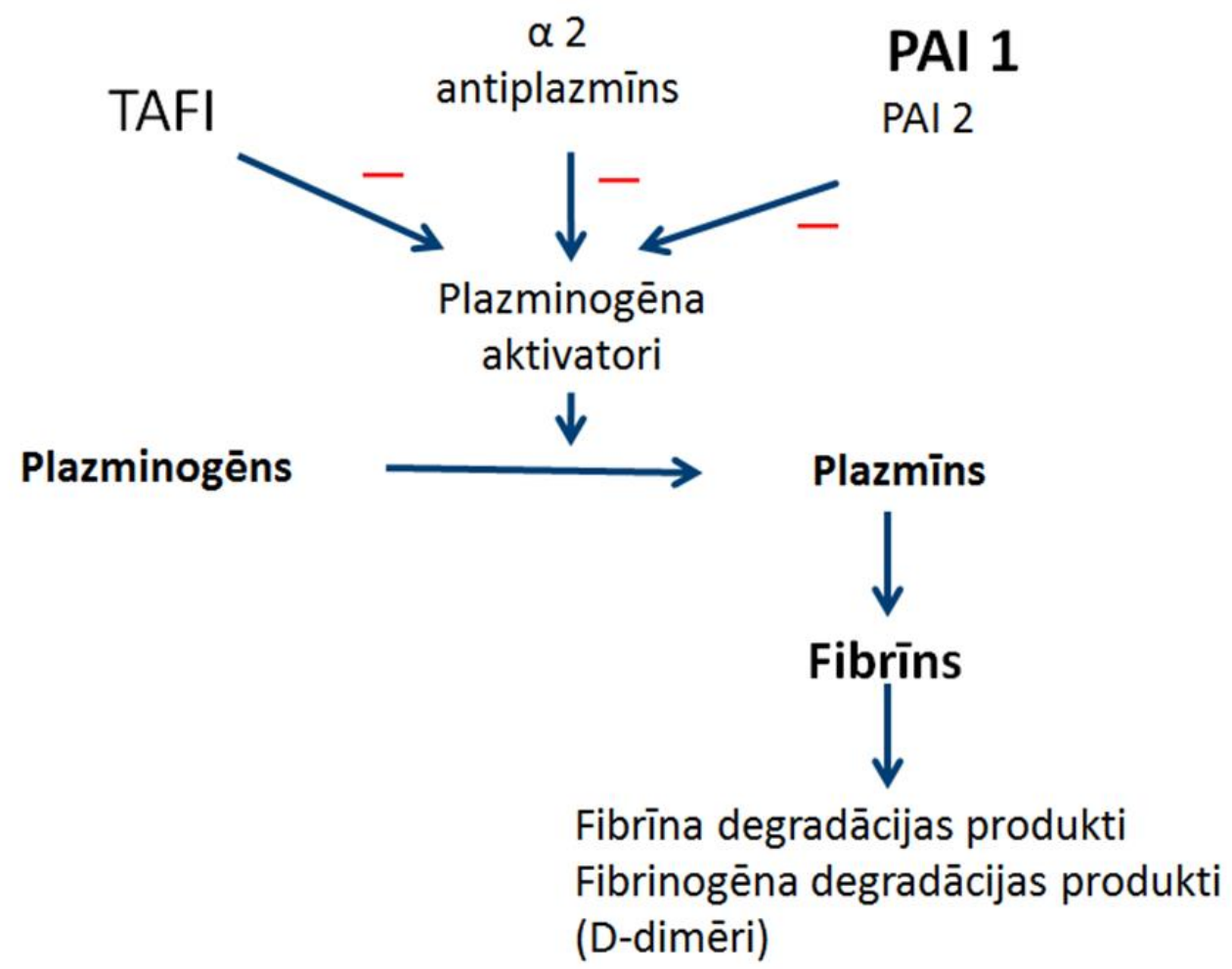

\section{1. att. Fibrinolīzes shematisks attēlojums}

PAI-1 sekretē endotēlija, asinsvadu gludās muskulatūras šūnas, trombocīti, hepatocīti, adipocīit, kā arī audzēja šūnas, tas neatgriezeniski saistās ar audu plazminogēna aktivatoru (tPA), to inaktivējot. $\alpha_{2}$ antiplazmīns ir konstatēts gan brīvā veidā cirkulējošā plazmā, gan arī saistīts ar fibrīnu XIII a faktora darbības rezultātā. $\alpha_{2}$ antiplazmīns arī piesaistās plazmīnam un sašķel̦ to, veidojot inaktivētu plazmīna / $\alpha_{2}$ antiplazmīna kompleksu. Cirkulējošais plazmīns tiek neitralizēts daudz ātrāk nekā pie fibrīna saistītais plazmīns, kurš darbojas fibrinolīzes vietā. 
TAFI regulē koagulāzi un fibrinolīzi. Trombomodulīna klātbūtnē trombīns konvertē

TAFI par TAFI a, kas savukārt sadala fibrīna C termināla lizīnu potenciālajā plazminogēna piesaistīšanās vietā. Rezultātā plazminogēns ir mazāks pieejams plazmīna veidošanai, tādejādi aizkavējot fibrinolīzi.

Fibrinolīzes novērtēšanai tiek izmantoti vairāki testi: trombīna laiks, fibrīna degradācijas produktu, D-dimēru, PAI-1, $\alpha_{2}$ antiplazmīna un plazminogēna noteikšana (Higgins et al., 2013).

Tiek uzskatīts, ka PAI-1 ir ne tikai molekula, kas piedalās fibrinolīzes procesa kavēšanā, bet tam ir arī nozīmīga loma šūnu proliferācijas, adhēzijas, migrācijas regulācijā un signālu transdukcijā, kā arī šūnu proliferācijā un endotēlija un gludās muskulatūras šūnu apoptozē.

Asinsvadu endotēlija šūnu apoptoze ir svarīgs priekšnosacījums asinsvadu remodulācijai - gan fizioloğiskai, gan patologiiskai, t.sk., audzēja angioneoǵenēzei. Šobrīd ir pretrun̄̄gi dati par PAI-1 lomu šajā procesā. Literatūrā minēti gan dati par to, ka tā ir angioğenēzi sekmējoša, gan kavējoša. Iespējams, PAI-1 darbība angioneoğenēzē atkarīga no tā koncentrācijas - zemas PAI-1 koncentrācijas sekmē angioneoǵenēzi antiproteolītiskās aktivitātes dēḷ, bet augsta koncentrācija ir antiangiogēna.

Plazmīns, kuru inhibē PAI-1, katalizē bazālās membrānas un ekstracellulārās matricas degradāciju, potenciāli atvieglojot vēža šūnu iekḷūšanu apkārtējos veselajos audos (Mignatti et Rifkin, 1993), tāpēc varētu sagaidīt, ka plazmīna inhibitors limitēs audzēja augšanu, invāziju un metastāzes, tomēr šobrīd augsts PAI-1 līmenis primāros audzējos ir zināms kā viens no visinformatīvākajiem sliktas prognozes bioḳīmiskajiem marḳieriem it sevišķi krūts vēža pacientiem, līdz ar to proteāžu inhibitoriem nav sagaidāmā antiinvazīvā efekta, tie pat veicina tumora augšanu. Pastāv versijas, ka PAI-1 iesaistās neoangioǵenēzē, saistoties ar olbaltumvielu vitronektīnu, kā arī kavē apoptozi (Rashna et al., 2008). Šobrīd to skaidro ar to, ka ir PAI-1 iedarbība ir atšḳirīga atkarībā no to producējošām šūnām - ja PAI-1 producē audzēja šūnas, tās aizsargā audzēju no apoptozes, tā olbaltumvielas no degradācijas un sekmē tā augšanu (Jänicke et al., 2001). Iespējams arī, ka dažādām PAI-1 koncentrācijām ir pretējs efekts, tāpēc varētu sagaidīt, ka iekaisīga un maligna rakstura eksudātos un transudātos būtu dažādi PAI-1 līmeṇi (Andreasen, 2007).

Konstatēts arī, ka citu patologiisku stāvokḷu gadījumos (diabēts, ateroskleroze, smaga adipozitāte) PAI-1 līmenis plazmā ir l̦oti augsts (Balsara et al., 2008).

PAI-1 prognostiskā nozīme galvenokārt pētīta krūts vēža gadījumos. Pētījumā ar 128 pacienti ar krūts vēzi audzēja audos noteica PAI-1 līmeni, un konstatēja, ka pacientēm, kuru audzēja audos konstatēja PAI-1, bija daudz sliktāka prognoze (Eljuga et al., 2011). 
18 pētījumu metaanalīze ar 8377 krūts vēža pacientēm pierādīja, ka uPA un PAI-1 ir neatkarīgi prognostiski fakori gan pacientēm ar pozitīviem, gan arī pacientēm ar negatīviem regionāliem limfmezgliem (Duffy et al., 2016).

Prospektīvā randomizētā multicentru pētījumā Chemo-NOno no 1993. līdz 1998. gadam tika iekḷautas 674 krūts vēža pacientes ar negatīviem reǵionāliem limfmezgliem. Pacientes tika regulāri apsekotas 5-167 mēnešus. 283 pacientes, kurām audzēja audos bija zems uPA un PAI1 līmenis, tikai novēroja. No 364 pacientēm, kurām audzēja audos bija augsts uPA un PAI-1 līmenis, 242 piekrita randomizācijai - k̦īmijterapija $(n=117)$ vs novērošana $(n=125) .10$ gadu recidīva risks pacientēm bez ķīmijterapijas ar augstu uPA un PAI-1 līmeni gan randomizētā, gan nerandomizētā grupā bija $23 \%$, bet pacientēm ar zemu uPA un PAI-1 līmeni-tikai 12,9 \%. Pacientēm ar augstu uPA un PAI-1, kas saṇēma ķīmijterapiju, bija par 26 \% zemāka iespēja slimības recidīvam nekā tām pacientēm, kuras tikai novēroja. Autori secināja, ka izmantojot uPA un PAI-1 pacientēm ar krūts vēzi un negatīviem reǵionāliem limfmezgliem, var atklāt riska grupu, kurai nepieciešama adjuvanta ķīmijterapija, vienlaicīgi pacientes ar zemu risku nepakḷaut nevajadzīgai ķīmijterapijai.

1995. gada pētījumā 75 pacientiem ar šķidrumu pleiras dobumā, kuriem bija paredzēta torakoskopija, 54 ar MPE un 5 ar labdabīgu šḳidrumu pleiras dobumā veica talka pleirodēzi un pirms torakoskopijas, torakoskopijas laikā 3 un 24 stundas pēc torakoskopijas pleiras punktātā noteica D dimērus un PAI-1. 50 pacientiem pleirodēze bija efektīva un 9 pacientiem tā neizdevās. Tika konstatēts, ka PAI-1 līmenis bija augsts visās pacientu grupās, t.sk, tajā grupā, kurā talka pleirodēzi neveica, bet D dimēru līmenis veiksmīgās pleirodēzes grupā būtiski samazinājās, savukārt neveiksmīgās talka pleirodēzes pacientiem D-dimēru līmenis saglabājās augsts. Autori secina, ka paaugstināta fibrinolītiskā aktivitāte, par kuru liecina D-dimēru līmenis, neskatoties uz augsto fibrinolīzes inhibitora līmeni, ir saistīta ar pleirodēzes neizdošanos (Rodriguez-Panadero et al, 1995).

\section{Jaunāko audzēja biomarḳieru noteikšana pleiras punktātā}

Pēdējos gados medicīnas literatūrā parādās arī ziṇojumi par jaunām molekulām, kuras mēǵina izmantot MPE diagnostikā. Piemēram, imūno šūnu virsmas receptori, ekstracellulārās matrices olbaltumvielas, mesotelīns (Skok K, et al., 2019), kā arī brīvas DNS sekvences pleiras šķidrumā (Husain H et al., 2019). Tomēr pagaidām šo iespējamo molekulu plašāku izmantošanu diagnostikā kavē metožu validācijas trūkums. Katrā ziṇā jaunas molekulas ir plašs jaunu pētījumu lauks. 


\subsection{Pleiras škidruma ārstēšanas metodes}

Pleiras patologijas diagnostikas un ārstēšanas jomā nav daudz pieejamu vadlīniju pēdējā laikā vien̄̄gās ir Amerikas Torakālās Biedrības (American Thoracic Society) 2018. gada Maligna pleiras eksudāta vadības klīniskās prakses vadlīnijas (Feller-Kopman et al., 2018.), pirms tam - Britu Torokālās Biedrības (British Thoracic Society) 2010. gadā izdotās Pleiras slimību vadlīnijas (Du Rand I., Hooper C., MuccDuff A., Roberts M.E., Davies H.E., Rahman N.M., Havelock T. et al.,). Vēl literatūrā tiek pieminētas arī 2014. gada spāṇu Pleiras šķidruma diagnostikas un ārstēšanas rekomendācijas (Villena Garrido et al., 2014).

\subsubsection{Transudāta ārstēšana}

Jebkura pleiras šķidruma diagnostikas pamatā ir transudāta un eksudāta diferencācija. Visbiežāk transudāts pleiras dobumā ir hroniskas sirds mazspējas dekompensācijas pazīme un pacientam novēro sirds mazspējas dekompensācijas simptomus - elpas trūkumu, ortopnoji, perifēras tūskas, sastrēgumu mazajā asinsrites lokā rentgenologiiski un samazinātu kreisā kambara izsviedes frakciju ehokardiogrāfiski (Broaddus et al., 2016). Precīzi kritēriji, kad pēc klīniskās ainas var noteikt, vai škiidrums pleiras dobumā ir transudāts, nav formulēti, tomēr ja ir zināma sirds slimība un novērojami iepriekš minētie simptomi, tad pleiras punkcija nav nepieciešama un jāuzsāk sirds mazspējas dekompensācijas ārstēšana. Izṇēmumi ir gadījumi, ja pacientam ir sāpes pleiras šķidruma pusē vai ja pacientam ir paaugstināta temperatūra. Ja pēc dažām dienām šķidrums pleiras dobumā ir mazinājies vai izzudis, jāturpina sirds mazspējas ārstēšana un tālāka iespējamas pleiras dobuma pataloǵijas izmeklēšana un ārstēšana nav nepieciešama (Broaddus et al., 2016; Villena Garrido et al., 2014; Hooper et al, 2010). Līdzīgi ir ar citas ǵeneēzes transudātiem - pirmā izvēle ir konservatīva pamatslimības (aknu maspējas dekompensācijas, nieru mazspējas dekompensācijas) ārstēšana (Broaddus et al., 2016).

\subsubsection{Parapneimoniska pleirīta ārstēšana}

Par parapneimoniska pleirīta ārstēšanu ir pieejami daudz plašāki pētījumi kā par transudātu ārstēšanu.

Parapneimoniska pleirīta ārstēšanas galvenie uzdevumi ir uzsākt adekvātu antibakteriālu terapiju un evakuēt eksudātu no pleiras dobuma. Tāpat jānodrošina adekvāta pacienta barošana, lai izvairītos no hipoalbuminēmijas un jārūpējas par dziḷo vēnu trombozes profilaksi (Villena Garrido et al., 2014; Hooper et al, 2010). 
Antibakteriālā terapija jāsaṇem visiem pacientiem, ņemot vērā lokālās antibakteriālās terapijas vadlīnijas (pierādījumu līmenis B). Antibakteriālie līdzekḷi, kas ir efektīvi pret anaerobo floru, jādod visiem pacientiem, izṇemot tos, kuriem pleiras punktāta uzsējumā pierādīta Streptococcus pneumoniae infekcija (pierādījumu līmenis B). Makrolīi parapneimoniskiem pleirītiem netiek rekomendēti, izṇemot gadījumus, kad ir pamatotas norādes par atipiskas floras iesaisti patologiiskajā procesā (pierādījumu līmenis B). Ja vien iespējams, antibakteriālā terapija jākorig̣ē pēc mikrobiologiiskās atbildes saṇemšanas (pierādījumu līmenis B). Penicilīni, penicilīni plus klavulānskābe, metronidazols un cefalosporīni labi penetrē pleiras dobumā, bet jāizvairās no aminoglikozīdiem (pierādījumu līmenis B). Sākotnēji antibiotikas jāievada intravenozi, bet, kad sasniegta stabila uzlabošanās, var pāriet uz perorālu antibiotiku lietošanu, kas var būt ilgstoša arī pēc pacienta izrakstīšanās no slimnīcas (Hooper et al., 2010). Antibakteriālās terapijas izvēlē jāṇem vērā tas, vai parapneimonisks pleirīts ir sadzīvē iegūts vai hospitāls, pacienta vispārējais stāvoklis un blakusslimības (pierādījumu līmenis B) (Villena Garrido et al., 2014).

Pleiras eksudāta evakuācija jāveic visiem pacientiem ar pneimonijas vai sepses klīniku un šḳidrumu pleiras dobumā (pierādījumu līmenis B) (Hooper et al., 2010). Svarīgi veikt ultrasonogrāfiju pirms pleiras dobuma punkcijas, lai noteiktu, vai šķidrums pleiras dobumā ir brīvs vai norobežots. Ja pleiras dobumā redzams septēts šķidrums, vai arī ja šķidruma $\mathrm{pH}>7,2$ (vai glikoze < $6 \mathrm{mmol} / \mathrm{l}$ vai LDH > $1000 \mathrm{U} / \mathrm{L}$ ), indicēta pleiras dobuma drenāža. Pārējos gadījumos pietiekama ir pleiras satura vienreizēja vai atkārtota aspirācija (Villena Garrido et al., 2014). Pleiras dobuma drenāžas indikācijas ir arī strutas pleiras dobumā (B pierādījumu līmenis), mikrobiologiski identificētas baktērijas pleiras dobuma šķidrumā (pierādījumu līmenis B). Pleiras dobuma drenas izmērs var būt arī neliels (10-14 G), var tikt izmantoti arī neliela diametra fleksiblie katetri, ja tos regulāri skalo (pierādījumu līmenis C) (Hooper et al., 2010).

Britu vadlīnijas neiesaka fibrinolītisko līdzekḷu instillāciju pleiras dobumā (pierādījumu līmenis A) pierādījumu trūkuma dēḷ (Hooper et al., 2010), bet spāṇu vadlīnijas atzīmē, ka fibrinolītisko līdzekḷu ievadīšana ir droša procedūra ar mazu komplikāciju risku un vienīgo kontrindikāciju - bronhopleirālu fistulu (Villena Garrido et al., 2014). Pēdējā laikā arvien vairāk parādās publikācijas, kas atbalsta intrapleirālo fibrinolītisko līdzekḷu lietošanu komplicēta (norobežota) parapneimoniska pleirīta gadījumos. Tā piemēram, Aleman ar kolēǵiem veica prospektīvu pētījumu 99 pacientiem ar komplicētu parapneimonisku pleirītu vai pleiras empiēmu, randomizējot visus 3 grupās, no kurām 1 grupa saṇēma 20 mg alteplāzes vidēji 3 reizes, otra $-10 \mathrm{mg}$ alteplāzes vidēji 3 reizes un trešā $-100000 \mathrm{D} / \mathrm{V}$ urokināzes vidēji 
3 reizes. Autori konstatēja, ka ķirurǵiska iejaukšanās bija nepieciešama tikai 1 (3\%) pacientam no alteplāzes grupām un $2(4$ \%) no urokināzes grupas. Nopietna asiņošana tika novērota 5 (28\%) pacientiem no $20 \mathrm{mg}$ alteplāzes grupas un 4 (12\%) pacientiem no $10 \mathrm{mg}$ alteplāzes grupas, bet nevienam pacientam no urokināzes grupas (Aleman et al., 2015). Arī pediatrijas praksē Shirota un Uchida, apkopojot 4 pētījumus, kuros salīdzināta intrapleirāla fibrinolīze ar VATS, konstatējuši, ka fibrinolīze ir mazinvazīvāka, drošāka un lētāka procedūra komplicētu parapneimonisku pleirītu un pleiras empiēmas ārstēšanai kā VATS (Shirota et al., 2015). Tāpat veiktas 2 metaanalīzes ( 7 pêtījumi, kuros tika iesaistīts 801 pacients, un 10 pêtîjumi, kuros tika iesaistīti 977 pacienti), kurās tika secināts, ka intrapleirāla fibrinolīze samazina nepieciešamību pēc ķirurğiskas ārstēšanas, kā arī nav novērotas nopietnas blaknes (Janda et al., 2012; Nie et al., 2014). Pēdējā laikā tiek pētīti arī citi aǵenti, ko lietot fibrinolītisko enzīmu vietā. Prospektīiā dubultaklā placebokontrolētā pētījumā 220 pacientiem ar inficētu pleiras dobuma šḳidrumu pleiras dobumā ievadīja dezoksiribonukleāzi vai audu plazminogēna aktivatoru vai dezoksiribonukleāzi un audu plazminogēna aktivatoru vai placebo, un konstatēja, ka dezoksiribonukleāze un audu plazminogēna aktivators uzlaboja šḳidruma drenāžu un samazināja nepieciešamību pēc ķirurgiskas iejaukšanās (Rahman et al., 2011).

Torakoskopija ir metode, kuras laikā minimāli invazīvi var atdalīt saaugumus, evakuēt šķidrumu, ievietot pleiras dobuma drenu redzes kontrolē, tomēr nav lielu randomizētu pētījumu, lai precizētu torakoskopijas vietu parapneimoniska pleirīta ārstēšanā. Ja pleiras drenāžu nevar panākt ar torakoskopijas palīdzību, nepieciešama torakotomija ar atvērto pleiras drenāžu vai bez tās (Girdhard et al., 2012).

\subsubsection{MPE ārstēšana}

MPE parasti nozīmē audzēja disemināciju un šajos gadījumos radikāla ārstēšana nav iespējama. Tomēr, ņemot vērā to, ka parasti MPE ir recidivējošs un tā daudzums ir liels, kas pacientam izraisa grūti tolerējamu elpas trūkumu, nepieciešama pēc iespējas efektīvāka paliatīva un simptomātiska ārstēšana, lai maksimāli uzlabotu pacienta dzīves kvalitāti un mazinātu vai likvidētu simptomus.

MPE gadījumā ir iespējamas dažādas taktikas:

- $\quad$ novērošana;

- $\quad$ pleiras dobuma punkcija (terapeitiskos nolūkos);

- drenas ievadīšana ar sekojošu sklerozanta instilāciju pleiras dobumā;

- $\quad$ torakoskopija ar pleirodēzi;

- $\quad$ pastāvīga tuneḷkatetra ievietošana; 
- $\quad$ ķīmijterapija jutīgiem audzējiem pēc indikācijām.

Novērošana iespējama pacientiem, kuriem nav simptomu un kuru audzēja veids ir zināms. Tomēr parasti simptomi parādās samērā ̄̄sā laikā un ir nepieciešama kāda no tālākām tehnikām.

Terapeitiska pleiras dobuma punkcija - parasti pēc tās pirmā mēneša laikā atkal uzkrājās šķidrums pleiras dobumā, tāpēc šāda metode ieteicama tikai tad, ja prognozējamā dzīvildze ir mazāk kā viens mēnesis. Pirmajā aspirācijas reizē nerekomendē evakuēt vairāk kā 1,5 1 šķidruma (Hooper et al., 2010).

Ja prognozējamā dzīvildze ir lielāka par mēnesi, tālākā taktika atkarīga no tā, vai plauša ir sarukusi, t.i., vai uz viscerālās pleiras ir izveidojušies audzēja un fibrīna sakopojumi, kas neḷauj plaušai izplesties. Sarukušas plaušas gadījumā pleirodēze ir neefektīva sakarā ar to, ka plauša nesaskaras ar krūšu kurvja dobuma sienu un nepieciešams ievadīt pastāvīgu tuneḷveida katetru, ar kuru pacients var doties arī mājās un kura aprūpi var iemācīt pacientam vai piederīgajiem. Ja ir skaidrs, ka plauša nav sarukusi (pēc punkcijas vai drenāžas novērojama piln̄̄ga izplešanās), ir apsverama pleirodēze (Hooper et al, 2010; Feller-Kopman et al., 2018).

Pleirodēze ir manipulācija, kuras laikā rada apstākḷus saaugumiem starp viscerālo un parietālo pleiru, tādejādi obliterējot dobumu, kurā uzkrājas šķidrums. Pleirodēzi var veikt dažādos veidos - ar k̦īmiskiem sklerozantiem (piemēram, bleomicīns vai tetraciklīns) vai arī veicot pleiras abrāziju torakoskopijas laikā.

Izvēles medikaments pleirodēzei ir sterils talks (4-5 g). Eksistē divi dažādi veidi, kā ievadīt talku. Talku var ievadīt suspensijas veidā caur drenu un to var insuflēt sausā veidā torakoskopijas laikā caur torakoskopu (t. s. talka "pūderēšana”) (Hooper et al., 2010).

Talka pleirodēzi caur drenu (rekomendē maza izmēra drenas - 10-14 F) parasti veic pēc tam, kad no pleiras dobuma ir evakuēts viss saturs un rentgenologiski ir konstatēts, ka plauša ir izpletusies. Pirms procedūras pacients ir jāatsāpina (rekomendē izvairīties no nesteroīdiem pretiekaisuma līdzekliem, jo tie var kavēt aseptiskā iekaisuma veidošanos un līidz ar to fibrīna izgulsnēšanos), pleiras dobumā caur drenu ievada lidokaīnu - $3 \mathrm{mg} / \mathrm{kg}$, maksimāli $250 \mathrm{mg}$, pēc tam 4 līdz 5 grami sterila talka, kas sajaukts ar $50 \mathrm{ml}$ sterila fiziologisiskā šḳiduma. Drenu uz 2 stundām slēdz, pēc tam atver, l̦auj izdalīties eksudātam un evakuē pēc 24-48 stundām. Talka pleirodēzei caur drenu ir vairākas priekšrocības, kā arī vairāki trūkumi - nav nepieciešama pacienta sedācija torakoskopijas laikā, un to var izdarīt nodaḷā nevis operāciju zālē caur drenu, kas ievadīta, lai evakuētu maligno eksudātu, turklāt tā ir lētāka. Tomēr talka izgulsnēšanās pleiras dobumā ir nevienmērīga, kā arī nav iespējams vienlaicīgi paṇemt biopsiju, lai verificētu diagnozi. 
Talka pleirodēzi torakoskopijas laikā veic operāciju zālē vai endoskopiju nodaḷā vispārējā sedācijā, retāk - lokālā anestēzijā pēc pilnīgas šķidruma evakuācijas redzes kontrolē pleiras dobumā izsmidzinot sausu talku. Pirms tam, ja nepieciešams, iespējams paņemt biopsijas no izmainītajām pleiras zonām diagnozes apstiprināšanai. Torakoskopiskas talka pleirodēzes priekšrocības ir vienmērīgāka talka izgulsnēšanās pleiras dobumā, iespēja paṇemt biopsijas un atdalīt iespējamos saaugumus labākai talka ievadīšanai. Tomēr šai metodei lielākoties nepieciešama vispārēja sedācija, pacientam jābūt spējīgam nodrošināt adekvātu oksigenāciju ar vienu plaušu, tā kā torakoskopijas laikā nepieciešams izveidot arteficiālu pneimotoraksu. turklāt ne visur torakoskopija ir pieejama. Tāpat šī metode ir arī dārgāka.

Viedokḷi par to, kāda metode ir labāka, ir pretrun̄̄gi. Britu un Amerikas torakālās biedrības vadlīnijās teikts, ka talka pleirodēze caur drenu ir tikpat efektīva kā talka pleirodēze torakoskopijas laikā. Spāṇu vadlīnijas uzskata, ka, ja pieejama torakoskopija, tad pleirodēze būtu jāveic tās laikā, pleirodēzi caur drenu atstājot gadījumiem, kad pacienta vispārējais stāvoklis nav piemērots torakoskopijai (Villena Garrido et al., 2014; Hooper et al, 2010; Dresler et al., 2005; Feller-Kopman et al., 2018).

2005. gadā veiktajā prospektīvā randomizētā pētījumā ar 501 randomizētu pacientu par talka pleirodēzi caur drenu vs. talka pleirodēzi torakoskopijas laikā pacientus randomizēja 2 vienlīdzīgās grupās. Pēc tam, kad pārliecinājās par plaušas pilnvērtīgu izplešanos, torakoskopiju veica 177 pacientiem, bet pleirodēzi caur drenu - 163 pacientam. 25 pacienti (14\%) nomira 30 dienu laikā pēc torakoskopijas, bet 33 pacienti $(20 \%)$ - pēc pleirodēzes caur drenu. Izdzīvojušie pacienti pēc 30 dienām tika atkārtoti apsekoti. Efektivitātē nebija statistiski ticamas atšķirīibas starp abām grupām - sekmīga torakoskopiska pleirodēze bez šḳidruma atkārtotas uzkrāšanās tika konstatēta $64 \%$ pacientu, bet pēc pleirodēzes caur drenu - $57 \%$ $(\mathrm{p}=0,177)$ (Dresler et al., 2005).

Divdesmit pētījumu metaanalīzē tika apkopoti salīdzinoši pētījumi par talka pleirodēzi gan caur drenu, gan arī torakoskopiski, kas tika salīdzināta ar dažādiem citiemsklerozējošiem aǵentiem: povidonjodu, mustīnu, tetraciklīnu, bleomicīnu, doksiciklīnu, sudraba nitrātu, dažos pētījumos salīdzinājumam tika izmantota arī mehāniskā pleirodēze un pastāvīgais tuneḷveida katetrs vai arī salīdzināta talka pleirodēze caur drenu ar talka pleirodēzi torakoskopijas laikā. Novērošanas laiks bija no 1 līdz vairākiem mēnešiem. Pētījumi tika sadalīi grupās atkarībā no talka ievadīšanas veida un tika konstatēts, ka torakoskopiska talka pleirodēze bija efektīvāka salīdzinot ar visām citām lokālām terapijām (RR 1,74; 95 \% CI, 1,11-2,73; p = 0,015), savukārt talka ievadīšanai caur drenu nebija statistiski būtiskas priekšrocības salīdzinājumā ar citām pleirodēzes metodēm (RR 1,05, 95 \% CI, 0,87-1,27; p=0,588). Tika salīdzināts arī talks ar 
citiem sklerozējošiem aǵentiem un metodēm un noskaidrots, ka talka pleirodēze bija efektīvāka par bleomicīna pleirodēzi, bet salīdzinot ar citām metodēm statistiski būtiskas atšķirības nebija. Tāpat tika konstatēts, ka vislabākie rezultāti tika sasniegti pacientēm krūts vēzi. Kā blakus parādības minētas drudzis, sāpes, brūces infekcija (Xia et al., 2014).

Pleirodēzes indikācijas nav strikti definētas, tā ir indicēta pacientiem, kuriem ir MPE un prognozējamā dzīvildze $>1$ mēnesi pie nosacījuma, ka nav sarukusi plauša. Spāṇu vadlīnijas iesaka izmantot Karnofsky indeksu (Timmerman, 2013), lai izšķirtu, kuriem pacientiem veikt torakoskopiju, kuriem talka pleirodēzi caur drenu (Villena Garrido et al., 2014; Hooper et al, 2010).

2014. gadā publicēts lielākais prospektīvais pētījums par MPE pacientu prognozi. Šinī pētījumā validēta riska stratifikācijas sistēma, kas piemērota izmantošanai klīniskajā praksē, izvēloties ārstēšanas taktiku, t.sk., izvērtējot pleirodēzes indikācijas. Autori izmantojoši 3 lielas starptautiskas MPE pacientu kohortas (kopā 789 pacienti no Austrālijas, Nīderlandes un Lielbritānijas datu bāzēm) un apkopojuši 14 riska faktorus prognostiskā punktu skalā un nosaukuši to par LENT prognostisko skalu (abreviācija veidota no šādiem vārdiem: pleiras šķidruma Laktātdehidrogenāze; Austrumu (E्astern) kooperatīvā onkolog̣ijas grupas funkcionālā stāvokḷa skala (ECOG PS), Neitrofilo leikocītu/limfocītu attiecība asin̄̄s un audzēja (Tumor) tips) (3.1. tabula). Skala tika validēta, analizējot 76 pacientus no Lielbritānijas kohortas, kuriem bija visi nepieciešamie dati. Izmantojot šo skalu, pacientus var iedalīt zema riska, vidēja riska un augsta riska grupā ar vidējo dzīvildzi attiecīgi 319; 130 un 44 dienas.

Pastāvīgo tuneḷa katetru ievieto pacientiem, kuriem ir īsa prognozējamā dzīvildze vai augsts risks, neizdevusies pleirodēze, kā arī pacientiem, kuriem ir sarukusi plauša un pleirodēze nav iespējama. Ir dati, ka ilgstoša katetra atrašanās pleiras dobumā stimulē pleiras iekaisumu un vakkuuma pudeles, kas tiek pievienotas šīm sistēmām, sekmē plaušas izplešanos, līdz ar to notiek pleiras dobuma obliterācija, t. i., spontāna pleirodēze līdz pat 42 \% pacientu. Arī slimnīcā pavadīto dienu skaits ir daudz mazāks salīdzinot ar pleirodēzes veikšanai nepieciešamo (Villena Garrido et al., 2014; Hooper et al, 2010). 
LENT skala (Clive et al., 2014)

\begin{tabular}{|c|c|c|}
\hline Rādītājs & Novērtējums & Punkti \\
\hline \multirow{2}{*}{ LDH pleiras punktātā } & $<1500 \mathrm{U} / \mathrm{L}$ & 0 \\
\hline & $>1500 \mathrm{U} / \mathrm{L}$ & 1 \\
\hline \multirow{4}{*}{ ECOG PS (Oke net al., 1982) } & 0 & 0 \\
\hline & 1 & 1 \\
\hline & 2 & 2 \\
\hline & $3-4$ & 3 \\
\hline \multirow{2}{*}{$\begin{array}{l}\text { Neitrofilo leikocītu / limfocītu } \\
\text { attiecība }\end{array}$} & $<9$ & 0 \\
\hline & $>9$ & 1 \\
\hline \multirow{3}{*}{ Audzēja tips } & $\begin{aligned} & \text { Zemāka riska audzēji } \\
&- \text { Mezotelioma } \\
&- \text { Hematoloǵiska slimība } \\
&\end{aligned}$ & 0 \\
\hline & $\begin{aligned} & \text { Vidēja riska audzēji } \\
&- \text { Krūts audzējs } \\
&- \text { Ginekologisks audzējs } \\
&- \text { Nieru audzējs }\end{aligned}$ & 1 \\
\hline & $\begin{array}{l}\text { Augsta riska audzējs } \\
\begin{aligned}- & \text { Plaušu vēzis } \\
- & \text { Citi audzēji }\end{aligned}\end{array}$ & 2 \\
\hline
\end{tabular}

LENT skalas riska sadalījums:

- $\quad$ zems risks: 0-1 punkti;

- vidējs risks: 2-4 punkti;

- $\quad$ augsts risks: 5-7 punkti.

3.2. tabula

ECOG PS skala

\begin{tabular}{|c|l|}
\hline 0 & Pilnībā aktīvs, var nodarboties ar visām aktivitātēm kā pirms slimības \\
\hline 1 & $\begin{array}{l}\text { Ierobežots augstas slodzes aktivitātēs, bet ambulators un spējīgs darīt darbu, kas prasa } \\
\text { mazu piepūli (mājas darbi, biroja darbs) }\end{array}$ \\
\hline 2 & $\begin{array}{l}\text { Ambulators, ir saglabātas pašaprūpes spējas, bet nevar strādāt. Kustās vairāk apmēram } \\
50 \% \text { nomoda stundu. }\end{array}$ \\
\hline 3 & Spējīgs uz ierobežotu pašaprūpi, gul vai sēž vairāk nekā $50 \%$ nomoda stundu. \\
\hline 4 & Nav pašaprūpes spēju. Piesaistīts gultai vai krēslam pilnībā. \\
\hline 5 & Miris \\
\hline
\end{tabular}

\subsection{Maligna pleiras eksudāta aktualitāte no veselības aprūpes sistēmas viedokḷa}

Neskatoties uz precīzu epidemiologísko datu neesamību, visā pasaulē MPE novērtēts kā būtisks saslimstības un mirstības cēlonis, turklāt lielākā daḷa pacientu palīdzības sniegšanai tiek hospitalizēti atkārtoti, kas saistīts ar pacienta dzīves kvalitātes būtisku pasliktināšanos un veselības aprūpes izmaksu pieaugumu (Taghizadeh $N$ et al., 2016). Kaut gan ārstēšanas iespējas ir ierobežotas un parasti tiek veikta pacienta paliatīvā aprūpe, pēdējos 15 gados arvien vairāk 
pētījumos tiek analizēta audzēju molekulārā biologija un biomarḳieru nozīme ātras, izmaksu ziṇā efektīvas un minimāli invazīvas diagnostikas nodrošināšanā, kas sekmētu savlaicīgu MPE diagnostiku un ļautu izmantot iespējamās ārstēšanas metodes agrīni, līdz ar to uzlabojot pacienta dzīves kvalitāti un mazinātu veselības aprūpes izmaksas, kas saistītas ar pacientu atkārtotu stacionēšanu (Penz E et al., 2017; Psallidas et al., 2016; Feller-Kopman et al., 2018). 


\section{MATERIĀLS UN METODES}

Pētījuma protokols apstiprināts RSU Ētikas komitejā. Pētījums veikts SIA Rīgas Austrumu kl̄̄niskās universitātes slimnīcas stacionārā "Gailezers".

Lai noskaidrotu, cik pacientu ar šķidrumu pleiras dobumā gada laikā tiek ārstēti SIA RAKUS Stacionāra “Gaiḷezers" iekšķīgo slimību nodaḷās, retrospektīvi analizētas to pacientu medicīniskās kartes, kuri no 2010. gada 1. janvāra līdz 2010. gada 31. decembrim ārstējušies un izrakstīti vai miruši no RAKUS slimnīcas "Gaiḷezers” iekšķīgo slimību profila nodaḷām Gastroenterologijas, Pulmonoloǵijas, Kardioloǵijas, Endokrinoloǵijas, Iekšķ̄īgo slimību, Nefrologiijas, Aritmologijijas, Nieru aizstājterapijas nodaḷām. Atlasītas medicīniskās kartes, kurās izrakstǐšanās diagnozē bija norādes par šķidrumu pleiras dobumā. Atlasītās medicīniskās kartes analizētas pēc orǵināli izveidotas shēmas (sk. 4.1. tabulu).

Lai noskaidrotu papildus bioḳīmisko un onkoloğisko marķieru nozīmi MPE diagnostikā, prospektīvi tika analizēti no 08.08.2011. līdz 13.06.2014. Rīgas Austrumu klīniskās universitātes slimnīcas stacionāra "Gaiḷezers" Iekšḳ̂̄go slimību klīnikas Pulmonologiijas nodaḷā secīgi stacionēti pacienti ar škiidrumu pleiras dobumā.

4.1. tabula.

\section{Slimības vēsturu izvērtēšanas shēma}

\begin{tabular}{|l|l|}
\hline Nr. p.k. & Parametrs \\
\hline 1. & Nodalass profils \\
\hline 2. & Gultasdienu skaits \\
\hline 3. & Stacionēšanas mēnesis \\
\hline 4. & Dzimums \\
\hline 5. & Vecums \\
\hline 6. & Vai pacients izrakstīts dzīvs vai miris? \\
\hline 7. & Kurā krūšu kurvja pusē konstatēts škidrums? \\
\hline 8. & Vai veikta krūšu kurvja rentgenogramma? \\
\hline 9. & Krūšu kurvja rentgenogrammas atrade \\
\hline 10. & Vai veikta datortomogrāfija plaušām? \\
\hline 11. & Vai veikta US pleiras dobumam? \\
\hline 12. & Vai veikta pleiras dobuma punkcija? \\
\hline 13. & Kurā dienā pēc iestāšanās veikta pleiras dobuma punkcija? \\
\hline 14. & Cik reizes veikta pleiras dobuma punkcija? \\
\hline 15. & Vai veikta kl̄̄niskā pleiras dobuma škidruma analīze? $?$ \\
\hline 16. & Ja jā, kāds ir leikocītu sastāvs? \\
\hline 17. & Vai noteikts pleiras dobuma LDH? \\
\hline 18. & Ja jā, kāds ir rezultāts? \\
\hline 19. & Vai noteikts olbaltumvielu līmenis pleiras punktātā? \\
\hline 20. & Ja jā, kāds ir rezultāts? \\
\hline 21. & Vai pleiras dobuma škidrums nosūtīts uz citoloğisko analīzi? \\
\hline 22. & Ja jā, vai konstatēta malignitāte? \\
\hline 23. & Vai pleiras škidrums izmeklēts bakteriologiski? \\
\hline 24. & Ja jā, kāds ir rezultāts? \\
\hline 25. & Kādi papildizmeklējumi ir veikti? \\
\hline
\end{tabular}


4.1. tabulas nobeigums

\begin{tabular}{|l|l|}
\hline Nr. p.k. & \multicolumn{1}{|c|}{ Parametrs } \\
\hline 26. & Kāda ir pamatdiagnoze izrakstǐšanās brīdī? \\
\hline 27. & Kāda ir pleiras šķidruma etioloğija pēc diagnozes izrakstīšanās brīdī? \\
\hline 28. & Kādi ir primārie audzēji MPE gadījumā? \\
\hline
\end{tabular}

Iekḷaušanas kritēriji:

- rentgenologiski un ultrasonsokospiski konstatēts šķidrums pleiras dobumā;

- diagnostiskas un/vai terapeitiskas indikācijas pleiras dobuma punkcijai;

- parakstīta informētā piekrišana iegūto datu iekḷaušanai pētījumā.

Par pleiras dobuma punkcijas indikācijām tika uzskatītas šādas pazīmes:

1) neskaidras etiolog̣ijas šķidrums pleiras dobumā, tostarp aizdomas par MPE;

2) parapneimonisks pleirīts, tostarp aizdomas par empiēmu pacientiem ar akūtu slimību, febrilu temperatūru, paaugstinātiem iekaisuma rādītājiem (CRO līmenis) un pneimonijas rengenologisko ainu;

3) liela apjoma šķidrums pleiras dobumā elpas trūkuma mazināšanai (Huggins et al., 2011; Roberts et al, 2010; Havelock et al., 2010).

Pētījumā netika iekḷauti:

- atkārtoti stacionēti pacienti ar šķidrumu pleiras dobumā;

- pacienti ar dekompensētu sirds mazspēju (iepriekš diagnosticēta sirds slimība anamnēzē, progresējošs elpas trūkums, perifēras tūskas, sirds mazspējas pazīmes ehokardiogrammā (ehoKG), sastrēgums mazajā asinsrites lokā krūšu kurvja rentgenogrammā) un kardiālu hidrotoraksu, kuriem nebija ne diagnostisku, nedz arī terapeitisku indikāciju pleiras dobuma punkcijai.

Pleiras dobuma punkcija tika izdarīta pēc pacienta informētās piekrišanas pleiras dobuma punkcijai saņemšanas lokālā anestēzijā ar Sol. Lidocaini $2 \%$, izmantojot Pleurocan (Braun) pleiras dobuma katetrus. Visu pacientu pleiras dobuma šķidruma paraugi tika nosūtīti uz laboratoriju, lai analizētu šādus parametrus:

- Citologiskās punktāta analīzes:

○ Leikocìtu sastāvs (neitrofilo leikocītu un limfocītu procentuālais sastāvs, hematokrīts);

○ citoloǵiskā analīze (ḷaundabīgu šūnu esamība);

- Bioḳīmiskās analīzes:

○ LDH;

○ olbaltumvielas; 

○ BNP;
○ PAI 1.

- Onkologisko marḳieru analīze:

○ CEA;

○ CA 125;

Visiem pacientiem vienlaicīgi ar pleiras dobuma punkciju tika veikta perifērās vēnas punkcija un paņemti venozie asins paraugi sekojošu parametru noteikšanai:

- LDH;

- olbaltumvielas;

- BNP;

- PAI-1.

- onkoloǵisko marķieri;

○ CEA;

○ CA 12 ;

LDH un olbaltumvielu noteikšanai pleiras šķidrums un venozās asinis tika savāktas stobrinos bez antikoagulanta un nosūtītas uz RAKUS Laboratoriskās medicīnas centru Stacionārā "Gaiḷezers”. Olbaltumvielas noteiktas ar kolorimetrisko metodi. LDH noteikta ar kinētisko ultravioleto metodi. Pēc rezultātu saṇemšanas ar mērḳi iedalīt pleiras šḳidrumus transudātos un eksudātos tika aprēḳināti Laita kritēriji (Light et al, 2007):

1) olbaltums pleiras punktātā / olbaltums serumā $>0,5$;

2) LDH pleiras punktātā / LDH serumā > 0,6;

3) LDH pleiras punktātā ir > par 2/3 seruma LDH lokālās laboratorijas normas (LDH normas augšējā robeža RAKUS Laboratorijas centrā = 240 U/L) - >160U/L.

Pleiras punktāta klīniskā analīze tika savākta EDTA stobriṇā un nosūtīta uz RAKUS Laboratorijas centru klīniskai analīzei (manuāli šūnu skaitīšana zem mikroskopa un automatizētā metode):

- gaismas mikroskopā saskaitot 200 šūnas un nosakot limfocītu un neitrofīlo leikocītu (granulocītu un agranulocītu) procentuālo attiecību;

- ar automatizētām metodēm nosakot polimorfo nukleāro un monomorfo nukleāro leikocītu procentuālo sastāvu, kā arī hematokrītu un hemoglobīna līmeni.

Citoloǵiskai analīzei $30 \mathrm{ml}$ pleiras šķidrums sterilā traukā tika nosūtīts uz RAKUS Laboratoriskās medicīnas centru citologiskai izmeklēšanai.

Pacientiem ar akūta slimību, febrilu temperatūru, paaugstinātiem iekaisuma rādītājiem (CRO līmenis) un pneimonijas rengenologisko ainu tika veikts pleiras punktāta uzsējums. 
Audzēja marḳieru noteikšanai pleiras šḳidrums un venozās asinis tika savāktas stobriņos bez antikoagulanta, 35 minūtes nostādināti un centrifugēti 10 minūtes ar 3000 rpm, no pleiras škidruma atdalīts supernatants un no asinīm - serums, tie sasaldēti $-80{ }^{\circ} \mathrm{C}$ temperatūrā līdz analīzes veikšanai. CA 125 un CEA tika noteikti ar ELISA (enzyme-linked immunosorbent assay) metodi ar Abbot Architect analizatoru saskaņā ar ražotāja protokolu.

BNP noteikšanai pleiras punktāts un asinis tika savāktas EDTA stobriņā un nosūtītas uz RAKUS Laboratorijas centru. BNP līmenis tika noteikts ar hemiluminiscences mikrodalinu imūnķīmisko analīzi (CMIA).

PAI-1 noteikšanai venozās asinis un pleiras šķidrums tika savākts stobriṇos bez antikoagulanta, 45 minūtes nostādināti un centrifugēti $10 \mathrm{~min}$. ar $1000 \mathrm{rpm}$. Supernatants un serums tika atdalīts un sasaldēts $-80^{\circ} \mathrm{C}$ temperatūrā līdz analīzes veikšanai. PAI-1 tika noteikts ar citometrisko xMAP tehnoloǵiju (Luminex iekārta) Rīgas Stradiṇa universitātes Cilvēka bioḳīmijas un fiziologijas katedrā.

Kardiāls hidrotorakss tika diagnosticēts pacientiem ar iepriekš diagosticētu sirds slimību, sirds mazspējas pazīmēm (perifêra tūska, zināma sirds slimība anamnēzē, sirds mazspējas pazīmes ehoKG vai venozs sastrēgums krūšu kurvja rentgenogrammā) un hipoksēmiju zem $93 \% \mathrm{SpO}_{2}$, kura būtiski nelabojās pēc papildus skābekḷa pievades. Parapneimonisks pleirīts tika diagnosticēts pēc šãdiem kritērijiem: akūta slimība ar klepu, febrilu temperatūru, paaugstinātiem iekaisuma rādītājiem (CRO līmenis) un atbilstošu rentgenoloǵisko atradi. Maligns pleiras eksudāts (MPE) tika diagnosticēts, pamatojoties uz citologisko pleiras punktāta izmeklēšanu. Ja citoloğiskā izmeklēšana bija negatīva, eksudāts tika uzskatīts par MPE arī gadījumos, ja pacientam bija jau iepriekš pierādīta maligna slimība un netika konstatēts cits eksudāta cēlonis (Sahn, 1998). Pacientiem, kuriem klīniskajā pleiras šķidruma analīzē monomorfo nukleāro šūnu skaits bija > $95 \%$, tika veikta slēgtā pleiras biopsija. Tuberkuloza pleirīta diagnoze sākotnēji tika pierādīta ar pleiras biopsijas histoloǵisko izmeklēšanu, atrodot specifiskas izmaiņas - epiteloīdšūnu granulomas ar kazeozu nekrozi, apstiprinot tās ar bioptāta bakteriologisko izmeklēšanu (uzsējumu acidorezistento baktēriju pierādīšanai). Pleirīts, saistīts ar pankreatītu, tika diagnosticēts pēc paaugstināta lipāzes līmeṇa pleiras šķidrumā.

Pacientiem ar MPE, kuriem bija indicēta talka pleirodēze un kuri parakstīja informētās piekrišanas veidlapu pirms tās veikšanas, tika veikta talka pleirodēze caur drenu ar $4 \mathrm{~g}$ talka suspensijas un $40 \mathrm{ml} \mathrm{0,9 \%} \mathrm{NaCl} \mathrm{šķīdumu,} \mathrm{pievienojot} 10 \mathrm{ml} 2 \%$ Lidokaīna šķīdumu. Drena tika slēgta uz 2 stundām un evakuēta pēc tam, kad 2 dienas izdalījās mazāk nekā 100 ml škiidruma. 


\subsection{Statistiskās analīzes metodes}

Visu datu statistiskie aprēḳini tika veikti ar SPSS (abreviatūra no angḷu valodas Statistical Package for the Social Sciences) for Windows programmas 23.0 versiju un MS Excel 2007. Atbilstoši vispārpieņemtajiem principiem medicīnas statistikā p vērtība 0,05 tiek uzskatīta par divpusējo testu rezultātu statistiskās ticamības slieksni. Personu grupu raksturošanai tika izmantotas vispārpieņemtās statistikas metodes (Teibe, 2007; Dawson, 2001; Altman, 1997). Kvantitatīvo datu sadalījuma atbilstība normālajam pārbaudīta, izmantojot histogrammas un Kolmogorova-Smirnova testu. Tā kā datu sadalījums neatbilda normālajam sadalījumam, vidējo rādītāju raksturošanai tika izmantota mediāna, 25. un 75. percentile. Kategoriskie jeb kvalitatīvie main̄̄gie tika raksturoti ar procentuālo proporciju. Lai iegūtos rezultātus varētu vispārināt pētāmajai populācijai, tika aprēķinātas $95 \%$ ticamības intervāla robežas. Divu neatkarīgu grupu salīdzināšanai izmantots Manna-Vitnija (Mann-Whitney) testu, jo main̄̄gie neatbilda normālajam sadalījumam. Kategorisko main̄̄go salīdzināšanai dažādās grupās izmantots Pīrsona (Pearson) hī $\chi 2$ tests, veikta arī kontinuitātes korekcija pēc Jeitsa (Yates) metodes un aprēķinātas arī izredžu attiecības (odds ratio, OR). Lai noteiktu dažādu testu jutību un specifitāti, tika izmantotas ROC (abreviatūra no angḷu valodas - receiver operating charasteristic) līkne, aprēķinot zemlīknes laukumu. 


\section{REZULTĀTI}

\subsection{Retrospektīvi iegūto datu analīze}

\subsubsection{Pacientu raksturojums}

Retrospektīvi analizējot medicīniskās kartes, konstatēts, ka no RAKUS Stacionāra “Gaiḷezers” iekšḳīgo slimību profila laika posmā no 2010. gada 1. janvāra līdz 2010. gada 31. decembrim izrakstīti 14838 pacienti, un šajās nodaḷās miris 741 pacients.

No visu pacientu stacionāra medicīniskām kartēm atlasītas 716 (4,6 \%) ar izrakstīšanās diagnozē minētu jebkuras etioloǵijas šķidrumu pleiras dobumā. No šiem pacientiem 615 $(85,9 \%)$ izrakstīti, $101(14,1 \%)$ - miris. Kopējā mirstība stacionārā bija 4,4\%.

No analizētajiem pacientiem 337 (47 \%) bija vīrieši un 379 (53\%) sievietes vecumā no 18 līdz 98 gadiem (5.1. attēls). Apsekoto pacientu sadalījums pēc vecuma ir unimodāls, modālais vecums 71 līdz 80 gadi. Saslimušo skaita palielināšanās notiek vecumā virs 40 gadiem - vecuma grupās $\operatorname{lidz} 41$ gadam ir tikai 4,2\% no izlasē iekḷautajiem pacientiem, bet pārejās vecuma grupās ir 95,8 \% pacientu. Vidējais pacientu vecums analizētajā gadā stacionārā kopā bija 58,3 gadi.

Nav konstatētas statistiski nozīmīgas saslimušo sieviešu un vīriešu skaita atškiirības $\left(\chi^{2}=2,464 ; \mathrm{p}=0,117\right)$.

Miruši 41 vīrietis un 60 sievietes. Visvairāk mirušo ir vecuma grupā no 71 līdz 90 gadiem - 59 (58,4 \% no visiem mirušajiem). 


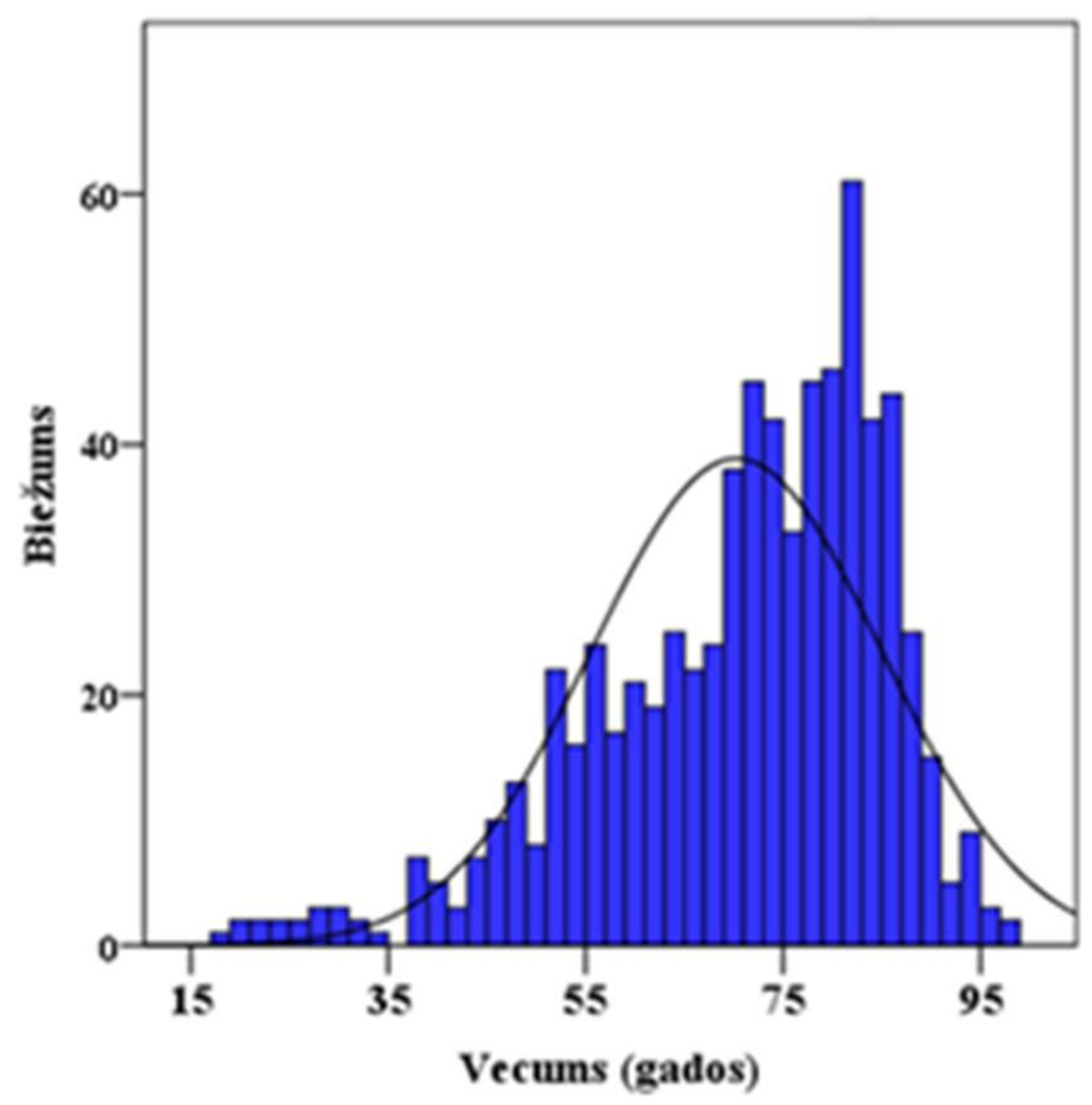

5.1. att. Pacientu (n = 716) ar šḳidrumu pleiras dobumā sadalījums pēc vecuma

Visvairāk pacientu stacionēti janvārī (66-9,2 \% no visiem pētījuma pacientiem), martā (77-10,8\% no visiem pētījuma pacientiem), septembrī (74-10,3\% no visiem pētījuma pacientiem) un oktobrī (72-10,1 \% no visiem pētījuma pacientiem). Savukārt jūlijā stacionēto pacientu skaits ir vismazākais - 39 (5,4\% no visiem pētījuma pacientiem). Jūlijā stacionēto pacientu skaita atšķirības no jūnijā stacionēto pacientu skaita ir statistiski nozīmīgas $\left(\chi^{2}=53,824 ; p=0,000\right)$, bet atškirīibas no augustā stacionēto pacientu skaita nav statistiski nozīmīgas $\left(\chi^{2}=2,723 ; p=0,099\right)$ (5.2. attēls).

Pacienti stacionārā pavadījuši vidēji 13 dienas. 1 dienu stacionārā pavadījuši 10 pacienti, savukārt 18 pacienti slimnīcā atradušies vairāk par 30 dienām. 


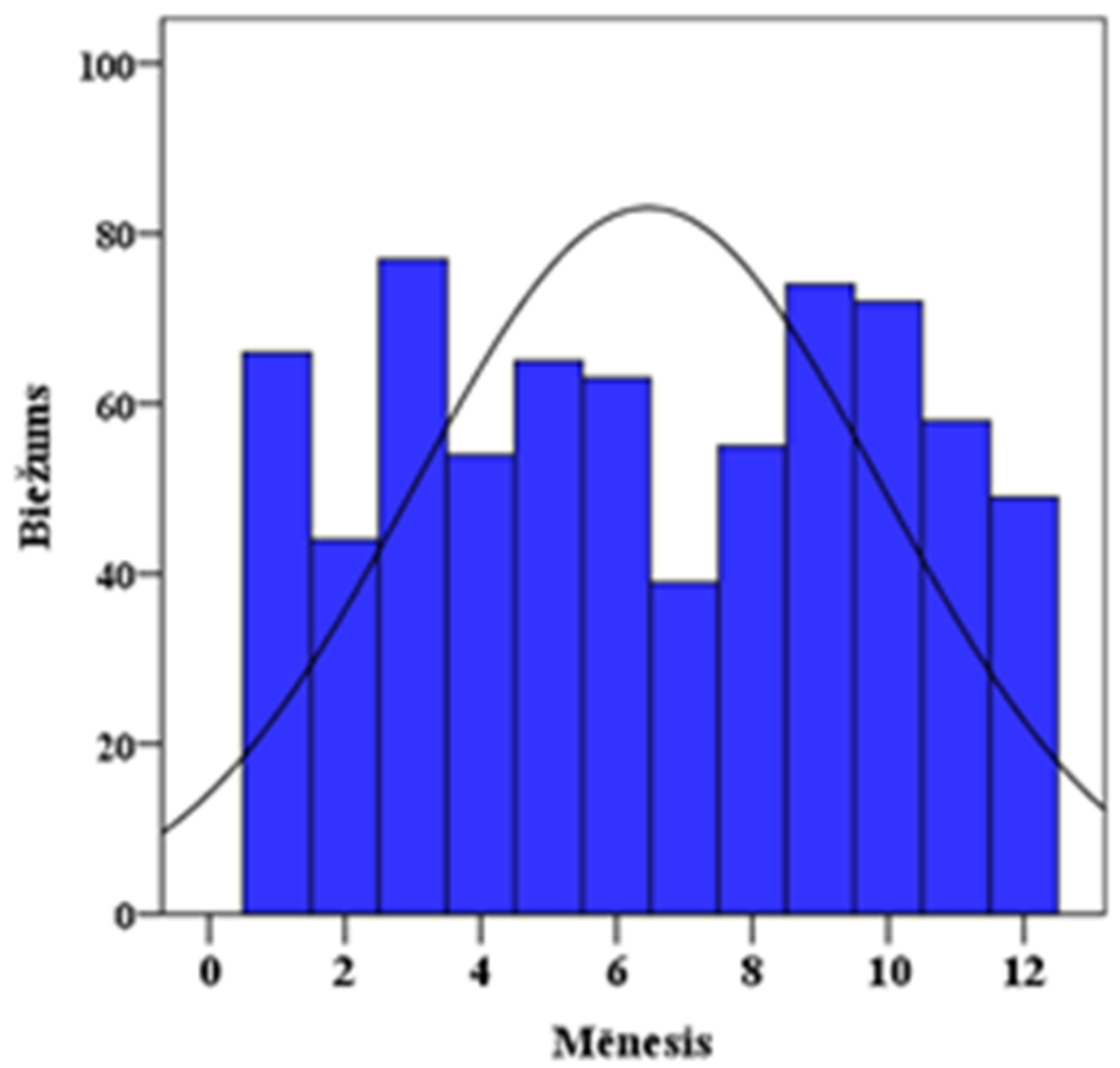

5.2. att. Pacientu $(n=761)$ iedalījums atkarībā no stacionēšanas mēneša

\subsubsection{Izmeklējumu rezultāti un diagnozes}

Izvērtējot izrakstī̌sanās diagnozes, 312 (43,6 \%) pacientiem šķidrums bija labās puses pleiras dobumā, $110(15,4 \%)$ - kreisās puses, 224 (31,3\%) - abpusējs un 70 (9,8\%) pacientiem pleiras dobuma šķidruma lokalizācija nebija precizēta.

Analizējot medicīniskajās kartēs dokumentētos izmeklējumus pacientiem ar šķidrumu pleiras dobumā, 651 (90,9 \%) pacientam stacionārā bija veikta krūšu kurvja rentgenogrāfija, 11 pacientiem $(1,5 \%)$ tā bija veikta ambulatori, bet 54 pacientiem $(7,5 \%)$ - netika veikta. 167 $(23,3 \%)$ pacientiem bija veikta krūšu kurvja datortomogrāfija. Analizējot abus šos izmeklējumus kopā, 155 pacientiem (21,6\%) bija veikta gan rentgenogrāfija, gan datortomogrāfija. 494 pacientiem $(68,9 \%)$ bija veikta tikai rentgenogrāfiska izmeklēšana, 11 pacientiem $(1,5 \%)$ - tikai datortomogrāfija, 42 pacientiem $(5,9 \%)$ netika veikta ne rentgenogrāfija, ne datortomogrāfija. 141 gadījumā (19,7 \% no visiem pētījuma pacientiem) medicīniskajā kartē bija dokumentēta pleiras dobuma ultrasonogrāfija (5.3. attēls). No šiem 
pacientiem 104 bija veikta pleiras dobuma punkcija, 37 pleiras dobuma punkcija netika veikta. 407 pacientiem (56,8 \% no visiem pētîjuma pacientiem) medicīniskajā kartē nebija norādes par pleiras dobuma ultrasonogrāfijas veikšanu un nebija veikta pleiras dobuma punkcija. 168 pacientiem (23,5\% no visiem pacientiem) bija veikta pleiras dobuma punkcija, bet nebija minēta pleiras dobuma ultrasonogrāfija (5.1. un 5.2. tabula).

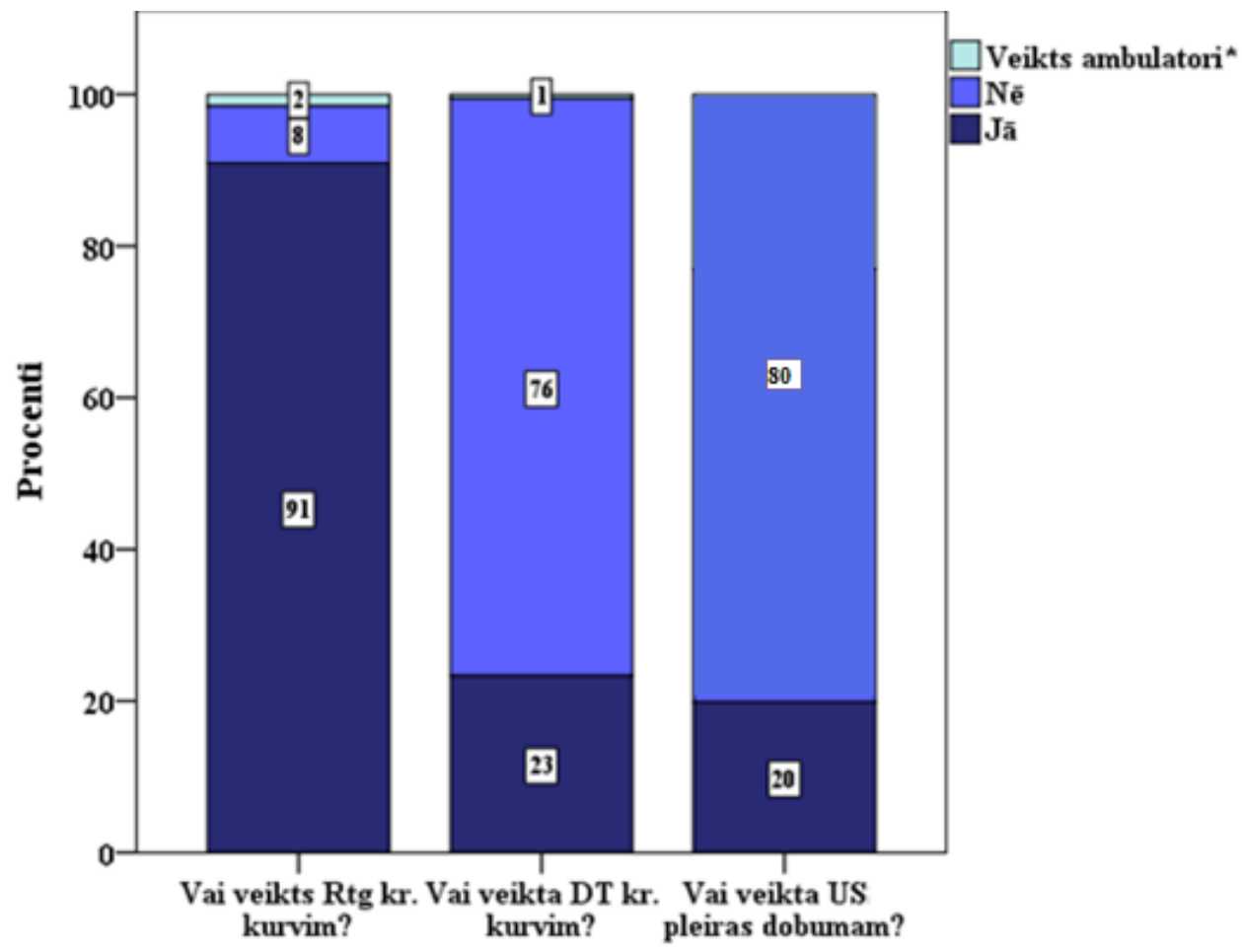

5.3. att. Attēldiagnostikas izmeklējumi pacientiem ar

5.1. tabula

Pacienti, kuriem veikta US pleiras dobumam un pleiras dobuma punkcija

\begin{tabular}{|l|c|c|c|}
\hline \multirow{2}{*}{ Vai veikta pleiras US? } & \multicolumn{2}{|c|}{$\begin{array}{c}\text { Vai veikta pleiras dobuma } \\
\text { punkcija? }\end{array}$} & \multirow{2}{*}{ Kopāa } \\
\cline { 2 - 3 } & $\mathbf{J a}$ & $\mathbf{N} \overline{\mathbf{e}}$ & \\
\hline $\mathrm{Ja}$ & $104(14,5 \%)$ & $37(5,2 \%)$ & $141(19,7 \%)$ \\
\hline $\mathrm{N} \overline{\mathrm{e}}$ & 0 & $407(56,8 \%)$ & $407(56,8 \%)$ \\
\hline Nav precizēts & $168(23,5 \%)$ & 0 & $168(23,5 \%)$ \\
\hline Kopā & $272(38 \%)$ & $444(62 \%)$ & $716(100 \%)$ \\
\hline
\end{tabular}


Izrakstītie un mirušie pacienti, kuriem tika veikta pleiras dobuma punkcija

\begin{tabular}{|l|c|c|c|}
\hline \multirow{2}{*}{ Pacienti } & \multicolumn{2}{|c|}{ Vai veikta pleiras dobuma punkcija? } & \multirow{2}{*}{ Kopā } \\
\cline { 2 - 3 } & $\mathbf{J a}$ & $\mathbf{N e}$ & \\
\hline Miris & $23(3,2 \%)$ & $78(10,9 \%)$ & $101(14,1 \%)$ \\
\hline Izrakstīts & $249(34,8 \%)$ & $366(51,1 \%)$ & $615(85,9 \%)$ \\
\hline Kopā & $272(38 \%)$ & $444(62 \%)$ & $716(100 \%)$ \\
\hline
\end{tabular}

71 pacientam (26,1 \% no punktētajiem) pirmā pleiras punkcija veikta pirmajā - t. i., iestāšanās dienā, 53 (19,5 \% no punktētajiem) - 2. dienā, 26 (9,6 \% no punktētajiem) - 3. dienā, 25 (9,2 \% no punktētajiem $)$ - 4. dienā, 20 pacientiem $(7,4 \%$ no punktētajiem) pleiras punkcija veikta 7. dienā. Jāatzīmē, ka bija arī pacienti, kuriem pirmā pleiras punkcija bija veikta 14.-30. dienā pēc iestāšanās (5.4. attēls). 169 (23,6 \%) pacientiem bija veikta viena pleiras dobuma punkcija. $76(10,6 \%)$ pacientiem - 2 punkcijas. Trīs punkcijas bija veiktas 16 pacientiem $(2,2 \%)$. Četras un vairāk punkcijas bija veiktas 11 pacientiem.

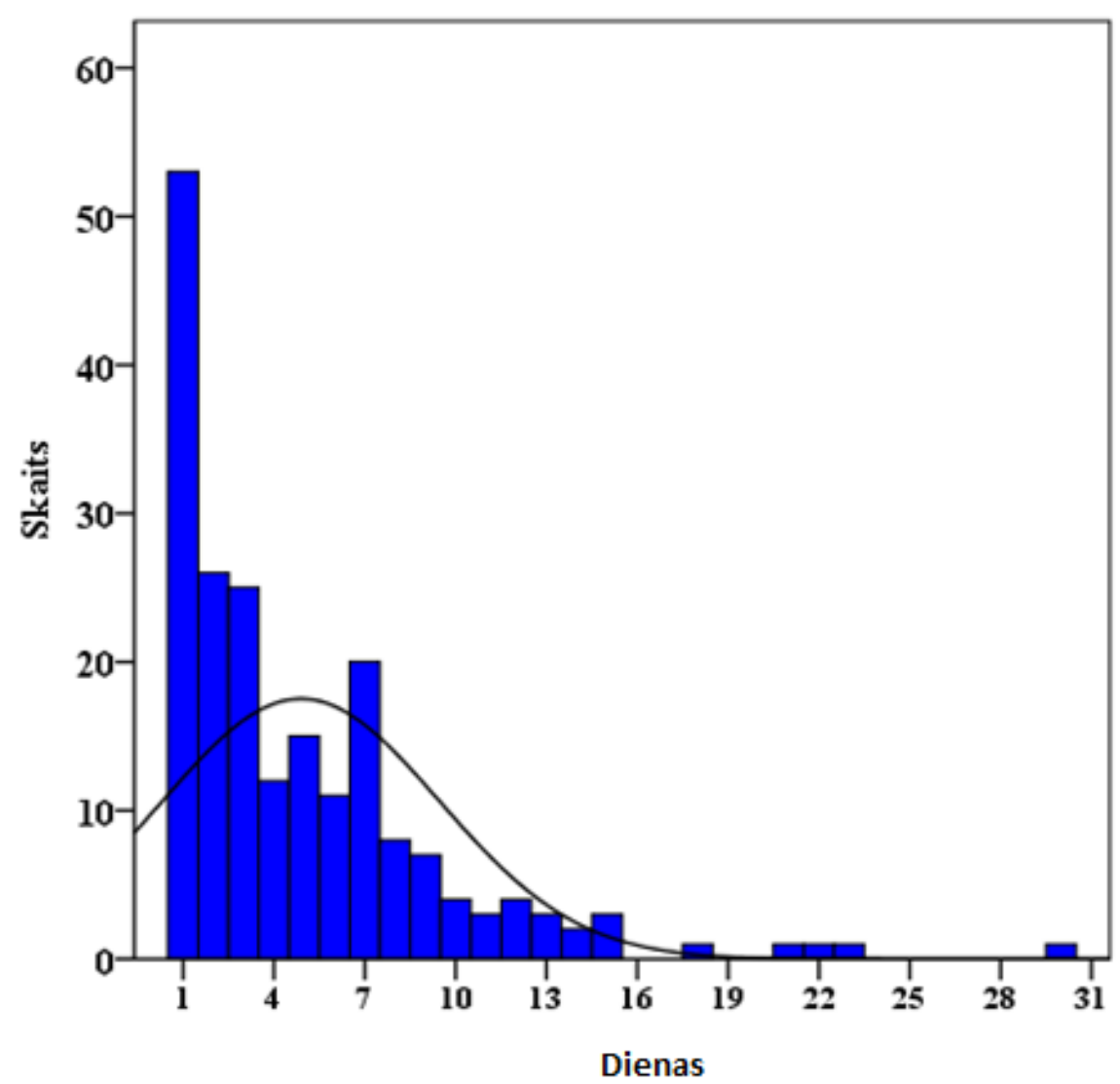

5.4. att. Pleiras dobuma punkcijas veikšanas diena 
Apkopojot dokumentēto pleiras punktāta laboratoro izmeklēšanu, visbiežāk - 130 gadījumos (47,8 \% pacientu, kuriem veikta punkcija) - bija noteikta klīniskā analīze, LDH, olbaltumvielas un citolog̣ija. 29 gadījumos (10,7\% pacientu, kuriem veikta punkcija) nebija veiktas nekādas pleiras punktāta analīzes (5.5. attēls, 5.3. tabula).

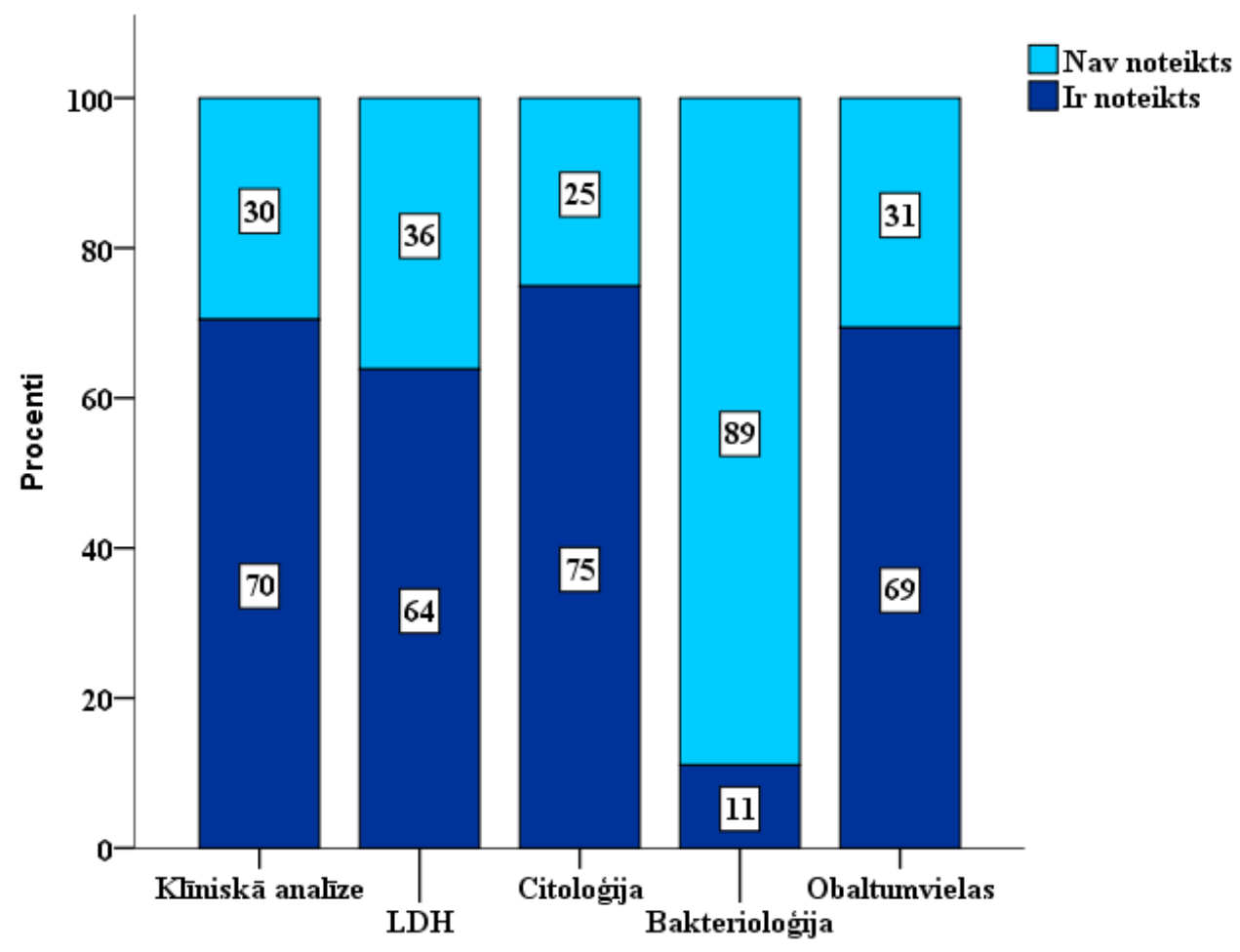

5.5. att. Procentuālais veikto un neveikto laboratoro pleiras punktāta analǐžu sadalījums 
Stacionāra medicīniskajās kartēs fiksētās pleiras punktāta laboratorās izmeklēšanas metodes

\begin{tabular}{|c|c|c|}
\hline \multirow[b]{2}{*}{ Izmeklēšanas veids } & \multicolumn{2}{|r|}{ Frekvence } \\
\hline & Skaits & $\begin{array}{c}\text { \% no kopējāa } \\
\text { punktēto pacientu } \\
\text { skaita }\end{array}$ \\
\hline Klīniskā analīze, LDH, olbaltumvielas, citolog̣ija & 130 & 47,7 \\
\hline Tikai citologija & 26 & 9,6 \\
\hline Klīniskā analīze, olbaltumvielas, citologija & 24 & 8,8 \\
\hline Klīniskā analīze, LDH, olbaltumvielas & 15 & 5,5 \\
\hline Tikai bakteriologija & 9 & 3,3 \\
\hline Klīniskā analīze, LDH, olbaltumvielas, citologiija, bakteriologiija & 7 & 2,6 \\
\hline Tikai LDH & 5 & 1,8 \\
\hline LDH, citologija & 5 & 1,8 \\
\hline Klīniskā analīze, LDH, citologiija & 4 & 1,5 \\
\hline LDH, bakteriologija & 3 & 1,1 \\
\hline Klīniskā analīze, LDH, olbaltumvielas, bakteriologija & 3 & 1,1 \\
\hline Klīniskā analīze, olbaltumvielas, citologiija, bakteriologija & 3 & 1,1 \\
\hline Klīniskā analīze, olbaltumvielas & 2 & 0,7 \\
\hline Klīniskā analīze, olbaltumvielas, bakteriologija & 2 & 0,7 \\
\hline Klīniskā analīze, citologija & 1 & 0,4 \\
\hline LDH, olbaltumvielas, citologija & 1 & 0,4 \\
\hline LDH, olbaltumvielas, citologija, bakteriologija & 1 & 0,4 \\
\hline Olbaltumvielas, citologija, bakteriologija & 1 & 0,4 \\
\hline Klīniskā analīze, citoloğija, bakterioloğija & 1 & 0,4 \\
\hline Nav veiktas analīzes & 29 & 10,7 \\
\hline Kopā & 272 & 100 \\
\hline
\end{tabular}

Izvērtējot noteiktās izrakstǐšanās diagnozes, 426 (59,5\%) pacientiem šķidrums pleiras dobumā tika traktēts kā kardiālas hidrotorakss, 103 (14,4\%) pacientiem MPE, 71 $(9,9 \%)$ - parapneimonisks pleirīts, $30(4,2 \%)$ pacientiem izrakstīšanās diagnozē bija minēta pleiras empiēma, $11(1,5 \%)$ - hemotorakss, $6(0,8 \%)$ - tuberkulozs pleirīts. Citas ǵenēzes šķidrums tika minēts 36 pacientiem (5\%): nefrotisks sindroms 9 gadījumos, aknu ciroze -6 , plaušu artērijas trombembolija - 7, hiperhidratācija hroniskas nieru mazspējas slimniekiem - 6, pēctraumatisks pleirīts - 2, Meigsa sindroms - 1, sistēmas sarkanā vilkēde -1 , jatrogēns hidropneimotorakss -1 , neskaidri formulēta diagnoze -3 gadījumos. 33 pacientiem $(4,6 \%)$ šķidruma veids izrakstīšanās diagnozē nebija precizēts (5.6. attēls). 


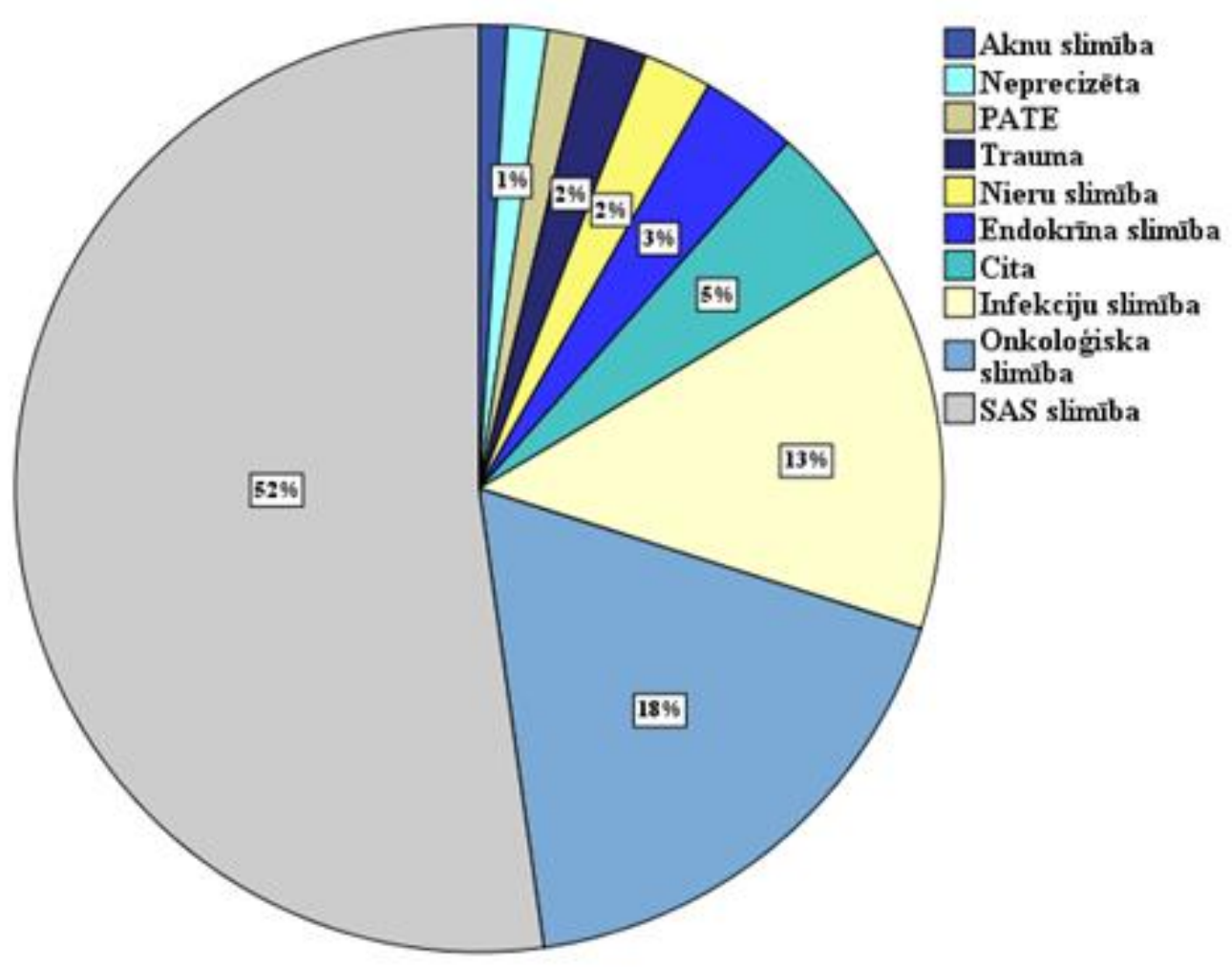

5.6.att. Pacientu $(n=716)$ procentuālais iedalījums pēc izrakstī̌anās diagnozes

Sīkāk analizējot izrakstīšanās diagnozes un pleiras punktāta izmeklējumus, konstatēts, ka 426 (59,5 \% no visiem) pacientiem izrakstīšanās diagnozē pleiras šķidrums tika saistīts ar sirds mazspēju, no tiem punkcija tika veikta 98 (23\% pacientu ar kardiālu hidrotoraksu). $51(11,9 \%)$ punktētam pacientam diagnoze apstiprināta arī laboratori - LDH līmenis punktātā liecina par transudātu, turpretim 13 (3,1\%) punktētajiem pacientiem LDH līmenis liecina par eksudātu. 34 (23\%) pacientiem laboratorie izmeklējumi bija nepietiekami, lai precizētu šķidruma raksturu un etiologiju.

$103(14,4 \%)$ no visiem pacientiem izrakstīšanās diagnozē minēts MPE, no tiem $62(60,2 \%)$ pacientiem veikta pleiras dobuma punkcija un tikai 37 (36\%) pacientiem diagnoze apstiprināta arī citologiski. 8 (7,8 \%) pacientiem bija noteikts LDH līmenis, 5 (4,9\%) no tiem tas atbilda transudātam. $17(16,5 \%)$ pacientiem laboratoriskie izmeklējumi nav bijuši pietiekami, lai noteiktu šķidruma raksturu un etiolog̣iju.

$71(9,9 \%)$ no visiem pacientam izrakstīšanās diagnozē minēts parapneimonisks pleirīts, no tiem $37(52,1 \%)$ pacientiem veikta pleiras dobuma punkcija. $23(32,3 \%)$ pacientiem apstiprināts eksudāts, 7 (9,9\%) pacientiem LDH līmenis liecina par transudātu un 7 (9,9\%) nav bijuši pietiekami laboratorie izmeklējumi šķidruma rakstura un etiolog̣ijas precizēšanai. 
Atsevišķi izdalīta pacientu grupa (30 pacienti - 4,2 \%), kam izrakstīšanās diagnozē minēta pleiras empiēma. No šīs grupas $12(40 \%)$ pacientiem empiēma konstatēta bakteriologíiski, $15(50 \%)$ pacientiem bijis eksudāts un 2 gadījumos laboratoriskā izmeklēšana bijusi nepiln̄iga.

$33(4,6 \%)$ gadījumos diagnozē nebija precizēts šķidruma veids, 16 no tiem (48,5\%) pacientiem bija veikta pleiras dobuma punkcija.

\subsection{Prospektīvi iegūto datu analīze}

\subsubsection{Pacientu raksturojums}

No 2011. gada 8. augusta līdz 2014. gada 13. jūnijam SIA RAKUS stacionāra “Gaiļezers” Iekšḳ̄ịo slimību klīnikas Pulmonologijas nodaḷā secīgi tika stacionēti 144 pacienti, kuriem rentgenologiiski un ultrasonsokospiski tika konstatēts šķidrums pleiras dobumā, kuriem bija nepieciešama pleiras dobuma punkcija diagnostiskos un terapeitiskos nolūkos un kuri parakstīja piekrišanu pētījumam un pleiras dobuma punkcijai. 69 (47,9 \%) no tiem bija vīrieši. Pacientu vecums bija no 22 līdz 97 gadiem (5.6. attēls). 136 (94,4 \%) pacienti no stacionārā izrakstīti, bet 8 - miruši $(5,5 \%)$.

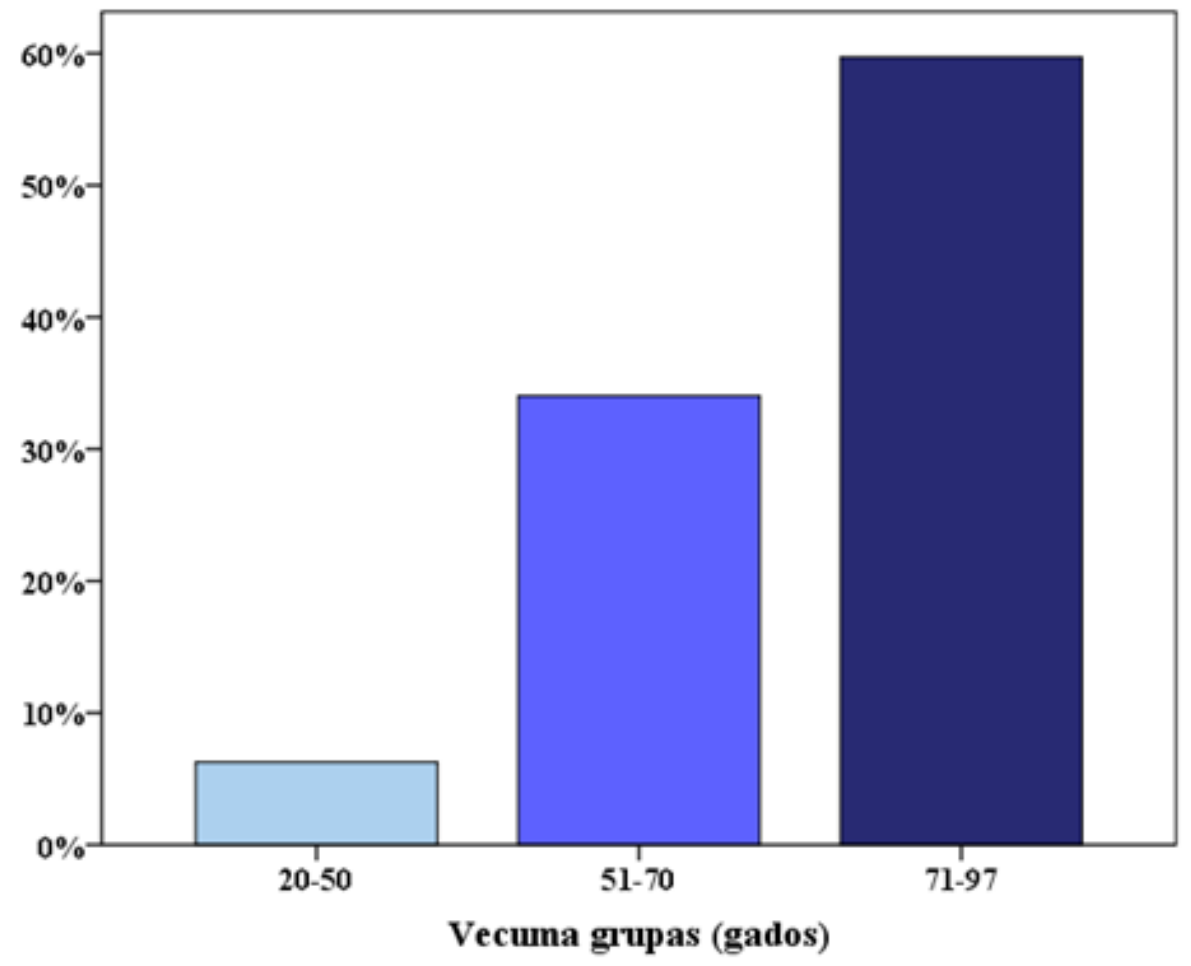

5.6. att. Pacientu $(n=144)$ iedalījums pēc vecuma 


\subsubsection{Pleiras šḳidruma etioloǵijas raksturojums}

Tika konstatēts, ka apsekotos pacientus pēc pleiras šķidruma etiologijas var iedalìt: kardiālā hidrotoraksa grupā - $42(29,2 \%), 22(52,3 \%)$ no tiem vīrieši; pacienti; MPE grupā-67 (46,5\%) pacienti, $21(31,3 \%)$ no tiem vīrietis; parapneimoniska pleirīta grupā - $27(18,8 \%)$ pacienti, $19(70,3 \%)$ no tiem vīrieši. $6(4,1 \%)$ pacientiem konstatēja tuberkulozu pleirītu, $1(0,7 \%)$ pacientam pankreatogēnu pleirītu un $1(0,7 \%)$ pacientam PATE ar pleirìtu (5.7. attēls). N̦emot vērā mazo tuberkuloza pleirìta, pankreatogēna pleirìta un PATE pacientu skaitu, šie pacienti tālāk analizēti netika.

MPE grupā $24(35,8 \%)$ pacientiem bija plaušu vēzis, 14 (20,9\%) pacientēm - olnīcu vēzis, 13 (19,4\%) pacientēm - krūts vēzis, 2 pacientiem - nieru vēzis, 2 pacientēm - dzemdes kakla vēzis, 2 pacientiem - kungga vēzis, 1 pacientam - aizkungǵa dziedzera vēzis, 1 pacientei sarkoma, 1 pacientam - mezotelioma, 1 pacientam - melanoma, 1 pacientam - prostatas vēzis. 5 pacientiem primāro audzēja lokalizāciju noskaidrot nebija iespējams (5.8. attēls).

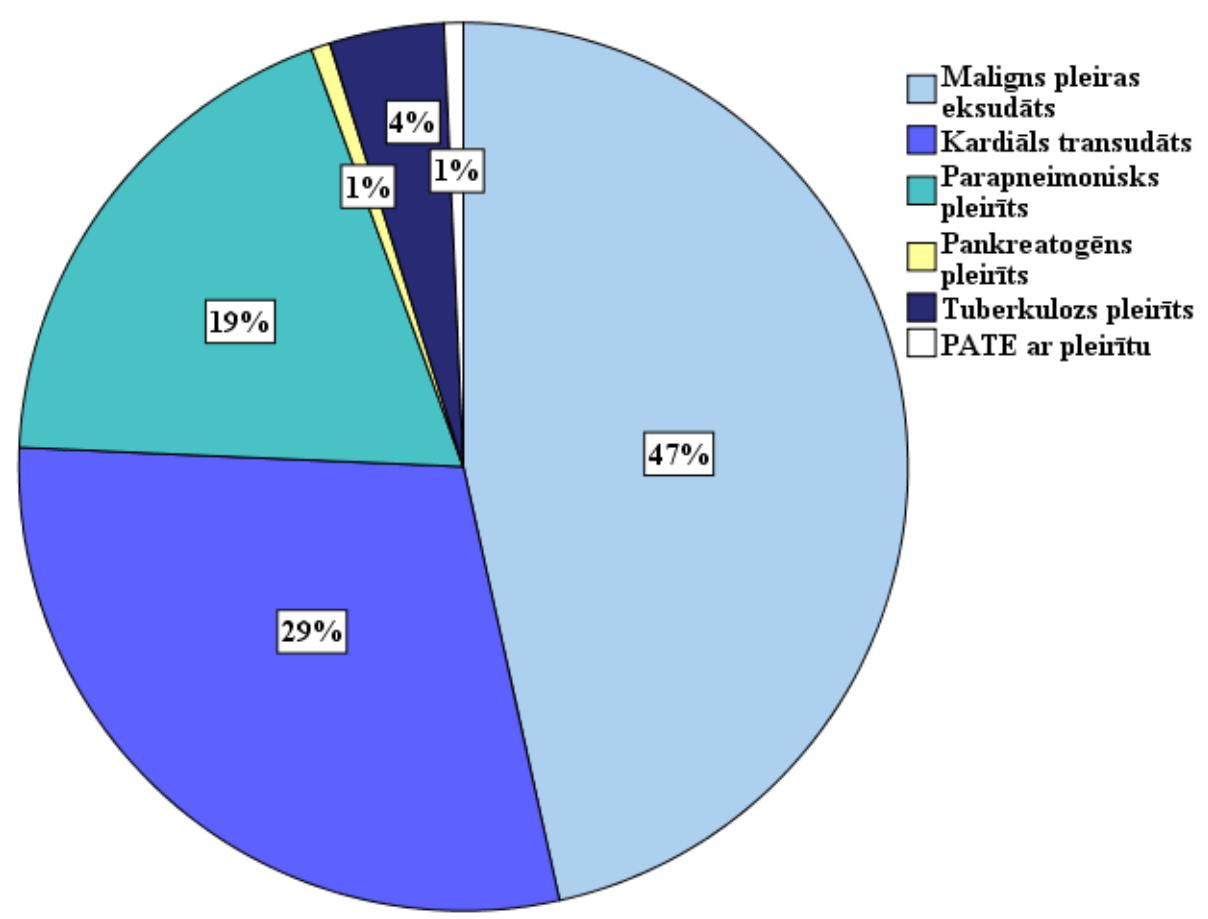

5.7. att. Pleiras šḳidruma etioloğija $(n=144)$ 


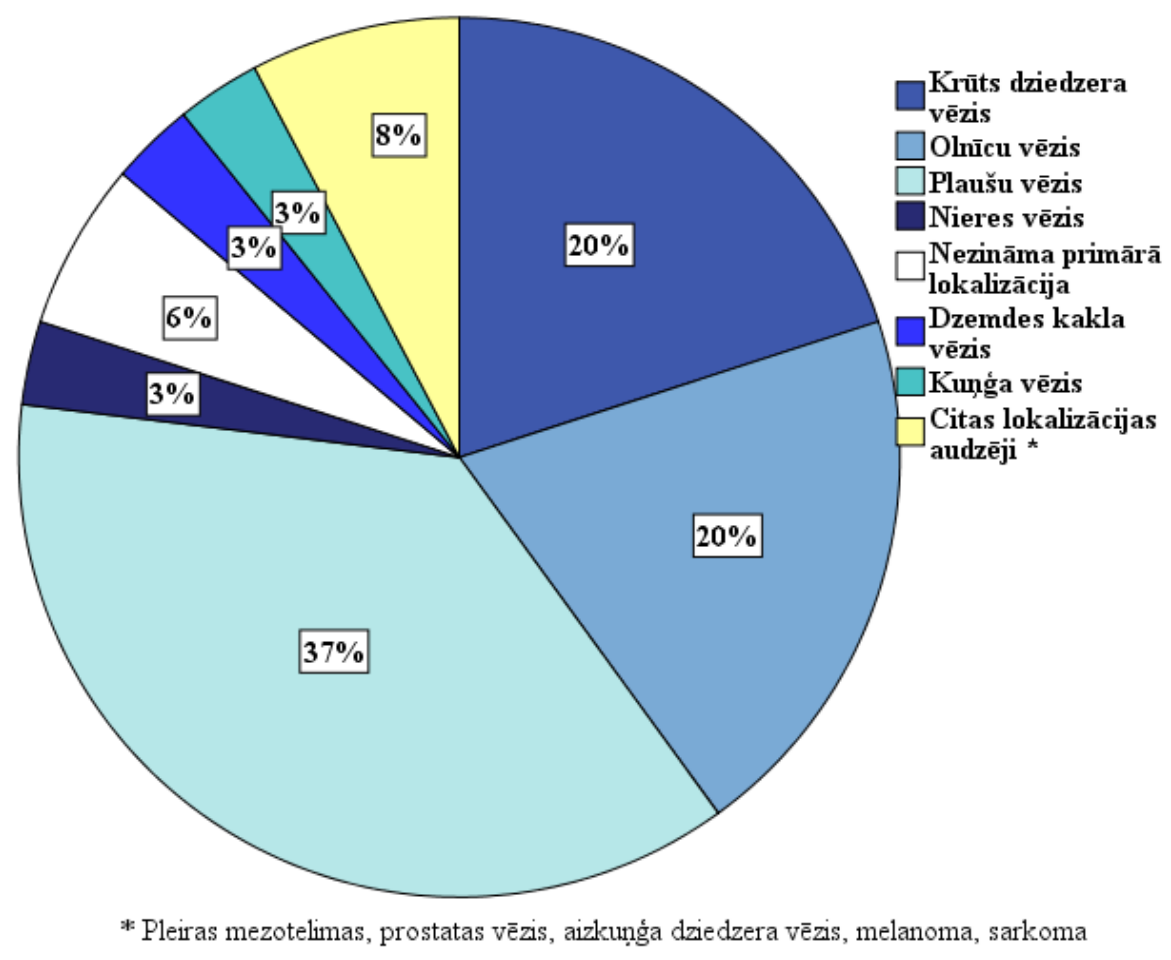

5.8. att. MPE sadalījums atkarībā no primārās audzēja lokalizācijas $(\mathbf{n}=67)$

\subsubsection{Laita kritēriji}

\section{Kardiāla hidrotoraksa grupa}

Kardiāla hidrotoraksa grupā tika iedalīti 42 (29,2\%) pacienti ar zināmu sirds slimību, vecumā no 50 līdz 92 gadiem, kuriemanamnēzē zināma sirds slimība un klīniski vērojamas hroniskas sirds mazspējas dekompensācijas pazīmes.

$34(81 \%)$ pacientiem Laita kritēriji atbilda transudātam, bet 8 (19\%) pacientiem Laita kritēriji atbilda eksudātam (2 pacientiem olbaltumvielas punktātā/olbaltumvielām serumā bija $>0,5 ; 3$ pacientiem LDH punktātā pret LDH serumā bija > 0,6, 1 pacientam LDH bija > 0,6 un LDH > 160 U/L (2/3 no LDH augšējās seruma normas); 3 pacientiem visi Laita kritēriji bija nedaudz paaugstināti. Visiem šiem pacientiem tika noteikts olbaltumvielu gradients. 7 pacientiem tas bija $>31 \mathrm{~g} / \mathrm{L}$, bet 1 pacientam tas bija $<31 \mathrm{~g} / \mathrm{L}$, bet BNP serumā šim pacientam bija 1631 pg/ml. Kardiālā hidrotoraksa grupā izrakstīti 39 (92,9\%) pacienti, bet miruši 3 (7,1\%) pacienti (2., 4. un 11. stacionēšanas dienā). 


\section{Parapneimoniski pleirīti}

Parapneimonisku pleirītu grupā tika iekḷauti 27(18,6\%) pacienti vecumā no 38 līdz 97 gadiem ar pneimonijas klīnisko ainu: akūta slimība ar klepu, febrilu temperatūru, paaugstinātiem iekaisuma rādītājiem (CRO līmenis) un atbilstošu rentgenologisko atradni. Visiem pacientiem bija pozitīvs vismaz viens Laita kritērijs. 20 (74\%) pacientiem bija pozitīvs pirmais Laita kritērijs, t.i., olbaltumvielu līmenis punktātā pret olbaltumvielu līmeni serumā > 0,5 (0,29-2,28), $26(96,3 \%)$ pacientiem bija pozitīvs 2. Laita kritērijs - LDH līmenis punktātā pret LDH līmeni serumā > 0,6 $(0,51-54,67)$ un 27 (100\%) pacientiem bija pozitīvs 3. Laita kritērijs - LDH līmenis punktātā > 2/3 no laboratorijas normas (168-1006 U/L). Visiem pacientiem pleiras dobuma šķidrums izmeklēts mikrobiologiski, bet tikai diviem $(7,4 \%)$ identificēta mikroflora: vienam pacientam Klebsiella pneumoniae, vienam pacientam - Staphylococcus sacchrolyticus. 3 pacientiem bija nepieciešama pleiras dobuma drenāža ar fibrinolītisko enzīmu ievadīšanu. Izrakstīti 26 (96,3\%) pacienti, bet miris 1 (3,7\%) pacients 9. stacionēšanas dienā.

\section{Maligni pleiras eksudāti}

MPE grupā tika iekḷauti 67 (46,5\%) pacienti vecumā no 40 līdz 90 gadiem. Laita kritēriji bija negatīvi 2 pacientiem (2,9\%). 59 (88\%) pacientiem bija pozitīvs 1. Laita kritērijs - olbaltmvielus līmenis serumā pret olbaltumvielu līmeni punktātā $(0,510-4,25) ; 50$ (74,6\%) pacientiem bija pozitīvs 2. Laita kritērijs - LDH punktātā pret LDH serumā > 0,6 $(0,64-9,78)$ un 52 pacientiem $(77,6 \%)$ bija pozitīvs 3. Laita kritērijs - LDH līmenis punktātā > 2/3 no augšējās laboratorijas normas (163-1908 U/L). Visiem pacientiem pleiras punktāts tika izmeklēts citologiski, $45(67,2 \%)$ pacientiem tika atrastas malignas šūnas. 18 (26,9\%) pacientiem tika veikta talka pleirodēze. $63(94 \%)$ pacienti tika izrakstīti, bet $4(6 \%)$ pacienti nomira, (3., 9., 14. un 22. dienā), t.sk., 1 pacients nomira pēc talka pleirodēzes.

\section{Tuberkulozi pleirīti}

Tuberkulozi pleirīti tika diagnosticēti 6 pacientiem (22-79 gadi), t. sk. 5 vīriešiem. Visiem pacientiem monomorfo nukleāro šūnu skaits pleiras punktātā bija 90-98 \%. Pieciem pacientiem pleiras tuberkuloze tika pierādīta ar slēgtās pleiras biopsijas histoloǵisko izmeklēšanu, savukārt vienam pacientam pleiras punktātā tika atrastas Mycobacterium tuberculosis DNS. 
Pankreatogēns pleiras eksudāts tika konstatēts vienam 57 gadus vecam vīrietim, konstatējot paaugstinātu lipāzi pleiras punktātā (3355 U/L).

PATE pleirīts konstatēts vienam 83 gadus vecam vīrietim (eksudāts), PATE pierādīta datortomogrāfija angiogrāfijā.

\subsubsection{Leikocītu sastāvs}

Nosakot procentuālo monomorfo nukleāro $(\mathrm{MMN})$ un polimorfo nukleāro (PMN) leikocītu procentuālo daudzumu, tika konstatēts, ka MPE mediānais PMN daudzums bija $35 \%$ (10 \%; $61 \%)$, bet MMN - $63 \%$ (33\%; $89 \%)$. Transudātos PMN mediāna bija $22 \%$ (12 \%; 60), MMN - $78 \%$ (39\%; $88 \%$ ), bet parapneimoniskos pleirītos - PMN mediāna bija $70 \%$ (39 \%; $87 \%)$ un MMN - $30 \%(10 \% ; 51 \%)$. Gan pēc PMN, gan MMN procentuālā sastāva tikai parapneimonisks pleirīts ticami atškīīās no transudāta un MPE ( $p<0,001)$, bet MPE un transudāti savstarpēji statistiski ticami neatšḳiras.

Analizējot ROC līkni, pēc pētījuma datiem, MMN un PMN šūnu procentuālais sastāvs nav precīzs diagnostisks rīks dažādas etioloǵijas pleiras škidrumu diferenciāldiagnostikā - 5.9. attēls un 5.4. tabula.

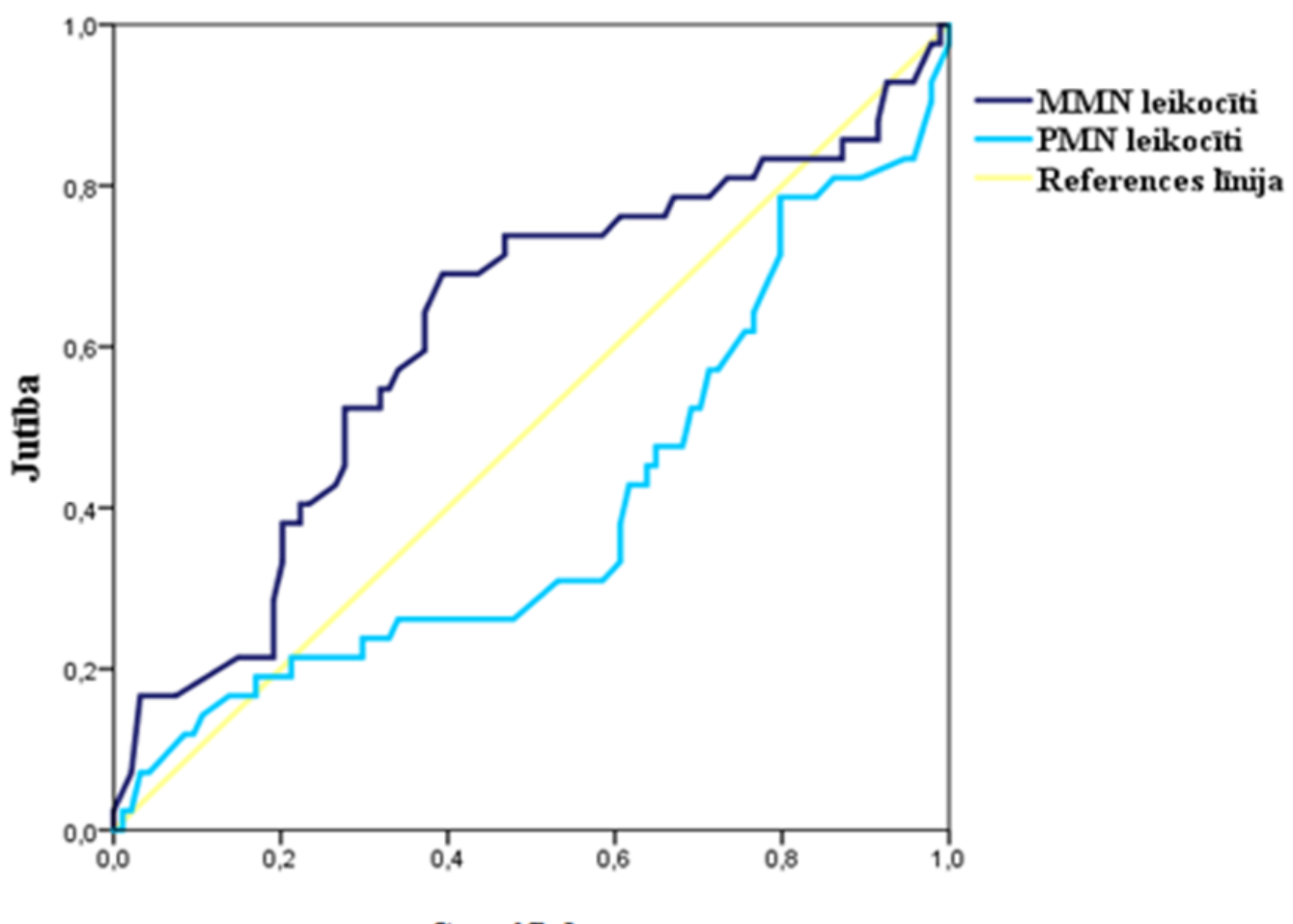

Specifiskums

5.9. att. ROC līkne un zemlīknes laukums (Area under the curve) PMN un MMN šūnām 
Zemlīknes laukums (Area under the curve) PMN un MMN šūnu procentuālam sastāvam

\begin{tabular}{|l|l|l|l|l|l|}
\hline \multicolumn{1}{|c|}{ Rādītājs } & \multirow{2}{*}{$\begin{array}{c}\text { Zemlīknes } \\
\text { laukums }\end{array}$} & \multirow{2}{*}{ SE } & \multirow{2}{*}{$\begin{array}{c}\text { Būtiskuma } \\
\text { līmenis }\end{array}$} & \multicolumn{2}{|c|}{ 95\% TI } \\
\cline { 5 - 6 } & & & & Apaǩšejjā & Augšējā \\
\hline MMN & 0,618 & 0,055 & $<0,028$ & 0,511 & 0,725 \\
\hline PMN & 0,401 & 0,055 & $<0,065$ & 0,293 & 0,509 \\
\hline
\end{tabular}

SE - standartkḷūda; 95\% T.I. - ticamības intervāls 95\% robežās

PMN/MMN mediānā attiecība MPE grupā bija 1,7 (0,61; 8,09), transudātu grupā - 3,55 $(0,65 ; 7,53)$, bet parapneimonisku pleirìtu grupā - 0,43 $(0,11 ; 1,37)$. MPE MMN un PMN šūnu attiecība statistiski ticami neatšḳ̄iās no transudātiem un parapneimoniskiem pleirītiem (attiecīgi $\mathrm{p}=0,170$ un 0,078), bet statistiski nozīmīga attiecības atškirība bija starp transudātu un parapneimonisku pleirītu $(\mathrm{p}=0,004)$.

\subsubsection{Citoloğiskā izmeklēšana}

Malignas šūnas pleiras punktātā atrada $44(65,7 \%)$ no 67 pacientiem ar MPE. 38 pacientiem $(83,4 \%)$ malignas šūnas atrada pirmajā, bet $6(13,6 \%)$ - otrajā pleiras punktāta citologiiskās izmeklēšanas reizē.

Pozitīva citologiija bija 3 nezināmas primāras lokalizācijas audzējiem, 8 pacientēm ar krūts vēzi, 11 pacientēm ar olnīcu vēzi, 14 pacientiem ar plaušu vēzi, 2 pacientiem ar nieres vēzi, 2 pacientēm ar dzemdes kakla vēzi, 1 pacientam ar aizkuṇǵa dziedzera vēzi, 2 pacientiem ar nieres vēzi un 1 pacientam ar melanomu. Malignas šunas pleiras punktātā neatrada 2 pacientiem ar nezināmas lokalizācijas diseminētu vēzi, 5 pacientēm ar krūts vēzi, 3 pacientēm ar olnīcu vēzi, 10 pacientiem ar plaušu vēzi, 1 pacientam ar mezoteliomu, 1 pacientam ar sarkomu, un vienam pacientam ar prostatas vēzi.

\subsubsection{Bakterioloğiskā analīze}

27 pacientiem pleiras punktāts tika nosūtīts mikrobioloǵiskai izmeklēšanai, bet tikai 2 pacientiem uzsējums bija pozitīvs - vienā gadījumā tika identificēta Klebsiella pneumoniae, bet vienā - Staphylococcus saphrolyticus. 


\subsubsection{Audzēju marḳieri}

\section{CA 125 un CEA}

Lai noskaidrotu, vai eksistē statistiski ticamas CA 125 un CEA atšķirības dažādas etiologijas pleiras šķidrumā, tālāk tika analizētas parapneimonisko pleirītu, malignu pleiras eksudātu un transudātu grupas un noteiktas šo audzēju markiieru mediānās vērtības un 25. un 75. percentile serumā un punktātā, kā arī punktāta/seruma attiecība (5.5. tabula). Tuberkulozie pleirīti un pankreatogēns pleirīts un eksudāts PATE gadījumā tālākā analīzē netika iekḷauts sakarā ar mazo pacientu skaitu. Redzams, ka CA 125 vērtības MPE pacientiem gan pleiras punktātā, gan serumā statistiski ticami atšķiras no transudāta un parapneimoniska pleirīta pacientiem, bet punktāta/seruma attiecība statistiski ticami atšķir MPE no transudāta. Savukārt CEA vērtības statististiski ticami starp MPE, transudāta un parapneimoniska pleirīta grupām atškiiras tikai pleiras punktātā. Kardiāla hidrotoraksa CA 125 līmenis būtiski neatšḳīrās no līmeņa parapneimonisko pleirītu grupā ne punktātā $(p=0,850)$, ne arī serumā $(p=0,694)$.

5.5. tabula

Mediānais Ca-125 un CEA serumā un pleiras šḳidrumā pacientiem ar transudātu, malignu eksudātu un parapneimonisku pleirītu

\begin{tabular}{|c|c|c|c|c|c|c|}
\hline \multirow[b]{2}{*}{$\begin{array}{l}\text { Mar- } \\
\text { ķieris }\end{array}$} & \multirow[b]{2}{*}{ Substrāts } & \multicolumn{3}{|c|}{ Mediāna (25. un 75. percentile) } & \multirow[b]{2}{*}{$\begin{array}{c}\text { Būtiskuma } \\
\text { līmenis, } \\
\text { p1 }\end{array}$} & \multirow[b]{2}{*}{$\begin{array}{c}\text { Būtiskuma } \\
\text { līmenis, } \\
\text { p2 }\end{array}$} \\
\hline & & Transudāts & $\begin{array}{c}\text { Parapnei- } \\
\text { monisks } \\
\text { pleirīts }\end{array}$ & MPE & & \\
\hline \multirow{3}{*}{$\frac{\mathfrak{c}}{\mathbb{U}}$} & $\begin{array}{l}\text { Pleiras } \\
\text { punktāts U/ml }\end{array}$ & $\begin{array}{c}686 \\
(379-1029) \\
\end{array}$ & $\begin{array}{c}412 \\
(245-695)\end{array}$ & $\begin{array}{c}1644 \\
(813-2982) \\
\end{array}$ & 0,001 & 0,002 \\
\hline & Serums, U/ml & $\begin{array}{c}182,0 \\
(89-316)\end{array}$ & $\begin{array}{c}62 \\
(41-164) \\
\end{array}$ & $\begin{array}{c}267 \\
(107-597)\end{array}$ & 0,013 & 0,010 \\
\hline & $\begin{array}{l}\text { Punktāts/ } \\
\text { serums }\end{array}$ & $\begin{array}{c}3,64 \\
(2,45-5,75)\end{array}$ & $\begin{array}{c}5,5 \\
(3,0-11,0)\end{array}$ & $\begin{array}{c}5,53 \\
(3,82- \\
10,61) \\
\end{array}$ & 0,001 & 0,216 \\
\hline \multirow{3}{*}{ 皖 } & $\begin{array}{l}\text { Pleiras } \\
\text { punktāts ng/ml }\end{array}$ & $\begin{array}{c}0,75(0,51- \\
1,60) \\
\end{array}$ & $\begin{array}{c}1,91 \\
(1,09-3,63) \\
\end{array}$ & $\begin{array}{c}6,23 \\
(0,92-57,3) \\
\end{array}$ & 0,005 & 0,020 \\
\hline & Serums, ng/ml & $\begin{array}{c}2,34 \\
(1,40-3,67)\end{array}$ & $\begin{array}{c}2,57 \\
(1,40-4,48)\end{array}$ & $\begin{array}{c}3,07 \\
(1,30- \\
12,79)\end{array}$ & 0,218 & 0,284 \\
\hline & $\begin{array}{l}\text { Punktāts/ } \\
\text { serums }\end{array}$ & $\begin{array}{c}0,38 \\
(0,26-0,66) \\
\end{array}$ & $\begin{array}{c}0,70 \\
(0,37-1,48)\end{array}$ & $\begin{array}{c}1,23 \\
(0,65-4,78)\end{array}$ & 0,061 & 0,116 \\
\hline
\end{tabular}

p1 - statistiskā ticamība transudāts vs MPE

p2 - statistiskā ticamība parapneimonisks pleirīts vs MPE

Lai spriestu par audzēju marķieru klīnisko nozīmi, tika aprēḳināta jutība un specifiskums gan marķieru līmeņiem serumā un punktātā, gan arī to punktāta/seruma attiecībai.

5.6. tabulā redzams, ka gandrīz visos gadījumos visaugstākais specifiskums ir ar robežvērtību 75. percentilē, bet jutība - 25. percentilē. 
CA 125 un CEA jutība un specifiskums dažādām robežvērtībām MPE

\begin{tabular}{|c|c|c|c|c|}
\hline Marķieris & Substrāts & Robežvērtība* & Jutība (\%) & Specifiskums (\%) \\
\hline \multirow{9}{*}{ CA 125} & \multirow{3}{*}{ Punktāts U/ml } & $\geq 813$ & 79,1 & 70,1 \\
\hline & & $\geq 1644$ & 53,7 & 96,1 \\
\hline & & $\geq 2982$ & 28,4 & 98,7 \\
\hline & \multirow{3}{*}{ Serums U/ml } & $\geq 108$ & 76,2 & 69,3 \\
\hline & & $\geq 268$ & 50,8 & 77,9 \\
\hline & & $\geq 597$ & 25,4 & 98,7 \\
\hline & \multirow{3}{*}{ Punktāts/serums } & $\geq 3,82$ & 76,1 & 49,4 \\
\hline & & $\geq 5,53$ & 50,8 & 66,2 \\
\hline & & $\geq 10,61$ & 25,4 & 87,0 \\
\hline \multirow{9}{*}{ CEA } & \multirow{3}{*}{ Punktāts ng/ml } & $\geq 0,92$ & 76,1 & 44,1 \\
\hline & & $\geq 6,23$ & 50,7 & 94,8 \\
\hline & & $\geq 57,3$ & 25,4 & 98,7 \\
\hline & \multirow{3}{*}{ Serums ng/ml } & $\geq 1.30$ & 76,1 & 18,2 \\
\hline & & $\geq 3,07$ & 50,8 & 66,2 \\
\hline & & $\geq 12,8$ & 25,4 & 96,1 \\
\hline & \multirow{3}{*}{ Punktāts/serums } & $\geq 0.60$ & 82,0 & 61,0 \\
\hline & & $\geq 1,23$ & 50,6 & 81,8 \\
\hline & & $\geq 4,78$ & 25,4 & 97,4 \\
\hline
\end{tabular}

*Mediāna, 25. un 75. percentiles

ROC līknes analīze parādīja, ka zemlīknes laukums (area under the curve) visaugstākais ir CA 125 līmenim pleiras punktātā - 0,751; 0,706 - serumā un 0,606 attiecībai punktātā/serumā, kas norāda uz CA 125 visaugstāko diagnostisko jutību punktātāsk. 5.10. attēlu un 5.7. tabulu. 


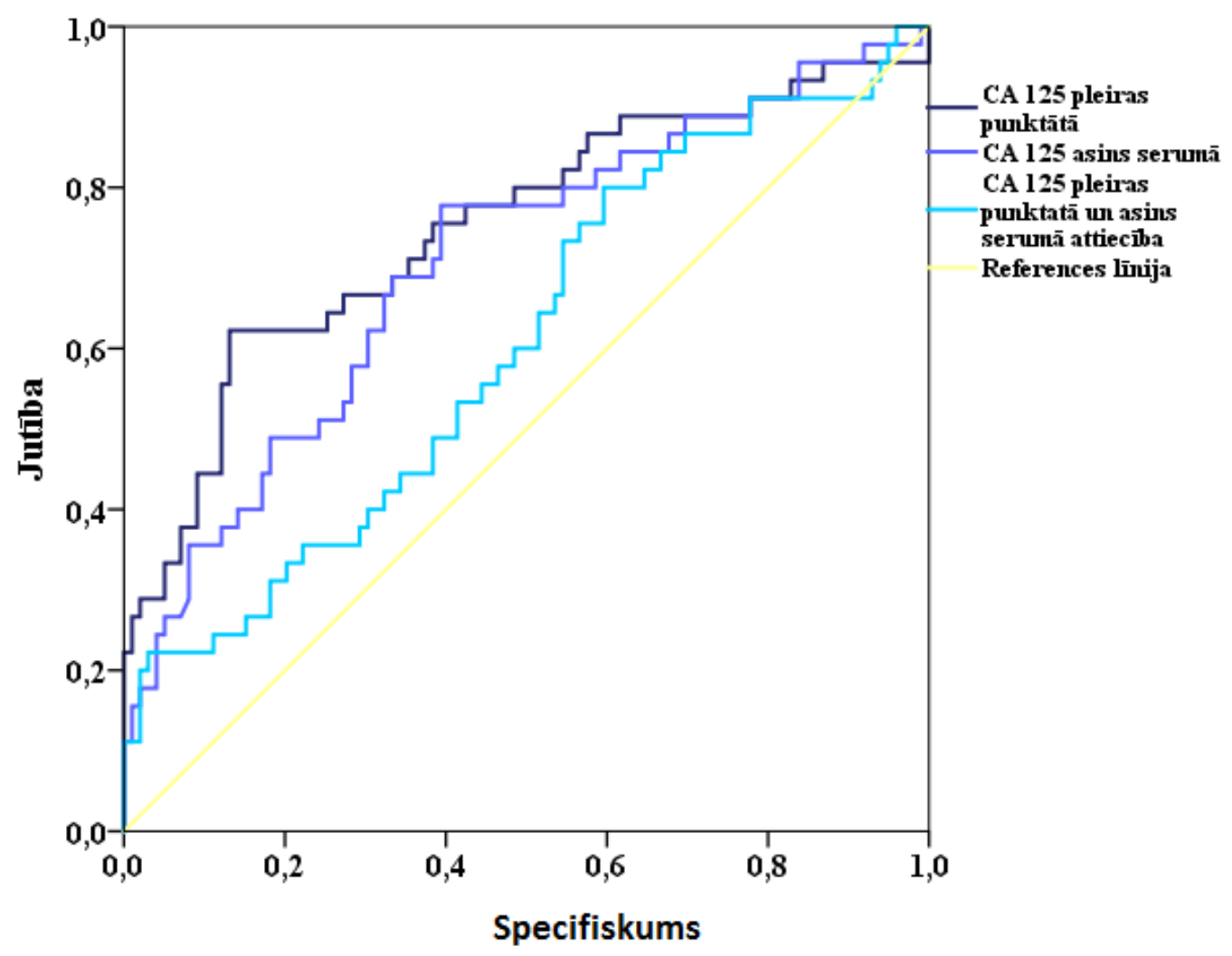

5.10. att. CA 125 ROC līkne un zemlīknes laukums (Area under the curve)

5.7. tabula

Zemlīknes laukuma (Area under the curve) aprēḳins audzēja marḳierim CA 125

\begin{tabular}{|l|c|c|l|l|l|}
\hline \multirow{2}{*}{ Rādītājs } & \multirow{2}{*}{$\begin{array}{c}\text { Zemlīknes } \\
\text { laukums }\end{array}$} & \multirow{2}{*}{ SE } & \multirow{2}{*}{$\begin{array}{c}\text { Būtiskuma } \\
\text { līmenis }\end{array}$} & \multicolumn{2}{c|}{ 95\% TI } \\
\cline { 5 - 6 } & & & Apakšējā & Augšējā \\
\hline CA 125 pleiras punktātā & 0,751 & 0,048 & $<0,001$ & 0,658 & 0,844 \\
\hline CA 125 serumā & 0,706 & 0,048 & $<0,001$ & 0,612 & 0,801 \\
\hline CA125 punktāts/serums & 0,606 & 0,051 & $=0,041$ & 0,506 & 0,707 \\
\hline
\end{tabular}

SE - standartkḷūda; 95\% T.I. - ticamības intervāls 95\% robežās

Audzēja marķiera CEA ROC līknes analīze parādīja, ka zemlīknes laukums marḳiera līmenim pleiras punktātā ir 0,720, serumā - 0,575 un attiecībai punktātā/serumā - 0,715, kas arī norāda uz CEA visaugstāko diagnostisko jutību punktātā, bet atškirīīā no CA 125 diagnostiski jutīgs tests ir šì marḳiera attiecība punktātā/serumā, savukārt CEA līmenis serumā nav statistiski ticami jutīgs diagnostisks tests - sk. 5.11. attēlu un 5.8. tabulu. 


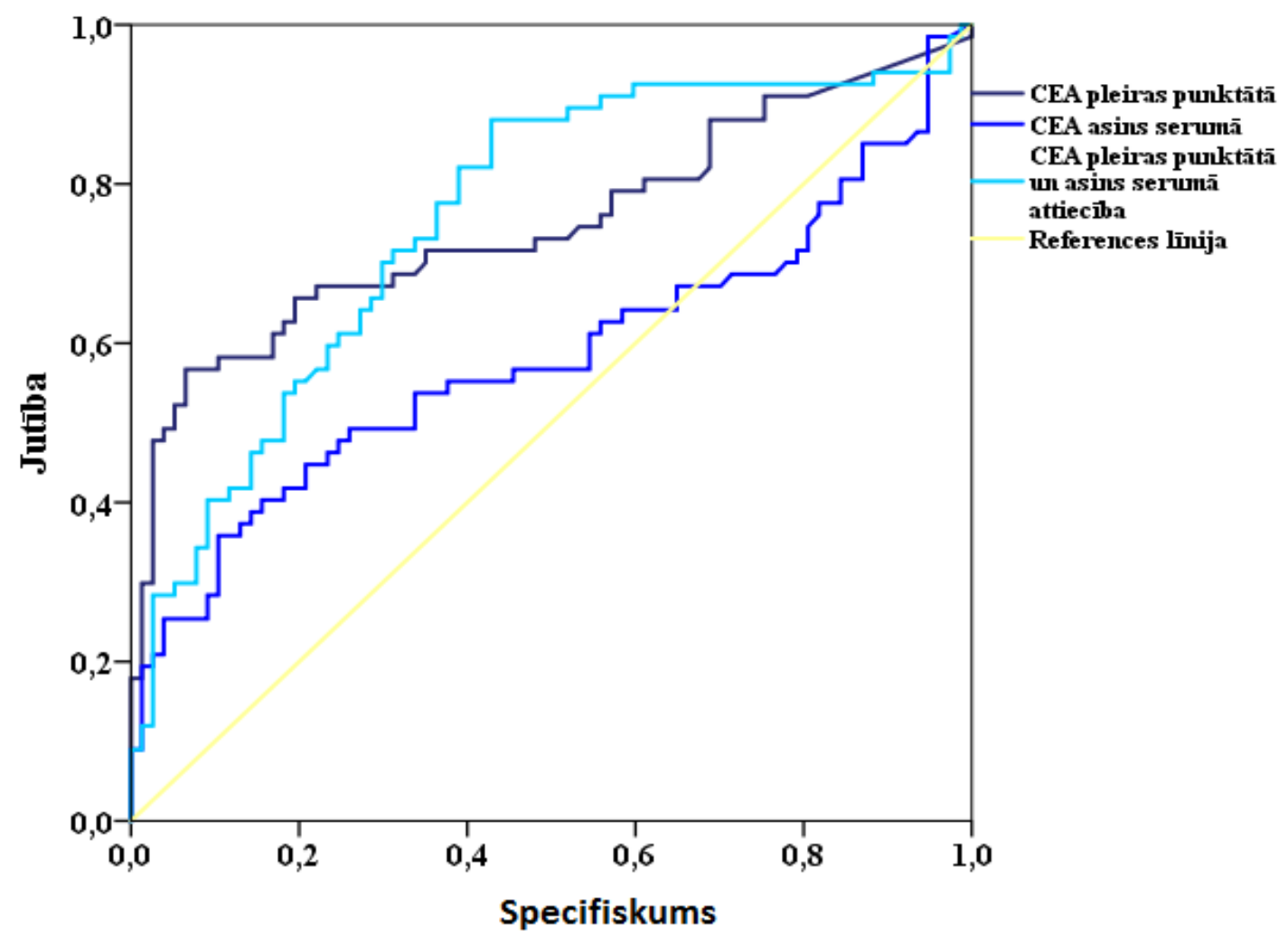

5.11. att. CEA ROC līkne un zemlīknes laukums (Area under the curve)

5.8. tabula

Zemlīknes laukuma (Area under the curve) aprēḳins audzēja marḳierim CEA

\begin{tabular}{|l|l|l|l|l|l|}
\hline \multirow{2}{*}{\multicolumn{1}{c|}{ Rādītājs }} & \multirow{2}{*}{$\begin{array}{c}\text { Zemlīknes } \\
\text { laukums }\end{array}$} & \multirow{2}{*}{ SE } & \multirow{2}{*}{$\begin{array}{c}\text { Būtiskuma } \\
\text { līmenis }\end{array}$} & \multicolumn{2}{c|}{ 95\% TI } \\
\cline { 5 - 6 } & & & Apakšējāa & Augšējāa \\
\hline CEA pleiras punktātāa & 0,720 & 0,050 & $<0,001$ & 0,621 & 0,819 \\
\hline CEA serumā & 0,575 & 0,056 & $=0,152$ & 0,465 & 0,684 \\
\hline CEA punktāts/serums & 0,715 & 0,49 & $<0,001$ & 0,618 & 0,811 \\
\hline
\end{tabular}

SE - standartkḷūda; 95\% T.I. - ticamības intervāls 95\% robežās

Ne CEA līmenis pleiras punktātā, serumā un pleiras / punktāta attiecība, nedz arī CA 125 līmenis pleiras punktātā, serumā un pleiras punktāta / seruma attiecība statistiski ticami neatšķīīās MPE ar pozitīvu un negatīvu citoloǵiju - visos gadījumos p >0,05.

Apvienojot abu markiieru labākos rādītājus ar augstāko jutību un specifiskumu (CA 125 $\geq 813 \mathrm{U} / \mathrm{ml}$ un CEA punktāta/seruma attiecība $\geq 0,6$, ieguvām juību 56,4 \% un specifiskumu $93,3 \%$. 


\subsubsection{BNP}

Kā papildus marķieris kardiālu hidrotoraksu diferencēšanai no MPE, tika analizēts BNP serumā un pleiras doumā. BNP mediānās vērtības un 25. un 27. percentile serumā un pleiras punktātā redzamas 5.9. tabulā. BNP līmenis statistiski ticami atšḳir transudātu no MPE un parapneimoniska pleirīta, bet nediferencē parapneimonisku pleirītu un MPE savā starpā.

5.9. tabula

BNP mediānās vērtības pleiras punktātā un serumā pacientiem ar transudātu, parapneimonisku pleirītu un MPE

\begin{tabular}{|c|c|c|c|c|c|c|c|}
\hline \multirow[b]{2}{*}{$\begin{array}{l}\text { Mar- } \\
\text { ķieris }\end{array}$} & \multirow[b]{2}{*}{ Sustrāts } & \multicolumn{3}{|c|}{ Mediāna (25.-27. percentile) } & \multirow{2}{*}{ 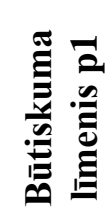 } & \multirow{2}{*}{ 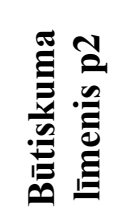 } & \multirow{2}{*}{ 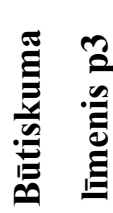 } \\
\hline & & Transudāts & $\begin{array}{c}\text { Para- } \\
\text { pneimonisks } \\
\text { pleirīts }\end{array}$ & MPE & & & \\
\hline \multirow{2}{*}{$\begin{array}{l}\text { BNP } \\
\mathrm{pg} / \mathrm{ml}\end{array}$} & $\begin{array}{l}\text { Pleiras } \\
\text { punktāts }\end{array}$ & $\begin{array}{c}1097 \\
(494-1582) \\
\end{array}$ & $\begin{array}{c}129 \\
(53-295) \\
\end{array}$ & $\begin{array}{c}97 \\
(61-159) \\
\end{array}$ & 0,010 & 0,504 & 0,006 \\
\hline & Serums & $\begin{array}{c}1631 \\
(071-3386)\end{array}$ & $\begin{array}{c}124 \\
(59-289)\end{array}$ & $\begin{array}{c}109 \\
(46-170)\end{array}$ & 0,001 & 0,932 & 0,001 \\
\hline
\end{tabular}

p1 - statistiskā ticamība transudāts vs MPE

p2 - statistiskā ticamība parapneimonisks pleirīts vs MPE

p3 - statistiskā ticamība parapneimonisks pleirīts vs transudāts

BNP ROC līknes analīze parādīja, ka zemlīknes laukums (area under the curve) ir vienādi gan pleiras punktātā, gan serumā - attiecīgi 0,92 un 0,92 , kas norāda metodes vienādo un pietiekami augsto diagnostisko vērtỉbu neatkarīgi no tā, kādā vidē BNP tiek noteikts - sk. 5.12. attēlu un 5.10. tabulu. 


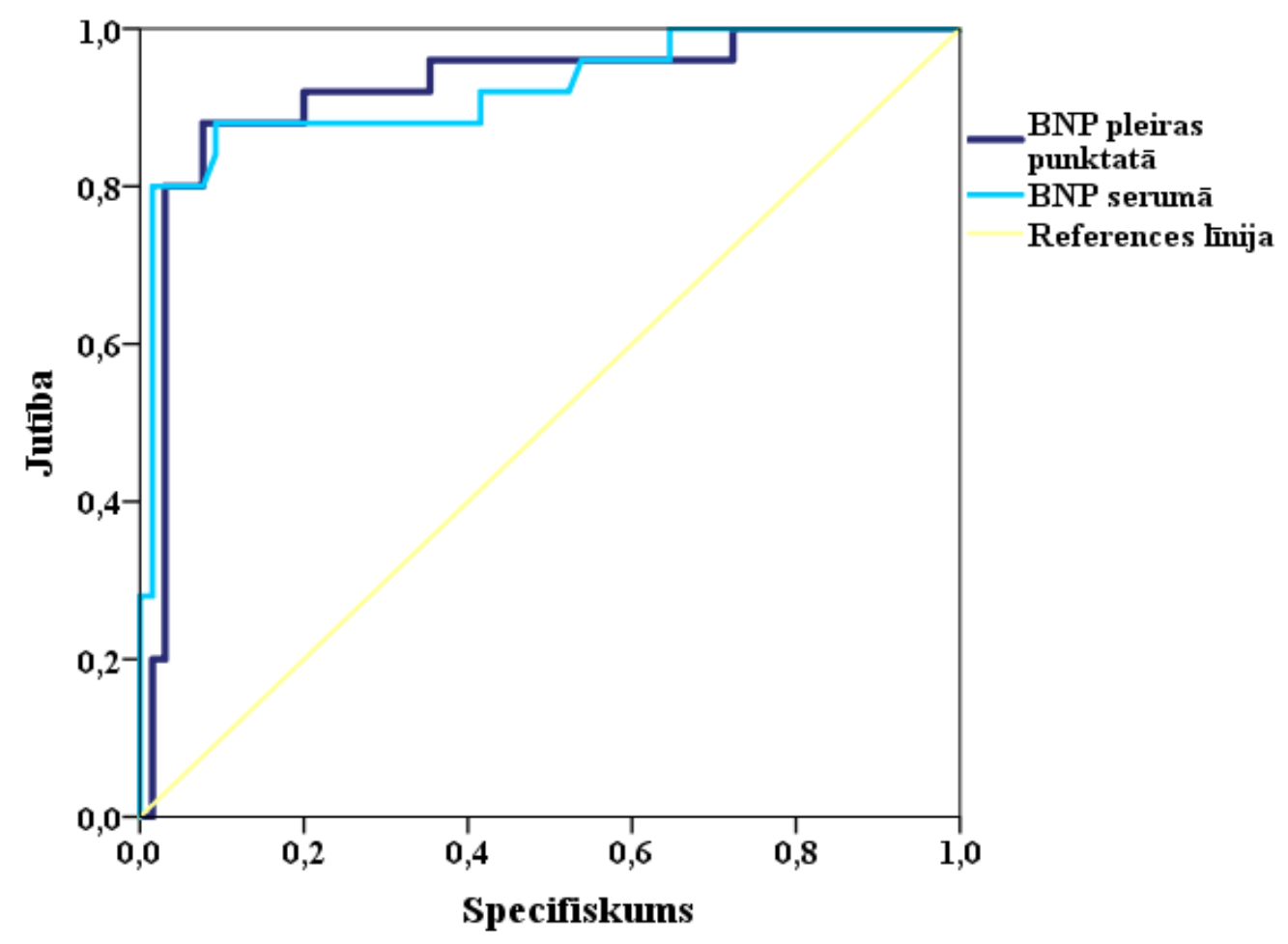

5.12. att. BNP ROC līkne zemlīknes laukums (Area ander the curve)

5. 10. tabula

BNP zemlīknes laukuma (area ander the curve) aprēḳins

\begin{tabular}{|l|l|l|l|l|l|}
\hline \multirow{2}{*}{ Rādītājs } & \multirow{2}{*}{$\begin{array}{c}\text { Zemlīknes } \\
\text { laukums }\end{array}$} & \multirow{2}{*}{ SE } & \multirow{2}{*}{$\begin{array}{c}\text { Būtiskuma } \\
\text { līmenis }\end{array}$} & \multicolumn{2}{|c|}{ 95\% TI } \\
\cline { 5 - 6 } & & & & Apakšējāà & Augšèjā \\
\hline BNP pleiras punktātā & 0,921 & 0,036 & $<0,001$ & 0,851 & 0,991 \\
\hline BNPserumā & 0,921 & 0,037 & $<0,001$ & 0,849 & 0,993 \\
\hline
\end{tabular}

SE - standartkḷūda; $95 \%$ T.I. - ticamības intervāls $95 \%$ robežās

Lai spriestu par audzēju marḳieru klīnisko nozīmi, tika aprēḳināta jutība un specifiskums gan marķieru līmeņiem serumā un punktātā, gan arī to punktāta/seruma attiecībai (5.11. tabula). Pēc tabulas redzams, ka visaugstākā jutība ir pie viszemākām robežvērtībām gan punktātā, gan serumā. Ja punktāta BNP $\geq 494 \mathrm{pg} / \mathrm{ml}$, tad jutība ir 76,9\%, savukārt specifiskums -96,8\%; bet, ja seruma $B N P \geq 971 \mathrm{pg} / \mathrm{ml}$, jutība ir 73,1\%, savukārt specifiskums $-95,9 \%$. 
5.11. tabula

BNP jutība un specifiskums transudātos

\begin{tabular}{|c|c|c|c|c|}
\hline Marķieris & Substrāts & Robežvērtība & Jutība (\%) & $\begin{array}{c}\text { Specifiskums } \\
(\%)\end{array}$ \\
\hline \multirow{6}{*}{$\mathrm{BNP}(\mathrm{pg} / \mathrm{ml})$} & \multirow{3}{*}{ Punktāts } & $\geq 494$ & 76,9 & 96,8 \\
\hline & & $\geq 1097$ & 50,0 & 97,3 \\
\hline & & $\geq 1582$ & 24,0 & 97,3 \\
\hline & \multirow{3}{*}{ Serums } & $\geq 971$ & 73,1 & 95,9 \\
\hline & & $\geq 1631$ & 50,0 & 95,9 \\
\hline & & $\geq 3386$ & 23,1 & 97,3 \\
\hline
\end{tabular}

\subsubsection{PAI-1}

PAI-1 līmeṇa mediāna pleiras punktātā (ng/ml): transudātu grupai 135 (20-236); malignu eksudātu grupai 188 (73-287); parapneimonisku pleirītu grupai 291 (213-499). PAI1 līmeņa atšķirība starp parapneimonisku pleirītu un malignu pleiras eksudātu bija statistiski ticama $-\mathrm{p}<0,001$, bet starp transudāta un malignu eksudāta PAI-1 vērtībām nav statistiski ticamas atšķirības $-\mathrm{p}=0,07$. Arī transudāts un parapneimonisks eksudāts savā starpā atškīīās statistiski ticami $(\mathrm{p}<0,001)-5.13$. attēls.

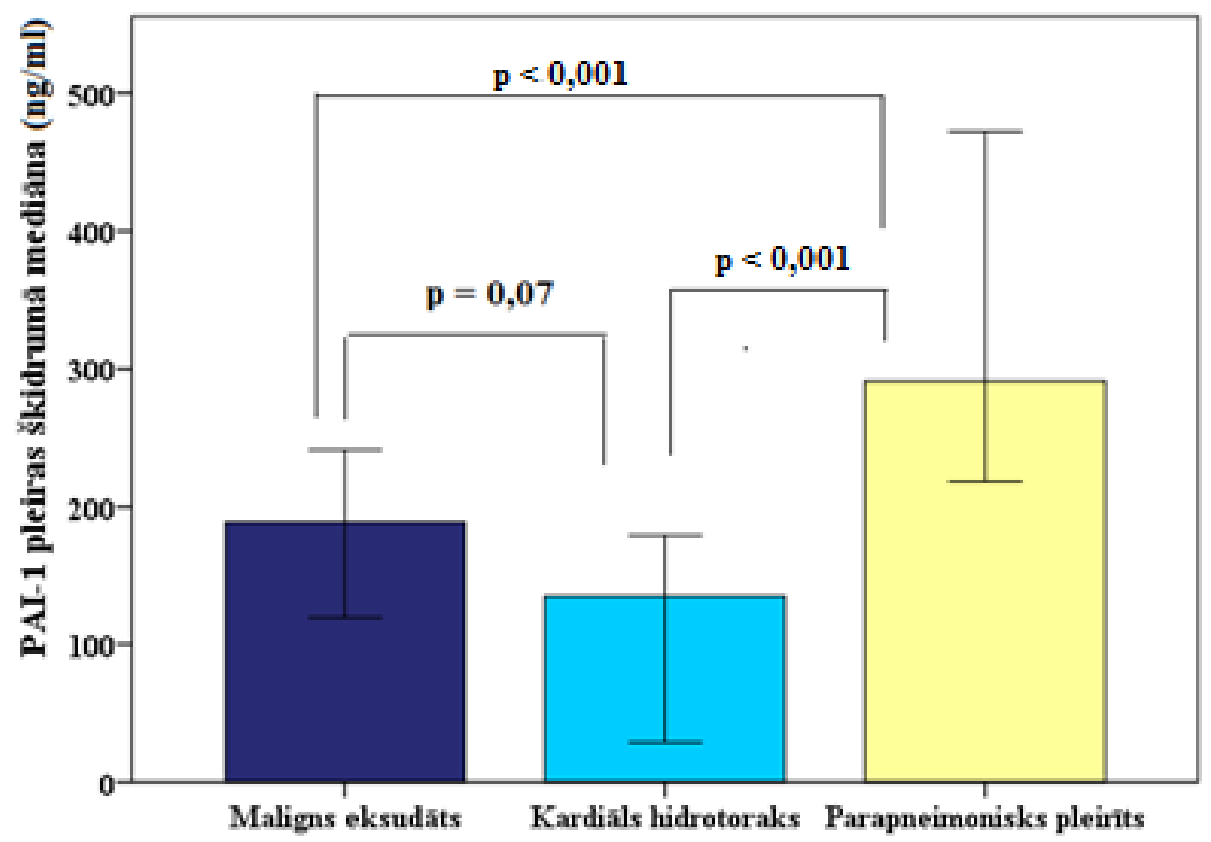

5.13. att. PAI-1 līmenis pleiras šḳidrumā 
PAI-1 līmenis (ng/ml) serumā pacientiem ar MPE bija 144 (77-207), pacientiem ar kardiālu hidrotoraksu - 69 (34-166), bet parapneimonisku pleirītu grupā - 204 (151-412). Arī serumā statistiski ticama bija atškirīiba starp parapneimoniska pleirīta un MPE grupām $(\mathrm{p}=0,003)$ un parapneimoniska pleirīta un kardiāla hirotoraksa grupām $-<0,001$, bet MPE un transudāta grupas savā starpā statistiski ticami neatšḳ̂īās - p =0,052) - 5.14. attēls.

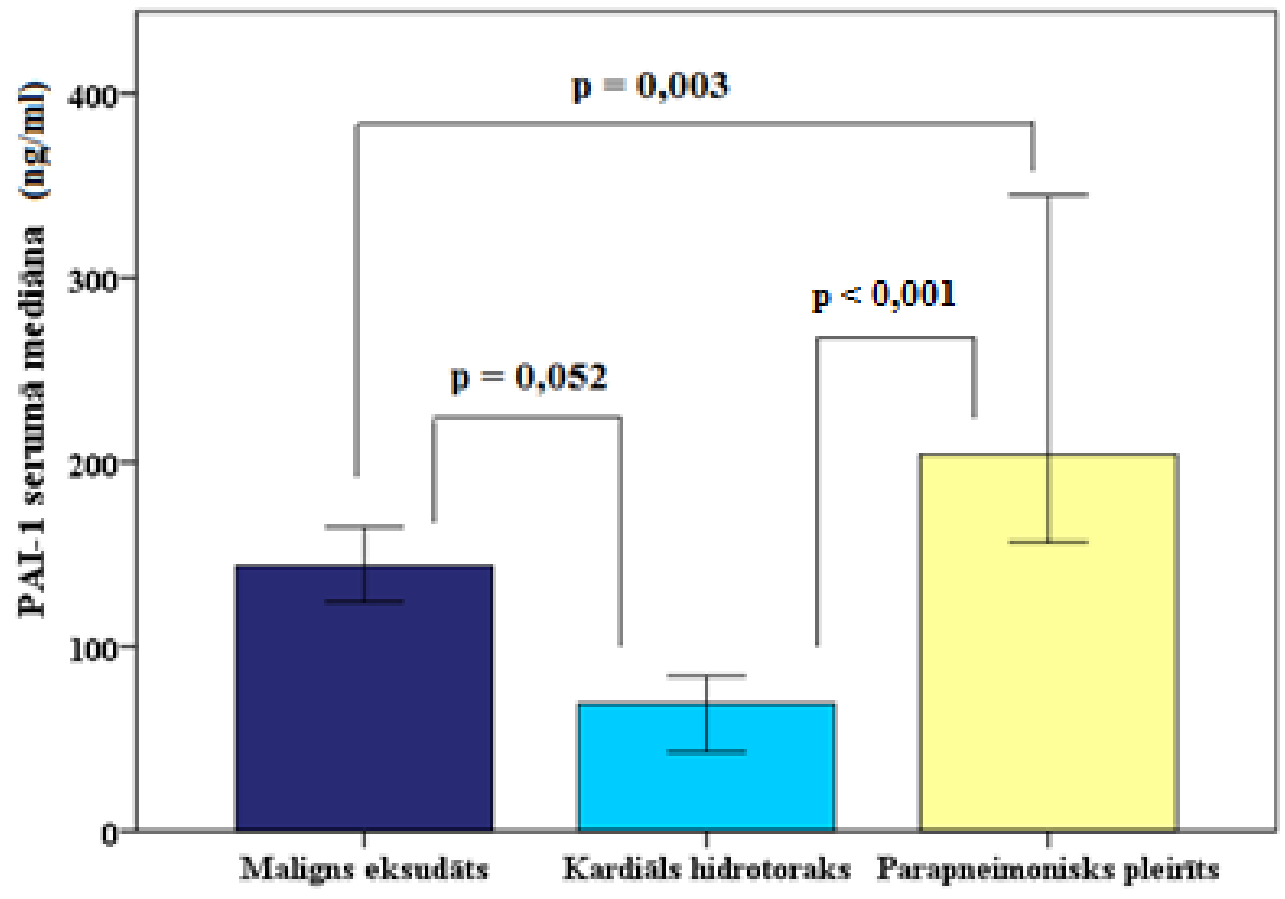

5.14. att. PAI-1 līmenis serumā

\subsubsection{Talka pleirodēze}

Talka pleirodēzes tika veiktas 11 pacientiem ar MPE (16,7\%). Pārējiem MPE pacientiem talka pleirodēze netika veikta vispārējā smagā stāvokḷa dēl (45-68,1 \%) un pacientu atteikuma dēl, (10-15,2\%). Mazā pacientu skaita dẹl talka pleirodēzes pacientu grupa tālāk analizēta netika. 


\section{DISKUSIJA}

Mūsu veiktajā pētījumā galvenais mērḳis bija noskaidrot, vai iespējams izmantot papildus bioķīmiskos marķierus, lai diagnosticētu MPE situācijā, kad MPE izmeklēšanas zelta standarts - videoasistēta torakoskopija nav pieejama, kā tas ir vairumā Latvijas slimnīcu. Lai saprastu, cik aktuāla ir MPE problēma slimnīcā un kā tie tiek diagnosticēti, vispirms veicām retrospektīvu datu analīzi par to, kā pacienti ar šķidrumu pleiras dobumā tiek izmeklēti, kādas diagnozes šiem pacientiem tiek noteiktas, cik procenti no tiem ir MPE un kādā veidā tie tiek pierādīti. Pēc tam, prospektīvi analizējot pacientus ar šķidrumu pleiras dobumā, kuri tika stacionēti pulmonologijijas nodaḷā, izvērtējām papildus bioḳīmisko marķieru (CA 125, CEA, PAI-1 un BNP) diagnostisko nozīmi MPE diferenciāldiagnostikā. Konstatējām, ka retrospektīvi analizētajā periodā analizētajā periodā trūkst konsekvences izmeklēšanas metožu izvēlē, kaut gan medicīnas literatūrā nepieciešamās izmeklēšanas metodes un algoritmi ir labi definēti un aprakstīti. Konstatējām faktu, ka 4,6 \% no visiem gada laikā ārstētiem pacientiem ir bijis šķidrums pleiras dobumā, kā arī to, ka pacientiem ar šķidrumu pleiras dobumā mirstība ir 3 reizes augstāka nekā pacientiem bez šķidruma pleiras dobumā. Visbiežākais cēlonis šķidrumam pleiras dobumā ir kardiāls hidrotorakss un to ticami var diferencēt, nosakot BNP līmeni asinīs. MPE diagnostikā kā papildus marḳieris vislabāk var kalpot CA 125 pleiras punktātā, bet PAI1 līmenis, iespējams, norāda uz aktivizētiem fỉbrinolīzes procesiem MPE salīdzinot ar parapneimoniskiem pleirītiem.

\subsection{Pleiras šḳidruma epidemiolog̣ija un etiolog̣ija}

Pētījumā tika konstatēts, ka no visiem slimnīcas "Gaiḷezers” terapeitiska profila nodaḷās ārstētajiem pacientiem 4,6 \% ir šķidrums pleiras dobumā. Nav statistiski nozīmīgas atšķirības starp saslimušajiem vīriešiem un sievietēm, bet pēc mūsu pētījumā iegūtajiem datiem redzams, ka pleiras šķidrums visbiežāk konstatējams cilvēkiem pēc 40 gadu vecuma - 95,8 \% no saslimušajiem, ir vecāki par 41 gadu, jādomā, tāpēc, ka, pieaugot vecumam, pieaug arī risks saslimt ar sirds asinsvadu un ḷaundabīgām slimībām, kas ir visbiežākie pleiras ṣ̌kidruma iemesli. Mūsu iegūtajos datos izvērtējot pacientu skaitu pa mēnešiem, var konstatēt, ka visvairāk pacientu stacionēti janvārī, martā, septembrī un oktobrī. Savukārt jūlijā stacionēto pacientu skaits ir vismazākais. Jādomā, ka šādas atšķirības saistāmas galvenokārt ar dziḷo elpceļu infekciju un parapneimonisku pleirītu lielāku skaitu ziemas un rudens mēnešos. Nekur citur literatūrā šādu datu analīzi neatradām. 
Izvērtējot izrakstīšanās diagnozes, 312 (43,6 \%) pacientiem šķidrums bija labās puses pleiras dobumā, $110(15,4 \%)$ - kreisās puses, 224 (31,3\%) - abpusējs un 70 (9,8\%) pacientiem pleiras dobuma šḳidruma lokalizācija nebija precizēta. Domājams, ka informācijai, vai šķidrums ir kreisajā vai labajā pleiras dobumā lielākoties nav klīniskas nozīmes, jo dati par konkrētas lokalizācijas šķidruma saistību ar kādu konkrētu patologiiju literatūrā nav atrodami.

N̦emot vērā to, ka šķidrums pleiras dobumā parasti ir kādas citas slimības komplikācija, incidences un prevalences aprēḳināšana ir ḷoti grūts uzdevums un ir ḷoti maz pētijjumu, kuros mēǵināts apkopot šāda veida epidemioloǵiskos datus. Viens no vislabāk organizētajiem pleiras šķidruma epidemioloǵiskajiem pētījumiem ir Miloslav Marel 1988. gadā Bohēmijā veiktais pētījums (Marel et al., 1993). Pētījuma mērḳis bija atklāt pacientus ar šķidrumu pleiras dobumā gan dzīves laikā, gan pēc nāves un konstatēt pleiras šķidruma incidenci un etioloǵiju. Pētījuma pacienti tika atlasīti pēc konkrētiem kritērijiem stingri noteiktā reǵionā. Kopā viena gada laikā 142 pacientiem (gan dzīviem, gan mirušiem) tika konstatēts šķidrums pleiras dobumā. 45,8 \% no visiem pacientiem tas bija kardiālas ǵenēzes, $21,8 \%$ no visiem pacientiem bija MPE, $17 \%$ no visiem pacientiem bija parapneimonisks pleirīts, 5,6 \% no visiem pacientiem šķidrums pleiras dobumā bija plaušu artērijas trombembolijas dẹl, 4,2 \% no visiem pacientiem bija hemotorakss. Tika aprēķināta incidence - 32 pleiras šķidruma gadījumi uz 100000 iedzīvotāju.

Mūsu pētījumā retrospektīvi tika analizētas 716 stacionāra medicīniskās kartes ar izrakstīšanās diagnozē minētu pleiras šķidrumu, bet nebija iespējams precīzi definēt reǵionu, no kura šie pacienti stacionēti, tāpēc incidenci aprēḳināt šin̄̄ pētījumā nevar, tomēr kopumā mūsu iegūtie dati ir salīdzināmi ar Marel iegūtajiem datiem. Visbiežākais cēlonis šķidrumam pleiras dobumā bija sirds mazspēja - pēc izrakstīšanās diagnozes, kardiāls hidrotorakss bija 426 (59,5 \%) pacientiem. Otrais biežākais cēlonis, tāpat kā Marel pētījumā, bija MPE - 103 $(14,4 \%)$ pacientiem, trešais cēlonis - parapneimonisks pleirīts - $71(9,9 \%)$ pacientam un pleiras empiēma - $30(4,2 \%)$ pacientiem.

Kolēg̣i Kauṇā (Zablockis et al., 2002) gadā analizēja 220 pleiras šḳidruma gadījumus. Transudāti tika konstatēti 24 \% gadījumu, bet eksudāti - 76 \% gadījumu. Kardiāli hidrotoraksi konstatēti $14,5 \%$, nefrotisks sindroms - 5,5\% gadījumu, aknu cirozes izraisīts transudāts $-2,5 \%$ gadījumu, parapneimonisks pleirīts - $13 \%$, pleiras empiēma - 9\%, tuberkuloze $-6 \%$, bet MPE 16,5 \% gadījumu. 5,5 \% gadījumu konstatēja PATE ar eksudātu pleiras dobumā (Zablockis et al., 2002). Mūsu gadījumā retrospektīvajā pētījumā kardiālu hidrotoraksu bija ievērojami vairāk - 59,5 \%, kas izskaidrojams ar to, ka pētījumā tika iekḷautas arī kardiolog̣ijas nodaļas, savukārt prospektīvajā pētījuma daḷā, kurā tika analizēti tikai Pulmonologiijas nodaḷas pacienti, kardiāli hidrotoraksi līdzīgi kā Kauņas kolēǵu pētījumā bija 
29,2 \%. Retrospektīvā pētījumā MPE bija 14,4 \% pacientu līdzīgi kā Kauņas kolēǵiem, bet prospektīvi analizēto pacientu vidū MPE bija ievērojami vairāk - 46 \%, kas arī izskaidrojams ar specializētu stacionēšanas nodaļu. Parapneimonisks pleirīts un pleiras empiēma bija līdzīgā skaitā gadījumu - retrospektīvā pētījumā attiecīgi 9,9 un 4,2 \%. Savukārt tuberkulozs pleirīts retrospektīvi analizētajos datos bija tikai 0,8 \% gadījumu, bet prospektīvi analizētajā pacientu grupā - 3,5 \% gadījumu, kas arī izskaidrojams ar stacionēšanu specializētā nodạ̦ā. PATE izraisīts pleiras eksudāts retrospektīvi analizētajā grupā bija tikai $1 \%$ gadījumu, bet prospektīvajā pētījumā - tikai 1 pacientam. Nemot vērā iepriekš aprakstīto pētījumu datus, kuros PATE pleirīti konstatēti ap 5 \% gadījumu, kā arī Broaddus (2016) aprēķinus par PATE pleirītu biežumu, var apgalvot, ka PATE RAKUS “Gaiḷezers” analizētajā periodā varētu būt diagnosticēta pārāk reti.

Valdes ar kolēǵiem 1996. gadā veica prospektīvu pētījumu noteikta reǵiona stacionāros Spānijā. Piecu gadu laikā viņi 642 pacientiem (no tiem 401 vīrietis; pacientu vidējais vecums 57 gadi) atklāja šķidrumu pleiras dobumā. Šajā reǵionā visbiežākais pleiras eksudāta cēlonis bija tuberkuloze (25\%), malignitāte (22,9\%) un hroniska sirds mazspēja (17,9\%). Malignitātes grupā visbiežākais MPE cēlonis bija plaušas audzējs - 32\% gadījumu, krūts audzējs - 11,5 \% gadījumu, limfoma - 10,8 \% gadījumu un olnīcu audzējs - 7,5 \% gadījumu. 14,3 \% gadījumu primāro audzēju nevarēja identificēt. 69,4\% no tuberkuloza pleirīta pacientiem sastādīja pacienti, kas bija jaunāki par 40 gadiem, bet MPE pacienti 83 \% gadījumu bija vecāki par 50 gadiem (Valdes et al., 1996). Mūsu valstī tuberkulozes izplatība ir ievērojami augstāka nekā Spānijā - Latvijā jaunu un jau ārstētu tuberkulozes gadījumu skaits uz 100000 iedzīvotāju 2010. gadā bija 20-50, bet Spānijā - 10-19 (Dara et al., 2013), tomēr tuberkulozu pleirītu mūsu apstrādātajos datos ir daudz mazāk, kas skaidrojams ar specializētu tuberkulozes diagnostikas un ārstēšanas slimnīcu esamību Latvijāa Novērojamas arī būtiskas pacientu vecuma atšḳirības - retrospektīvi analizētajā pacientu izlasē jaunāki par 41 gadu bija tikai 4,2 \% pacientu, bet modālais pacientu vecums bija 71-80 gadi, ko var izskaidrot ar to, ka tuberkulozs pleirīts galvenokārt sastopams jauniem cilvēkiem, savukārt sirds mazspēja un ḷaundabīgas slimības - vecākiem. Prospektīvi analizētajā grupā MPE sadalījums pa primāro audzēju grupām bija līdzīgs - 37 \% gadījumu tas bija plaušu vēzis, $20 \%$ - krūts vēzis un $20 \%$ - olnīcu vēzis. Pacienti ar MPE limfomas dēḷ netika novēroti, jādomā, tādēl, ka pacienti ar hematologiskām slimībām Latvijā galvenokārt tiek stacionēti specializētā nodāḷā.

Pētījumā, kurā tika iesaistīti 1000 pacientu un kuriem tika veikta pleiras dobuma punkcija, Villena Garrido ar līdzstrādniekiem 36 \% gadījumu (364 pacientiem) konstatēja MPE (Villena Garrido et al., 2002). Mūsu retrospektīvajā pêtījumā no 272 pacientiem, kuriem bija 
veikta pleiras punkcija, tikai 14,7 \% konstatēja MPE, kas ir ievērojami mazāk, bet prospektīvajā pētījumā specializētajā nodaḷā MPE bija 46,5 \%, kas, iespējams, varētu liecināt par malignu pleiras šķidrumu hipodiagnostiku stacionārā kopumā un labāku MPE diagnostiku specializētā nodaḷā.

Čehijā tika veikts pētījums, kurā tika iekḷauti pacienti, kuri 4 gadu laikā bija stacionēti plaušu slimību profila slimnīcā Prāgā. 44,6 \% gadījumu tika konstatēts MPE pleiras dobumā, $11,7 \%$ bija parapneimonisks šķidrums, 6,4\% - empiēma, 6,4\% - tuberkulozs pleirìts (Loddenkemper et al., 2002), kas ir salīdzināms ar mūsu prospektīvā pētījuma datiem Pulmonologijas nodal̦ā, kur 46,5 \% pacientu konstatēja MPE un 18,8 \% - parapneimonisku pleirītu, savukārt 3,5\% pacientu - tuberkulozu pleirītu.

Svarīgi atzīmēt, ka kopējā letalitāte stacionāra "Gaiḷezers" terapeitiskā profila nodaḷās gada laikā bija 4,4 \%, bet pacientiem, kuriem izrakstī̌sanās diagnozē minēts šḳidrums pleiras dobumā, letalitāte bija vairāk kā trīs reizes augstāka - 14,1 \%, kas statistiski ticami $(\mathrm{p}<0,001)$ norāda uz pleiras patologijas pacientu ievērojami augstāko risku. Šāda veida dati šobrīd pasaules literatūrā nav atrodami.

\subsection{Pleiras šḳidruma diagnostikas metodes}

Mēs retrospektīvi analizējām izmeklējumus, kādi veikti pacientiem ar šķidrumu pleiras dobumā. Tika konstatēts, ka visbiežāk veiktais izmeklējums ir krūšu kurvja rentgenogrāfija - 90,9 \%, bet pleiras dobuma ultrasonoskopija vēsturēs tika dokumentēta tikai 19,7 \% no visiem gadījumiem. Savukārt 5,9 \% pacientu netika veikta ne krūšu kurvja rentgenogrāfija, nedz arī datortomogrāfija.

Teorētiski visiem pacientiem, kuriem pirmo reizi mūžā konstatēts šķidrums pleiras dobumā un kuriem klīniski nav pārliecinošu datu par transudātu (sirds vai aknu mazspējas dekompensācija vai zināma nieru slimība), būtu jāveic pleiras dobuma punkcija (Havelock et al., 2010; Villena Garrido et al., 2014). Pēc mūsu pêtījumā analizētās medicīniskās dokumentācijas datiem, no 716 pacientiem punkcija tika veikta 272 (38\%). $74 \%$ pacientu no tiem, kuriem nebija veikta punkcija, izrakstīšanās diagnozē tika minēts kardiāls hidrotorakss, bet 116 pacientiem (26 \%) pleiras šķidrums netika saistīts ar kardiālu patoloǵiju, tomēr punkcija veikta netika. Jāatzīmē arī, ka tikai 22,8 \% mirušo pacientu tika veikta pleiras dobuma punkcija, kas, jādomā, tomēr liecina par pārāk konservatīvu taktiku. Izvērtējot rezultātus, konstatēts, ka visbiežāk (60,2 \%) punkcija veikta pacientiem ar malignas dabas eksudātu izrakstīšanās diagnozē, bet visretāk pacientiem ar kardiālu hidrotoraksu - (23\%). Tendence atzīstama par 
pareizu, tomēr nepunktēto pacientu skaits liek domāt par nepietiekamu klīnisko datu, t.sk., pleiras punktāta bioḳīmiskā sastāva analīzi un līdz ar to par iespējamām diagnostiskām kḷūdām.

Gadījumos, kad ir indikācijas punktēt pleiras dobumu, tas būtu jādara pēc iespējas drīzāk vai neatliekami gadījumā, ja pacientam ir elpošanas nepietiekamība vai aizdomas par pleiras empiēmu, bet pārējos gadījumos punkcija jāveic laikā, kad pieejams apmācīts speciālists (Havelock et al, 2010), jo nereti tikai no svaiga pleiras ş̧̧idruma laboratorās analīzesvar gūt pareizu un diagnostiski vērtīgu informāciju. Š̄i brīža nostādne paredz, ka pleiras dobuma punkcija jāizdara pieredzējušam speciālistam atbilstošos apstākḷıos (ultrasonoskopijas iespējas, komplikāciju novēršanas iespējas), tātad parasti darba dienas laikā. Invazīvām procedūrām, kuras bez stingrām indikācijām tiek veiktas pēc pusnakts, parasti ir vairāk komplikāciju (Havelock et al., 2010, Feller-Kopman et al., 2018), tomēr ilga vilcināšanās, it sevišķi parapneimonisku pleirītu gadījumos, nav ieteicama, ņemot vērā faktu, ka parapneimonisks pleirīts var komplicēties ar fibrīna septām un pleiras empiēmu pat 12 stundu laikā (Villena Garrido et al., 2014; Davies et al, 2010). Mūsu veiktajā pētījumā pēc retrospektīvi analizeto datu analīzes tikai 71 pacientam (26,1 \% no punktētajiem pacientiem) pleiras punkcija veikta pirmajā dienā, 53 (19,5 \% no punktētajiem pacientiem) - otrajā dienā pēc iestāšanās, pārējiem pacientiem pleiras dobuma punkcija tika veikta vēlāk, arī laika posmā no 14-30. dienai pēc iestāšanās, kas varētu liecināt par novēlotiem diagnostiskiem un ārstnieciskiem pasākumiem un nepietiekami agresīvu taktiku, kas noved pie ilgāka laika, ko pacients pavada slimnīcā, iespējamām komplikācijām un izmaksu pieauguma.

Pēdējās desmitgadēs arvien vairāk tiek uzsvērts, ka pleiras dobuma punkcijai nepieciešama ultrasonoskopijas kontrole - vai nu pirms punkcijas vai arī punkcijas laikā, turklāt iepriekšēja punkcijas vietas atzīmēšana citā telpā vai nodaḷā netiek rekomendēta. Visaugstākais komplikāciju risks ir ārstam, kurš nav trenēts punkciju veikšanā un kurš neizmanto ultrasonsokopijas metodi - 15 \% gadījumu attīstās pneimotorakss, 4,7 \% nepieciešama pleiras dobuma drenāža un 12,9 \% gadījumu punkcijas laikā neizdodas iegūt šķidrumu (Havelock et al., 2010, Feller-Kopman et al., 2018). Salīdzinājumam trenētam ārstam, kurš izmanto ultrasonoskopiju, attiecīgie riski ir 3,6 \%; 0,9\% un 2,7 \%. Mūsu retrospektīvjā analīzē no 272 veiktajām punkcijām tikai 104 gadījumos tika veikta ultrasonoskopija. Pavisam ultrasonoskopija tika veikta 141 pacientam (19,7\%), kas liecina, ka ultrasonoskopijas metode netiek pietiekami izmantota. Dati par pleiras dobuma punkcijas komplikācijām mūsu pētījumā netika apkopoti.

Šādi dati, mūsuprāt, liecina par nepietiekamu diagnostisko metožu izmantošanu izvērtētajā periodā stacionārā "Gaiḷezers". 
Literatūrā publikācijas par šādā veidā analizētajiem datiem netika atrastas, iespējams, tāpēc, ka, pat ja šādi dati tiek analizēti, tie vairāk kalpo slimnīcas iekšējās kvalitātes kontroles sistēmai. Arī mūsu uzdevums, retrospektīvi analizējot pacientu vēstures, bija konstatēt esošo stāvokli slimnīcā un saprast, kādā veidā to var uzlabot.

\section{Pleiras šḳidruma laboratorās izmeklēšanas metodes}

\subsubsection{Bioḳīmiskās izmeklēšanas metodes}

Izvērtējot, kādam būtu jābūt pleiras punktāta izmeklējumu minimumam, jāvadās pēc klīniskās ainas. Saskaṇā ar Light un citu autoru norādījumiem (Sahn, 2003; Havelock et al., 2010; Broaddus et al., 2016), gadījumos, kad ir augsta transudāta iespējamība, piel̦aujams noteikt tikai LDH un olbaltumvielas pleiras šķidrumā un serumā jeb t. s. Laita kritērijus. Ja olbaltumvielas pleiras punktātā/olbaltumvielas serumā $<0,5 ; \mathrm{LDH}$ pleiras punktātā/LDH serumā $<0,6$ un LDH pleiras punktātā $<2 / 3$ no konkrētās laboratorijas normas augšējās robežas serumā, tas ir transudāts un nav nepieciešama tālāka izmeklēšana.

Laita kritēriji šobrīd ir galvenā metode, kuru izmanto transudātu un eksudātu diferencēšanai. Tā kā tālākā taktika transudātu un eksudātu gadījumos ir radikāli atškikirīga, tad šo kritēriju nozīmi nevar pārvērtēt. Abās pieejamās vadlīnijās par šḳidrumu pleiras dobumā Laita kritēriji tiek minēti kā obligāti veicami, turklāt, lai Laita kritērijus varētu pilnvērtīgi izvērtēt, olbaltumvielas un LDH jānosaka ne tikai pleiras punktātā, bet arī asin̄̄s (Hooper et al., 2010; Villena Girrargo et al, 2014).

Laita kritēriji pirmo reizi publicēti 1972. gadā un līdz šim brīdim, neskatoties uz daudziem mēgénājumiem un pētījumiem šinī jomā, labāka metode tomēr nav atrasta un Laita kritēriji joprojām tiek izmantoti kā zelta standarts citu marḳieru izpētē. Laita kritēriju diagnostiskā jutība eksudātiem ir ap $98 \%$, bet vidēji $25 \%$ transudātu var tik nepareizi diagnosticēti kā eksudāti un galvenokārt tas novērojams pacientiem pēc diurētisko līdzekḷu terapijas. Šādiem pacientiem rekomendē aprēḳināt seruma - pleiras šķidruma olbaltumvielu gradientu: seruma olbaltumvielu līmenis mīnus pleiras šķidruma olbaltumvielu līmenis. Ja šis gradients ir lielāks par $31 \mathrm{~g} / \mathrm{L}$, šḳidrums ar lielāko varbūtību ir transudāts. Ja gradients ir mazāks par $31 \mathrm{~g} / \mathrm{L}$, jānosaka vai nu NT-proBNP serumā vai punktātā vai arī albumīna seruma - pleiras punktāta albumīna gradients. Ja Nt-proBNP ir lielāks par 1300 pg/L vai, ja albumīna gradients ir lielāks par 12 g/L, šķidrums ir transudāts (Porcel et al., 2004; Bielsa et al., 2012; Light R.W., 2013). 
Ja klīniskā aina liecina par iespējamu eksdudātu (nav sirds, aknu vai nieru mazspējas pazīmes, ir aizdomas par malignitāti, pneimoniju vai plaušu artēriju trombemboliju), papildus jānosaka punktāta klīniskā analīze un $\mathrm{pH}$. Ja pleiras škidruma $\mathrm{pH}<7,3$, bet asiṇu pH ir normāls, tad eksudatīva pleiras šḳidruma gadījumā jādiferencē starp komplicētu parapneimonisku pleirītu vai empiēmu, malignitāti, barības vada ruptūru, reimatoīdu pleirītu, lupus pleirītu un tuberkulozu pleirītu. Vien̄̄gais transudāts ar normālu pH vērtību ir urinothorax saistībā ar tās pašas puses obstruktīvu uropātiju (Sahn, 2003, Havelock et al., 2010, Villena Girrado et al., 2014). Ja pH noteikt nav iespējams tehnisku iemeslu dēl, var vadīties pēc klīniskās ainas vai arī noteikt glikozes līmeni. Ja pleiras virsma ir vesela, tad glikozes līmenis pleiras punktātā ir vienāds ar glikozes līmeni serumā. Zems glikozes līmenis parasti liecina par bakteriālu infekciju, reimatoīdu artrītu vai tuberkulozu pleirītu, malignitāti vai barības vada ruptūru. Glikoze $<1,5 \mathrm{mmol} / 1$ parasti ir pleiras empiēmas un reimatoīdā astrīta gadījumos. Ja glikoze ir $<3,4 \mathrm{mmol} / \mathrm{l}$, tas ir kritērijs pleiras dobuma drenāžas uzsākšanai (Hooper et al., 2010).

Mūsu pētījumā retrospektīvi analizējot datus, tika konstatēts, ka pleiras punktāta analīžu kombinācijas ir ḷoti dažādas. Visbiežāk - 130 (47 \%) gadījumu - vienlaicīgi noteiktas klīniskā analīze, LDH, olbaltumvielas un citologiija. Pārējās analīzes un analīžu kombinācijas noteiktas ievērojami retāk. $29(10,7$ \%) gadījumos pleiras punktāta analīzes netika veiktas vispār. Nevienā no gadījumiem netika izvērtēta olbaltumvielu līmeṇa attiecība pleiras šḳidrumā un asinīs un LDH attiecība pleiras šķidrumā un asin̄̄s, kas apliecina ārstu vājo izpratni par transudāta un eksudāta diferenciāldiagnostikas būtiskumu. Svarīgi atzīmēt, ka 98 gadījumos (36\% no punktētajiem pacientiem) nebija noteikts LDH, kas ir svarīgākais parametrs transudāta un eksudāta diferencēšanā (Light, 2013). Tāpat jāatzīmēe ka nevienam pacientam pleiras šķidrumā netika noteikts pH, kas gan, iespējams, izskaidrojams ar tehniskām grūtībām izmantot gāzu analizatoru. Mūsuprāt, apstākḷıs, kad pH noteikšana gāzu analizatorā ir tehniski sarežǵīta (liels attālums līdz laboratorijai un personāla trūkums, lai pietiekami ātri nogādātu paraugu laboratorijā), tā vietā pilnīgi pieḷaujama arī glikozes noteikšana pleiras dobuma šķidrumā. Tomēr pēc analizētajiem datiem, tikai vienā gadījumā no 272 bija noteikta glikoze, sešos gadījumos bija noteikta lipāze. Parietālās pleiras biopsija veikta deviņos $(1,3 \%)$ pacientiem, pieciem no tiem konstatēts tuberkulozs pleirīts. Torakoskopija tika veikta tikai diviem $(0,3 \%)$ pacientiem, kas izskaidrojams ar to, ka analizētajā stacionārā nav torakālās ķirurğijas nodaḷas. Mums pieejamajā literatūrā neizdevās atrast pētījumus, kuros līdzīgā veidā tiktu analizēti stacionārā veiktie pleiras dobuma šķidruma izmeklēšanas veidi, tāpēc grūti spriest, vai stacionārs "Gaiḷezers" būtiski atšḳiras no citiem stacionāriem, tomēr ir skaidrs, ka analizētie dati liecina par nepietiekamu klīnisko rekomendāciju ievērošanu praksē. 
Prospektīvā pētîjumā visiem pacientiem tika noteikti Laita kritēriji. Konstatēts, ka kardiāls hidrotorakss bija 42 pacientiem, 34 (81\%) pacientiem Laita kritēriji atbilda transudātam, bet 8 (19\%) pacientiem Laita kritēriji atbilda eksudātam, kas precīzi atbilst iepriekšminētiem literatūrā (Porcel et al., 2004; Bielsa et al., 2012; Light R.W., 2013) aprakstītajiem secinājumiem. Veicot papildus aprēķinus, šiem pacientiem tika noteikts olbaltumvielu gradients. Septiniem pacientiem tas bija $>31 \mathrm{~g} / \mathrm{L}$, bet vienam pacientam tas bija $<31$ g/L, bet BNP serumā šim pacientam bija 1631 pg/ml. Parapneimoniska pleirīta grupā (29 pacienti) visiem pacientiem bija pozitīvs vismaz viens Laita kritērijs. Parapneimonisko pleirītu grupa visiem pacientiem bija pozitīvs arī trešais Laita kritērijs - LDH līmenis punktātā (1681006 U/L), kas liek domāt, ka parapneimonisku pleirītu gadījumos iespējams izmantot tikai 3. Laita kritēriju, papildus nenosakot LDH un olbatumvielas serumā. MPE grupā (67 pacienti), vismaz viens Laita kritērijs bija pozitīvs 65 (97,1\%) pacientiem, kas atbilst literatūrā aprakstītajiem datiem. Tikai 52 (77,6 \%) pacientu bija pozitīvs 3. Laita kritērijs, kas norāda uz to, ka neskaidras diagnozes gadījumā, it sevišķi, ja ir aizdomas par MPE, tomēr jāveic LDH un olbaltumviela noteikšana arī asins serumā.

\subsubsection{Leikocītu sastāvs}

Pēc Lielbritānijas torakālās asociācijas vadlīnijām, leikocītu šūnu procentuālā sastāva noteikšana var palīdzēt diferenciāldiagnostikā, bet tā nav specifiska nevienai no slimībām (Hooper et al., 2010). Šķidrumos, kas ilgstoši atradušies pleiras dobumā (tuberkuloze, malignitāte, transudāti) vairāk ir limfocītu jeb MMN šūnu, savukārt akūti veidojušos šķidrumos (parapneimnisks pleirīts) prevalē neitrofîlie leikocīti jeb PMN šūnas. Jauniem cilvēkiem (līdz 35 gadiem) ar limfocitāru eksudātu jāveic parietālās pleiras biopsija tuberkuloza pleirìta diagnostikai (Hooper et al., 2010).

Pēc mūsu iegūtajiem datiem, parapneimonisks pleirīts tiešām pēc PMN šūnu daudzuma atšķiras no transudātiem un MPE (mediānais PMN 70 \%, p < 0,001). MMN šūnu mediānais procentuālais sastāvs bija augstāks transudātiem - $78 \%$, bet MPE - $63 \%$, kas savstarpēji statistiski ticami neatšķīrās $(\mathrm{p}=0,416)$.

Pēdējā laikā, kā papildus marķieris pleirītu identifikācijā tiek pētīta arī neitrofîlo leikocītu/limfocītu attiecība pleiras puktātā. Ja tā ir augstāka par 0,75, ticama ir tuberkuloza pleirīta diagnoze, it sevišķi endēmiskos tberkulozes rajonos (Akturk et al, 2016). Neitrofīlo leikocītu / limfocītu attiecību perifērajās asin̄̄s pēdējā laikā izmanto arī kā prognostisku marķieri pacientiem ar ļaundabīgiem audzējiem - pētījumā ar mezoteliomas pacientiem neitrofîlo leikocītu/limfocītu attiecība lielāka par 5 bija statistiski ticams neatkarīgs sliktas 
prognozes faktors (Kao et al., 2010), bet dažādas lokalizācijas audzēju izraisītu MPE pacientiem neitrofîlo leikocītu / limfocītu attiecība, kas lielāka par 3 kopā ar sliktu pacienta funkcionālo stāvokli un audzēja histologisko tipu bija ticami sliktas prognozes marķieri (Anevlavis et al., 2014). Arī 2014. gadā publicētajā LENT skalā, kuru iesaka izmantot talka pleirodēzes indikāciju izvērtēšanai, viens no rādītājiem ir neitrofîlo leikocītu / limfocītu attiecība perifērajās asinīs. Šin̄̄ skalā pēc pēc vairāku MPE pacientu $(\mathrm{n}=789)$ analīzes slikta prognoze ir attiecībai, kas lielāka par 9 (Clives et al., 2014). Mūsu pētījumā mediānā leikocìtu / limfocītu attiecība pleiras punktātā MPE grupā bija 1,7, transudātu grupā - 3,55, bet parapneimonisku pleirītu grupā-0,43. MPE limfocītu un neitrofīlo leikocītu attiecība statistiski ticami neatšķ̄īās no transudātiem un parapneimoniskiem pleirītiem (attiecīgi $p=0,170$ un 0,078), bet satatistiski nozīmīga attiecības atškirība bija starp transudātu un parapneimonisku pleirītu $(\mathrm{p}=0,004)$. Diemžēl mūsu pētījumā netika apkopoti dati par perifēro asiņu neitrofîlo leikocītu un limfocītu skaitu, bet tas varētu būt tālāku pētījumu vērts rādītājs.

\subsubsection{Citoloğija}

Citologiskā izmeklēšana ir plaši lietota metode MPE diagnostikā, tomēr tikai vidēji 60 \% gadījumu pleiras punktātā izdodas atrast malignas šūnas, turklāt paraugu atkārtota pleiras punktāta izmeklēšana nepaaugstina metodes jutību (Hooper et al., 2010). Citoloğiskāa izmeklēšana noteikti jâveic visiem pacientiem pēc 40 gadiem, tā kā pēc šì vecuma pieaug onkoloǵisko slimību risks (Rodriguez-Pandero et al.; 2006, Hooper et al, 2010). Mūsu pētījumā prospektīvi citologiskā pleiras šķidruma analīze tika veikta visiem pacientiem, malignas šūnas tika atrastas $44(65,7 \%)$ pacientu, $38(83,4 \%)$ no tiem tās atrada jau pirmajā paraugā, bet 6 $(13,6 \%)$ - nosūtot izmeklēšanai atkārtotu pleiras dobuma punktātu. Šie rezultāti kopumā atbilst publicētajiem datiem par citoloǵiskās izmeklēšanas jutību. Tiek diskutēts par to, vai metodes jutību paaugstina pleiras punktāta apjoms, kas tiek nosūtīts uz laboratoriju. Daži autori konstatējuši, ka daudzumam nav nozīmes (Wu et al., 2017; Sallach et al, 2002), tomēr daži uzskata, ka šķidruma daudzumam ir nozīme. Tā piemēram, Thomas ar kolēǵiem apkopoja rezultātus par 6 gadu laikā Aberdīnas citologískajā laboratorijā saņemtajiem 2155 pleiras punktāta paraugiem un konstatēja, ka adekvātai diagnozes noteikšanai nepieciešami vairāk kāa $25 \mathrm{ml}$ šḳidruma, bet šḳidruma daudzums, kas pārsniedz $50 \mathrm{ml}$, nepaaugstina metodes jutību (Thomas et al., 2011). Mūsu pētījumā uz citologisko analīzi tika nosūtīti $30 \mathrm{ml}$ punktāta un netika analizēta saistība starp nosūtītā punktāta daudzumu un pozitīvu citologijas atbildi. Metodes jutība ir atkarīga arī no citologa pieredzes, parauga sagatavošanas tehnikas un audzēja tipa (Hooper et al., 2010). 


\subsubsection{Bakterioloğija}

Bakterioloǵiskā izmeklēšana jāveic visos gadījumos, kad iespējams eksudāta infekciozas dabas cēlonis, tomēr jutība kopumā ir zema. Aptuveni 15-20 \% pleiras punktāta paraugu uzsējumā tika identificētas baktērijas (Mohanty et al., 2007; Broaddus et al., 2016). Mūsu gadījumā tikai 2 (7 \%) no 27 izmeklētajiem paraugiem uzsējumā identificēja baktērijas (Klebsiella pneumoniae un Staphylococcus saccrolyticus), kas ir mazāk nekā aprakstītajos literatūras datos. Tā kā metode ir salīdzinoši dārga un laikietilpīga, tad netiek rekomendēts bakteriologiski izmeklēt visus pleiras punktātus, bet gan vadīties pēc klīniskās ainas, kas varētu liecināt par bakteriālas infekcijas esamību (Broaddus et al., 2016). L,oti zemo metodes jutību mūsu gadījumā var skaidrot ar nepietiekami ātru paraugu nogādāšanu mikrobiologijas laboratorijā, tāpat iespējams, ka speciālo barotṇu izmantošana uzreiz pēc paraugu iegūšanas varētu būtiski uzlabot šīs metodes jutību.

Gadījumos, kad ar pleiras punktāta analīzi neizdodas noskaidrot eksudāta etioloǵisko faktoru, par visefektīvāko diagnostikas metodi mūsdienās tiek uzskatīta videotorakoskopija ar redzes kontrolē veiktu pleiras biopsiju. Tā kā visticamākais iemesls neprecizētas etiologijas šķidrumam pleiras dobumā ir agrīnas stadijas ḷaundabīga slimība (vēzis, limfoma, mezotelioma), retāk tuberkulozs pleirīts, nogaidošu taktiku izvēlēties nerekomendē (RodriguezPandero et al., 2006; Hooper et al, 2010; Villena Girrardo et al., 2014; Broaddus et al., 2016). Mūsu gadījumā torakoskopijas iespējas stacionārā bija ḷoti ierobežotas, tāpēc tā tika veikta tikai 2 no retrospektīvi analizētajiem gadījumiem un nevienā prospektīvi analizētajā gadījumā.

\subsubsection{Audzēju marķieri}

Ṇemot vērā faktu, ka pleiras punktāta citologiskai izmeklēšni ir samērā zema jutība, kā arī to, ka līdzīgi kā stacionārā "Gaiḷezers" arī daudzās citās pasaules slimnīcās ne vienmēr ir pieejama torakoskopija MPE vai citas diagnozes apstiprināšanai, l̦oti plaši tiek pētītas alternatīvas metodes, kas varētu palīdzēt diferencēt MPE no citas etiologijas eksudātiem. Audzēju marķieru līmenis pleiras punktātā ir viens no pētījumu virzieniem, kaut gan dažos pēdējos gados padziḷināti pētījumi vairs netiek rekomendēti (Feller-Kopman et al., 2018).

Choi un līdzautori (Choi et al, 2013) noteica CA 125 pleiras punktātā 326 pacientiem un pēc tam retrospektīvi analizēja tā līmeni pacientiem ar dažādas etioloğijas pleiras šķidrumu. Pētījumā konstatēts, ka CA 125 būtiski paaugstināts pacientiem ar malignas etiologiijas pleiras šķidrumu (vairāk nekā vienai trešdaḷai pacientu CA 125 bija > $600 \mathrm{U} / \mathrm{ml}$ ), bet statistiski būtiski neatšḳiras pacientiem ar transudātu un benignas etioloǵijas šḳidrumu pleiras dobumā. Pēc mūsu 
aprēķiniem, 1/3 MPE pacientu CA 125 līmenis ir augstāks par $813 \mathrm{U} / \mathrm{ml}$ un tā līmenis malignos eksudātos statistiski būtiski atšḳīrās gan no transudāta, gan no parapneimoniska pleirīta (attiecīgi $\mathrm{p}<0,001$ un $\mathrm{p}<0,002$ ).

\section{CEA un CA 125 robežvērtību, zemlīknes laukumu, jutības un specifiskuma salīdzinājums}

Feng un kolēgi analizēja CEA pleiras punktātā 156 pacientiem, 114 no tiem ar MPE, bet 42 ar tuberkulozu pleirītu. Pie robežvērtības 4,5 metodes jutība bija $75 \%$, bet specifiskums - $96 \%$ (Feng et al., 2016). Xu un kolēgi noteica CEA līmeni 60 malignos un 58 labdab̄̄gos pleiras šķidrumos, konstatējot, ka 54 pacientiem ar malignu pleiras eksudātu CEA līmenis pleiras punktātā ir lielāka par $5,5 \mathrm{ng} / \mathrm{ml}$ un pie šādas robežvērtības, kombinējot CEA ar tumora marķieri sRCAS, jutība bija 98,3 un specifiskums - 91,4 \%. (Xu et al., 2014), kas liecina par to, ka apvienojot dažādus diagnostiskus marḳierus, jutība paaugstinās. Pēc mūsu datiem pie robežvērtības $6,23 \mathrm{ng} / \mathrm{ml} \mathrm{ng/ml} \mathrm{CEA} \mathrm{jutība} \mathrm{bija} \mathrm{tikai} \mathrm{50,7} \mathrm{\%} \mathrm{un} \mathrm{specifiskums} 94,8 \%$, bet apvienojot CA 125 un CEA, to jutība bija 56,4 \%, bet specifiskums - 93,3\%.

Son un līdzautori analizēja 47 labdabīgus un 52 malignus pleiras eksudātus, salīdzinot audzēja marḳieru CD66c, CEA, CA 19-9 un CYFRA 21-1 pleiras punktātā diagnostiskās vērtības, konstatējot, ka pie robežvērtības $2,5 \mathrm{ng} / \mathrm{ml}$ visaugstākā diagnostiskā vērtība ir CEA - jutība 87,2 \% un specifiskums 92,3\% (Son SM, 2015). Sharma ar kolēgiem arī analizējis CEA pleiras punktātā. Pêtījumā ar 30 plaušu vēža pacientiem ar MPE un 18 pacientiem ar tuberkulozu pleirītu, seruma CEA jutība pie robežvērtības 4,8 ng/ml bija 78,3\%, bet pleiras punktāta CEA jutība - 82,6 \% gadījumu (Sharma et al., 2015). Pētījumā ar 601 MPE un 595 citas etiologijas pleiras šķidrumu tika noteikts CEA pleiras punktātā un pie robežvērtības 0,69 ng/ml jutība bija $69 \%$, bet specifiskums - $82 \%$ (Li et al., 2015). Bunjhoo ar kolēgiem analizēja 28 MPE un 28 malignus pleiras eksudātus un konstatēja, ka CEA jutība punktātā pie robežvērtības 3,48 ng/ml bija $75 \%$, bet specifiskums - $86 \%$ (Bunjhoo H. et al., 2012). Pēc mūsu datiem pie augstākas robežvērtības $(\geq 6,23)$ jutība bija ievērojami zemāka $(50,7 \%)$, bet specifiskums bija līdzīgs - 94,8 \%. Iespējams, ka šīs atšķkirības skaidrojamas ar to, ka mūsu pētījumā bija mazāks pacientu skaits.

Gan CEA, gan arī CA 125 pleiras punktātā un serumā tika noteikti 95 pacientiem ar MPE un 35 pacientiem ar tuberkulozu pleirītu. CEA vislielākais zemlīknes laukums, jutība un specifiskums bija punktātā pie robežvērtības 3,35 ng/ml (attiecīgi 0,86, $75 \%$ un 94 \%), arī CA 125 vislabākie rezultāti bija punktātā pie robežvērtības $644 \mathrm{U} / \mathrm{mL}$ - attiecīgi 0,78;61 \% un $83 \%$ (Gu et al., 2015). CEA un CA 125 pleiras punktātā noteica arī Antonangelo ar kolēgiem 114 
MPE un 42 tuberkuloza pleirīta pacientiem. CEA pie robežvērtības 5,2 ng/ml bija $65 \%$ jutība un $97,5 \%$ specifiskums, bet CA 125 pie robežvērtības $345,65 \mathrm{U} / \mathrm{mL}-68 \%$ jutība un $83 \%$ specifiskums (Antonangelo et al., 2015). Līdzīgi mūsu pētījumā punktātā abu marķieru jutība un specifiskums bija visaugstākie, bet robežvērtība, pie kuras bija visaugstākā jutība un specifiskums (attiecīgi 53,7 \% un 96,1 \%), bija ievērojami augstāka - 1644 U/ml.

Šajos pētîjumos ar dažādu pacientu skaitu galvenokārt tika analizēts CEA punktātā paralēli citiem marķieriem, tikai vienā pētījumā analizēts CA 125 un CEA gan serumā, gan punktātā, kā arī punktāta/seruma attiecība. Visos analizētajos pētījumos abu marķieru robežvērtība punktātā labākajai testa jutîbai un specifiskumam bija zemāka kā mūsu pētījumā: CEA 2,9-8,0 ng/ml (mūsu rezultātos 6,23 ng/ml), CA 125 mediānas bija 345-644 U/mL (mūsu pētījumā - $1644 \mathrm{U} / \mathrm{mL}$ ), arī jutība pēc mūsu datiem bija zemāka visiem rādītājiem, bet specifiskums - līdzīgs. Šajos pētījumos konstatēts, ka zemlīknes laukums CEA punktātā ir 0,74-0,92 (pēc mūsu datiem - 0,72), bet CA 125 punktātā - 0,78-0,85 (pēc mūsu datiem - 0,75). Zemlīknes laukums CEA serumā-0,79 (pēc mūsu datiem - 0,57), bet CA 125 serumā - 0,78-0,85 (pēc mūsu datiem - 0,706), kas kopumā ir salīdzināmi rādītāji.

Mūsu aprēḳinos vislielākais zemlīknes laukums bija CA 125 līmenim punktātā $(0,751)$ nevis serumā $(0,706)$ vai attiecībai punktāts / serums $(0,606)$, kas liek domāt par CA 125 lokālu sintēzi gan bojātās mezotēlija šūnās, gan ar̄̄ malignās šūnās. Ca 125 augstā pleiras punktāta / seruma attiecība $(\geq 10,61)$ maligniem eksudātiem salīdzinot ar citas etiolog̣ijas šḳidrumu pleiras dobumā varētu liecināt par ierobežotu sistēmisku difūziju.

Zemlīknes laukums CEA līdzịgi kā CA 125 vislielākais bija pleiras punktātā - 0,720, bet, atšķirībā no CA 125, arī punktāta / seruma attiecībai bija salīdzinoši liels AUC - 0,715, kas arī varētu liecināt vairāk par lokālu produkciju nekā sistēmisku difūziju.

Pēc mūsu datiem, abiem rādītājiem gan punktātā, gan serumā, gan arī punktāta / seruma attiecībai vislielākā jutība bija uz 25. percentiles, bet visaugstākais specifiskums - uz 75. percentiles.

Retrospektīvā pētījumā ar 326 pacientiem ar dažādas etiologijas pleiras šķidrumiem (tuberkulozs pleirīts, MPE, parapneimonisks pleirīts, kardiāls hidrotorakss un hepatisks hidrotorakss) tka noteikts CA 125 līmenis pleiras punktātā. Tuberkuloza pleirītā mediānais CA 125 līmenis bija 688,4 U/ml; MPE - 1325,7 U/ml; parapneimoniskam pleirītam - 502,4 U/ml; kardiālam hidrotoraksam - 498,02 U/ml un hepātiskam hidrotoraksam - 585,6 U/ml. MPE CA 125 līmenis bija statistiski ticami augstāks kā pārējās grupās. Sīkāk analizējot MPE grupu adenkokarcinomas gadījumā vidējais CA 125 līmenis bija 1624,6; plakanšūnu vēzim - 1189,1; krūts dziedzera vēzim - 502,5 U/1, nezināmas lokalizācijas vēzim - 1207,8 U/ml. Statistiski 
ticamas atšķirības starp dažādu lokalizāciju audzējiem CA 125 līmen̄i netika konstatētas (Choi et al., 2013). Mūsu pētījuma rezultāti ir ḷoti līdzīgi šī pētījuma rezultātiem - mediānais CA 125 līmenis MPE $1644 \mathrm{U} / \mathrm{ml}$; parapneimoniskam pleirītam - $412 \mathrm{U} / \mathrm{ml}$, bet kardiālam hidrotoraksam - $686 \mathrm{U} / \mathrm{ml}$.

Nguyen ar kolēǵiem veica 49 pētījumu metaanalīzi. Tika iekḷauti 37 gadījumu kontroles pētījumi, no tiem 33 pētījumi bija prospektīvi, bet 25 pētījumos tika ņemti pleiras šķidruma paraugi no secīgi stacionētiem pacientiem. Vidējais pacientu skaits pētījumā bija 140 pacienti (25-654). Visos pētījumos MPE tika apstiprināts ar pozitīvu citologiiju, pleiras biopsiju vai autopsiju. Apvienotā jutība un specifiskums MPE diagnostikā attiecīgi bija: CEA 54,9 un 96,2 \%; CA 15-3 50,7 un 98,3 \%; CA 19-9 37 ,6 un 98,0 \%; CA 125 - 57,5 un 92,8 \%; CYFRA 62,5 un 93,2 \%. salīdzinot ar šo metaanalīzi, aprēḳinātās vērtības ir ḷoti līdzīgas - CEA jutība pie mediānās vērtības bija 50,7, bet specifiskums - 94,8, savukārt CA 125 attiecīgi - 53,7 \% un 96,1 \%. Autori secināja, ka, kaut gan visiem marḳieriem ir augsts specifiskums, tomēr zemā jutîba ierobežo šo marḳieru rutīnas lietošanu klīniskajā praksē. Marḳieru kombinēšana uzlabo jutību. Autori secināja arī, ka marķieru koncentrācija pleiras punktātā tiek mērīta bieži, bet pētījumu par marḳieru koncentrāciju serumā ir mazāk (Nguyen et al., 2015). Mūsu pētījumā tika noteikti arī marḳieru līmeṇi serumā, tomēr līmeṇi punktātā visos gadījumos izrādījas augstāki. Kombinējot labākos diagnostiskos rādītājus rādītājus - CEA pleiras punktāta/seruma attiecību un CA 125 līmeni punktātā, jutība bija 56,4\%, specifiskums - 93,3 \%, kas nav būtiski labāk kā tikai CEA punktāta/seruma attiecība vai CA 125 līmenis punktātā.

Retrospektīvi analizēti dati par 2115 pacientiem (85 gadus veci un vecāki) - šiem hospitalizētajiem pacientiem tika klīniski un ehokardiogrāfiski apstiprināta sirds mazspēja, serumā noteikti audzēju marķieri, ts. k. CA 125 un NT-proBNP un atzīmēta perifēras tūskas un transudātu esamība, pacienti tika apsekoti pēc 180 dienām. CA 125 un NT-proBNP līmenis statistiski ticami pieauga, palielinoties sirds mazspejas pakāpei, turklāt tika konstatēta lineāra korelācija starp abiem šiem marķieriem $(\mathrm{r}=5103, \mathrm{p}=0,05)$. CA 125 vidējais līmenis serumā bija statiski ticami augstāks pacientiem ar transudātu pleiras dobumā salīdzinājumā ar pacientiem bez transudāta $(108,5 \mathrm{U} / \mathrm{L}$ vs $12,1 \mathrm{U} / \mathrm{L})$ un pacientiem ar perifēru tūsku salīdzinājumā ar pacientiem bez perifēras tūskas (78,4 U/L vs 11,9 U/L). 180 dienu laikā 305 pacientiem tika konstatēta kardiāla nāve, bet 461 pacients tika atkārtoti hospitalizēts. Šiem pacientiem CA 125 bija statistiski ticami augstāks nekā pārējiem pacientiem - 78,2 U/L vs 11,7 U/L. Kaplāna - Maiera līknes demonstrēja būtisku atšḳirību pacientiem ar normālu un pacientiem ar paaugstinātu CA 125 līmeni serumā. Par pārējiem audzēja marḳieriem šādus statistiski ticamus datus nekonstatēja. Izskaidrojumu šādiem rezultātiem pētnieki pagaidām 
nevar formulēt (Ma et al., 2013). Mūsu aprēḳini gan liecina, ka CA 125 līmenis MPE statistiski ticami atšķiras no paprapneimonisku pleirītu un kardiālu hidrotoraksu līmeņa gan punktātā, gan serumā, bet nav statistiski ticamas atšķirības starp CA 125 līmeni kardiāla hidrotoraksa un parapneimoniska pleirīta grupās ne punktātā $(\mathrm{p}=0,850)$, nedz arī serumā $(\mathrm{p}=0,694)$, bet mūsu gadījumā pacientiem sirds mazspēja netika apstiprināta ehokardiogrāfiski.

Pètījumā ar 134 pacientiem, no tiem 90 MPE, tika salīdzināta CEA līmeņa pleiras punktātā un serumā un pleiras punktāta citoloğijas jutība un specifiskums. CEA jutība (robežvērtība $5 \mathrm{ng} / \mathrm{ml}$ ) pleiras punktātā nesīkšūnu vēzim bija 97,3 \%, bet specifiskums 97,7 \%, bet pleiras citologijai - attiecīgi 64,9 \% un 97,7 \%, apvienojot abas metodes, jutība bija $100 \%$; savukārt citas etioloǵijas MPE CEA pleiras punktātā jutība bija 74,6 \%, specifiskums - 97,7 \%, bet pleiras punktāta citolog̣ijai - 53,5\% un 97,7 \%. Tie paši autori izanalizējuši 39 autoru pētījumus (pacientu skaits 77-1137) no 1978. līdz 2015. gadam, kuros aprēḳināta CEA jutība un specifiskums. Šajos pētījumos robežvērtība bija no 1,4-5 ng/ml, jutība - no 27 līdz 87,2 \%, bet specifiskums - 77,0-98,6 \%. Autori secinājuši, ka CEA līmenis serumā nav izmantojams MPE diagnostikā, bet CEA līmenis apvienojumā ar pleiras dobuma citologiju ir labs diagnostisks rādītājs, lai lemtu par indikācijām tālākām invazīvākām izmeklēšanas metodēm (Tozzoli et al., 2016). Pēc mūsu datiem, pacientiem ar pozitīvu citoloǵiju CEA līmenis punktātā statistiski būtiski neatšḳīrās no CEA līmeṇa pacientiem, kuriem citoloǵija bija negatīva - visos gadījumos $\mathrm{p}>0,05$.

\subsubsection{BNP}

BNP veidojas miokarda šūnās, paaugstinoties kambaru pild̄̄šanās spiedienam, no prehormona proBNP, tam sadaloties aktīvā BNP un inertā NT-proBNP (NT $-N$ terminal) ekvimolārā koncentrācijāa, kas nokḷūst asinsritē. BNP un Pr-NT-BNP uzskata par sirds mazspējas marḳieriem. Transudātu un eksudātu diferencēšana ir svarīga, jo no pleiras šķidruma veida ir atkarīga tālāka pacienta aprūpes stratēg̣ija un taktika, bet Laita kritēriji ir viltus pozitīvi apmēram 25\% transudātu, tos maldinoši klasificējot kā eksudātus.

Marinho un kolēgi 2011. gadā salīdzinājuši kardiālu hidrotoraksu (34 pacienti) ar hepātisku hidrotoraksu (10 pacienti), l,aundabīgu eksudātu (21 pacients) un tuberkulozu pleirītu (12 pacienti). Konstatēts, ka robežvērtības sirds mazspējas diagnostikā bija 132 pg/ml seruma BNP līmenim (jutība 97,1 \%, specifiskums 97,4 \%) un 127 pg/ml pleiras škidrumam (jutība 97,1 \%, specifiskums 87,8 \%), tāpēc secināts, ka BNP līmenis gan serumā, gan pleiras šḳidrumā ir noderīgs marķieris sirds mazspējas diagnostikā (Marinho et al., 2011). 
Mūsu pētījumā jutība gan puntkātā, gan serumā bija ievērojami mazāka (abos subtrātos 50 \%), bet specifiskums līdzīgs - 97,3 pleiras punktātā un 95,9 \% serumā, arī robežvērtības bija būtiski augstākas - 1097 pg/ml punktātam un 1631 pg/ml serumam.

Desmit pētījumu metaanalīzē, kurā tika iekḷauti kopumā 1120 pacienti, tika konstatēts, ka kardiālu hidrotoraksu identificēšanā NT-proBNP kopējā jutība un specifiskums ir $94 \%$, pozitīvā paredzes vērtība 15,2 un negatīvā paredzes vērtība - 0,06. Pēc autoru datiem izriet, ka vairāk nekā $85 \%$ pacientu ar sirds mazspēju, kuru pleiras dobuma šķidrums pēc Laita kritērijiem atbilda eksudātam, bija augsta NT-proBNP koncentrācija. Autori secināja, ka BNP diagnostiskā vērtība ir zemāka nekā NT-proBNP diagnostiskā vērtība, tāpēc tika ieteikts izmantot NT-proBNP (Porcel et al., 2011). 2010. gadā Long salīizināja BNP un NT-proBNP līmeņus pleiras šḳidrumā 80 pacientiem (20 hroniskas sirds mazspējas pacientiem, 20 pacientiem pēc aortokoronārās šuntēšanas, 20 pacientiem ar l̦aundabīgu eksudātu un 20 pacientiem ar pneimoniju. Kolēǵis konstatēja, ka abu minēto marḳieru korelācija bija 0,572\% (Spīrmena koeficients), $\mathrm{p}<0,001$. Tika secināts, ka, kaut arī korelācija ir statistiski ticama, tomēr NT-proBNP ir labāks marķieris kardiālu hidrotoraksu diagnostikā (Long, 2010). Mūsu pētījuma uzdevums nebija analizēt NT-proBNP līmeni, tomēr pārliecinoša diagnostiskā vērtība ir arī BNP testam.

Kolditz un kolēg̣i apsekojuši 93 pacientus, $73 \%$ no tiem ar kardiālu hidrotoraksu. Nosakot NT-proBNP līmeni pleiras punktātā un serumā, konstatēts, ka kardiāla hidrotoraksa gadījumos tas ir statistiski ticami paaugstināts, turklāt šî marķiera līmenis serumā un pleiras punktātā cieši korelēja - Spīrmana korelācijas koeficients bija 0,963, p < 0,001 (Kolditz et al., 2006). Mūsu pētījumā, analizējot ROC līknes, konstatēts, ka zemlīknes laukums gan pleiras punktātam, gan serumam ir 0,921, kas norāda uz augstu diagnostiskās metodes jutību un specifiskumu abos substrātos, tāpēc, iespējams, BNP tests asins serumā ir pietiekams, lai diagnosticētu vai izslēgtu kardiālas etiolog̣ijas transudātu pleiras dobumā, līdz ar to pasargājot pacientu no nevajadzīgas invazīvas iejaukšanās un optimizējot izmeklējumu izmaksas.

\subsubsection{PAI-1}

Pētījumu, kas analizētu PAI-1 nozīmi pleiras punktātā, ir maz. 1995. gadā 10 pacientiem ar empiēmu, 9 - ar tuberkulozu pleirītu, 31 - ar MPE un 3 ar neskaidras etioloǵijas šķidrumu pleiras dobumā tika noteikti PAI-1 un D dimēri gan plazmā, gan pleiras punktātā. Tika konstatēts, ka gan D dimēru, gan PAI-1 līmenis pleiras punktātā ir augstāks nekā plazmā. Pacientiem ar tuberkulozi un empiēmu PAI-1 līmenis bija augstāks nekā pacientiem ar kardiālu transudātu vai MPE (Philip-Joët et al., 1995), kas pilnībā atbilst mūsu datiem, kuros pierādīts, 
ka PAI-1 līmenis parapneimoniskos eksudātos ir statistiski ticami augstāks nekā malignos eksudātos un kardiālos transudātos.

Pētījumā ar 19 tuberkuloza pleirīta, 29 MPE, 30 parapneimoniska pleirīta pacientiem pleiras punktātā papildus citiem marķieriem tika noteikti arī PAI-1. Atkarībā no šķidruma izvietojuma pleiras dobumā pacienti tika iedalīti divās grupās - norobežots (42 pacienti) un brīvs šķidrums pleiras dobumā (36 pacienti). Grupā ar norobežotu šķidrumu pleiras dobumā bija ievērojami augstāks PAI-1 līmenis - 114,9 vs 94,1 pg/ml; p = 0,019. Acīmredzot paaugstināts PAI-1 norāda uz samazinātu fibrinolīzi norobežotos šķidrumos (Chung et al., 2005). Citā pêtījumā 64 parapneimoniska pleirīta pacienti tika sadalīti divās grupās - nekomlicēts (26 pacienti) un komplicēts - norobežots (38 pacienti) parapneimonisks pleirīts. Nekomplicētā parapneimoniskā pleirītā PAI-1 līmenis bijs 43 pg/ml, bet komplicētā - $104 \mathrm{pg} / \mathrm{ml}$ ( $\mathrm{p}<0,01$ ), kas arī norāda uz samazinātu fibrinolītisko aktivitāti pleiras dobumā fibrīna septu veidošanās laikā (Chung et al., 2013). Mūsu gadījumā pacienti netika dalīti atkarībā no šķidruma norobežošanās pleiras dobumā, bet pacientiem ar parapneimonisku pleirītu, kuriem bija raksturīgāka fibrīna veidošanās un šķidruma norobežošanās, mediānais PAI-1 līmenis bija statistiski ticami augstāks - $291 \mathrm{ng} / \mathrm{ml}, \mathrm{p}<0,001$.

Kopumā parapneimoniskiem pleirītiem raksturīga fibrīna veidošanās un šķidrumam ir tendence norobežoties, lokalizējot procesu. Līdz šim veiktie pētījumi parādījuši, ka iekaisīga rakstura šķidrumos tiešām ir paaugstināts PAI-1 līmenis, kas sekmē fibrinolīzes inhibīciju un veicina fibrīna veidošanos (Idell et al., 1991; Lin et al., 2005). Tas nozīmēe, ka, iespējams, PAI1 pastiprinātu veidošanos ietekmē iekaisuma process. Arī mūsu pētījums parādīja, ka parapneimoniskos eksudātos PAI-1 līmenis ir būtiski augstāks kā malignos eksudātos.

Maligniem pleiras eksudātiem nav tendence norobežoties, kas liecina par to, ka tajos fibrīns parasti neveidojas vai veidojas maz, kas varētu būt saistīts ar vidēju PAI-1 aktivitāti (Lin et al., 2005; Lu et al, 2008). Mūsu iegūtie dati liecina par ievērojami zemāku PAI-1 līmeni malignos pleiras eksudātos salīdzinot ar parapneimoniskiem eksudātiem - $188 \mathrm{ng} / \mathrm{ml}$ un 291 ng/ml, p < 0,001. Pēc mūsu domām, PAI-1 vidēji augstais līmenis MPE nesekmē fibrīna veidošanos un šķidruma norobežošanos līdzīgi kā parapneimoniskiem pleirītiem, bet gan veicina patologiiskā procesa izplatīšanos. Atklāts paliek jautājums par to, kas inhibē PAI-1 veidošanos MPE un kā to varētu novērst. Tā kā MPE paliatīvās ārstēšanas pamatā ir procesa norobežošana ar jatrogēni izraisītu fibrīna izgulsnēšanos, tad, iespējams, atbilde uz šo jautājumu varētu uzlabot MPE ārstēšanas taktiku. 
Pēc mūsu datiem, arī serumā PAI-1 līmenis bija statistiski ticami augstāks parapneimoniskiem pleirītiem nekā MPE un kardiāliem transudātiem, kas liecina par šî fibrīna inhibitora sistēmisku darbību.

\subsection{Pētījuma rezultātus ietekmējoši faktori}

Pētījuma rezultātus un to interpretāciju ir ietekmējuši vairāki faktori - retrospektīvi analizējot pacientu medicīniskās kartes, varējām spriest tikai pēc ārstējošo ārstu ierakstiem un izmeklējumu rezultātiem, kas atrodami vēsturē, līdz ar to datu kvalitāte zināmā mērā bija atkarīga no medicīniskās dokumentācijas noformēšanas kvalitātes. Prospektīvajā daḷā tika analizēti tikai pacienti, kas nokḷuva Pulmonoloǵijas nodaḷā, līdz ar to pētījumā netika iekḷauti pacienti ar citu etiolog̣iju šḳidrumiem pleiras dobumā (hepatisks hidrotorakss, hidrotorakss hiperhidratācijas vai nefrotiskā sindroma dēl, pleirīti vēdera dobuma patoloǵijas dēḷ, PATE pleirīti u.c.).

Laboratoro rādītāju interpretāciju, iespējams, varēja ietekmēt paraugu nogādāšanas laboratorijā laiks un to analizēšanas ātrums, kas nebija no mums atkarīgs.

Rezultātu interpretāciju ietekmē arī relatīvi nelielā prospektīvi pētīto pacientu grupa, kā arī tas, ka nebija iespējas pacientiem veikt torakoskopijiu un apstiprināt MPE diagnozi arī histolog̣iski. 


\section{SECINĀJUMI}

1. SIA RAKUS stacionāra "Gaiḷezers" iekšķ̄īgo slimību profila nodaḷās visbiežākā pleiras šḳidruma etiologija bija sirds mazspēja, bet plaušu slimību profila nodaḷā - maligns pleiras eksudāts.

2. Pacientu ar šķidrumu pleiras dobumā hospitālā mirstība ir trīs reizes augstāka nekā visiem stacionāra pacientiem kopumā.

3. CA 125 līmeni pleiras punktātā var izmantot kā vērtīgu papildus diagnostisku marḳieri malignu pleiras eksudātu diferencēšanā no citu etioloǵiju šķidrumiem pleiras dobumā.

4. Plazminogēna aktivatora inhibotora 1 līmenis malignos pleiras eksudāros bija statistiski ticami zemāks nekā parapneimonisku pleirītu gadījumos, kas liecina par procesa izplatības tendenci ḷaundabīgu slimību gadījumos, tāpēc būtu vērtīgi tālāki fibrinolītiskās sistēmas aktivitātes pētījumi malignos pleiras eksudātos.

5. Kardiāla hidrotoraksa diferencēšanai informatīvs marķieris ir BNP asins serumā, BNP pleiras punktātā papildus diagnostisku informāciju nesniedz.

6. SIA RAKUS stacionāra “Gaiḷezers” iekšḳ̄ịo slimību profila nodạ̣ās pleiras šḳidrumu izmeklēšanas metodes analizētajā periodā bija nepietiekamas salīdzinot ar vadlīnijās un medicīnas literatūrā rekomendētām metodēm. 


\section{PRAKTISKĀS REKOMENDĀCIJAS}

Lai uzlabotu pleiras dobuma šķidruma diagnostiku, diferenciāldiagnostiku un atvieglotu savlaicīgu un maksimāli efektīvu ārstēšanu, nepieciešams:

1. Visiem pacientiem, kuriem klīniskā aina neliecina par patologiju, kura komplicējas ar transudātu pleiras dobumā (dekompensēta sirds mazspēja, dekompensēta aknu mazspēja, hroniska nieru slimība) un kuriem ir šķidrums pleiras dobumā patoloǵiskā daudzumā, nepieciešama pleiras dobuma punkcija ar pirmspunkcijas ultrasonoskopiju.

2. Minimālais laboratoro izmeklējumu daudzums:

1) LDH un olbaltumvielu noteikšana pleiras punktātā un serumā;

2) citologisiskā pleiras punktāta izmeklēšana.

3. Lai pierādītu kardiālu transudātu, jānosaka BNP vai NT-pro-BNP asins serumā.

4. Ja ir aizdomas par MPE, bet citoloǵija ir negatīva un nav pieejama torakoskopija, pleiras punktātā var noteikt CA 125. 


\section{IZMANTOTĀ LITERATŪRA}

1. Agostoni, E., Zocchi, L., 2007. Pleural liquid and its exchanges. Respiratory Physiology \& Neurobiology. 159(3). Iegūts no: https://www-clinicalkey-com.db.rsu.lv/\#!/content/journal/1-s2.0S1569904807002030 (sk. 07.08.2016.).

2. Akturk, U. A., Ernam, D., Akbay, M. O. et al., 2016. Role of the Neutrophil-Lymphocyte Ratio in the Differential Diagnosis of Exudative Pleural Effusion. Clinics (Sao Paulo). Iegūts no: https://www.ncbi.nlm.nih.gov/pmc/articles/PMC5054976/ (sk. 04.02.2017.)

3. Albertine, K. H., Wiener-Kronish, J. P., Bastacky, J. et al., 1991. No evidence for mesothelial cell contact across the costal pleural space of sheep. J Appl Physiol. 70: 123-134.

4. Albertine, K. H., Wiener-Kronish, J. P., Roos, P.J. et al., 1982. Structure, blood supply, and lymphatic vessels of the sheep's visceral pleura. Am J Anat. 165: 277-294.

5. Albertine, K. H., Wiener-Kronish, J. P., Staub, N. C., 1984. The structure of the parietal pleura and its relationship to pleural liquid dynamics in sheep. Anat Rec. 208: 401-409.

6. Alemán, C., Porcel, J. M., Alegre, J. et al., 2015. Intrapleural Fibrinolysis with Urokinase Versus Alteplase in Complicated Parapneumonic Pleural Effusions and Empyemas: A Prospective Randomized Study. Lung. Iegūts no: http://link.springer.com/article/10.1007\%2Fs00408-0159807-6 (sk. 28.08.2016.).

7. Altman, D. G., 1997. Practical Statistics for Medical Research. London, Chapman \& Hall.

8. Andreasen, P. A., 2007. PAI-1 - a potential therapeutic target in cacer. Curr Drug Targets. 8(9): 1030-1041.

9. Anevlavis, S., Kouliatsis, G., Sotiriou, I. et al., 2014. Prognostic factors in patients presenting with pleural effusion revealing malignancy. Respiration. Iegūts no: ttp://search.proquest.com.db.rsu.lv /docview/1531631902?accountid=32932 (sk.05.02.2017)

10. Antonangelo, L., Sales, R. K., Corá, A. P. et al., 2015. Pleural fluid tumour markers in malignant pleural effusion with inconclusive cytologic results. Curr Oncol. Iegūts no: https://www.ncbi.nlm.nih.gov/pmc/articles/PMC4608406/ (sk. 26.08.2016.).

11. Antony, V. B., Loddenkemper, R., Astoul, P. et al., 2001. Management of malignant pleural effusions. Eur Respir J. Iegūts no: http://erj.ersjournals.com/content/18/2/402.long\#T1 (sk. 09.08.2016.).

12. Antunes, G., Neville, E., Duffy, J. et al., 2003. Pleural Diseases Group, Standards of Care Committee, British Thoracic Society. BTS guidelines for the management of malignant pleural effusions. Thorax. Iegūts no: https://www.ncbi.nlm.nih.gov/pmc/articles/PMC1766015/ (sk. 12.08.2016.).

13. Ault, M. J., Rosen, B. T., Scher, J. et al., 2015. Thoracentesis outcomes: a 12-year experience. Thorax. 70(2): 127-132.

14. Balsara, R. D., Ploplis, V. A., 2008. Plasminogen activator inhibitor-1: the double-edged sword in apoptosis. Thromb Haemost. Iegūts no: https://www.ncbi.nlm.nih.gov/pmc/articles/PMC3674867/ (sk. 27.08.2016).

15. Balsara, R. D., Ploplis, V. A., 2008. Plasminogen activator inhibitor-1: the double-edged sword in apoptosis. Thromb Haemost. Iegūts no: https://www.ncbi.nlm.nih.gov/pmc/articles/PMC3674867/ (sk. 27.08.2016.).

16. Barnes, T. W., Morgenthaler, T. I., Olson, E. J. et al., 2005. Sonographically guided thoracentesis and rate of pneumothorax. J Clin Ultrasound. 33(9): 442-446.

17. Bhatnagar, R., Maskell, N., 2015. The modern diagnosis and management of pleural effusions. BMJ. Iegūts no: http://www.bmj.com.db.rsu.lv/content/351/bmj.h4520 (sk. 17.08.2016.). 
18. Bielsa. S, Porcel. J. M., Castellote, J., 2012. Solving the Light's criteria misclassification rate of cardiac and hepatic transudates. Respirology. 17(4): 721-726.

19. Bielsa, S., Salud, A., Martínez, M. et al., 2008. Prognostic significance of pleural fluid data in patients with malignant effusion. Eur J Intern Med. 19(5): 334-339.

20. Broaddus, V. C., Light, R. W., 2016. Pleural effusion. No: Broaddus, V. C., Mason, R. J., Ernst, J. D. et al. Murray and Nadels Textbook of Respiratory Medicine. $6^{\text {th }}$ ed. Elsevier. Iegūts no: https://www-clinicalkey-com.db.rsu.lv/\#!/content/book/3-s2.0-B9781455733835000798 (sk. 06.08.2016.)

21. Brunner-La Rocca, H. P., Kaye, D. M., Woods, R. L. et al., 2001. Effects of intravenous brain natriuretic peptide on regional sympathetic activity in patients with chronic heart failure as compared with healthy control subjects. J Am Coll Cardiol. 37(5): 1221.

22. Bunjhoo, H., Wang, Z. Y., Chen, H. L., 2012. Diagnostic value of interleukin 21 and carcinoembryonic antigen levels in malignant pleural effusions. Asian Pac J Cancer Prev. Iegūts no: http://journal.waocp.org/article_26692_aaf0b49d3b2cc7097fbca0a5e6c4fe85.pdf (sk. 04.02.2017.)

23. Carty, R. P., Pincus, M. R., 2016. Sarafraz-Yazdi, E. Clinical Enzymology. No: McPherson R., Pincus, M. R. Henry's Clinical Diagnosis and Management by Labaratory Methods. $23^{\text {rd }}$ ed. Elsevier, 286-287.

24. Chen, K. C., Chen, H. Y., Lin, J. W. et al., 2014. Acute thoracic empyema: clinical characteristics and outcome analysis of video-assisted thoracoscopic surgery. J Formos Med Assoc. Iegūts no: http://www.sciencedirect.com/science/article/pii/S0929664614000059?np=y\&npKey=91f0d6d17 e9c373792d7962a20737799df2f825dc2a3077aa5f5c4274b7b6376 (sk. 31.01.2017.).

25. Cheng, D., Rodriguez, R. M., Perkett, E. A. et al., 1999. Vasular endothelial growth factor in pleural fluid. Chest. 116: 760-765.

26. Choi, W. I., Qama, D., Lee, M. Y. et al., 2013. Pleural cancer antigen-125 levels in benign and malignant pleural effusions. Int J Tuberc Lung Dis. Iegūts no:

$\mathrm{http} / / /$ docserver.ingentaconnect.com/deliver/connect/iuatld/10273719/v17n5/s23.pdf?expires $=147$ $2295620 \& \mathrm{id}=88480205 \&$ titleid $=3764 \&$ accname $=$ GGues + User \&checksum $=4 \mathrm{EDAA} 1630 \mathrm{E} 52 \mathrm{CF}$ 24C7F2F5A0B3EBCDB4 (sk. 27.08.2016.).

27. Chung, C. L., Chen, C. H., Sheu, J. R. et al., 2005. Proinflammatory cytokines, transforming growth factor-beta1, and fibrinolytic enzymes in loculated and free-flowing pleural exudates. Chest. Iegūts no: http://www.sciencedirect.com.db.rsu.lv/science/article/pii/S00 12369215500012 (sk. 27.08.2016.).

28. Chung, C. L., Hsiao, S. H., Hsiao, G. et al., 2013. Clinical importance of angiogenic cytokines, fibrinolytic activity and effusion size in parapneumonic effusions. PLoS One. Iegūts no: https://www.ncbi.nlm.nih.gov/pmc/articles/PMC3538784/\#pone.0053169-Cameron1 (sk. 28.08.2016.).

29. Chung, Ch. L., Chen, Y. C., Chang, S. C., 2003. Effect of repeated thoracocenteses on fluid characteristics, cytokines and fibrinolytic activity in malignant pleural effusion. Chest. 123: 11881195.

30. Clive, A. O., Kahan, B. C., Hooper, C. E. et al., 2014. Predicting survival in malignant pleural effusion: development and validation of the LENT prognostic score. Thorax. Iegūts no: https://www.ncbi.nlm.nih.gov/pmc/articles/PMC4251306/ (sk. 27.08.2006.).

31. Daniil, Z. D., Zintzaras, E., Kiropoulos, T. et al., 2007. Discrimination of exudative pleural effusion based of multiple biological parameters. Eur Resp J. 30: 957-964.

32. Dara, M., Dadu, A., Kremer, K et al., 2013. Epidemiology of tuberculosis in WHO European Region and public health response. Eur Spine J. 22(4) 549-555. 
33. Davies, H. E., Davies, R.J., Davies, C. W., 2010. BTS Pleural Disease Guideline Group.Management of pleural infection in adults: British Thoracic Society Pleural Disease Guideline 2010. Thorax. Iegūts no: https://www.brit-thoracic.org.uk/document-library/clinicalinformation/pleural-disease/pleural-disease-guidelines-2010/pleural-disease-guideline/ (sk. 31.01.2017.).

34. Dawson, B., Trapp, R. G., 2001. Basic \& Clinical Biostatistics. New York, Lange Medical Books/McGraw-Hill.

35. Diem, S., Kasenda, B., Martin-Liberal, J. et al., 2015. Prognostic score for patients with advanced melanoma treated with ipilimumab. Eur $J$ Cancer. Iegūts no: http://www.ejcancer.com/article/S0959-8049(15)00853-9/fulltext (sk. 07.08.2016.).

36. Dresler, C. M., Olak, J., Herndon, J. E. et al., 2005. Cooperative Groups Cancer and Leukemia Group B; Eastern Cooperative Oncology Group; North Central Cooperative Oncology Group; Radiation Therapy Oncology Group. Phase III intergroup study of talc poudrage vs talc slurry sclerosis for malignant pleural effusion. Chest. Iegūts no: https://www.ncbi.nlm.nih.gov/pmc/articles/PMC4644736/ (sk. 28.08.2016.).

37. Duffy, M. J., O'Donovan, N., McDermott, E. et al., 2016. Validated biomarkers: The key to precision treatment in patients with breast cancer. Breast. ttp://www.sciencedirect.com.db.rsu.1 v/science/article/pii/S0960977616300960 (sk. 27.08.2016.).

38. Eljuga, D., Razumovic, J. J., Bulic, K. et al., 2011. Prognostic importance of PAI-1 in node negative breast cancer patients--results after 10years of follow up. Pathol Res Pract. Iegūts no: http://www.sciencedirect.com.db.rsu.lv/science/article/pii/S0344033811000344 (sk. 27.08.2016.).

39. Fafliora, E., Hatzoglou, C., Gourgoulianis, K. I., Zarogiannis, S. G., 2016. Systematic review and meta-analysis of vascular endothelial growth factor as a biomarker for malignant pleural effusions. Physiol Rep. Iegūts no: https://www.ncbi.nlm.nih.gov/pmc/articles/PMC5210377/ (sk. 31.01.2017.).

40. Faloppi, L., Bianconi, M., Giampieri, R. et al., 2015. The value of lactate dehydrogenase serum levels as a prognostic and predictive factor for advanced pancreatic cancer patients receiving sorafenib. Oncotarget. Iegūts no: http://www.ncbi.nlm.nih.gov/pmc/articles/PMC47415 11/ (sk. 07.08.2016.).

41. Fashoyin-Aje, L. A., Brahmer, J. R., 2014. Malignant effusions. No: Niederhuber, J. E., Armitage, J. O., Doroshow, J. H et al. Abeloff's clinical oncology. $5^{\text {th }}$ ed. Saunders. Iegūts no: https://wwwclinicalkey-com.db.rsu.lv/\#!/content/book/3-s2.0-B9781455728657000540 (sk. 09.08.2016.).

42. Feller-Kopman, D. J., Reddy, C. B., DeCamp, M. M. et al., 2018. Management of Malignant Pleural Effusions. An Official ATS/STS/STR Clinical Practice Guideline. Am J Respir Crit Care Med. 198(7): 839-849.

43. Feng. M., Zhu. J., Liang. L. et al., 2016. Diagnostic value of tumor markers for lung adenocarcinoma-associated malignant pleural effusion: a validation study and meta-analysis. Int $J$ Clin Oncol. Iegūts no: http://link.springer.com/article/10.1007\%2Fs10147-016-1073-y (sk. 04.02.2017.).

44. Fetsch, P. A., Abati, A., 2001. Immunocytochemistry in effusion cytology: a contemporary review. Cancer. 93: 293-308.

45. Fiala, O., Pesek, M., Finek, J. et al., 2016. Change in Serum Lactate Dehydrogenase Is Associated with Outcome of Patients with Advanced-stage NSCLC Treated with Erlotinib. Anticancer Res. 36(5): 2459-2465.

46. Gibbons, S. M., Ahmed, F., 2015. Chylothorax diagnosis: can the clinical chemistry laboratory do more? Ann Clin Biochem. Iegūts no: http://acb.sagepub.com/content/52/1/173.long (sk. 18.08.2016.). 
47. Girdhard, A., Shujaat, A., Bajwa, A., 2012. Management of infectious processes of the pleural space: a review. Pulm Med. Iegūts no: https://www.ncbi.nlm.nih.gov/pmc/articles/PMC3317076/ (sk. 28.08.2016.).

48. Gu, Y., Zhai, K., Shi, H. Z., 2016. Clinical Value of Tumor Markers for Determining Cause of Pleural Effusion. Chin Med J (engl). Iegūts no: https://www.ncbi.nlm.nih.gov/pmc/articles/PM C4799566/ (sk. 04.02.2017.)

49. Harbeck, N., Schmitt, M., Meisner, C. et al., Chemo-N0 Study Group. 2013. Ten-year analysis of the prospective multicentre Chemo-N0 trial validates American Society of Clinical Oncology (ASCO)-recommended biomarkers uPA and PAI-1 for therapy decision making in node negative breast cancer patients. Eur J Cancer. Iegūts no: http://ac.els cdn.com.db. rsu.lv/S0959804913000452/1 s2.0 S0959804913000452 main.pdf?_tid=c0979b5e 6c9a-1e6- 0fa0000aacb361\&acdnat=1472332439_c909b85fb2724a076055f0c452931b72 (sk. 27.08.2016.).

50. Havelock, T., Teoh, R., Laws, D. et al., 2010. Pleural procedures and thoracic ultrasound: British Thoracic Society pleural disease guideline 2010. Iegūts no: http://thorax.bmj.com/content/ 65/Suppl_2/i61.full.pdf+html (sk. 09.08.2016.).

51. Heffner, J. E., Nietert, P. J., Barbieri, C., 2000. Pleural fluid $\mathrm{pH}$ as a predictor of survival for patients with malignant pleural effusions. Chest. Iegūts no: http://www.sciencedirect.com/scie nce/article/pii/S0012369215309338 (sk. 18.08.2016.).

52. Higgins, R. A., Kitchen, S., Olson, J. D., 2013. Hemostasis. No: Burtis, C. A., Ashwood, E. R., Brauns, D. E. Textbook of clinical chemistry and molecular diagnosticess. $5^{\text {th }}$ ed. Saunders. Iegūts no: https://www.clinicalkey.com.db.rsu.lv/\#!/content/book/3 s2.0 B9781416061 649000597? scrollTo=\%23hl0001787 (sk. 27.08.2016.).

53. Hirahata, M., Osaki, M., Kanda, Y. et al., 2016. PAI-1, a target gene of miR-143, regulates invasion and metastasis by upregulating MMP-13 expression of human osteosarcoma. Cancer Med. Iegūts no: https://www.ncbi.nlm.nih.gov/pmc/articles/PMC4864819/ (sk. 27.08.2016.)

54. Hooper, C., Lee, Y. C., Maskell, N., 2010. BTS Pleural Guideline Group. Investigation of a unilateral pleural effusion in adults: British Thoracic Society Pleural Disease Guideline 2010. Thorax. Iegūts no: https://www.brit-thoracic.org.uk/document-library/clinical-information/pleuraldisease/pleural-disease-guidelines-2010/pleural-disease-guideline/ (sk. 17.08.2016.).

55. Hopewell, P. C., Kato-Maeda, M., Ernst, J. D., 2016. Tuberculosis. No: Broaddus, V.C., Mason R. J., Ernst J. D. et al. Murray and Nadels Textbook of Respiratory Medicine. $6^{\text {th }}$ ed. Elsevier. Iegūts no: https://www-clinicalkey-com.db.rsu.lv/\#!/content/book/3-s2.0-B9781455733835000798 (sk. 06.08.2016.).

56. How, S. H., Liam, C. K., Jamalludin, A. R., et al., 2006. Serum cancer antigen 125 in patients with pleural effusions. Med J Malaysia. 61(5): 558-563. Iegūts no:

http://onlinelibrary.wiley.com/doi/10.1002/jcu.20163/pdf (sk. 09.08.2016.).

57. Huggins, J. T., Sahn, S. A., Doelken, P., 2011. Thoracenthesis. No: Vincent, J. L., Abraham, E., Kochanek, P. et al. Textbook of ciritical care. $3^{\text {rd }}$ ed. Saunders. Iegūts no: https://www-clinicalkeycom.db.rsu.lv/\#!/content/book/3-s2.0-B9781437713671002391 (sk. 08.08.2016.).

58. Husain, H., Nykin, D., Bui, N. Et al. 2017. Cell-Free DNA from Ascites and Pleural Effusions: Molecular Insights into Genomic Aberrations and Disease. Biology. Mol Cancer Ther. 16(5). Iegūts no: https://mct.aacrjournals.org/content/16/5/948.long (sk.03.05.2020).

59. Idell, S., Girard, W., Koenig, K. B., Mclarty, J., Fair, D. S., 1991. Abnormalities of pathways of fibrin turnover in the human pleural space. Am. Rev. Respir. Dis. 144: 187-194.

60. Iwanaga, Y., Nishi, I., Furuichi, S. et al., 2006. B-type natriuretic peptide strongly reflects diastolic wall stress in patients with chronic heart failure: comparison between systolic and diastolic heart failure. J Am Coll Cardiol. 47(4): 742.

61. Jain, S., Pincus, M. R., Bluth, M. H., 2016. Diagnosis and management of cancer using serologic and other body fluid markers. No: McPherson, R. A., Pincus, M. R. Henry's clinical diagnosis and 
management by laboratory methods. Elsevier. $23^{\text {rd }}$ ed. Iegūts no: https://www-clinicalkeycom.db.rsu.lv/\#!/content/book/3-s2.0-B9780323295680000747 (sk. 26.08.2016).

62. Janda, S., Swiston, J., 2012. Intrapleural fibrinolytic therapy for treatment of adult parapneumonic effusions and empyemas: a systematic review and meta-analysis. Chest. Iegūts no: http://www.sciencedirect.com.db.rsu.lv/science/article/pii/S001236921260001X （sk. 28.08.2016).

63. Jänicke, F., Precht, A., Thomssen, C. et al., 2001. Randomized adjuvant chemotherapy trial in highrisk, lymph node-negative breast cancer patients identified by urokinase-type plasminogen activator and plasminogen activator inhibitor type 1. J. Natl. Cancer Inst. 93: 913-920.

64. Jarvi, O. H., Kunnas, R. J., Laitio, M. T.et al., 1972. The accuracy and significance of cytologic cancer diagnosis of pleural effusions. Acta Cytol. 16: 152-157.

65. Jimenez, D., Diaz, G., Cicero, A. et al., 2005. Etiology and prognostic significance of massive pleural effusions. Respir Med. Iegūts no: http://www.resmedjournal.com/article/S09546111(05)00049-1/fulltext (sk. 13.08.2016.).

66. Jiménez, D., Díaz, G., García-Rull, S. et al., 2006. Routine use of pleural fluid cultures. Are they indicated? Limited yield, minimal impact on treatment decisions. Respir Med. Iegūts no: http://www.sciencedirect.com/science/article/pii/S095461110600093X (sk. 18.08.2016.).

67. Kalaajieh, W.K. 2001. Etiology of exudative pleural effusions in adults in North Lebanon Can Respir J.; 8(2): 93-97.

68. Kalantri, Y., Naik, G., Joshi, S.P., Jain, A., Phatak, S., Chavan, R., Hemvani, N., Chitnis, D.S. 2007. Role of cancer antigen-125 from pleural \& ascitic fluid samples in non malignant conditions Indian J Med Res. Jan;125(1): 25-30.

69. Kao, S.C., Pavlakis, N., Harvie, R. et al. 2010. High blood neutrophil-to-lymphocyte ratio is an indicator of poor prognosis in malignant mesothelioma patients undergoing systemic therapy Clin Cancer Res. Iegūts no: http://clincancerres.aacrjournals.org/content/16/23/5805.long (sk. 05.02.2017.).

70. Kataoka, H., Takafda, S. 2000.The role of thoracic ultrasonography for evalution of patients with decompensated chronic heart failure J Am Coll Cardiol. 35: 1638-1645.

71. Kinnunen, P., Vuolteenaho, O., Ruskoaho, H. 1993. Mechanisms of atrial and brain natriuretic peptide release from rat ventricular myocardium: effect of stretching Endocrinology. 132 (5): 961.

72. Kolditz, M., Halank, M., Schiemank, C.S. et al. 2006.High diagnosticē accuracy of NT-proBNP for cardiac origin of pleural effusions Eur Resp J., 28(1): 144-150.

73. Korczynski, P., Krenke, R., Safianowska, A. et al. 2009. Diagnostic utility of pleural fluid and serum markers in differentiation between malignant and non-malignant pleural effusions Eur J Med Res. Iegūts no: https://www.ncbi.nlm.nih.gov/pmc/articles/PMC3521354/ (sk. 12.08.2016.).

74. Lai-Fook., S. J. 2004. Pleural mechanics and liquid exchange. Physiol Rev. 84: 385-410.

75. Li, H., Huang, L., Tang, H. 2015. Pleural Fluid Carcinoembryonic Antigen as a Biomarker for the Discrimination of Tumor-related Pleural Effusion. Clin Respir J. Iegūts no: I http://onlinelibrary.wiley.com.db.rsu.lv/doi/10.1111/crj.12431/epdf (sk. 04.02.2017.).

76. Li, J., Wu, M. F., Lu, H. W. et al. 2016. Pretreatment serum lactate dehydrogenase is an independent prognostic factor for patients receiving neoadjuvant chemotherapy for locally advanced cervical cancer. Cancer Med. Iegūts no: http://onlinelibrary.wiley.com/doi/10.1002/cam 4.779/full (sk. 07.08.2016).

77. Li, Q., Sun, W., Yuan, D. et al. 2016. Efficacy and safety of recombinant human tumor necrosis factor application for the treatment of malignant pleural effusion caused by lung cancer Thorac Cancer. Iegūts no: https://www.ncbi.nlm.nih.gov/pmc/articles/PMC4718129/ (sk. 31.01.2017.). 
78. Liam, C.K., Lim, K.H., Wong, C.M 2000. Causes of pleural effusion in region with high incidence of tuberculosis Respirology Iegūts no: http://onlinelibrary.wiley.com/wol1/doi/10.1046/j.14401843.2000.00223.x/full (sk. 13.08.2016.).

79. Light, R. W.; Lee, Y. G 2003. Textbook of pleural diseases Edward Arnold (Publishers) Ltd., 553.

80. Light, R.W. 2013.The Light criteria Clinics in Chest Medicine. 34(1). Iegūts no: https://wwwclinicalkey-com.db.rsu.lv/\#!/content/journal/1-s2.0-S0272523112001244 (sk. 17.08.2016.).

81. Light, R.W., MacGregor, M.I., Luchsinger, P.C. et al. 1972. Pleural effusions: the diagnostic separation of transudates and exudates. Ann Intern Med. 77: 507-514.

82. Light, R.W., Hamm, H. 1997. Malignant pleural effusion: would the real cause please stand up? Eur Respir J. Iegūts no: http://erj.ersjournals.com/content/10/8/1701.long (sk. 10.08.2016.).

83. Lin, F.C., Chen, Y.C., Chen, F.J., Chang, S.C. 2005. Cytokines and fibrinolytic enzymes in tuberculos and parapneumonic effusions. Clin Immunol. Aug;116(2): 166-173.

84. Loddenkemper, R., Antony, V. B. 2002. Pleural diseases. European Respiratory Society Journals Ltd. 326.

85. Loddenkemper, R., Janssen, J.P. 2016. Thoracoscopy . In: Broaddus, V.C., Mason, R.J., Ernst, J.D. et al., Murray and Nadels Textbook of Respiratory Medicine, 6th ed. Elsevier. Iegūts no: https://www-clinicalkey-com.db.rsu.lv/\#!/content/book/3-s2.0-B9781455733835000245 17.08.2016.).

86. Long, A.C., O'Neal, H.R. Jr, Peng, S. et.al. 2010. Comparison of pleural fluid N-Terminal ProBrain Natriuretic Peptide and Brain Natriuretic-32 Peptide Levels Chest. 137(6): 1369-1374.

87. Long, A. C., O'Neal, H. R. Jr., Peng, S. et.al. 2010. Comparison of pleural fluid N-Terminal ProBrain Natriuretic Peptide and Brain Natriuretic-32 Peptide Levels. Chest. 137(6): 1369-1374.

88. Lu, X.G., Mao, J.S., Tong, J.F. et al. 2007. Fibrinolytic characteristics and their significance in malignant, tuberculous and cirrhotic pleural and ascitic fluids Int J Lab Hematol. Apr 29(2): 132138.

89. Ma, J., Zhao, Y., Wang, Y. et al. 2013. Tumor marker levels in patients aged 85 years and older with chronic heart failure. Eur J Intern Med. Iegūts no: http://ac.elscdn.com.db.rsu.lv/S0953620513001052/1-s2.0-S0953620513001052-main.pdf?_tid=9cc65c386c36-11e6-9463-00000aacb35e\&acdnat=1472289429_c50887a835100dec7a0314e914e20d87 (sk. 27.08.2016.).

90. Marel, M., Zrustova, M., Stasny, B. et al. 1993. The incidence of pleural effusion in a well-defined region: epidemiologic study in central Bohemia Chest. Iegūts no: http://www.sciencedirect.com/science/article/pii/S0012369215422974 (sk. 09.08.2016.).

91. Marinho, F. C. A., Vargas, F. S., Fabri Jr. et.al. 2011. Clinical usefulness of B-type natriuretic peptide in the diagnosis of pleural effusions due to heart failure Respirology. 16 (3): 495-499.

92. Maskell, N.A., Davies, C.W., Nunn, A. et al. 2005. First Multicenter Intrapleural Sepsis Trial (MIST1) Group.. U.K. Controlled trial of intrapleural streptokinase for pleural infection $N$ Engl J Med. Iegūts no: http://www.nejm.org/doi/full/10.1056/NEJMoa042473 (sk. 31.01.2017.).

93. Maskell, N.A., Light, R.W.2016. Pleural Infections. In: Broaddus, V.C., Mason, R.J., Ernst, J.D. et al. Murray and Nadels Textbook of Respiratory Medicine 6th ed.Elsevie., Iegūts no: https://wwwclinicalkey-com.db.rsu.lv/\#!/content/book/3-s2.0-B9781455733835000804 (sk. 14.08.2016.).

94. Mccool, F.D. 2015. Pleural effusions. In: Goldman, B. L., Shafer, A. I. Disease of the diafragma, chest wall, pleura and mediastinum 25th ed. Goldman Cecil Medicine. Elsevier. Iegūts no: https://www-clinicalkey-com.db.rsu.lv/\#!/topic/pleural\%20effusion?scrollTo=\%23hl0000841 (sk. 09.08.2016.).

95. McLaughlin, R.F., Tyler, W.S., Canada, R.O. 1961. A study of the subgross pulmonary anatomy of various mammals. Am J Anat 108: 149-159. 
96. Miao, L., Lu, Y., Xu, Y. et al. 2016. PD-L1 and c-MET expression and survival in patients with small cell lung cancer. Oncotarget. Iegūts no: http://www.impactjournals.com/oncotarget/index.p hp?journal=oncotarget\&page $=$ article \&op=view\&path\%5B $\% 5 \mathrm{D}=9765 \&$ path $\% 5 \mathrm{~B} \% 5 \mathrm{D}=30612$ (sk. 07.08.2016.).

97. Mignatti, P. and Rifkin, D.B. 1993. Biology and biochemistry of proteinases in tumor invasion. Physiol. Rev. 73: 161-195.

98. Mishra, E.K., Corcoran, J.P., Hallifax, R.J. et al. 2015. Defining the minimal important difference for the visual analogue scale assessing dyspnea in patients with malignant pleural effusions. PLoS ONE. 10(4) Iegūts no: http://journals.plos.org/plosone/article?id=10.1371/journal.pone.0123798 (sk. 18.08.2016.).

99. Mohanty, S., Kapil, A., Das, B.K. 2007. Bacteriology of parapneumonic pleural effusions in an Indian hospital Trop Doct. Iegūts no: https://www.ncbi.nlm.nih.gov/pubmed/17988487 (sk. 07.02.2017.).

100. Montanaro, F., Bray, F., Gennaro, V. et al. 2003. Pleural mesothelioma incidence in Europe: evidence of some deceleration in the increasing trends. Cancer Causes Control. 14(8): 791-803.

101. Montes, J.F., Garcia-Valero, J., Ferrer, J. 2006. Evidence of innervation in talc-induced pleural adhesions. Chest. 130: 702-709.

102. Nguyen, A.H., Miller, E.J., Wichman, C.S. et al. 2015. Diagnostic value of tumor antigens in malignant pleural effusion: a meta-analysis. Transl Res. Iegūts no: http://ac.elscdn.com.db.rsu.lv/S1931524415001139/1-s2.0-S1931524415001139-main.pdf?_tid=8977bfe86bcb-11e6-9ccc-00000aacb362\&acdnat=1472243441_0a8b4c17944cbb73f920a1250b0fb88e（sk. 26.08.2016.).

103. Nicholson, B.D., Shinkins, B., Pathiraja I. et al. 2015. CEA levels for detecting recurrent colorectal cancer. The Cochrane Library. Iegūts no: http://www.cochrane.org/CD011134/COLOCA_detecti ng-recurrent-colorectal-cancer-testing-blood-carcino-embryonic-antigen-cea (sk. 08.08.2016.).

104. Nie, W., Liu, Y., Ye, J. et al. 2014. Efficacy of intrapleural instillation of fibrinolytics for treating pleural empyema and parapneumonic effusion: a meta-analysis of randomized control trials.Clin Respir J. Iegūts no: http://onlinelibrary.wiley.com/doi/10.1111/crj.12068/full (sk. 28.08.2016).

105. Noppen, M., De Waele, M., Li, R. et al. 2000. Volume and cellular content of normal pleural fluid in humans examined by pleural lavage. Am J Respir Crit Care Med Iegūts no: http://www.atsjournals.org/doi/full/10.1164/ajrccm.162.3.9910050\#.V7X3WPmLTIU （sk. 18.08.2016.).

106. Núñez, J., Núñez, E., Consuegra, L. et al. 2007. Carbohydrate antigen 125: an emerging prognostic risk factor in acute heart failure? Heart. Iegūts no: https://www.ncbi.nlm.nih.gov/pmc/articles/PMC1955175/ (sk. 27.08.2016.).

107. Oken, M.M., Creech, R.H., Tormey, T.D et al. 1982. Toxicity and Response criteria of Eastern Cooperative Oncology Group. Am J Clin Oncol., 5(6): 649-656.

108. Oldmixon, E.G., Hoppin, F.G. 1982. Morphometric quantification of connective tissue in pleura and alveolar parenchyma. Fed Proc. 41: 1127.

109. Pai, M., Flores, L.L., Hubbard, A. et al: 2004. Nucleic acid amplification tests in the diagnosis of tuberculous pleuritis: a systematic review and meta-analysis. BMC Infect Dis. Iegūts no: https://www.ncbi.nlm.nih.gov/pmc/articles/PMC387423/ (sk. 18.08.2016.).

110. Pamies, R.J., Crawford, D.R. 1996. Tumor markers. An update. Med Clin North Am. 80:185-199.

111. Passardi, A., Scarpi, E., Tamberi, S. et al. 2015. Impact of Pre-Treatment Lactate Dehydrogenase Levels on Prognosis and Bevacizumab Efficacy in Patients with Metastatic Colorectal Cancer. PLoS One. Iegūts no: http://www.ncbi.nlm.nih.gov/pmc/articles/PMC4526665/ (sk.07.08.2016.). 
112. Penz, E., Watt, K.N., Hergott, C.A. et al. 2017. Management of malignant pleural effusion: challenges and solutions. Cancer Manag Res. Iegūts no: https://www.ncbi.nlm.nih.gov/pmc/articles/PMC5491570/ (sk. 19.11.2017)

113. Philip-Joët, F., Alessi, M.-C., Philip-Joët, C. et al. 1995. Fibrinolytic and inflammatory processes in pleural effusions Eur Respir J. Iegūts no: http://erj.ersjournals.com/content/erj/8/8/1352.full.pdf (skat. 27.08.2016.).

114. Pintelon, I. 2007. Sensory receptors in the visceral pleura. Am J Respir Cell Mol Biol. 36: 541-551.

115. Porcel, J. 2007. Analysis of pleural effusions in acute pulmonary embolism: radiological and pleural fluid data from 230 patients. Respirology. 12: 234-230.

116. Porcel, J.M., Esquerda, A., Bielsa, S. 2010. Diagnostic performance of adenosine deaminase activity in pleural fluid: a single-center experience with over 2100 consecutive patients. Eur $J$ Intern Med. 21: 419-423.

117. Porcel, J.M., Vives, M., Cao, G. et al. 2004. Measurement of pro-brain nariuretic peptide in pleural fluid for the diagnosis of pleural effusions due to heart failure. Am J Med. Iegūts no: http://www.amjmed.com/article/S0002-9343(03)00716-2/fulltext (sk. 17.08.2016.).

118. Porcel, J. M., Chorda, J., Cao, G. et.al. 2007. Comparing serum and pleural fluid pro-brain natriuretic peptide (NT-proBNP) levels with pleural-to-serum albumin gradient for the identification of cardiac effusions misclassified by Light's criteria. Respirology, 12 (5): 654.

119. Prina, E., Torres, A., Carvalho, C.R. 2014. Lung ultrasound in the evaluation of pleural effusion. $J$ Bras Pneumol. Iegūts no: http://www.scielo.br/pdf/jbpneu/v40n1/1806-3713-jbpneu-40-0100001.pdf (sk. 09.08.2016.).

120. Psallidas, I., Kolomenidis, I., Porcel, J.M. et al. 2016. Malignant pleural effusion: from bench to bedside. Eur Respir Rev. Iegūts no: http://err.ersjournals.com/content/25/140/189.long (sk. 10.08.2016.).

121. Rahman, N.M., Ali, N.J., Brown, G. et al. 2010. Local anaesthetic thoracoscopy: British Thoracic Society Pleural Disease Guideline. Thorax. 65: Suppl 2 Iegūts no: http://thorax.bmj.com/content/65/Suppl_2/ii54.full (sk. 10.08.2016.)

122. Rahman, N.M., Maskell, N.A., West, A. et al. 2011. Intrapleural use of tissue plasminogen activator and DNase in Pleural infection. N Eng J Med. Iegūts no: http://www.nejm.org/doi/full/10.1056/N EJMoa1012740\#t=articleBackgroart (sk. 28.08.2016).

123. Raptopoulos, V., Davis, L. M., Lee, G. et al. 1991. Factors affecting the development of pneumothorax associated with thoracentesis. AJR Am J Roentgenol. Iegūts no: http://www.ajronline.org/doi/abs/10.2214/ajr.156.5.2017951 (sk. 09.08.2016).

124. Rashna, D. B., Victoria, A. P. 2008. Plasminogen activator inhibitor-1: The double-edged sword in apoptosis. Thromb Haemost. Dec;100(6):1029-1036.

125. Roberts, M.E., Neville, E., Berrisford, R.G. et al. 2010. BTS Pleural Disease Guidline Group. Management of a malignant pleural effusion: British Thoracic Society Pleural Disease Guidline 2010. Thorax. Iegūts no: http://thorax.bmj.com/content/65/Suppl_2/ii32/T1.expansion.html (sk. 12.08.2016.).

126. Rodriguez-Panadero, F., Janssen, J.P., Astoul, P. 2006. Thoracoscopy: general overview and place in the diagnosis and management of pleural effusion. Eur Respir J. Iegūts no: http://erj.ersjournals.com/content/28/2/409 (sk. 17.08.2016.).

127. Rodriguez-Panadero, F., Segado, A., Martin Juan, J. et al. 1995. Failure of talc pleurodesis is associated with increased pleural fibrinolysis. Am J Respir Crit Care Med. 151(3 Pt 1): 785-790.

128. Rudzītis, K. 2005. Terminologia Medica. Strautiņ̌̌, I., Stradiņ̌̌, J., Apinis, P., Senkāns, A. 3. papildinātais izdevums. Rīga: Alise-T. 599; 660; 973. 
129. Ruhl, T.S., Good, J.L. 2011. Thoracocentesis In: Pfenniger, J.L. Pfenniger and Fowler's proceedures for primary care. 3rd ed. Saunders. Iegūts no: https://www-clinicalkeycom.db.rsu.lv/\#!/content/book/3-s2.0-B9780323052672000959 (sk. 16.08.2016.).

130. Sahn, A.S. 2003. Approach to the patient with a pleural effusion In: Light, R. W., Lee, Y. G. ed. Textbook of pleural diseases. London: Edward Arnold (Publishers) Ltd. 183-190.

131. Sahn, S.A. 1997. Pleural diseases related to metastatic malignancies. Eur Respir J. 10. Iegūts no: http://erj.ersjournals.com/content/erj/10/8/1907.full.pdf (sk. 08.08.2016.).

132. Sahn, S.A. 1997. Pleural diseases related to metastatic malignancies. Eur Respir J. Iegūts no: http://erj.ersjournals.com/content/erj/10/8/1907.full.pdf (sk.12.082016.).

133. Sakr, L., Maldonado ,F., Greillier, L. et al. 2011. Thoracoscopic assessment of pleural tumor burden in patients with malignant pleural effusion: prognostic and therapeutic implications. $J$ Thorac Oncol. Iegūts no: http://www.jto.org/article/S1556-0864(15)32216-4/fulltext (sk. 10.08.2016.).

134. Sallach, S.M., Sallach, J.A., Vasquez, E. 2002.Volume of pleural fluid required for diagnosis of pleural malignancy. Chest. Iegūts no: www.sciencedirect.com/science/article/pii/S001236921550 8052 (sk. 07.02.2017.).

135. Sanford, D.E., Goedegebuure, P.S., Eberlein, T.J. 2016. Tumor biology and tumor markers In: Townsend, C.M., Beuchhamp, R.D., Evers, B.M. et al. Sabiston textbook of surgery. Elsevier 20th ed. Iegūts no: https://www-clinicalkey-com.db.rsu.lv/\#!/content/book/3-s2.0B978032329987900028X?scrollTo=\%23hl0001093 (sk. 26.08.2016.).

136. Seely, J. M., Ayyappan, A. P. 2008. Pleural effusion. In: Muller, N. M., Silva, I. S. Imaging of the chest. 1st ed. Saunders. Iegūts no: https://www-clinicalkey-com.db.rsu.lv/\#!/content/book/3-s2.0B9781416040484500933?scrollTo=\%23top (sk. 09.08.2016.).

137. Septimus, E.J. 2015. Pleural effusion and empiema In: Bennett, J.E. Mandell, Douglas, and Bennett's Principles ad Practice of Infectious Diseases 8th ed. Saunders. Iegūts no: https://wwwclinicalkey-com.db.rsu.lv/\#!/content/book/3-s2.0-B978032340161600070X (sk. 14.08.2016.).

138. Septimus, E.J. 2015. Pleural effusion and empiema In: Bennet, J.E. ed. Mandell, Douglas, and Bennett's Principles and Practice of Infectious Diseases . Elsevier. Iegūts no: https://wwwclinicalkey-com.db.rsu.lv/\#!/content/book/3-s2.0

B978032340161600070X?scrollTo=\%23h10000306 (sk. 31.01.2017.).

139. Sharma, S. 2009. Tumor markers in clinical practice: General principles and guidelines. Indian J Med Paediatr Oncol. Iegūts no: http://www.ncbi.nlm.nih.gov/pmc/articles/PMC2902207/ (sk. 26.08.2016.).

140. Sharma, S.K., Bhat, S., Chandel, V.et al. 2015. Diagnostic utility of serum and pleural fluid carcinoembryonic antigen, and cytokeratin 19 fragments in patients with effusion from nonsmall cell lung cancer. J Carcinog. Iegūts no: https://www.ncbi.nlm.nih.gov/pmc/articles/PMC4736054 /\#ref8 (sk. 26.08.2016.).

141. Shirota, C., Uchida, H. 2015. Initial treatment of septated parapneumonic empyema with drainage plus fibrinolytic agents is equally effective as video-assisted thoracoscopic surgery, and is suitable as first- line therapy. Transl Pediatr. Iegūts no: https://www.ncbi.nlm.nih.gov/pmc/articles/PMC4 729070/ (sk. 28.08.2016).

142. Slimību profilakses un kontroles centrs, 2015. Veselībs aprūpes statistika. Iegūts no: https://www.spkc.gov.lv/lv/statistika-un-petijumi/statistika/veselibas-aprupes-statistika1/get/nid/1 (sk. 31.01.2017.).

143. Skok, K., Hladnik, G., Grm, A. Et al. 2019. Malignant Pleural Effusion and Its Current Management: A Review. Medicina (Kaunas).Iegūts no: https://www.ncbi.nlm.nih.gov/pmc/articles/PMC6723530/ (sk.03.05.2020.)

144. Son, S.M., Han, H.S., An, J.Y. et al. 2015. Diagnostic performance of CD66c in lung adenocarcinoma-associated malignant pleural effusion: comparison with CEA, CA 19-9, and 
CYFRA 21- 1. Pathology. Iegūts no: https://www.clinicalkey- com.db.rsu.lv/service/content/pdf/ watermarked/1-s2.0-S0031302516301416.pdf?locale=en_US (sk. 04.02.2017.).

145. Stark, P. 2015. Imaging of pulmonary disease. In: Goldman, B. L., Schafer, A.I. Goldman - Cecil Medicine 25th ed. Elsevier, Iegūts no: https://www-clinicalkey-com.db.rsu.lv/\#!/content/3-s2.0B9781455750177000842? scrollTo=\%23c00084 (sk. 09.08.2016.).

146. Stathopoulos, G.T., Kalomenidis, I. 2012. Malignant pleural effusion: tumor-host interactions unleashed. Am J Respir Crit Care Med. Iegūts no: http://www.atsjournals.org/doi/full/10.1164/rcc m.201203-0465PP\#.V6riGfmLTIU (skatîts 10.08.2016.).

147. Stein, P.D., Henry, J.W. 1997. Clinical characteristics of patients with acute pulmonary embolism stratified according their presenting syndromes. Chest. 112: 974-979.

148. Swiderek, J., Marcos, S., Donthireddy, V. et al. 2010. Prospective study to determine the volume of pleural fluid required to diagnose malignancy. Chest. 137(1): 68-73.

149. Taghizadeh, N. , Fortin, M. , Tremblay, A. 2016. USA hospitalizations for malignant pleural effusions: data from the 2012 National Inpatient Sample. Chest. 151(4): 845-854.

150. Tassi, G.F., Marchetti, GP.2008. Peural disease: historic perspective. In: Light, R.W. , Lee, Y.C.G. ed. Pleural disese textbook. CRC Press. $1-8$.

151. Teibe,U. 2007. Biologiskā statistika: mācību materiāls. Rīga, LU Akadēmiskais apgāds.

152. Thomas, R., Cheah, H.M., Creaney, J. et al. 2016. Longitudinal Measurement of Pleural Fluid Biochemistry and Cytokines in Malignant Pleural Effusion. Chest. Iegūts no: http://www.sciencedirect.com/science/article/pii/S0012369216004554 (sk. 31.01.2017.).

153. Thomas, S.C., Davidson, L.R., McKean, M.E. 2011. An investigation of adequate volume for the diagnosis of malignancy in pleural fluids. Cytopathology. Iegūts no: http://eds.a.ebscohost.com.db.rsu.lv/eds/pdfviewer/pdfviewer?vid=2\&sid=f5d5ea3a-2fe8-4986a876-61d662b5c8f2\%40sessionmgr4010\&hid=4210 (sk. 07.02.2017.).

154. Timmermann, C. 2013. 'Just give me the best quality of life questionnaire': the Karnofsky scale and the history of quality of life measurements in cancer trials. Chronic Illn. Iegūts no: https://www.ncbi.nlm.nih.gov/pmc/articles/PMC3837542/ (sk. 28.08.2016.).

155. Tomasson, K., Gudmundsson, G., Briem, H. et al. 2016. Malignant mesothelioma incidence by nation-wide cancer registry: a population based study. $J$ Occup. Med. Iegūts no: http://www.ncbi.nlm.nih.gov/pmc/articles/PMC4960893/ (sk. 13.08.2016.).

156. Tozzoli, R., Basso, S.M., D'Aurizio, F. et al. 2016. Evaluation of predictive value of pleural CEA in patients with pleural effusions and histological findings: A prospective study and literature review. Clin Biochem. Iegūts no: http://ac.els-cdn.com.db.rsu.lv/S0009912016301850/1-s2.0S0009912016301850-main.pdf?_tid=38c09e06-6b96-11e6-b098-

00000aacb361\&acdnat=1472220542_e68bbfaf31e7d4a430c30a0dd8a2fddf (sk. 26.08.2016.).

157. Tuna A., Solak O., Cetinkaya E, et al. 2004. Lactate dehirogenase levels predict pulmonary morbidity after lung resection for non-small lung cancer. Eur J Cardiothoracic Surg. 26: 483-487.

158. Valdes, L., Alvarez, D., Valle, J.M. et al. 1996. The aetiology of pleural effusions in an area with high incidence of tuberculosis. Chest. Iegūts no: http://www.sciencedirect.com/science/article/pii/ S0012369215455461 (sk. 09.08.2016.).

159. Valsecchi, A., Arondi, S., Marchetti, G. 2016. Medical thoracoscopy: Analysis on diagnostic yield through 30 years of experience. Ann Thorac Med. Iegūts no: https://www.ncbi.nlm.nih.gov/pmc/articles/PMC4966219/?report=classic (sk. 17.08.2016.).

160. Vaz, M.A., Teixeira, L.R., Vargas, F.S. et al. 2001. Relationship between pleural fluid and serum cholesterol levels. Chest. 119(1): 204-210.

161. Verma, A., Phua, C.K., Sim, W.Y. et al. 2016. Abisheganaden J. Pleural LDH as a prognostic marker in adenocarcinoma lung with malignant pleural effusion. Medicine (Baltimore). Iegūts no: 
http://journals.lww.com/md-Journal/Fulltext/2016/06280/Pleural_LDH_as_a_prognostic_marker _in.32.aspx (sk. 07.08.2016.).

162. Villena Garrido, V., Cases, Viedma, E., Fernández Villar, A. et al. 2014. Recommendations of diagnosis and treatment of pleural effusion. Update Arch Bronconeumol. Iegūts no: http://www.archbronconeumol.org/index.php?p=watermark\&idApp=UINPBA00003Z\&piiItem= S1579212914001293\&origen=bronco\&web=bronco\&urlApp=http://www.archbronconeumol.org \&estadoItem=S300\&idiomaItem=en (sk. 28.07.2016.).

163. Villena Garrido. V., Lopez Encuentra. A., Echave-Sustaeta. J. et al. 2002. Estudio prospective de 1000 pacientes consecutivos con derrame pleural. Etiologia del derrame y characteristicasnde los pacientes. [Prospective study of 1000 consecutive patients with pleural effusion. Etiology of the effusion and characteristics of the patients.]. Arch Bronconeumonol. 2002; 38 (1): 21-26.

164. Wang, D., Zhang, M., Gao, X. et al. 2016. Prognostic Value of Baseline 18F-FDG PET/CT Functional Parameters in Patients with Advanced Lung Adenocarcinoma Stratified by EGFR Mutation Status. PLoS One. Iegūts no: http://www.ncbi.nlm.nih.gov/pmc/articles/PMC4918955/ (sk. 07.08.2016.).

165. Weinberger, S.E., Cockrill, B.A., Mandel, J. 2013. Pleural Disease: Principles of Pulmonary Medicine. 6th ed. Saunders, imprint of Elsevier Inc. Iegüts no: https://www-clinicalkeycom.db.rsu.lv/\#!/content/book/3-s2.0-B9781455725328000153 (sk. 07.08.2016.).

166. Wiener-Kronish, J. P., Broaddus, V. C. 1993. Interrelationship of pleural and pulmonary interstitial liquid .Annu Rev Physiol. 55: 209-226.

167. Wu, H., Khosla, R., Rohatgi, P.K. et al. 2017. The minimum volume of pleural fluid required to diagnose malignant pleural effusion: A etrospective study. Lung India. Iegūts no: https://www.ncbi.nlm.nih.gov/pmc/articles/PMC5234196/ (sk. 07.02.2017.).

168. Xia, H., Wang, X.J., Zhou, Q. et al. 2014. Efficacy and safety of talc pleurodesis for malignant pleural effusion: a meta- analysis. PLosOne. Iegūts no: https://www.ncbi.nlm.nih.gov/pmc/article s/PMC3903610/ (s. 28.08.2016.).

169. Xu, C.H., Zhan, P., Yu, L.K.2014. Diagnostic value of pleural interleukin 17 and carcinoembryonic antigen in lung cancer patients with malignant pleural effusions. Tumour Biol. Iegūts no: http://eds.b.ebscohost.com.db.rsu.lv/eds/pdfviewer/pdfviewer?vid=5\&sis=96ab283a-378d-4d7d80d2-80be6f009359\%40sessionmgr101\&hid=119 (sk. 04.02.2017.).

170. Xu, C.H., Hao, K.K., Yu, L.K., Zhang, X.W. 2015. Diagnostic value of soluble receptor-binding cancer antigen expressed on SiSo cells and carcinoembryonic antigen in malignant pleural effusion in patients with lung cancer. Asia Pac J Clin Oncol. Mar;11(1):28-33.

171. Zablockis R., Nargela R. 2002. Diagnostic value of pleural fluid citologic examination. Medicina (Kaunas). 38(12): 1171-1178.

172. Zamboni, M.M., Silva, C.T. Jr, Baretta, R. et al. 2015. Important prognostic factors for survival in patients with malignant pleural effusion. BMC Pulm Med. Iegūts no: http://bmcpulmmed.biomedcentral.com/articles/10.1186/s12890-015-0025-z (sk. 13.08.2016.).

173. Zhang, X.K., Zhang, Z.L., Lu, X. et al. 2016. Prognostic Significance of Preoperative Serum Lactate Dehydrogenase in Upper Urinary Tract Urothelial Carcinoma. Clin Genitourin Cancer. Iegūts no: http://www.clinical-genitourinary-cancer.com/article/S1558-7673(16)30003-9/fulltext (sk.07.08.2016).

174. Zissimopoulos, A., Stellos, K., Permenopoulou, V. et al. 2007. The importance of the tumor marker CYFRA 21-1 in patients with lung cancer after surgery or chemotherapy. Hell J Nucl Med. 10: 62-66. 


\section{PUBLIKĀCIJAS PAR PĒTĪJUMA TĒMU}

\section{Zinātniskie raksti}

1. Dubava, D. (Žentiņa), Valdmane, A., Vikmane, I., Lejnieks, A., 2011. Pleiras izsvīduma diagnostika Rīgas Austrumu klīniskās universitāte slimnīcas stacionārā "Gaiḷezers". Rīgas Stradiņa universitātes Zinātniskie raksti. (1); 59.-70. lpp.

2. Dubava, D. (Žentiņa), Tirzīte, M., Krams, A., Lejnieks, A., 2012. Audzēja marḳieri pleiras šķidrumā. Rīgas Stradiṇa universitātes Zinātniskie raksti. (1); 65.-71. lpp.

3. Žentiņa, D., Bočins, R., Stuḳēna, I., Krams, A., Lejnieks, A., 2013. Vai BNP līmenis serumā ir pietiekami jutīgs diagnostisks marķieris pacientiem ar kardiālu hidrotoraksu? Rīgas Stradiṇa universitātes Zinātniskie raksti. (1); 75.-81. lpp.

4. Zentina, D., Stukena, I., Grinberga, S., Krams, A., Lejnieks, A. 2016. Diagnostic Value of tumor markers $\mathrm{Ca} 125$ and CEA in the diagnostics of malignant pleural fluids. Proceedings of the Latvian Academy of Sciences, Section B, (70). 2(701): 41-46. DOI: 10.1515/prolas-2016-0008.

5. Zentina,D., Stukena, I., Krams, A., Lejnieks, A. 2019. PAI-1 Level Differences in Malignant Plural Effusion, Parapneumonic Pleuritis, and Cardiac Hydrothorax. Medicina (Kaunas). 55(9). pii: E567. doi: 10.3390/medicina55090567. PubMed PMID: 31487930.

\section{Tēzes starptautiskās konferencēs}

1. Dubava, D. (Žentiṇa), Tirzite, M., Stukena, I., Krams, A., Lejnieks, A. Potential role of antioxidant status ratio in differential diagnosis of pleural effusion European Respiratory Society Annual Congress. Barcelona, 2013. (Poster Discussion).

\section{Tēzes konferencēs Latvijā}

1. Dubava, D. (Zentina), Krams, A., Lejnieks, A. Leikocītu procentuālā sastāva nozīme maligna pleiras eksudāta diagnostikā. Rīgas Stradiṇa universitātes Zinātniskās konferences tēzes. Rīga, 2012. 254 lpp. (Stenda referāts).

2. Žentiņa, D., Tirzīte, M., Stuķēna, I., Krams, A., Lejnieks, A. 2013.Totālā antioksidantu statusa noteikšanas prognostiskas izmantošanas iespējas pleiras šḳidrumu diagnostikā. 
Rīgas Stradinạa Universitātes Zinātniskās konferences tēzes. Rīga, 2013. 278. lpp. (Stenda referāts).

3. Dubava (Žentiņa), D., Bočins, R., Stuķēna, I., Krams, A., Lejnieks, A. B-tipa nātrijurētiskais peptīds asins serumā un pleiras punktātā - papildu kritērijs pleiras šķidrumu diferenciālajā diagnostikā. Rīgas Stradiṇa universitātes Zinātniskās konferences tēzes. Rīga, 2013. 40. lpp. (Mutiska uzstāšanās).

4. Dubava (Žentiņa), D., Stuḳēna, I., Krams, A., Lejnieks, A. Vai pēc seruma iekaisuma marḳieriem - laktātdehidrogenāzes un C reaktīvā olbaltuma - var spriest par pleiras šķidruma etiolog̣iju? Rīgas Stradiṇa universitātes Zinātniskās konferences tēzes. Rīga, 2014. 273. 1pp. (Stenda referāts).

5. Vasiḷjeva, G., Stuķēna, I., Žentiņa, D., Krūmiņa, A. Sliktas prognozes riska faktori pacientiem ar sadzīvē iegūtu pneimoniju. Rīgas Stradiṇa universitātes Zinātniskās konferences tēzes. Rīga, 2014. 151. lpp. (Stenda referāts).

6. Žentiņa, D., Bočins, R., Stuḳēna, I., Krams, A., Lejnieks, A. 2015. Plazminogēna aktivatora inhibitors - 1 dažādas etioloǵijas pleiras šķidrumā. Rīgas Stradiṇa universitātes Zinātniskās tēzes. Rīga, 2015. 269. lpp. (Stenda referāts). 


\section{PATEICĪBAS}

Visdziḷākā pateicība mana promocijas darba vadītājam Dr. med. Profesoram Aivaram Lejniekam par sniegtajiem padomiem, pacietību, neatlaidību un pamudinājumu izstrādāt šo darbu.

Sirsnīgi pateicos mana darba vadītājam asociētajam profesoram Alvilam Kramam.

Sirsnīgs paldies manai kolēǵei, draudzenei un padomdevējai $\mathrm{Dr}$. med. asociētai profesorei Ingai Stuḳēnai par nenovērtējamo atbalstu darba tapšanā.

Paldies Dr. Agnesei Valdmanei-Zviedrītei par palīdzību pētījuma datu apkopošanā.

Paldies maniem lieliskajiem kolēgiem Paula Stradiṇa Klīniskajā universitātes slimnīcā par atbalstu un iedrošinājumu brīžos, kad pietrūka apṇēmības.

Paldies Roche akadēmijai par finansiālo atbalstu.

Visbeidzot - paldies manai ǵimenei, kura mani atbalstīja un ir mans galvenais motivators, lai sasniegtu jaunus mērķus. 
PIELIKUMI 
Rīga, Dzirciema iela 16, LV-1007 Tel.67409137

\begin{tabular}{lll}
\hline Komitejas sastāvs & Kvalifikācija & Nodarbošanās \\
\hline 1. Asoc. prof. Olafs Brūvers & Dr.miss. & teologs \\
2. Docente Santa Purviña & Dr.med. & farmakologs \\
3. Asoc. prof. Voldemārs Arnis & Dr.biol. & rehabilitologs \\
4. Profesore Regīna Kleina & Dr.med. & patanatoms
\end{tabular}

Pieteikuma iesniedzējs: Dace Dubava

RSU, Doktorantūras nodal̦a

Pētījuma nosaukums: Bioķīmisko un onkolog̣isko marķieru diagnostiskā un prognostiskā nozīme malignu pleiras eksudātu gadījumos.

Iesniegšanas datums: 10.09.2010.

Pētījuma protokols:

(X) Pētījuma veids:

(X) Pētījuma populācija: RAKUS 2. nodal̦as pacienti ar pleirītiem

(X) Informācija par pētījumu:

(X) Piekrišana dalībai pētījumā:

Citi dokumenti:

1. Aț̣auja pētījuma veikšanai no RAKUS ,, Gaiḷezera” klīnikas

2. Darba autores CV

Lēmums: piekrist biomedicīniskajam pētījumam

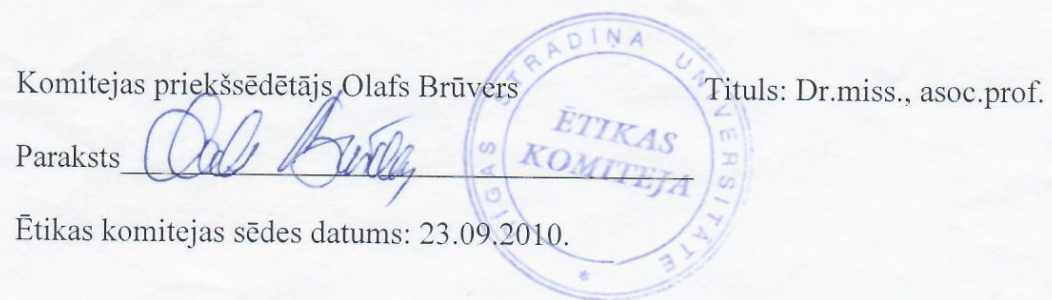

